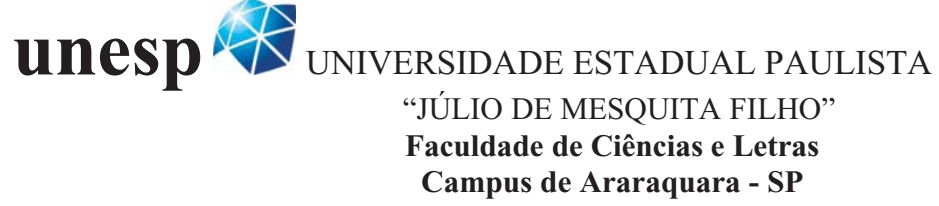

PATRICIA ORMASTRONI IAGALLO

\title{
O TEMPO E A LINGUAGEM
}

\author{
ARARAQUARA - S.P. \\ 2010
}




\section{O TEMPO E A LINGUAGEM}

Dissertação de Mestrado apresentada ao Programa de Pós-Graduação em Linguística e Língua Portuguesa da Faculdade de Ciências e Letras da Universidade Estadual Paulista "Júlio de Mesquita Filho" - UNESP, Câmpus de Araraquara, visando à obtenção do título de Mestre em Linguística e Língua Portuguesa.

Linha de Pesquisa: Análise Fonológica, Morfossintática, Semântica e Pragmática.

Orientador: Prof. Dr. Luiz Carlos Cagliari

Bolsa: $\mathrm{CNPq}$

ARARAQUARA - S.P.

2010 


\section{O TEMPO E A LINGUAGEM}

Dissertação de Mestrado apresentada ao Programa de Pós-Graduação em Linguística e Língua Portuguesa da Faculdade de Ciências e Letras da Universidade Estadual Paulista "Júlio de Mesquita Filho" - UNESP, Câmpus de Araraquara, visando à obtenção do título de Mestre em Linguística e Língua Portuguesa.

Análise Fonológica, Morfossintática, Semântica e Pragmática.

\section{$\mathrm{CNPq}$}

Data de aprovação: 11/05/2010

MEMBROS COMPONENTES DA BANCA EXAMINADORA:

Presidente e Orientador: Prof. Dr. Luiz Carlos Cagliari

UNESP/FCL/Araraquara.

Membro Titular: Prof. Dr. Antônio Suárez Abreu

UNESP/FCL/Araraquara.

Membro Titular: Prof. Dr. Marco Antônio de Oliveira

PUC/Minas/Belo Horizonte.

Local: Universidade Estadual Paulista

Faculdade de Ciências e Letras

UNESP - Campus de Araraquara 
Ao prof. Cagliari, que me instigou a curiosidade, com a sua própria, sobre o tempo linguístico. 


\section{AGRADECIMENTOS}

Ao Prof. Dr. Antônio Suárez Abreu, ao Prof. Dr. Arnaldo Cortina e à Profa. Dra. Marília Blundi Onofre, que acompanharam a construção deste trabalho, contribuindo com suas valiosas leituras, e ao Prof. Dr. Marco Antonio de Oliveira, pela generosidade de seus comentários. O texto desta Dissertação se deve, em parte, a eles, sem que lhes caiba nenhuma responsabilidade pelas deficiências que o conteúdo possa apresentar.

Ao Prof. Dr. Luiz Carlos Cagliari, pela enorme paciência, pela confiança, e pelo acompanhamento seguro.

A todos os professores vinculados ao Programa de Pós-Graduação em Linguística e Língua Portuguesa da Unesp de Araraquara, pelo profissionalismo com que se esforçam para manter o Programa com excelente qualidade, pois, sem eles, muitos alunos não teriam a oportunidade de estudar com bolsas, como a do CNPq, que financiou, em parte, a realização deste trabalho.

Agradeço a toda minha família... à tia Cleide, pelo incentivo; à tia Dedi pelos sábios conselhos; aos meus avós, pela compreensão dos domingos ausentes, ao meu pai, sempre disposto a me ajudar no que fosse preciso; à minha irmã, Priscila, pelo carinho; e à minha mãe, que encucou-me a vaidade de ser Mestre, desde quando eu era pequena.

Ao Emerson, sempre disposto (e com muita paciência) para me ouvir e testar minhas intuições com o seu valioso conhecimento de literatura.

À Di, Conrado, Pedro, Natty, Lulu, Márcia, Dri, Pri, Brunno, Lu... sempre presentes. 
Das formas lingüísticas reveladoras da experiência subjetiva, nenhuma é tão rica quanto aquelas que exprimem o tempo, nenhuma é tão difícil de explorar, a tal ponto estão arraigadas as idéias preestabelecidas, as ilusões do "bom senso", as armadilhas do psicologismo. (BENVENISTE, 2006, p.70) 


\section{RESUMO}

O tempo da linguagem é regido por coordenadas gerais. Um modelo descritivo geral do tempo localiza a noção de tempo de um enunciado coerentemente com as informações gramaticais. Partindo-se da hipótese lógica de que o passado deveria ser sempre passado, o futuro sempre futuro e o presente sempre presente, foram investigadas as localizações temporais que servem de momentos de referência ao tempo dos enunciados, sem perder de vista o momento da produção-recepção do ato de enunciar. Os níveis de compreensão do tempo na linguagem foram sistematizados em etapas: investigando o tempo do mundo, depois o tempo da linguagem e, por último, o tempo do discurso entendido como o "mundo possível" criado pela linguagem. Percebe-se que o tempo físico e psicológico interpretável de um modo geral pelo homem possui duas orientações, e que a linguagem também geraria duas formas de tempo, construídas por dois grandes sistemas temporais: o mundo comentado e o mundo narrado, inspirados em Weinrich. Eles podem descrever duas grandes intenções do interlocutor, e não apenas dois grandes grupos de formas modotemporais dos verbos. Descobrindo-se quais são os lugares temporais, e utilizando principalmente construtos inspirados em Reichenbach, foi investigado como se dá a relação entre os momentos dos eventos, os momentos da fala e o momento presente pressuposto da enunciação. Dentro de uma abordagem da semântica formal, da teoria cognitiva e da semiótica francesa, o sistema temporal da linguagem pode ser descrito mais adequadamente. A dissertação analisa vários enunciados orais e escritos.

Palavras-chaves: Tempo. Linguagem. Língua portuguesa. Reichenbach. Weinrich. Enunciação. 


\begin{abstract}
The notion of time is governed by specific coordinates in the languages. A general descriptive model deals with the expression of time by referring it to grammatical information. Based upon the logical assumption that the past should always be the past, the future always be the future and the present always be the present, it has been determined how time is located in an utterance, i.e., the reference moment and its relation to the speaking moment and the enunciation. The level of understanding of time in languages must be organized in two stages: first, by investigating the time from the physic and the linguistic point of view; and second by setting the possible world created by the discourse. Usually, the physical and psychological interpretation of time by ordinary people runs in two directions that matches with the dual linguistic time framework: one that takes into account the commented world and the other that is implemented by the spoken world, according to Weinrich. On the other hand, our time model can describe the speaker's main intentions that is not only the traditional identification of tense from the verbs. Following Reichenbach approach to the expressions of time in the languages, the parameters of event and reference moments were investigated in relation to the parameter of speaking moment, presupposed in the utterance. Moreover, the linguistic temporal system can better understood when we take into account the contributions from semiotics and from the cognitive semantics. Besides the theoretical approach to the subject, this dissertation analyzes several examples from the oral and written Portuguese language.
\end{abstract}

Keywords: Time. Language. Portuguese. Reichenbach. Weinrich. Enunciation. 


\section{SUMÁRIO}

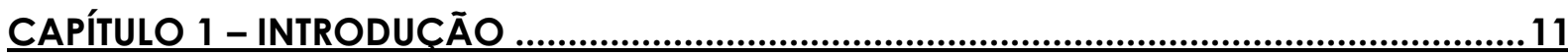

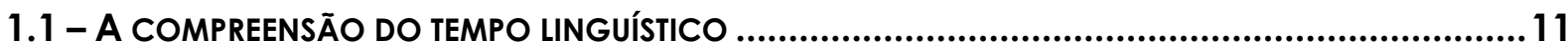

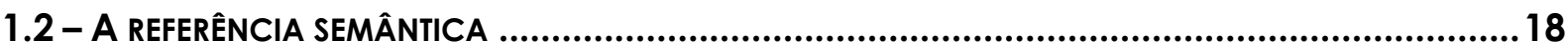

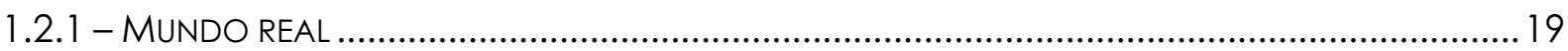

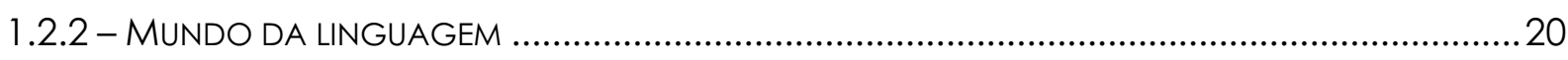

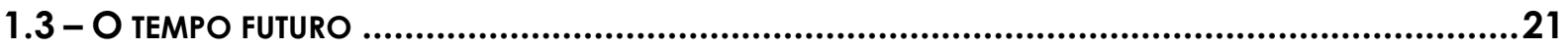

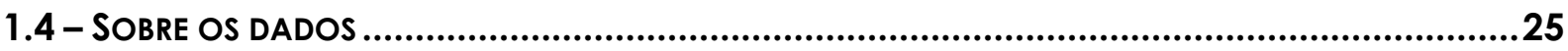

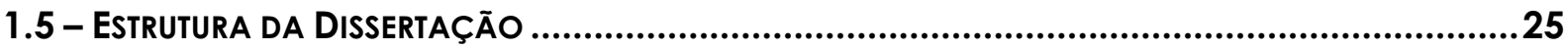

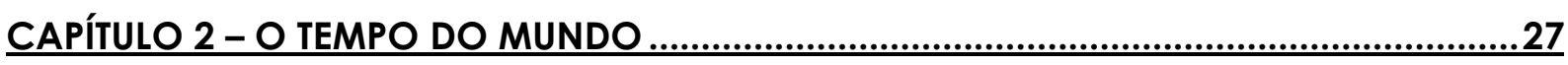

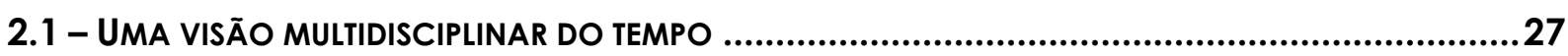

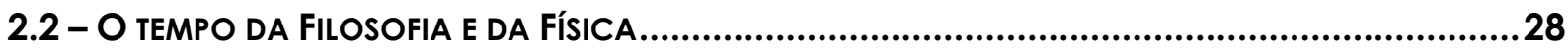

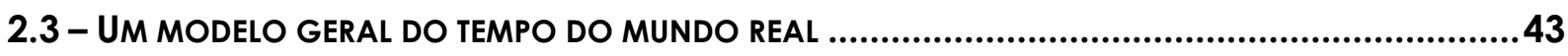

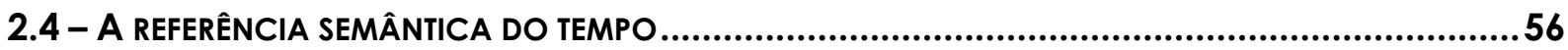

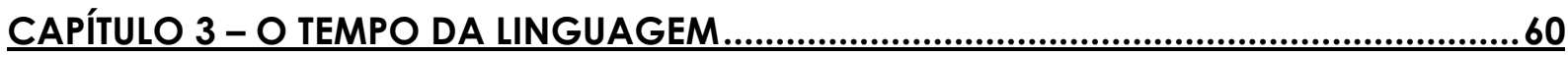

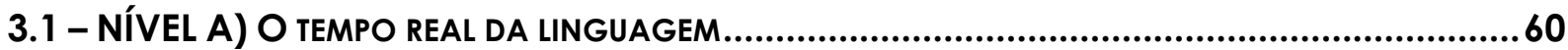

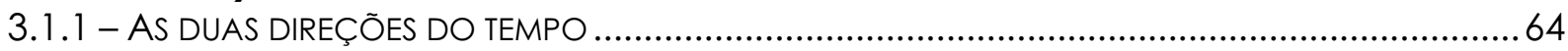

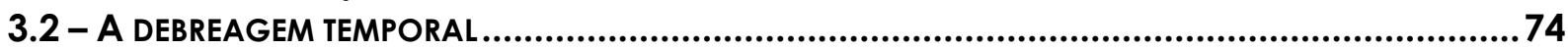

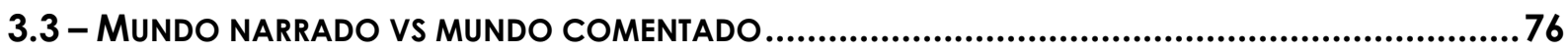

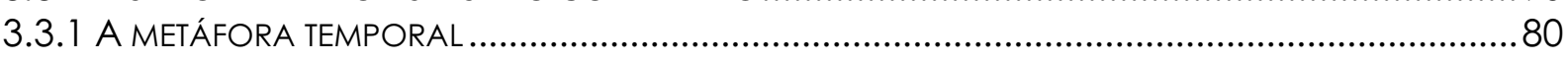

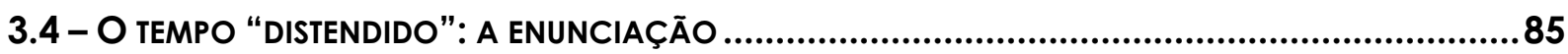

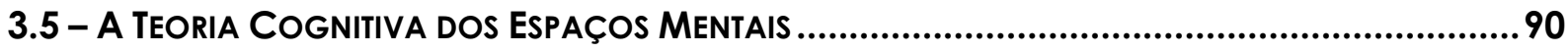

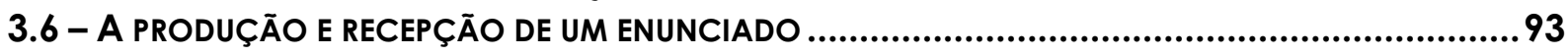

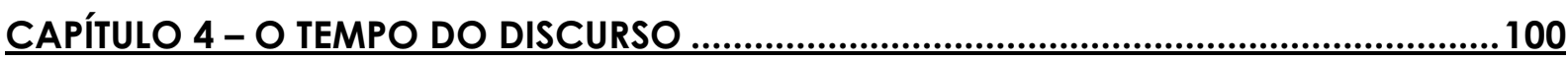

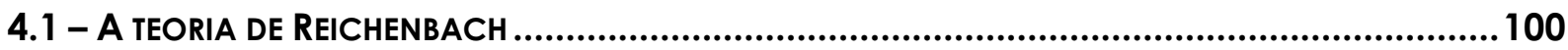

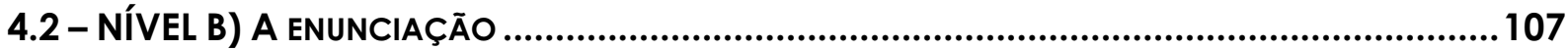

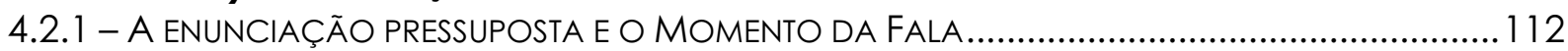

4.3 - NÍVEL C) A ENUNCIAÇÃO ENUNCIADA EM SEUS MRS ..................................................115

4.3.1 - SOBRE A NATUREZA DO CONSTRUTO DO MOMENTO DE REFERÊNCIA (MR) .........................117

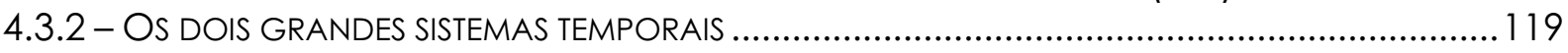

4.3.2.1 - A proposta greimasiana da temporalidade do discurso ................................. 119

4.3.2.2 - Nossa proposta de descrição dos dois sistemas temporais do discurso a

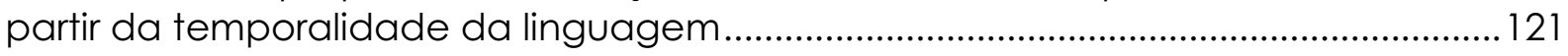

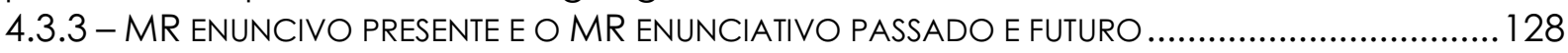

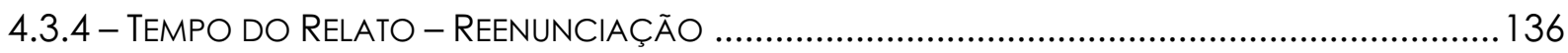

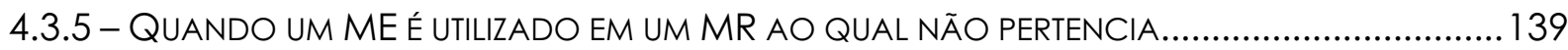

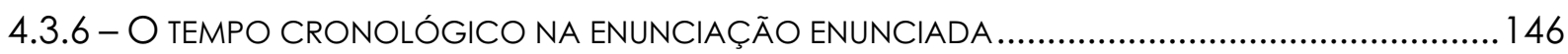

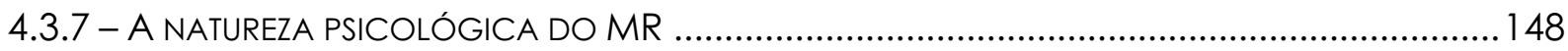

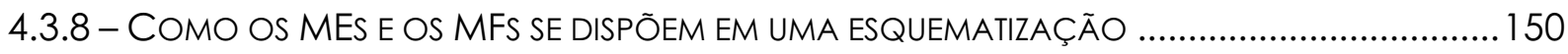

4.3.9 - OS MOMENTOS DE REFERÊNCIA E OS ESPAÇOS MENTAIS ................................................ 157 


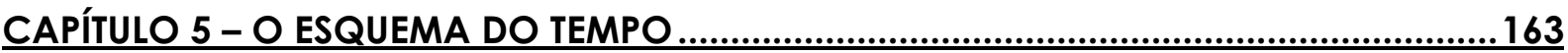

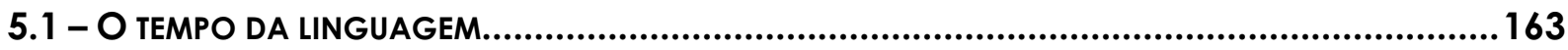

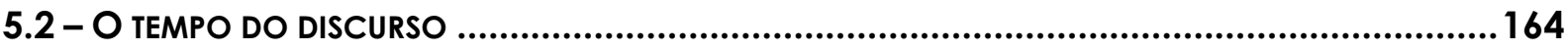

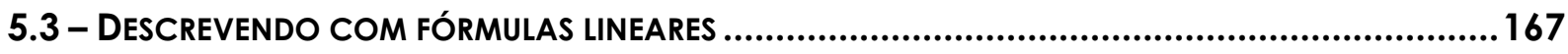

CAPÍTULO 6 - CONCLUSÃO …….......................................................................178

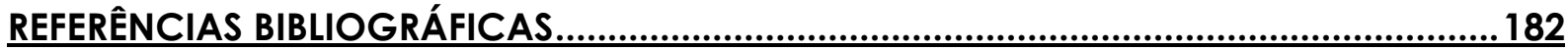




\section{Capítulo 1 - INTRODUÇÃO}

\section{1 - A compreensão do tempo linguístico}

A noção de tempo na linguagem é tratada pelos falantes como algo óbvio, a respeito do qual não precisam mais conhecimentos do que os que já têm, com uma simples observação sobre a linguagem. Em outras palavras, apesar da complexidade da noção linguística de tempo, os falantes não apresentam dificuldades para falar, nem para entender essa noção. Sua complexidade aparece somente quando o linguista começa a explorar todas as suas implicações.

Basta um único olhar linguístico em um texto que seja maior que uma oração - mesmo que seja um texto pequeno - para que ele nos revele estruturas "arquitetônicas" de tempo; isto porque as expressões de tempo vão passando do nível morfológico para o sintático, deste para o semântico, e alcançam o nível textual, onde essa arquitetura será completada. Ao refletirmos linguisticamente sobre um texto, percebemos que a nossa capacidade de localizar e imaginar na "linha do tempo" os enunciados que lemos necessita de vários níveis de compreensão. Não só pode, mas deve ser estudado observando outros níveis para, por exemplo, não incorrermos em algumas afirmações sobre a língua. Isto se torna bastante evidente quando pensamos na tradicional afirmação que diz que, no discurso ${ }^{1}$, um tempo verbal está sendo usado por outro, sem levar em conta outros elementos da oração que, na verdade, comandam o significado temporal das orações. Isto acontece porque, de modo geral, a tradição nos estudos sobre o tempo linguístico se limita a descrever o tempo verbal no que se refere apenas a sua questão de localização dos acontecimentos em relação ao momento da enunciação (enunciada).

O tempo é uma categoria bastante complexa, que não se reduz, como pensam as gramáticas, à questão da localização dos acontecimentos em relação ao momento da enunciação. Sem dúvida nenhuma, esse é um dos mais importantes elementos da temporalidade lingüística. No entanto, ele não esgota o problema. (FIORIN, 2007, p.1).

Há algum tempo, aponta-se para uma aparente contradição entre o nome de algumas formas morfológicas de verbos e o seu emprego semântico. Um enunciado pode apresentar uma flexão de tempo com, por exemplo, o nome de 'presente', mas o seu sentido pode ser de

\footnotetext{
${ }^{1}$ Consideramos o termo discurso como a atividade comunicativa de um falante, numa situação de comunicação dada, e manifestado linguisticamente por meio de textos (FÁVERO; KOCH, 2000, p.25).
} 
um tempo verbal com o nome de 'futuro do presente'. Surgem afirmações como as de que os significados dos verbos estão sofrendo uma simplificação. Outra afirmação que podemos encontrar é a que diz que o 'pretérito perfeito' e o pretérito 'mais-que-perfeito' estão sendo usados, em alguns contextos ${ }^{2}$, apenas pelo 'pretérito perfeito'.

Esta "simplificação" é vista como indo ao encontro dos princípios de simplificação e economia de esforço linguístico. Também foi vista como um alargamento das funcionalidades dos três tempos verbais, que se tornam mais abrangentes nos contextos de utilização e, consequentemente, menos específicos.

Por exemplo, sobre um enunciado do tipo:

\section{(1) Amanhã estudo Matemática.}

costuma ser dito que temos um verbo na forma de presente com valor de futuro, ou seja:

\section{(2) Amanhã estudarei Matemática.}

Mas não é apenas o verbo que traz o valor futuro em (1), e, sim, o enunciado como um todo. Afirmar que é o verbo seria o mesmo que dizer que há um morfema flexional com dois significados. Entretanto, não acreditamos que as formas temporais dos verbos estão perdendo especificidade e acumulando sentidos.

Com o avanço dos estudos lingüísticos, abrangendo fatos além das regras gramaticais e do significado lexical, a ênfase, nos estudos sobre o tempo, se deslocou para o campo do discurso e da pragmática. Além do tempo verbal, há de se considerar, agora, o significado temporal lingüístico, revelado por fatos não morfossintáticos, mas de uso da linguagem, e oriundos das situações dialógicas, interacionais, conversacionais, etc. (CAGLIARI, 1988, p.4).

Por meio de investigações pragmáticas, poderíamos fazer análises lógicas do tempo do discurso, dando os significados dos tempos verbais contextualizados. Entretanto, essas análises lógicas “[...] fazem parecer ser uma interpretação inadequada e não satisfatória para esses fatos, de um ponto de vista estritamente lingüístico.” (CAGLIARI, 1988, p.4). Isso significa que o fenômeno do uso de um tempo verbal por outro não pode ser explicado apenas esclarecendo seu contexto, ou seja, a relação pragmática entre o signo utilizado e a intenção

\footnotetext{
${ }^{2}$ Empregaremos o termo contexto sem maiores compromissos com alguma teoria específica que tome esse conceito como objeto de análise.
} 
do falante (interpretante), mas devemos, antes disso, explicar melhor o mecanismo do tempo da linguagem, porque é este mecanismo que permite esse fenômeno ser explicável contextualmente, e isso pode se dar com um estudo semântico sobre os fatos reais do tempo.

Vamos utilizar o seguinte exemplo para mostrar o que seria uma explicação basicamente pragmática:

\section{(3) Quebrou, pagou!}

Pensando-se esse enunciado como apenas um aviso de que o que for quebrado deve ser pago, e não a constatação de que algo quebrou e alguém pagou, e, por exemplo, proferido por um vendedor de cristais a um possível comprador que observa as prateleiras, quando aquele explica ao cliente a "política" da sua loja.

O exemplo (3) pode apresentar explicações do tipo: trata-se de um enunciado formado pelo tempo verbal de 'pretérito perfeito' com valor de 'futuro do subjuntivo', cujo enunciado equivalente poderia ser:

(4) Se você quebrar, você terá que pagar!

Embora esses efeitos de sentido sejam necessários, também, na interpretação de todo o enunciado e do seu contexto de produção, precisamos saber fazer outras perguntas:

\footnotetext{
Então, por que uma mesma palavra, ora está no presente, ora no passado ou no futuro, sem ser ambígua, segundo a interpretação tradicional do significado temporal dos verbos? Será que a forma passado é sempre passado? Será que a incoerência em discussão não mostra que há diferentes níveis de tempo na linguagem, e que o significado temporal de um texto só pode ser adequadamente entendido e descrito quando esses vários níveis são devidamente considerados? (CAGLIARI, 1988, p.6).
}

Nossa hipótese inicial foi de que as idéias de tempo - as noções de passado, presente e futuro - poderiam ser colocadas numa escala temporal, em sequência, em que, neste contínuo, a marca do tempo seria sempre muito coerente: passado é sempre passado, presente é sempre presente, e futuro é sempre futuro. E o falante, dependendo da sua intenção, projeta seu enunciado para os mais diversos lugares enunciativos estabelecidos por Momentos de Referência a partir dessas três categorias: passado, presente e futuro.

Acreditamos que um modelo que descreva essas relações seja passível de formalização, porque deve a língua sistematizar de forma clara todo o seu sistema do tempo. 
Defendemos a tese de que não há nada de ilógico ou desorganizado nos mecanismos de tempo linguístico.

Os tempos, no discurso, fogem das rígidas convenções do sistema, mesclam-se, superpõem-se, perseguem uns aos outros, servem de contraponto uns aos outros, afastam-se, aproximam-se, combinam-se, sucedem-se num intricado jogo de articulações e de efeitos de sentido. No entanto, como no contraponto, obedecem a regras, a coerções semânticas. O discurso cria o cosmo e abomina o caos. (FIORIN, 2008, p.229).

Devido à complexidade dos mecanismos da enunciação, principalmente no que se refere a uma de suas categorias básicas - o tempo -, uma proposta como a nossa encontra justificativa e relevância. Afinal, trazer aos olhos um modelo, no qual se possam ver descritas de forma clara as diversas projeções de tempo, poderia ser uma proposta de metodologia a mais para os estudos sobre a formalização do tempo linguístico.

Para entender, de forma ampla, a noção do tempo da língua portuguesa, procuramos investigar os limites do tempo, e sentimos necessidade de estudar esse objeto sob três pontos de vista: enquanto fenômeno da natureza (capítulo 2), enquanto fenômeno essencial para o funcionamento da linguagem humana (capítulo 3), e, só então, enquanto fenômeno criado pelo discurso (capítulo 4).

Entendida a tripartição metodológica sobre o tempo geral, porque era necessário distinguir três naturezas de tempo, mostraremos, por meio de nossas descrições ilustrativas, que os três tempos que investigamos estão interligados: o tempo do mundo ao tempo da linguagem e este, ao tempo do discurso.

Entendemos que o tempo estritamente linguístico apresenta quatro níveis de interpretação. Esses quatro níveis necessitam, para uma descrição linguística, de duas das nossas três naturezas distintas de tempo: o tempo da linguagem (capítulo 3) e o tempo do discurso (capítulo 4). O tempo que restou - o tempo do mundo (capítulo 2) - entraria na questão referencial dos falantes: de que tempo se fala e quando se fala.

A teoria mais importante utilizada nessa Dissertação sobre como o tempo natural "passa" ao tempo da língua - e que na verdade foi a grande motivadora deste trabalho - é a de Reichenbach (1966), que utiliza três construtos: ME - momento do evento, MF - momento da fala, e MR - momento de referência. A grande questão que se trabalhou sobre sua teoria foi tentar entender melhor qual é a natureza de um de seus construtos: o Momento de Referência, porque é este construto que determina os espaços mentais em que estabelecemos temporalmente nossos enunciados dentro da nossa mente. Quanto aos outros dois construtos, as relações entre as expressões linguísticas entre os eventos (MEs) e o ponto zero do momento 
da fala (MF) podem ficar fixados em um modelo simples, permitindo uma interpretação dessas expressões com um vocabulário mais simplificado e coerente, onde:

- Presente: evento simultâneo à fala (ME,MF);

- Passado: evento anterior à fala (ME - MF);

- Futuro: evento posterior à fala $(\mathrm{MF}-\mathrm{ME})^{3}$.

Reconhecemos a necessidade de estudar em que "momento", "eixo" ou "suporte" se dá essa fala (MF) e descobrimos que esse "meio temporal" no qual o MF se instá-la é um Momento de Referência. Portanto, a relação entre ME e MF ganha variabilidade discursiva dentro das possibilidades de posicionamentos de MRs, e dentro das inúmeras combinações internas a um MR, identificado como um espaço mental (mental space) da teoria cognitiva de Gilles Fauconnier (1984).

Nós estamos buscando esquematizações formais, como as de Reichenbach (1966), porque acreditamos nas fórmulas.

Ora, os aspectos do processamento verbal que lembram um cálculo são muito mais numerosos do que se costuma pensar, e a fórmula que consiste em estudar as línguas naturais apoiando a intuição pela exatidão do formalismo é a grande responsável por todos os grandes avanços por que passou até hoje nossa compreensão dos fenômenos lingüísticos. (ILARI, 2001, p.83).

A primeira dificuldade em um estudo sobre o tempo linguístico é saber explicar de que tempo se fala. $\mathrm{O}$ “[...] termo tempo recobre representações muito diferentes, que são as muitas maneiras de colocar o encadeamento das coisas [...]" (BENVENISTE, 2006, p.70), e, por isso, metodologicamente, distinguimos, como já dissemos, quatro níveis de interpretação do tempo linguístico. Os quatro níveis necessários a uma descrição do tempo linguístico são:

A) o momento da produção(-recepção), em que o falante calcula o seu aqui-agora real para poder "enunciar", uma vez que o tempo linguístico necessita, como ponto de partida, de informações temporais extralinguísticas. Trata-se do tempo real levado em consideração no momento do ato discursivo (recepção ou produção);

B) o tempo presente pressuposto da instância da enunciação enunciada; esse nível assimila o tempo real de um enunciado transformando-o em um presente pressuposto, que será concomitante a MF, ou seja, ao ponto zero lógico de um momento de referência (MR);

C) os MRs, ou seja, a temporalidade da enunciação enunciada (discurso), pois, considerando-se o texto como uma sucessão de períodos que formam blocos de significações

\footnotetext{
${ }^{3}$ Segundo Comrie (1885 apud CORÔA, 1998, p.48), essas são as caracterizações básicas da definição temporal nas línguas ocidentais.
} 
- colocados uns ao lado de outros pelo raciocínio, coesão, argumentação, lógica dos fatos e das ideias que se quer transmitir -, o momento da fala movimenta-se ao longo da atualização de um discurso, se reposicionando como um ponto presente, para que as noções do tempo sejam encadeadas; trata-se do tempo do discurso (enunciação enunciada). Nele se investiga as opções de escolha do tipo de eixo temporal, determinado por Momentos de Referência, correspondentes, na nossa proposta, ao construto do MR reichenbachiano. Devemos nos lembrar que o uso de um determinado MR depende da perspectiva do enunciador e não do contexto discursivo. Em outras palavras, esse terceiro nível (C) trata de um tempo que é um suporte mentalmente construído, como um plano inercial de tempo (MR), em que somos levados, pela vontade do enunciador, a nos situar enunciativamente, por uma relação de tensão ou relaxamento com o que é enunciado;

D) a temporalidade proveniente das relações temporais particulares em cada subsistema temporal, determinadas principalmente pelos verbos; estabelecida a perspectiva temporal (MR); o quarto nível trata de como se articulam os tempos dos eventos (ME) em relação ao Momento da Fala.

Todos esses níveis são levados em conta na compreensão da temporalidade de um discurso, ou texto, e eles se articulam de tal forma que um depende intrinsecamente do outro.

Ainda há pouca sistematização nos estudos das línguas sobre aquilo que estamos chamando de subsistemas temporais determinados por MRs. Estudos sobre esses eixos poderiam ajudar as gramáticas a mostrarem, por exemplo, que algumas formas verbotemporais no português não estão perdendo especificidade.

Tentamos sistematizar a imbricação dos níveis de compreensão do tempo. Procuramos desenvolver um modelo formal descritivo dos modos de expressão linguística do tempo para provar, com o que reflete desse modelo, que o tempo da língua possui regularidades, e estas podem explicar qualquer formação temporal linguística.

A ideia de que um estudo do tempo requer uma teoria enunciativa foi pouco discutida até o século XX. Felizmente, nas últimas décadas, se tem dado atenção a essa questão porque se percebe que sem ela não é possível explicar os "efeitos de sentido" criados nos enunciados. Entretanto, percebemos a necessidade de um estudo do tempo visto pela enunciação juntamente com a noção de Weinrich (1968) e de outros estudiosos da linguagem que subdividem o sistema temporal da língua em dois: mundo ${ }^{4}$ narrado e mundo comentado. Percebemos que sem uma distinção fundamental como essa não seria possível um estudo

\footnotetext{
${ }^{4}$ Entende-se por mundo o possível conteúdo de uma comunicação linguística.
} 
adequado do Momento de Referência (MR), que é, para nós, o principal responsável pela construção da noção de tempo na linguagem. Este construto prova que o tempo não é apenas um efeito de sentido construído durante a enunciação, mas que a linguagem possui formas que demonstram sua dependência referencial com o tempo cronológico e sua dependência com a intencionalidade do enunciador.

A dificuldade de se esquematizar o tempo da língua reside principalmente no nível do Momento da Referência (MR), pois exige um domínio sobre muitos mecanismos enunciativos e muitas orientações de ordem cultural e cronológica que, com certeza, estão atuando para o sentido temporal final de um texto, pois há uma diversidade enunciativa da linguagem que cria várias formas de "temporalizar" situações. Isto se tornou mais claro com exemplos do tipo (3) Quebrou, pagou, em que percebemos que há questões de ordem dêitico-pragmática e referencial anterior a de ordem do discurso; não seria possível analisar o tempo em (3) sem primeiramente descrever a noção temporal estabelecida contextualmente.

Gostaríamos de propor um modelo descritivo básico da temporalidade da língua portuguesa para que qualquer produção verbal pudesse ser analisada quanto a sua temporalidade, indexando o "lugar" temporal dos enunciados no modelo. Esse pequeno estudo é a tentativa de mapeamento das operações temporais processadas cognitivamente no ato da comunicação. Investigamos principalmente as formas verbais simples do modo indicativo. É importante não esquecermos que,

[...] embora as informações sobre o tempo constituam um sistema, que pode ser objeto de uma análise específica, esse sistema mantém relações complexas, mas ainda pouco conhecidas com outros sistemas, como a modalidade, o aspecto verbal e os mecanismos de coerência e coesão textual. Há muito a aprender numa separação cuidadosa dessas informações, que a tradição gramatical vem confundindo há séculos; (ILARI, 2001, p.82).

Nosso modelo do tempo deveria partir de uma noção de tempo entendida de alguma forma. Infelizmente, não se sabe com clareza o que é o tempo e como funcionam todas as formas que ele assume, como anterioridade, concomitância, passado, futuro, antecipação, movimento, estado, repetição, aspecto, etc. Por esse motivo, percebemos que era imprescindível estudar primeiramente a interpretação física, filosófica e psicológica do fenômeno tempo, para, após isso, podermos tentar descrever uma sistematização do tempo enquanto forma linguística. Buscamos em estudos de outra natureza considerações para tentar explicar como a linguagem humana revela as questões temporais na sua estrutura e uso.

A partir de Saussure, passamos cada vez mais a enxergar a língua como um fenômeno muito complexo. A intercomunicação entre todas as ciências que se faz nos dias de hoje deve 
ser observada por quem estuda o tempo na linguagem, porque talvez a dificuldade que os estudiosos do tempo encontram para explicar os mecanismos temporais da língua pode estar relacionada com a falta inicial de metalinguagem adequada e de modelos descritivos mais ousados, numa época em que apenas estudos puramente gramaticais deveriam diagnosticar a estrutura de uma língua.

\section{2 - A referência semântica}

Este estudo restringe-se ao modo indicativo - embora possa usar alguns exemplos com verbos em outros modos - porque reconhecemos que é nesse modo verbal que a categoria temporal aparece menos imbricada de noções modais, e aparece mais definível numa linha do tempo, onde podem ser localizadas as noções de passado, presente e futuro. Esses três "pedaços" da linha do tempo são lugares conceptuais de tempo.

Embora saibamos que a noção de aspecto é muito importante e interessante dentro dos estudos sobre o tempo, não trabalhamos com ela. Nosso trabalho se restringe ao que Lacey (1972) chama de questão fundamental subjacente à linguagem temporal: a questão "Quando algo aconteceu?" (LACEY, 1972, p.14), ou seja, onde se localiza um evento na linha do tempo.

Para os gramáticos tradicionais, o modo indicativo exprime fatos de um mundo real, certo e positivo, ou seja, o falante, ao empregar o modo indicativo, demonstra sua atitude de querer apresentar o fato como pertencente a um mundo real, certo e positivo.

A diferença modal entre um enunciado como (4) Se você quebrar, você terá que pagar! e um equivalente quanto ao seu contexto como (3) Quebrou, pagou! está, entre outras coisas, na atitude que o enunciador atribui à apresentação de um mundo real, fictivo, construído em (3), e à apresentação de um mundo hipotético, em (4). A escolha por tempos no indicativo em (3) se revela na intenção do falante em apresentar um enunciado "certo de acontecer"; além disso, a referência que se tem do tempo, neste exemplo (3), é de um tempo anterior - o passado -, tornando os acontecimentos mais certos ainda, por já terem ocorrido.

Basicamente, o tempo gramatical define um futuro, um passado e um presente. Os enunciados, com seus verbos no indicativo, mais advérbios, termos temporais, e outras expressões de tempo, representam, na sua compreensão temporal total, uma referência a uma 
dessas três "parcelas" de tempo, pertencentes a um mundo possível - e, nesse sentido, real criado pela linguagem.

\subsection{1 - Mundo real}

Os estudos sobre o tempo precisam saber definir o que representa referencialmente um futuro, um passado e um presente. Entendidos individualmente, passado, presente e futuro são lugares temporais definidos a partir de um momento agora de cada falante. O futuro é o que virá a partir do seu agora, o passado é o que já passou deste agora, e o presente é o momento do agora. Cada uma dessas três noções se apresenta em nossa mente na forma de um pequeno filme interiorizado, pelo qual visualizamos ações, lugares e movimento no tempo. As cenas do filme podem ser de ações passadas, futuras ou atuais. Trata-se das formas do tempo interpessoais e não cronológicas.

Se a faculdade cerebral da memória funciona bem e é bem desenvolvida, poderíamos dizer que o passado é um lugar mental altamente produtivo, complexo e extenso. Como a concepção de um passado depende de memória, o passado é uma noção individual, porque a memória é uma faculdade humana ativada individualmente. O mesmo acontece com o presente e o futuro, que dependem da mesma memória para a construção do pensamento atual (presente) e a imaginação (futuro). Podemos pensar em um passado graças à memória e à imaginação, e podemos pensar em um futuro graças à imaginação, à memória, e a uma capacidade cultural de projeção do futuro. Por meio da abstração, criamos uma extensão maior que o instante do agora (que, na realidade, não tem extensão) para que se possa chamar o instante presente de momento presente.

O passado e o futuro são abstrações: construções mentais que povoam a memória e a expectativa humanas. [...] Embora menos abstrata e mais colocada à experiência comum, a noção de presente traz também sua dose de abstração. Do que é feito o aqui-e-agora em tempo real? Qual a textura dessa divisa deslizante entre passado e futuro a que chamamos "presente"? (GIANNETTI, 2005, p.139).

Essa metáfora do filme interiorizado representa a mentalização individual do tempo real, quando se toma como instante agora o próprio instante individual. Entretanto, quando enunciamos, mobilizamos a linguagem, criando um discurso que possui seu próprio instante 
do agora. Neste sentido, o presente, o passado e o futuro são de outra natureza: a natureza enunciativa. Embora represente um agora, o centro de orientação do discurso sempre será anterior ao momento real. Esse discurso, entendido como texto, resultante da comunicação oral ou escrita, produz o seu próprio filme, pois a ordem do diretor deste filme, no set de gravação, “- Luzes, câmera, ação!”, inicia um outro tempo, o tempo do discurso - ou texto -, em que nos esquecemos da realidade empírica e passamos a tomar conhecimento de uma outra realidade: a realidade do filme. Essa independência entre o tempo do texto e o tempo do mundo é apenas aparente. Em um filme, tomamos conhecimento de um espaço (luzes), de eventos (ação), mas também de um olhar (câmera), com a qual o diretor possa orientar seu ponto de vista ao espectador. E, com mais essa metáfora, comparamos o discurso, que possui intenções que revelam um falante real. Em outras palavras, o mundo possível - o universo próprio da linguagem - não representa mais um filme interiorizado, mas um filme "assistido", ou seja, este filme é sempre anterior a nossa visualização, e possui uma câmera que manipula o tempo e o espaço.

\subsection{2 - Mundo da linguagem}

Quando esse "filme" interiorizado emerge no seio da instância do discurso, tornandose conhecido pelo discurso a uma outra pessoa (que pode ser ela mesma), passamos ao domínio do mundo da linguagem, que tem o tempo linguístico em potência e o atualiza. Esse fazer o outro conhecer o nosso discurso pode ser chamado de ato de fala. $O$ ato de fala continua sendo individual.

Em conseqüência disso, a temporalidade lingüística deveria se realizar no universo intrapessoal do locutor como uma experiência irremediavelmente subjetiva e impossível de ser transmitida. [...] Mas este argumento é falso. Algo singular, muito simples e infinitamente importante se produz realizando algo que parecia logicamente impossível: a temporalidade que é minha quando ela organiza meu discurso, é aceita sem dificuldade como sua por meu interlocutor. (BENVENISTE, 2006, p.77).

Possuímos três lugares referenciais mentais, a partir de um ponto zero: presente, passado e futuro. No discurso, o ponto zero é dado pela situação do discurso. No mundo real, ele se dá com o presente individual de cada pessoa. 
Veremos que, à semelhança das cenas de um filme que conta acontecimentos passados e/ou futuros e/ou presentes, cada lugar temporal é composto por cenas. Essas cenas são como os espaços mentais da teoria cognitiva de Gilles Fauconnier. Os espaços mentais do discurso se localizam em um lugar temporal do mundo possível e em um lugar temporal do mundo real para o falante. Por exemplo: um enunciado de um bilhete, em que se diz amanhã, abre um espaço mental dentro de um lugar temporal futuro no mundo possível, mas, se o falante lê o discurso no dia posterior ao que o enunciador escreveu, o amanhã pode se inscrever em um lugar temporal presente no mundo real. Isso porque "O tempo do discurso nem se reduz às divisões do tempo crônico nem se fecha em uma subjetividade solipsista." (BENVENISTE, 2006, p.78).

Enquanto o mundo real apresenta basicamente três lugares conceptuais de tempo, o mundo possível, grosso modo, também apresenta três lugares temporais como podemos observar por meio dos morfemas verbais de tempo. Porém, eles podem ser matizados por diferentes atitudes comunicativas. O discurso, basicamente escrito com tempos do indicativo, irá se comportar com duas atitudes comunicativas, segundo Weinrich: criará um mundo narrado ou um mundo comentado.

\section{3 - O tempo futuro}

Sabemos que muitos linguístas, como Lyons, atribuem ao tempo gramatical futuro um caráter modal mais do que temporal. Um dos motivos é por se considerar que o tempo futuro não existente realmente: é sempre suposto ou imaginado. Antigamente, entender o futuro como não possível de conceber valor de verdade poderia encontrar respaldo nas reflexões filosóficas clássicas sobre o tempo. Mas, será que hoje, com as revoluções tecnológicas do mundo moderno, podemos dizer que ele não exista? Iremos considerar o tempo futuro como um "lugar" na linha do tempo, da mesma forma que consideramos o passado e o presente, porque estamos pensando na intuição dos falantes, que entendem o futuro como um ponto de referência posterior. Isto se torna mais evidente se procuramos entender como o conceito de futuro se desenvolveu ao longo das civilizações. Podemos dizer que, hoje, nossa percepção do futuro é mais extensa do que antigamente. Como podemos ilustrar na seguinte figura 1, nossa 
linha do tempo mental estendeu a porção da linha do tempo futuro, pois estaríamos fazendo previsões de futuro mais sofisticadas.

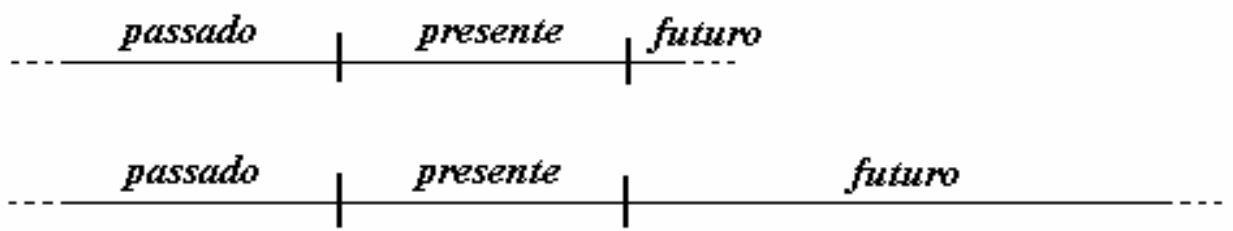

Figura 1 - O alargamento da parcela de tempo futuro na linha do tempo

Para entender a evolução da concepção do tempo futuro, podemos tomar, como exemplo, uma outra noção: o espaço. As sociedades antigas, não acostumadas com a tecnologia da internet, da televisão, dos meios de locomoção, como o avião, etc, possuíam uma geografia internalizada muito limitada. Acredita-se que, a partir do advento do trem, a geografia mental foi se modificando, aumentando seu espaço mental imaginativo do espaço. Isto porque nós passamos a percorrer grandes distâncias muito rapidamente com o trem. Podemos pensar em mais uma fase de "alargamento" da noção de espaço, quando o homem passou a observar grandes extensões de terra pela janela de um avião, localizar qualquer ponto do planeta com o "google map" da internet, etc. Podemos até, por exemplo, afirmar que um astronauta possui uma geografia mental maior que a de outras pessoas, porque dentro da sua mente há uma memória de ter visualizado um espaço muito amplo, como o Universo.

Como o corpo (os olhos) passou a entender um espaço maior, e a perceber que o seu deslocamento no espaço também estava maior, a mente internalizou uma competência geográfica maior, estando essa mudança de acordo com a teoria moderna de que a mente e o corpo são dependentes um do outro.

A concepção temporal também sofreu um alargamento ao longo dos anos. Segundo BERNSTEIN (1997), o advento da faculdade de fazer o cálculo da probabilidade libertou a humanidade dos oráculos, dos adivinhos e do destino imposto pelos deuses, que faziam com que o homem pensasse que não poderia prever e mudar seu futuro. Nós aprendemos a como pôr o futuro a serviço do presente. As probabilidades nos trouxeram cálculos e números mostrando quais são os eventos esperáveis no futuro, mas o homem pode levar o resultado dessa "estimativa" em conta ou não. Dependerá de sua vontade. "Ao mostrar ao mundo como compreender o risco, medi-lo e avaliar suas conseqüências, eles [um grupo de pensadores] converteram o ato de correr riscos em um dos principais catalisadores que impelem a sociedade ocidental moderna." (BERNSTEIN, 1997, p.1). 
Podemos pensar que, se o futuro se tornou um lugar onde o homem passou a calcular e a refletir mais, também o passado pode ter se tornado um lugar mais complexo, porque um dos elementos que a probabilidade utiliza para o cálculo são as experiências passadas e é com base no passado que prevemos o futuro.

O futuro se "alargou" na mente do homem ao longo da história. O ser humano passou a se conscientizar que há opções de atuação no mundo, e que ele não é limitado pelo destino imposto culturalmente. Essas opções de escolha, entendidas como riscos ${ }^{5}$ por Bernstein, surgiram a partir do Renascimento. "Até a época do Renascimento, as pessoas percebiam o futuro como pouco mais do que uma questão de sorte ou o resultado de variações aleatórias, e a maioria das decisões era motivada pelo instinto.” (BERNSTEIN, 1997, p.18).

Segundo Shmuel Sambursky (1977, p.1-14 apud BERNSTEIN, 1997, p.16-17), quando os gregos antigos desejavam saber sobre o que aconteceria em um determinado dia, preferiam consultar os oráculos a consultar os filósofos mais sábios, sobre o que seria provável (eikos) de acontecer. Essa preferência também se deu em outros povos, como os romanos, os primeiros cristãos, os muçulmanos fatalistas, as sociedades arcaicas pré-agricolas, etc. Os primeiros padres jesuítas também relataram que tiveram dificuldade de explicar o que significava a palavra amanhã aos índios, e de fazê-los entender a disciplina da espera na atividade agrícola, e as vantagens da espera entre a produção e o consumo.

Sabemos que após 1300, o misticismo dá lugar à ciência e à lógica. Nessa fase da história,

[...] se os homens e as mulheres não estavam à mercê de divindades impessoais e do acaso aleatório, não poderiam continuar passivos diante do futuro desconhecido. Não tinham outra escolha senão começar a tomar decisões sobre uma faixa bem mais ampla de circunstâncias e sobre períodos de tempo bem mais extensos do que em qualquer época anterior. (BERNSTEIN, 1997, p.20).

A probabilidade que surgiu com o Renascimento e com o Iluminismo era pensada em termos da natureza das coisas, mas hoje sabemos que a natureza das coisas não pode ser conhecida em sua totalidade, devido a sua complexidade. "[...] os seres humanos não possuem conhecimento completo sobre as leis que definem a ordem do mundo objetivamente existente." (BERNSTEIN, 1997, p.332). Além disso, o comportamento e as decisões humanas não eram considerados. No século XX, percebeu-se que a teoria das probabilidades, tradicional por seu caráter objetivo, não refletia as nossas escolhas. Passou-se a pensar uma probabilidade mais subjetiva, em que a percepção da probabilidade, do peso e do risco

\footnotetext{
${ }^{5} \mathrm{O}$ risco é entendido como uma opção e, por isso, não mais um destino.
} 
envolvido, a crença individual, a experiência e nossas decisões, eram elementos que contribuíam para a determinação da probabilidade, e uma administração do risco passou a ser subjetiva e individual.

Um dos principais fatores que afetou a percepção do homem moderno quanto ao futuro foi o aumento expressivo da esperança de vida ao nascer ${ }^{6}$ (GIANNETTI, 2005, p.124). Com a tecnologia, a medicina e os estudos de genética de hoje, vivemos muito mais e melhor.

O animal humano que a natureza produziu não se resignou à sua condição
natural. Ele se distanciou gradualmente de suas pulsões instintivas e passou a
submetê-las, de forma mais ou menos deliberada e sistemática, ao filtro de
suas escolhas e visões do amanhã. O pano de fundo dessa mudança radical
foi a ampliação da percepção do tempo - um extraordinário alargamento da
faculdade de imaginar o futuro e reter na memória a experiência passada
visando conhecer e modificar o amanhã. A progressiva conquista da
dimensão temporal levou a uma crescente abstração do momento vivido: ao
refreamento da tirania do aqui-e-agora e ao lugar de honra que passado e
futuro vieram a ocupar em nossa vida mental. Memória e expectativa -
realidades virtuais - passaram a modular o apelo das certezas sensíveis e
desejos circunstanciais. (GIANNETTI, 2005, p.82-83).

Essa é a visão de futuro dilatada que passamos a ter ao longo dos anos. Entretanto, também há uma dilatação do futuro que ocorre ao longo do crescimento individual de cada homem moderno. A expectativa do futuro nas pessoas não se forma do nada, é um conceito adquirido graças ao ambiente cultural e às circunstâncias objetivas em que vive o ser humano, logo, uma criança e um jovem não têm ainda a construção desse espaço complexo chamado futuro. Eles apresentam apenas um lugar mental onde projetam mais imaginação do que programação.

O futuro dilatado não é só a capacidade de preencher a linha do tempo com imaginações e sonhos, mas um exercício de previsão. É esse o futuro que estamos defendendo como uma parcela da "linha do tempo".

\footnotetext{
6 "Quem nasce atualmente vive em média catorze anos (5113 dias) a mais do que alguém nascido nos anos 60 e aproximadamente o dobro do que era comum até o início da revolução industrial do século XVIII." (GIANNETTI, 2005, p.125).
} 


\section{4 - Sobre os dados}

Os dados analisados são exemplos da linguagem verbal oral e escrita do português do Brasil, extraídos de jornais, revistas, gramáticas, romances literários, diálogos reais, e exemplos construídos por nós. Esses exemplos de enunciados e suas relações temporais são a motivação desta Dissertação. Ao mesmo tempo em que se analisaram algumas teorias sobre o tempo, se percebeu como os estudos linguísticos sobre esta noção podem ser tão fascinantes, mas ainda oferecer poucas soluções para os problemas que toda e qualquer categoria da língua pode apresentar.

Não nos preocupamos em analisar apenas enunciados que empregavam termos temporais corretos gramaticalmente, porque quisemos fazer uma descrição real de fatos reais, da fala real de falantes reais, seja em modalidade escrita ou oral. Afinal, a própria tradição gramatical descreve alguns usos de um tempo por outro, resultando em uma série de justificativas, como presente histórico, vícios e figuras de linguagem, etc.

Tradicionalmente, se concebe uma primeira diferença da ordem de produção/recepção entre o tempo de um texto escrito e o tempo de um texto falado. Diz-se, por exemplo, que quando na modalidade escrita se emprega um termo dêitico do tipo hoje, pode-se não se saber localizar com precisão esse hoje. "O único meio de empregá-lo e de torná-lo inteligível fora do presente lingüístico é o de fazê-lo acompanhar de uma correspondência explícita com uma divisão do tempo crônico" (BENVENISTE, 2006, p.78). Entretanto, da mesma forma com que uma pessoa pode escrever hoje em um bilhete para se referir ao seu amanhã - se ela quiser que alguém leia seu bilhete no dia seguinte (amanhã) e o entenda como um hoje - uma pessoa pode dizer hoje para uma data que não é o hoje da situação de comunicação face a face - por exemplo, ao ensaiar um discurso que fará num outro dia. Por esse motivo, a inteligibilidade de formas dêiticas do tempo necessita sempre de informações contextuais, não importa a modalidade da expressão verbal - se oral ou escrita.

\section{5 - Estrutura da Dissertação}


Como dissemos, o nosso objeto foi investigado por meio de três pontos de vista:

- o tempo do mundo;

- o tempo da linguagem;

- o tempo do discurso.

Cada natureza do tempo compõe um capítulo. A respeito do tempo do mundo (capítulo 2), são apresentadas, de forma resumida, muitas teorias sobre o tempo. Discutimos sobre o que os estudos de filosofia, física e psicologia já disseram e o que estão dizendo sobre o tempo. Essas disciplinas se preocuparam muito com esse objeto e elas podem nos ajudar a entendê-lo. Ao concluirmos essa revisão de literatura multidisciplinar, faremos uma tentativa de demonstração do que seria uma descrição visual do tempo enquanto fenômeno da natureza, para que possamos construir, a partir dela, uma sistematização do tempo enquanto fenômeno da linguagem.

No capítulo 3, sobre o tempo da linguagem, tenta-se entender a natureza do tempo linguístico: o tempo como algo que requer tempo e os problemas que uma análise do tempo linguístico encontra, se não se leva em conta o momento da produção e da recepção de um dado texto. Para transformar a experiência subjetiva do tempo em objeto linguístico, é preciso investigar o modo como ele se dá através da linguagem: o ato da enunciação. Como este fenômeno pertence tanto à noção de tempo da linguagem quanto à noção de tempo do discurso, encontraremos, nesse capítulo 3, o primeiro dos quatro níveis da temporalidade linguística: a enunciação.

Com relação ao tempo do discurso (capítulo 4) discutem-se os outros três grandes níveis de compreensão temporal linguística: o Momento da Fala, o Momento de Referência e o conteúdo temporal.

No quinto capítulo, verificamos como se dá uma análise do tempo no discurso por meio de um esquema que considera uma linha do tempo de orientação cronológica e uma linha do tempo enunciativa. Depois, tentaremos formalizar por meio de três construtos MF, MR e ME.

No sexto capítulo, concluiremos nosso estudo. 


\title{
Capítulo 2 - O TEMPO DO MUNDO
}

\section{1 - Uma visão multidisciplinar do tempo}

\begin{abstract}
...Penso que, diante do crescimento sempre maior e mais rápido do campo da Ciência, o confronto de disciplinas torna-se mais do que necessário. ${ }^{7}$

Jacques Monod

(ECO, 1986, p.1)
\end{abstract}

A Ciência deve ser simétrica e por isso a revisão de Literatura não se limitou aos estudos linguísticos. Como os campos de estudo se intercomunicam sempre de alguma forma, e como não temos a cultura de fazer Ciência em conjunto com estudiosos de diversas áreas do conhecimento, não podemos temer um olhar sobre as outras Disciplinas, além daquela que nos especializamos. O primeiro capítulo desta Dissertação propõe uma revisão da literatura a respeito do tempo, mas não só a literatura dos estudos das Letras, como seria normal de se esperar, mas de outros campos de estudo que têm o tempo como objeto de interesse.

O tempo é feito de espaço? Velocidade? Eternidade? Forças inerciais? Duração? Indução? É feito de um meio sensorial de Deus? É uma moldura vazia? É de natureza matemática, feito de números? Com que forma geométrica se parece o tempo para podermos adotá-la em um estudo descritivo? Um tempo cíclico, linear, contínuo? Ilimitado, nãoisotrópico, homogêneo? Rede expansória, rede comprimida, quadridimensional, espiral?

Precisamos saber até que ponto vai a complexidade daquilo que se chama tempo, quais as suas possibilidades de ser, qual o seu potencial e o seu limite, qual a sua forma, etc. Devese entendê-lo pelo olhar de outros usuários do tempo como objeto de estudo, e não só dos linguístas, porque podemos encontrar um caminho de ideias de como construir um suporte teórico que possa depois sustentar descritivamente os mecanismos do tempo da linguagem. Por isso, partimos de uma revisão geral sobre a noção de tempo, principalmente pela Filosofia e pela Física, para só depois revisar os estudos linguísticos sobre o tema.

Discutir conceitos de anterioridade, concomitância, posterioridade, memória, movimento ascendente no tempo, movimento descendente no tempo, direção retrospectiva, direção prospectiva, sucessividade, duração, dentre outros, é uma questão terminológica anterior aos estudos da linguagem. Uma vez que estamos propondo um modelo descritivo, e

\footnotetext{
${ }^{7}$ No original: ...Je pense que, devant l'accroissement, toujours plus large et plus rapide du camp de la science, la confrontation des disciplines devient plus que jamais nécessaire.
} 
modelos descritivos normalmente necessitam de recursos gráficos e vetoriais para maior visibilidade, nada mais natural do que investigar, primeiramente, de onde vieram as convenções, por exemplo, de se considerar que o futuro está à nossa frente e o passado às nossas costas.

O espaço, entendido como uma entidade do mundo real, também é uma noção bastante discutida pelas Ciências. Entretanto, é menos complicado fazer uma correspondência entre a noção espacial e a realidade física. Podemos entender o espaço, por exemplo, através da visão (ex: ao observarmos uma quadra de futebol) e através do tato (ex: dentro de um elevador, podemos sentir as dimensões espaciais do lugar em que estamos tateando ao nosso redor). $\mathrm{O}$ tempo, entretanto, é uma noção de nossas experiências e atividades que não conseguimos entender fazendo uma simples correspondência com a realidade; percebemos apenas as "consequências" do tempo.

Por outro lado, quando passamos do domínio do mundo real para o domínio dos mundos possíveis criados pela linguagem, percebemos que o espaço também é uma noção muito complexa. $\mathrm{O}$ espaço, dentro de uma teoria narrativa do discurso literário, pode ser entendido tanto num sentido físico quanto num sentido translatado (espaço social, espaço psicológico); ele deve ser selecionado pelo autor porque a linguagem não consegue esgotar a descrição de um dado objeto (seletividade fotográfica), transmitir informações de um espaço requer tempo, ou seja, ocorre somente ao longo de uma linha do tempo, etc. (REIS; LOPES, 1988, p.135-137). Outro motivo pelo qual o espaço, numa perspectiva narrativa, também é considerado complexo é que ele leva em conta "[...] o ponto de vista e a inerente estrutura perspectivada do mundo reconstruído [...]" (REIS; LOPES, 1988, p.137), ou seja, a perspectiva narrativa interfere na representação do espaço. Como veremos, o tempo, assim como o espaço, é um elemento do mundo real que, quando tratado pela linguagem, em um mundo possível (o discurso, falado ou escrito) pode sofrer uma interferência decisiva em sua descrição, dependendo da perspectiva do enunciador.

\section{2 - O tempo da Filosofia e da Física}

Desde a Antiguidade, o tempo foi objeto de reflexão pelos filósofos gregos. No século VI a.C., os filósofos se dividiam entre os que achavam que o tempo era real - como Heráclito 
de Éfeso (540 a.C. - 470 a.C.) - e os que achavam que o tempo era irreal - como Zenão de Eléia (495 a.C. - 430 a.C.) -, considerando-o uma ilusão criada pelos nossos sentidos. Tanto uma quanto outra visão, sempre pensaram o tempo juntamente com outros dois fenômenos: o movimento e o espaço; filosofar sobre o tempo necessitava também refletir sobre o movimento e o espaço, porque não se conseguia pensar o tempo sem que viessem imediatamente ao pensamento dos filósofos esses dois fenômenos. Isso fez com que se pensasse o tempo como movimento.

No século IV, Platão (428-347 a.C) discordou que o tempo fosse movimento. Para ele o tempo enquanto essência não é movimento. Platão possui a famosa teoria dos dois mundos: o Mundo das Ideias e o Mundo das Aparências. Dizia que tudo na Terra seriam cópias imperfeitas de um outro mundo, o Mundo das Ideias, onde se encontrava a essência de todas as coisas. O tempo, para Platão, pertence ao Mundo das Ideias, e se identifica com a eternidade, lugar onde não há movimento. É no mundo sensível - o mundo das aparências em que temos esse tempo confundível com o movimento, uma espécie de imagem móvel do tempo enquanto essência.

Aristóteles (384 - 322 a.C), em Física, IV, (1998), quis fazer um estudo científico do tempo, e por isso, ao estudá-lo, precisava que este não fosse confundido com eternidade, pois a eternidade não tem mudança e, consequentemente, não tem tempo, e era o tempo o que ele queria estudar. Sendo assim, o tempo para Aristóteles tinha que ser movimento ou algo relacionado com o movimento, ou derivado do movimento, pois se não há movimento então não há tempo. Em uma pequena cena de um vaso que cai da mesa, por exemplo, há um movimento - o cair do vaso, e, portanto, há um antes - o vaso em cima da mesa - e um depois - o vaso quebrado no chão; se houve o movimento e, consequentemente, um antes e um depois, então houve o envolvimento de tempo. Mesmo utilizando um exemplo em que algo aparentemente não se mexe como mexeu o vaso, o tempo pode existir. Aristóteles usa como exemplo uma pessoa no escuro que só perceberá que o tempo passa na medida em que houver um movimento em sua mente. O filósofo também explica que os conceitos de tempo e movimento encontram-se tão estreitamente relacionados que um se define pelo outro: medimos o tempo pelo movimento, mas também o movimento pelo tempo. Enquanto o movimento existe objetivamente, sem que pensemos nele usando nossa alma, o tempo não existe objetivamente, porque ele depende da alma de alguém para medir o movimento e, consequentemente, fazer existir o tempo. Para Aristóteles, o tempo é único porque se uma pessoa medisse o tempo de um movimento, o tempo marcado em seu relógio seria o mesmo tempo marcado no relógio de outra pessoa que medisse o mesmo movimento. 
Por muitos séculos, a teoria sobre o tempo de Plotino (203 d.C. - 270 d.C.) causou muitas influências. Plotino considerava o tempo não só como medida do movimento (como Aristóteles), mas também como algo absoluto, ou seja, que não dependia de alguma coisa. $\mathrm{O}$ tempo deixa de ser absoluto na alma quando o abstraímos inteligivelmente para fazermos medições, numerações e relações com ele. Plotino achava que o tempo não está no mundo físico, está na alma, pois nossas almas imitariam, lá do mundo das ideias de Platão, a eternidade, e a imagem imitada dessa eternidade seria o tempo da nossa alma, e como a alma está no mundo físico - porque somos nós que a possuímos e vivemos no mundo físico - a alma faz o mundo físico se temporalizar (tempo como movimento).

Essas foram as ideias filosóficas que mais influenciaram as teorias sobre o tempo na Antiguidade. Entretanto, durante a Idade Média, não tivemos o destaque da filosofia, mas sim da teologia, porque foi um período de dominação política e teológica. O foco mundial das grandes ideias deixava a cultura grega e passava para a cultura ocidental. Santo Agostinho (354 d.C. - 430 d.C.) é quem faz a primeira formulação fundamentalmente teológica sobre o tempo. Ele estuda o tempo como um fenômeno que se dá no espírito, não precisando, para isso, de um suporte cosmológico.

Agostinho, ao abandonar um suporte cosmológico do tempo e ao radicar a experiência do tempo no espírito por meio de signos (imagens-vestígio e imagens antecipantes), deixa de interessar-se pelo tempo físico e caminha na direção da reflexão sobre o tempo lingüístico. Com efeito, a linguagem não somente é a prova de que o argumento cético não subsiste, mas também é o que propicia ao homem a experiência temporal, na medida em que só quando o tempo é semiotizado pode o ser humano apreendê-lo e medi-lo. (FIORIN, 2008, p.139).

Santo Agostinho nos trouxe o caráter psicológico do tempo, ligando-o à consciência, com noções de anterioridade, localização, impressão do antes e do depois, etc.

Em Confissões (Cap.13 e 28 do Livro XI), explica como funciona o presente, o passado e o futuro. Ele diz que essas três facetas do tempo estão dentro da mente do homem. Dentro da mente podemos ter três sensações: espera (futuro), recordação (passado) e atenção (presente); quando sentimos uma espera, estamos lidando com o futuro, quando sentimos uma recordação, estamos lidando com o passado, e quando estamos atentos, estamos lidando com o presente. Qualquer uma dessas três sensações só existe enquanto existe, ou seja, enquanto são "presentificadas" na alma do homem. Sempre que medimos e processamos o tempo, fazemos isso no momento presente. Nesse sentido, podemos lidar com o passado na medida em que o "presentificamos" na forma de uma recordação. Assim, um evento que ocorreu na nossa infância é, em si, considerado um evento passado, na linha do tempo 
cronológica, mas ao falarmos desse evento da infância, fazemos essa recordação, que é uma sensação do passado, ser "presentificada". Considerar o evento da infância passado ou presente depende do ponto de vista; se alguém pensa sobre sua infância, ele faz com que a recordação se torne presente na sua alma, mas se ele se refere a sua infância como um fato isolado em si mesmo, é um passado, e não presente.

Nem o futuro nem o passado são (aqui, referindo mesmo ao verbo "ser" no presente). O que é é só o presente: presente do passado, presente do presente e presente do futuro. Para Santo Agostinho, tomamos por seres não o passado e o futuro enquanto tais, mas qualidades temporais que existem no presente. Este presente não pode ser medido porque não tem duração. É um tempo que não permanece e que não tem extensão, pois, se tivesse uma extensão, esta poderia ser dividida em um antes e em um depois. Portanto, é somente um ponto - o instante ou agora - que pode ser chamado de presente (XV, 20). Também não podemos medir o passado - porque não existe mais -, nem o futuro - porque não existe ainda -, e se achamos que podemos medi-lo é porque temos uma sensação de duração psíquica de passado e futuro, e, então, fazemos a medição dentro de um espaço mental de tempo. Para Santo Agostinho, o que temos de medidas temporais são impressões de tempo e não o tempo real.

As operações com o tempo na alma das pessoas, segundo Santo Agostinho, são feitas no presente, mas, como o presente é apenas um ponto, precisamos distender esse presente quando quisermos medir o tempo de algo presente, ou distender uma recordação do passado, para podermos medir o passado, ou distender a expectativa de algo, se quisermos medir o futuro. O tempo não seria outra coisa senão distensão. Poderíamos exemplificar essa distensão com a seguinte ilustração:

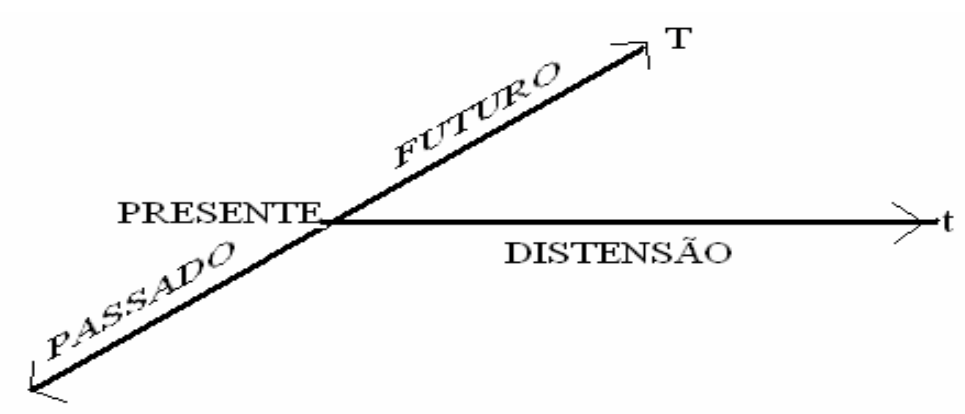

Figura 2 - Distensão de Santo Agostinho

A reta "T" representaria o nosso tempo cronológico e a reta " $t$ ", o tempo que é operado na mente do homem. O presente só tem extensão quando é "distendido" na mente, representando uma distentio animi, nos termos de Santo Agostinho. Se não o for, só poderá 
ser um ponto ${ }^{8}$ que divide o Tempo em passado e futuro. Para que essa distensão seja uma distensão do futuro, ela só poderá ser uma "expectativa" do futuro e, portanto, a distensão possível será um "presente do futuro". Para que seja do passado, busca-se na memória algum pensamento que será distendido no presente e, portanto, teremos uma distensão de "presente do passado".

Pode-se dizer, portanto, que se trata do ato enunciativo, que é aquele que transforma o tempo do mundo (passado, presente e futuro) em tempo da linguagem (o passado não é o passado, o presente não é o presente e o futuro não é o futuro), que é um tempo presentificado por meio do momento da enunciação. O segmento de reta $(\mathrm{t})$ ilustra o tempo que o homem opera em sua mente - é o tempo da enunciação - e o seguimento de reta (T) ilustra o tempo de que a linguagem se utiliza para a referência cronológica.

Santo Agostinho faz a distinção entre a temporalização e a aspectualização do tempo. A aspectualização do tempo é a medida do tempo da distentio animi, ou seja, o modo como a alma mentaliza (aspectualiza) algo a que se está atento, de que se lembra ou que se espera, já que, para Santo Agostinho, medimos o tempo pela consciência que temos dele. $\mathrm{O}$ ato enunciativo passa (transit) pelo tempo real do futuro ao passado, e esse movimento é a temporalidade para Santo Agostinho:

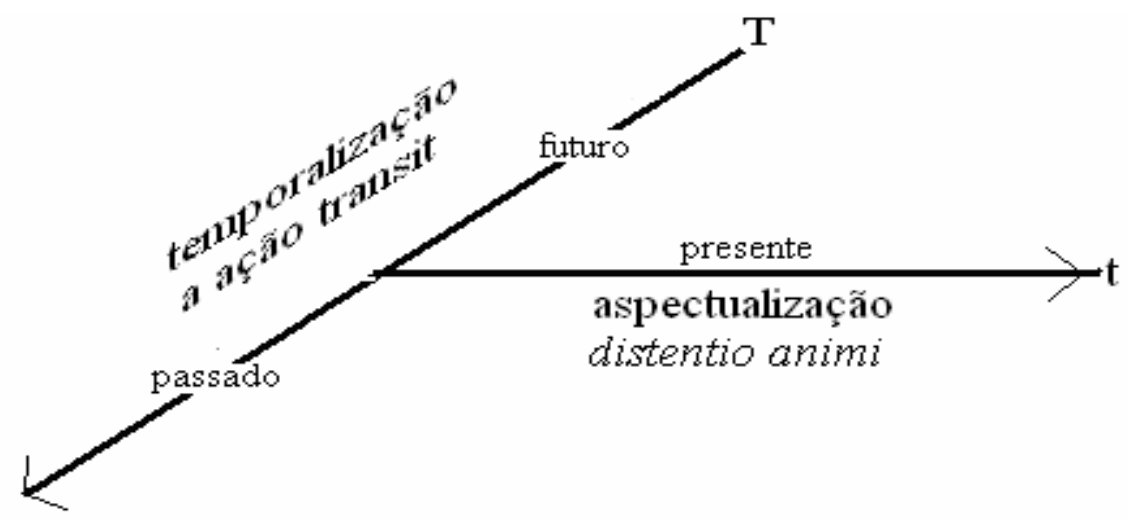

Figura 3 - Temporalização e aspectualização

Se pudermos entender que a alma a que se refere Santo Agostinho é da ordem do pensamento e pudermos afirmar que o pensamento é de natureza linguística, observaremos que o produto da reflexão da alma - um discurso - se dá sempre no presente. Esse paralelo entre uma concepção filosófica da alma e uma compreensão do mecanismo linguístico nos parece relevante, uma vez que "Observar-se-á que na realidade a linguagem não dispõe senão

\footnotetext{
${ }^{8}$ Este ponto pode ser localizado, na figura 2, pelo encontro das retas T e t.
} 
de uma única expressão temporal, o presente. [...] A língua deve, por necessidade, ordenar o tempo a partir de um eixo, e este é sempre e somente a instância de discurso." (BENVENISTE, 2006, p.75).

Chega-se ao fim da Idade Média. Galileo Galilei (1564 - 1642) funda a Física Moderna no início do século XVII. A Física Moderna não vai ficar apenas nas hipóteses (como a Física Aristotélica), pois ela precisa do confronto direto com a natureza por meio de experiências para confirmar suas hipóteses. É um saber a priori confirmado por um saber $a$ posteriori, um conhecimento materialmente físico e formalmente matemático.

O filósofo Pablo Mariconda (2008) disse que Galileu foi o primeiro a afirmar um tempo físico e a mostrar que havia um tempo natural que podia ser medido com instrumentos capazes de se movimentar de forma uniforme - os precursores dos relógios.

É importante distinguir o que o relógio realiza e o que o relógio representa. O relógio é um instrumento que mede a extensão do tempo, e não deve se confundir com o próprio tempo. Pensemos, por exemplo, numa partida de futebol. No início do primeiro tempo, pensamos que faltam 45 minutos para o seu encerramento, mas não podemos ter certeza. A dúvida permanecerá até que o jogo acabe, pois não poderemos cronometrar os 45 minutos que ainda não aconteceram. Se o que medíssemos fosse o próprio tempo, conseguiríamos medir algo futuro, que ainda não aconteceu. Quanto ao fenômeno espaço, isso não acontece, pois há como fazermos uma medição direta sobre ele. Por exemplo, em uma mesa, basta irmos deslizando uma régua pelo seu comprimento para sabermos até quanto vai o seu último centímetro; neste caso, a régua é um medidor de espaço que representa o próprio espaço, enquanto o relógio é um medidor de tempo que não é tempo, e para medir o final de um jogo precisamos esperar que os 45 minutos finais cheguem até nós.

Passado e futuro não são lugares a que possamos chegar a partir do presente. Como quer que sejam concebidas, as unidades do fluxo temporal não compartilham, como os pontos do espaço, da propriedade da concomitância. Existir simultaneamente seria negar a sua característica mais essencial, que é existir sucessivamente. (GIANNETTI, 2005, p.68, grifo nosso).

Galileu mostrou as diferenças entre um observador interno e um outro externo a um sistema em movimento. O movimento só pode ser caracterizado em função das coisas que não participam desse movimento. Essa teoria do movimento relativo é básica. Mais tarde, Einstein (1879-1955) irá colocar em hipótese o fato de um observador de um movimento também estar em movimento (ao invés do repouso de Galileu), especificamente, num movimento de viagem 
numa velocidade altíssima de $300000 \mathrm{~km} / \mathrm{s}$, e resultando em fatos diferentes dos afirmados por Galileu, criando, assim, avanços nos estudos sobre a relatividade.

Isaac Newton (1642 - 1727), por formular a lei da gravitação universal - a revolução científica do seu tempo - instaura a Mecânica Clássica. O físico admite a existência do tempo na ausência das coisas. O tempo absoluto, verdadeiro e matemático, por si e por sua própria natureza, flui uniformemente sem relação com nada externo, e é também chamado duração. "Dentro da concepção de Newton, se o Universo fosse congelado, o tempo continuaria a existir", disse o Historiador da Ciência Roberto Martins (2008). Para Newton, assim como para Aristóteles, o tempo era único, porque se uma pessoa medisse o tempo de um movimento, o tempo marcado em seu relógio seria o mesmo tempo marcado no relógio de outra pessoa que medisse o mesmo movimento. Para Newton, além de um tempo absoluto, também existiria um tempo relativo, que depende dos acontecimentos e que pode ser mensurado. Esse tempo relativo, aparente e comum é uma medida sensível e externa da duração, por meio do movimento, que é usada ao invés do tempo verdadeiro. Newton defendeu a existência de espaço e tempo absoluto, conceitos que foram úteis porque permitiram formular com clareza a física newtoniana, a mecânica e a astronomia, e foram aceitos pela maioria dos físicos, afirmou Martins (2008).

Para Newton, o tempo é independente das coisas, ou seja, enquanto as coisas mudam, o tempo não muda, e todas as coisas no Universo se moveriam juntamente e ao mesmo tempo; essa é a perspectiva global da física newtoniana.

O alemão Gottfried Leibniz (1647 - 1716) não admitia a existência do tempo na ausência das coisas, como admitia Newton. Portanto, não achava que o tempo fosse uma grandeza absoluta, mas, sim, relativa, porque dependia da existência de mudanças não simultâneas.

Para entendermos melhor a sua concepção relacionista do tempo, vamos novamente comparar o tempo com o espaço. Sabemos que dois corpos não ocupam o mesmo lugar no espaço porque precisam seguir uma ordem para existirem, e é comum essa ordem ser identificada pelos seres humanos, pois não ousamos ${ }^{9}$ colocar um par de chinelos dentro de uma caixa de sapatos onde já existe um par de sandálias. Com o tempo, acontece algo parecido. Enquanto tudo do mundo muda e se transforma simultaneamente, não há tempo, porque não há uma ordem de mudanças. Não diríamos, por exemplo, que primeiro a flor abre suas pétalas, e depois o botão desabrocha, mas sim que a flor abre suas pétalas enquanto o

\footnotetext{
${ }^{9}$ Com exceção dos bebês, que ainda não desenvolveram totalmente essa faculdade de percepção do espaço (PIAGET, 1975).
} 
botão desabrocha. Em outras palavras, não haveria tempo entre o abrir de pétalas e o desabrochar de um botão porque são movimentos simultâneos, e não movimentos ordenados um após o outro. Assim como o espaço exigiu que houvesse uma ordem de existências (um par de chinelos colocado ao lado e não dentro da caixa de sandálias) o tempo exige uma ordem de mudanças.

Do ponto de vista teológico, segundo Leibniz, a imensidade de Deus, conhecida por estar em todas as coisas, deve ser independente do tempo porque não há espaço para uma concepção de tempo numa existência onipresente que é Deus. Leibniz estudava o tempo como uma relação, uma ordem. O tempo seria a ordem da existência das coisas que não são simultâneas. Assim como é condição do espaço que uma coisa exista após a outra, numa ordem espacial, é condição da existência do tempo uma mudança suceder a outra, numa ordem temporal, pois, para Leibniz, assim como o espaço é uma ordem de coexistências, o tempo é uma ordem de sucessões. Mas sua teoria relativista do tempo não foi a mais defendida entre os físicos.

E foi assim, até começo do século XIX, que a Física se desenvolveu, acreditando, de modo geral, que o tempo fosse único, ou seja, o mesmo para qualquer observador.

Enquanto os físicos estudaram o tempo cientificamente do século XVI ao XIX, os filósofos o estudaram com os instrumentos do pensamento. Voltemos a falar dos estudos filosóficos. Temos a Filosofia Moderna, marcada com Descartes no começo do século XVII, e que se prolonga até a segunda metade do XIX. Foi uma filosofia cujo fundamento da certeza transfere-se do objeto para o sujeito, já que só existimos por recompensa a sabermos pensar Cogito ergo sum, "Penso, logo, existo", famosa e fundamental frase de Descartes. Em outras palavras, o lugar onde antes se buscava o fundamento para alguma certeza não é mais o objeto, mas um lugar construído a partir do sujeito.

Locke $(1632$ - 1704) e Berkeley $(1685$ - 1753) reduzem o tempo à ordem das idéias porque só as idéias poderiam ser os únicos objetos de que se podia falar.

Para Immanuel Kant (1724 - 1804), o tempo não existia na natureza. A percepção do tempo era uma criação subjetiva do homem e, portanto, os animais não teriam a noção de presente, passado e futuro. Entretanto, “[...] o tempo pode ser considerado real, porém não como objeto, mas como forma de representar [...]" (KANT, 1964, p.140 apud ASKIN, 1969, p.33), e este é o lado objetivo da sua concepção de tempo. O tempo, segundo Kant, é a ordem das percepções das mudanças, mas não das mudanças em si. Kant reduziu essa ordem de sucessões à ordem da causalidade e disse que "[...] é condição formal de todas as percepções que o tempo anterior determine necessariamente o seguinte [...]" (KANT, 1964, p.140 apud 
ASKIN, 1969, p.33). Kant não negava a existência objetiva das coisas, não negava o mundo exterior, mas entendia que o tempo, assim como o espaço, eram formas de percepção sensorial, independente dos próprios objetos, e que não refletiam as propriedades das coisas em si; o tempo nada mais seria senão a condição subjetiva sob a qual podem ocorrer em nós todas as intuições.

Mais tarde, Pavlov (1849 - 1936), fisiólogo russo, com suas investigações por meio de reflexos salivares condicionados nos cães, provou, utilizando métodos da ciência natural, que o tempo é uma realidade objetiva, pois as formas temporais da psique constituem um reflexo dos traços temporais do mundo material. Isso tudo derruba a tese kantiana de que o tempo fosse algo exclusivamente vinculado ao sistema cognitivo do homem, dos seres pensantes.

Para Hegel (1770 - 1831), a razão não é somente objetiva (a verdade está nos objetos) nem somente subjetiva (a verdade está no sujeito), mas representa uma unidade do objetivo e do subjetivo. Hegel diz que o presente é o único conceito que pode existir. O agora é um quase-objeto instantâneo, suspenso entre dois nadas, uma vez que passado e futuro, segundo ele, não existem. O filósofo expõe a negatividade constitutiva do tempo: o tempo é ser, que, sendo não é e, não sendo, é.

Até este momento, a Filosofia transladou alguns conceitos fundamentais demonstrados pela Física do século XVI ao XIX, ou seja, rejeitou a esfera do campo experimental para adotar ideias a priori. Nesse intervalo de tempo, a Física, até então, era newtoniana, depois que Newton formulou a lei da gravitação universal que permitiu fundamentar a física em um princípio único, de grande amplitude ou generalidade. Com os avanços dos aparatos de análise física, pôde-se sair das dimensões da Terra e ir para as do Universo. Quando os físicos fizeram isso, tiveram que dizer mais coisas e até desdizer outras ditas até o século XIX, pois, com esses avanços, eles perceberam que não há no Universo um ponto de referência que permita comparações absolutas, como se achava na física Newtoniana.

Vejamos o que aconteceu na Física do século XX e depois voltaremos para os estudos de Filosofia do século XX.

Einstein (1879-1955) criou a Teoria da Relatividade Restrita (TRR) utilizando a descoberta do físico escocês James Clerk Maxwell (1831-1879) que viu que a velocidade da luz parecia a mesma a todos os observadores, independentemente do deslocamento de cada um, fosse qual fosse a velocidade da fonte, e isso foi confirmado por mensurações precisas. Essa simples questão teve como consequência, dentre outras coisas, a revolução dos nossos conceitos de tempo e espaço. 
Na teoria de Newton, se uma vibração de luz é enviada de um lugar a outro, observadores diferentes deverão concordar quanto ao tempo gasto na trajetória (uma vez que o tempo é absoluto), mas nem sempre concordarão sobre a distância percorrida pela luz (uma vez que o espaço não é absoluto). Dado que a velocidade da luz é apenas a distância que ela percorre, dividida pelo tempo que leva para fazê-lo, diferentes observadores poderão atribuir diferentes velocidades à luz. Segundo a teoria da relatividade, por outro lado, todos os observadores deverão concordar quanto à rapidez da trajetória da luz. Podem, entretanto, não concordar com a distância percorrida, tendo então, que discordar também quanto ao tempo gasto no evento. (HAWKING, [1989], p.33).

Podemos explicar essa questão por meio de um exemplo com dados numéricos. Diremos que, segundo a teoria de Newton, se um objeto fosse de um ponto A a um ponto B, e se dois observadores, por exemplo, João e Pedro, medissem o tempo que o objeto levou para ir de um lado para outro, eles, de acordo com Newton, deveriam necessariamente ter medido o mesmo intervalo de tempo, exemplo, $5 \mathrm{t}$, onde $\mathrm{t}$ seria uma unidade de medida de tempo ${ }^{10}$. João e Pedro poderiam discordar sobre a distância percorrida por esse objeto, pois, se João estiver parado em relação ao objeto, ele pode dizer que a trajetória de A até B tem 1000S, onde S seriam unidades de espaço, por exemplo. Isto significa que ele vê o objeto se mover a uma velocidade de $200 \mathrm{~S}$ por t, já que a velocidade de um corpo é igual a distância percorrida por esse corpo dividida pelo tempo que ele levou para percorrê-la, e, portanto, $V=S / t-V=1000 / 5$ - V=200. Mas, se Pedro não ficasse parado observando o movimento do objeto como João ficou, ele pode discordar de João sobre o espaço de A a B ser de 1000S. Isso aconteceria se Pedro também estivesse se movimentando no mesmo sentido em que o objeto se movimenta de A a B. Se Pedro estiver se movimentando junto com o movimento, mas a uma velocidade menor, ele poderá medir a trajetória do objeto, em relação à sua, como um trajeto de 500S. Pedro também, com isso, discordará de João quanto à velocidade, porque, para ele, o objeto passará mais devagar, a uma velocidade de $100 \mathrm{~S} / \mathrm{t}$, pois $\mathrm{V}=\mathrm{S} / \mathrm{t}-\mathrm{V}=500 / 5-\mathrm{V}=100$.

Com a descoberta de que a luz viaja a uma velocidade sempre igual para todos os observadores em movimento livre, não importando qual fosse a velocidade de cada um, e se o objeto que fosse medido na experiência que exemplificamos acima fosse uma vibração de luz a percorrer a trajetória de $\mathrm{A}$ a $\mathrm{B}$, as contas feitas acima deveriam sempre manter a velocidade (V) constante, e isso não ocorreu no nosso exemplo. Se João e Pedro marcassem o tempo da trajetória de uma vibração de luz de A até B, veriam a luz correndo a uma mesma velocidade, e ninguém veria a vibração mais lenta ou mais rápida que o outro, porque a velocidade da luz é constante. Como João vê em uma trajetória de 1000 unidades de espaço uma vibração correr

\footnotetext{
${ }^{10}$ Consideramos que seria mais simples não colocar unidades de medida do dia a dia no nosso exemplo.
} 
a $200 \mathrm{~S} / \mathrm{t}$, por exemplo ${ }^{11}$, então o tempo gasto pela vibração de luz de A a B é de $5 \mathrm{t}$ em seu relógio pois $\mathrm{V}=\mathrm{S} / \mathrm{t} ; 200=1000 / \mathrm{t} ; \mathrm{t}=1000 / 200 ; \mathrm{t}=5$. Como Pedro vê em uma trajetória de $500 \mathrm{~S}$ uma vibração percorrer de A a B a uma velocidade também de $200 \mathrm{~V}$ (porque a velocidade da luz é fixa), então, no seu relógio, a vibração de luz vai demorar 2,5t ao invés de $5 \mathrm{t}$ do João, pois $\mathrm{V}=\mathrm{S} / \mathrm{t} ; 200=500 / \mathrm{t} ; \mathrm{t}=500 / 200 ; \mathrm{t}=2,5$. Assim, mostra-se que um mesmo evento pode ter uma cronometragem diferente entre dois observadores quando, por exemplo, esse evento a ser medido atinge altíssimas velocidades.

Einstein consegue provar, com sua Teoria da Relatividade Restrita, que o tempo não é único e absoluto. Em vez disso, cada observador teria sua própria medida de tempo, ou o seu próprio relógio, que não precisa concordar, necessariamente, com o que registra o relógio de outro observador. Se um relógio registra a duração de um evento com um número x, e este número não é o mesmo registrado pelo relógio de outra pessoa, então o tempo não é único e absoluto, mas passa a ser relativo; relativo a outras questões necessárias à medição do tempo, como o espaço em que o movimento se dá e em que o evento ocorre.

Por outro lado, Einstein e os físicos, de modo geral, admitem que essa descoberta - a do tempo não ser absoluto -, não altera nossas vidas e nossas noções comuns, ou seja, se nossos relógios estiverem sincronizados, não vai acontecer de algum dia discordarmos de alguma medição de algum movimento que presenciarmos, porque não temos a capacidade de perceber objetos que se movem a uma velocidade de $300.000 \mathrm{~km} / \mathrm{s}$, que é a velocidade da luz, nem viajar a essa velocidade.

Entretanto, embora não necessitemos das considerações da Teoria da Relatividade Restrita para concordar uns com os outros quanto ao tempo dos nossos relógios físicos, o tempo dos nossos relógios biológicos - a mente e o corpo de cada ser - é bastante pessoal e, por isso, bastante relativo a cada ser humano. Prova disso é, por exemplo, o processo do envelhecimento, as nossas sensações como quando percebemos o passar de uma manhã, que pode ser longa para alguns e curta para outros, ou a lembrança da própria infância que pode ser sentida como mais próxima ou mais distante do ponto atual da vida de cada pessoa. A experiência individual, social e cultural interfere na percepção do tempo.

Outra questão relativa pode ser observada no mundo físico. Os feixes de luz que nos iluminam não nos atingem instantaneamente, porque se leva um tempo para que as vibrações de luz saiam da fonte que as gerou e cheguem até nós. Para vermos o Sol, por exemplo, é preciso 8 minutos para que tenhamos a percepção do seu brilho. Se uma filha pergunta a sua

\footnotetext{
${ }^{11}$ Suponhamos que $200 \mathrm{~V}$ corresponda à verdadeira velocidade da luz.
} 
mãe: Mãe, o sol existe? A mãe pode responder: Não sei filha, até a uns 8 minutos atrás com certeza ele existia, porque ele está lá fora agora!

A sensação de instantaneidade das nossas certezas sensíveis não passa, no fundo, de uma construção dos sentidos - uma ilusão simplificadora. Pois o fato é que existe sempre uma defasagem de tempo, com duração variável mas valor necessariamente positivo, separando o que é, de um lado, e aquilo de que chegamos a nos dar conta, de outro. [...] o agora vivido é inescapavelmente passado. (GIANNETTI, 2005, p.143).

Já se conjecturou ${ }^{12}$ que se poderia revisitar visualmente o passado, se alguém se situar em algum lugar do Universo, bastante distante da Terra, e observá-la por um telescópio: seria possível presenciar de novo qualquer evento já ocorrido no passado. Isso significa que o que chamamos de presente depende do lugar que ocupamos no espaço.

Quando olhamos o Universo, nós o estamos olhando como ele era no passado. O que vemos teve um tempo para estar como está, e esse tempo dependerá do lugar onde está o que vemos, portanto, o espaço precisa do tempo e o tempo do espaço. O tempo está imbricado no espaço. Observadores que estejam se movendo, com velocidades diferentes, uns em relação aos outros, irão registrar tempos e posições diferentes para o mesmo evento. Portanto, quando se leva em consideração esse tipo de relatividade, as noções de passado, presente e futuro passam a depender de uma percepção.

Por outro lado, assim como não precisamos da Teoria da Relatividade Restrita, porque não fazemos experiências com velocidades maiores que a da luz, também não precisamos, de modo geral, da relatividade dos elementos iluminados pela luz, pois não levamos em conta essa questão no nosso dia a dia, uma vez que se convencionou dizer que as estrelas que vemos são (e não eram) as estrelas que vemos agora, e, ainda, dizer que o mundo e o Sol que olhamos são aqueles que olhamos agora.

O palco das nossas vidas, formado de quatro dimensões - porque o tempo toma as três dimensões do espaço e as soma com a sua -, até 1915, foi considerado como um palco fixo onde todas as coisas do Universo atuavam. Depois da Teoria Geral da Relatividade, Einstein disse que o próprio espaço-tempo se modifica como dependência do movimento dos corpos.

No século XX, com a teoria da Mecânica Quântica, fala-se, então, de tempo real e de tempo imaginário. O tempo real é o simples tempo de que a ciência vinha explorando, e o tempo imaginário é uma nova ideia introduzida pela Mecânica Quântica.

\footnotetext{
${ }^{12}$ Cf. LIGHTMAN, Alan. Viagens no tempo. 1999. p.44 apud GIANNETTI, 2005, p.144-145.
} 
Quando se tenta unificar a gravidade com a mecânica quântica, temos que introduzir a idéia do tempo "imaginário", que é indistinguível do conceito de direções no espaço. Se podemos ir para o norte, podemos também voltar e nos dirigirmos para o sul; da mesma maneira, se podemos ir em frente no tempo imaginário, devemos ser capazes de voltar atrás. Isso significa que não há diferença significativa entre as direções para a frente e para trás no tempo imaginário. (HAWKING, [1989], p.143).

Essa reversibilidade do tempo, proposta pelo tempo imaginário, não acontece no nosso dia a dia, pois há grande diferença entre passado e futuro para nós, em termos de pressuposição lógica. Com a Física Quântica temos possibilidades e não mais certezas. Por esse motivo, costuma-se dizer que a Física nunca esteve tão "mística" como no século XXI.

As teorias da Física do século XIX e XX não foram todas levadas em consideração pelos estudos Filosóficos:

[...] nos séculos XIX e XX a ciência se tornou muito técnica e matemática para os filósofos ou qualquer outra pessoa além dos poucos especialistas. Os filósofos reduziram tanto o escopo de suas indagações, que Wittgenstein, o mais famoso pensador deste século, declarou: "A única tarefa que sobrou para a filosofia foi a análise da linguagem". Que decadência da grande tradição de filosofia de Aristóteles a Kant! (HAWKING, [1989], p.169).

Na filosofia do século XX, surgem as teorias de Bérgson, Husserl e Heidegger. Henri Bérgson (1859-1941) critica o tempo da ciência, ou seja, o tempo da física, porque o considera forjado cientificamente pelo homem. O tempo verdadeiro para Bérgson é o tempo da nossa consciência, da nossa mente. Bérgson critica a concepção de tempo de Einstein porque o físico "espacializa" o tempo, ou seja, faz o tempo depender do espaço para analisá-lo e medilo. O tempo que a Física mede é uma trajetória espacial de um movimento convertido em tempo mensurável. Para Bérgson o tempo não pode ser analisado, porque é uma realidade abstrata, e não pode ser medido, porque a duração é um dado apreendido pela nossa consciência subjetiva, um objeto da intuição.

Bérgson acreditava que todos os filósofos, desde que conceberam o tempo junto ao espaço, acabaram "espacializando" o tempo. Ele rejeitou o espaço e trabalhou para que houvesse distinção entre tempo verdadeiro e tempo falsificado, ou seja, lutou para que não misturássemos o objeto da física (tempo cronológico) com o objeto tempo da nossa intuição. O filósofo segue as ideias de tempo de Santo Agostinho porque também entende que o tempo seja um prolongamento da alma, a qual Bérgson chama de vida interior, e que se confunde com a memória. Sua argumentação para defender que o tempo verdadeiro fosse algo que se confundisse com a memória é a de que sem a memória não teríamos a consciência de uma 
ligação entre um antes e um depois de um evento real. Segundo o filósofo, se não tivéssemos a consciência da duração de uma realidade, não teríamos noção alguma de tempo. De fato, se nós observarmos, por exemplo, uma xícara cheia de café e, depois de certo tempo, observarmos, na realidade empírica, a mesma xícara vazia de café, sem uma memória não iremos dizer que alguém tomou o café da xícara, ou que alguém derrubou o café ou mesmo que o café se evaporou, porque não saberíamos que segundos antes havia café na xícara, uma vez que não lembraríamos de tê-la visto com café.

Em resumo, o tempo verdadeiro é, para Bérgson, uma linha móvel dentro da mente, um devir, o desenrolar da vida. Esse tempo como um incessante devir impediria de haver no mundo e na mente puros instantes, mas permite haver sempre prolongamento do antes no depois, devido a um presente (um instante de presente) que apareceria e desapareceria, renascendo sem cessar.

Edmund Husserl (1859-1938) também pensa como Santo Agostinho. Ele considera o tempo um contínuo infinito de durações, durações de experiências vividas, pois, para Husserl, só conseguimos tratar das realidades que foram vividas por nós, porque para tratar de uma realidade é preciso pensá-la. A alegria, por exemplo, é uma experiência vivida que, considerada isolada, possui uma duração, com começo e fim, mas a corrente das experiências é um contínuo sem interrupções, pois após um momento alegre, sucede um momento triste, e assim sucessivamente. É interessante pensar que a alegria só existe porque existe um momento de tristeza que o antecede. Nesse sentido, o tempo, ou melhor, a sua fugacidade, é quem atribui valor e sentido às coisas e à nossa vida.

Martin Heidegger (1889-1979) estudou o tempo sob dois pontos de vista: o do homem e o ontológico. Em Ser e tempo, de 1927, diz que o tempo é uma estrutura da possibilidade porque sua concepção do tempo fundamenta-se sob a perspectiva do futuro. Ele percebe que o futuro de que comumente falamos é o que já passou, porque as nossas escolhas são escolhas do já escolhido, isto é, da impossibilidade de escolher. Deve ser por isso que Santo Agostinho chama o futuro de futuro do presente (e o passado, chama de passado do presente, e o presente, de presente do presente), pois, como afirma ser o presente do futuro uma expectativa do futuro, então o que se espera já está esperado. Esse tempo “já esperado”, para Heidegger, seria o tempo natural, vulgar, que ele chama de intratemporalidade. O que Heidegger inovou foi tratar do futuro como futuro, tentando dizer o que ele seja filosoficamente. Disse que o tempo é um "vir a ser". Esse é o modo de ver o tempo no domínio do ontológico, do ser fora de si e este é o tempo da extratemporalidade. O tempo para Heidegger é o agora que ainda não se tornou atual, e por isso ele pode ser todas as possibilidades de coisas. Dessa forma, o 
tempo não é mais reduzido a uma estrutura necessária, composta por uma ordem causal, mas é ampliado em algo que representa a própria estrutura da possibilidade. Para Heidegger, o tempo é o "estar durando" e não a duração; a duração, o subjetivismo apreende; o "estar durando", ou seja, o próprio tempo ontológico existe fora da duração.

Poderíamos relacionar a teoria do tempo da intratemporalidade de Heidegger com, por exemplo, a teoria do tempo de Aristóteles, de Santo Agostinho, a teoria do tempo verdadeiro de Bérgson, etc., e, com isso, obter muitas aproximações teóricas. Mas a teoria do tempo da extratemporalidade pareceu-nos única, ao longo da revisão de literatura. Heidegger foi um dos poucos filósofos a conseguir pensar o tempo abstraindo a influência que a própria ordenação do nosso cérebro causa ao pensar sobre esse fenômeno. Podemos dizer que esse tempo "extratemporal” é um tempo abstraído de uma concepção linguística, um tempo que foi refletido sem usar o pensamento. Em outras palavras, a intratemporalidade é a consciência do tempo, enquanto a extratemporalidade é o tempo que não foi tomado pela consciência.

A teoria do tempo de Santo Agostinho parece-nos estar fundada sob as condições da enunciação: a resposta para o que seja passado, presente e futuro estaria relacionada com o momento atual do ser pensante, à medida que este ou tem uma expectativa (futuro), ou uma recordação (passado), ou uma atenção (presente). Por isso, o futuro, o passado e o presente são sempre concepções sobre a perspectiva do presente, pois o ser pensante precisa sempre estar estabelecido num momento presente, num ponto fixo do tempo. Essa maneira de ver o homem aparentemente imóvel dentro de um "eterno" presente parece estranha, uma vez que a característica mais natural e conhecida do tempo é a sua mobilidade, mas essa aparente estabilidade do ser pensante em um eterno presente se deve a sua capacidade humana de enunciar, pois é por meio da enunciação que acontece o ato de tornar presente cada instante significativo. Contudo, só o homem é capaz de enunciar. Se não pensamos na perspectiva do homem, e pensamos na perspectiva ontológica do tempo, temos que achar outras explicações para o que seja passado, presente e futuro.

Heidegger (1927) procurou pensar o tempo entendido não só na perspectiva do homem, mas fora dela. Procurou entender o que era o futuro, o passado e o presente como termos puros filosoficamente, e não aqueles dependentes da mente humana, que devem ser chamados (na sua terminologia) de futuro, passado e presente "vulgar", ou "natural", ou "intratemporal". 


\section{3 - Um modelo geral do tempo do mundo real}

Depois que analisamos algumas teorias sobre o tempo na física e na filosofia, construímos uma possível ilustração do tempo concebido pelo homem. Para isso, não utilizamos o conceito de tempo como eternidade no mundo das Ideias de Platão, nem o conceito de extratemporalidade de Heidegger, nem o conceito de tempo imaginário da Física Quântica, porque eles pertencem a domínios que geralmente não são necessários dentro das questões do mundo cotidiano em que vivemos. Queremos pensar em um tempo real simples, que todos "vemos" e "sentimos" passar. Para isso, trabalhamos com a intratemporalidade heideggeriana, com o mundo sensível platônico, ou seja, trabalhamos sobre um tempo reduzido a uma estrutura necessária composta por uma ordem causal. Alguns autores citados serão retomados ao longo dessa Dissertação, conforme formos percebendo semelhanças entre teorias linguísticas e teorias físicas e filosóficas.

Podemos resumir dizendo que o tempo é o nome que se dá a um suporte metaforicamente espacial em que interpretamos os eventos, dispondo-os em uma relação de passado, presente e futuro. A natureza desse suporte, entretanto, é explicada pelos dicionários por meio de metáforas, pois é muito difícil explicar o que pode ser o tempo. Não conseguimos ouvir, cheirar, tocar, ver ou provar o tempo, mas não duvidamos de que ele exista.

A explicação mais encontrada nos dicionários a respeito da natureza desse suporte é a de que o tempo é "feito de" duração, e que nós sentiríamos (com os sentidos da alma) a duração das coisas porque sentiríamos as coisas: alegria, tristeza, duração de uma dor, a duração de uma infância, a duração de um jogo de futebol. Com isso percebemos que é mais fácil entender o tempo pelo termo duração do que pelo termo tempo. Ainda assim, a duração não é uma questão muito simples. Por exemplo, nos estudos de Fonética e Fonologia, há discordâncias sobre a percepção de um falante sobre a duração de segmentos fonéticos.

A forma geométrica que vamos utilizar para descrever o tempo é a reta. Gostamos da forma de "linha" por ser a linha do tempo uma das metáforas mais comuns do tempo.

Resumidamente, podemos pensar em duas classes de tempo do mundo real: o tempo objetivo e o tempo subjetivo. O tempo objetivo seria aquele observável a partir de mudanças na natureza, e se identificaria com a concepção de temporalidade de Santo Agostinho ilustrada na linha (T) da figura 3. Como vimos, o fisiólogo Pavlov provou que há um reflexo do tempo objetivo do mundo na nossa psique (e na psique dos animais também), ou seja, o 
tempo objetivo aqui não se confunde com o tempo "extratemporal" de Heidegger, porque, ainda que objetivo, ele é concebível pela psique humana, e, então, faz parte da intratemporalidade heideggeriana.

O tempo subjetivo seria a concepção psíquica, de forma ordenada, que fazemos quando refletimos sobre o tempo objetivo. Uma imagem clássica do tempo subjetivo seria uma linha onde disporíamos da esquerda para a direita as noções de passado, presente, e futuro, e sua direção seria crescente do passado para o futuro:

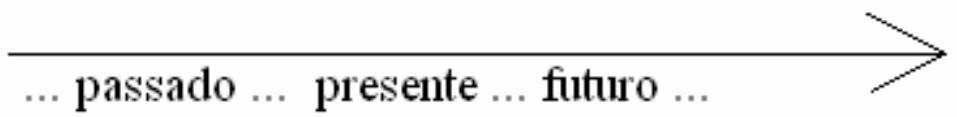

Figura 4 - Tempo subjetivo

E por que não hesitaríamos em aceitar essa imagem? Porque medimos o tempo convencionalmente na mesma direção do aumento da desordem, ou entropia. Hawking (HAWKING, [1989], p.144) explica que os físicos utilizam a $2^{\mathrm{a}}$ lei da termodinâmica para explicar a direção em que medimos o tempo. ${ }^{13}$ Essa lei afirma que em qualquer sistema fechado a desordem, ou entropia, sempre vai aumentar com o tempo porque há sempre muito mais estados de desordem do que de ordem. Por exemplo, se considerarmos como "sistema fechado" uma caixa fechada com um quebra-cabeça montado dentro, notaremos que quanto mais sacudimos a caixa, mais as peças ficam desarranjadas no interior da caixa. Esse seria o estado de entropia ou desordem, pois há mais estados de desordem na disposição das peças de um quebra-cabeça do que estados de ordem, uma vez que para qualquer jogo de quebracabeça, há um único estado de ordem, que é quando se forma com as peças a figura original, completando todo o quadro inicial.

Essa $2^{\text {a }}$ lei da termodinâmica é um exemplo de direção, ou seta, do tempo porque ela distingue o passado do futuro. "O aumento da desordem ou entropia através do tempo é um exemplo do que se chama uma seta do tempo, algo que distingue o passado do futuro, dando uma direção ao tempo.” (HAWKING, [1989], p 144). Nas palavras do físico, “A desordem aumenta com o tempo porque se mede o tempo na direção em que a desordem aumenta. Não se pode fazer afirmação mais segura do que essa!" (HAWKING, [1989], p.147).

Para termos outro exemplo, vamos imaginar duas imagens, A e B. Em A, uma xícara quebrada no chão está em desordem; em B, uma xícara intacta em cima da mesa está em ordem. Nosso conhecimento de mundo nos diz que a figura B antecede a figura A, porque o

\footnotetext{
${ }^{13}$ A lei da entropia explicaria, entre outras coisas, a teoria do Big-Bang. Entretanto, devemos nos lembrar que existem outras teorias sobre a formação do Universo, como, por exemplo, a teoria do caos.
} 
contrário nunca é observado na vida cotidiana; logo, esse exemplo segue a $2^{\text {a }}$ lei da termodinâmica, porque temos um estado de ordem (imagem B) passando para o estado da desordem (imagem A), fazendo com que vejamos B como passado de A.

Não só no mundo das xícaras que caem, mas no mundo de todos os objetos e seres vivos, opera-se o tempo da termodinâmica: as horas do relógio aumentam do passado para o futuro, mesmo que tenhamos um desses curiosos relógios que giram em sentido anti-horário, a numeração ao redor dele também estará disposta de tal forma que os ponteiros percorrerão os números em ordem crescente, do 1 ao12.

A nossa memória também é como as xícaras, também funciona de modo a distinguir o passado do futuro, porque só conseguimos nos lembrar de fatos passados. Sentimos que o tempo está passando ao nosso redor ao lembrarmos do passado e não do futuro, por isso há uma direção, uma seta psicológica do tempo, e o que nos recordamos é algo que vivenciamos, e o que vivenciamos nesse mundo são experiências regidas pela termodinâmica. Ou seja, vivemos experiências que também seguem essa "linha" do passado ao futuro. Aliás, segundo Hawking, a direção dessa seta é necessária para o funcionamento da vida inteligente, que se dá na direção do tempo da termodinâmica, porque para nós usarmos nossa inteligibilidade sobre o mundo, precisamos sobreviver sobre o mundo, e para sobrevivermos devemos consumir alimentos, que são formas ordenadas de energia, e converte-los em calorias, formas desordenadas de energia, ou seja, para pensarmos, precisamos agir metabolicamente, e isso requer tempo.

O cérebro é um instrumento registrador que se relaciona com o meio-ambiente: quando ativamos nosso cérebro, ordenamo-lo e dissipamos energia (caloria) desordenando o mundo com ela (suor). O neurocientista Martins Cammarota (2008), estudioso do funcionamento da memória, também afirma que nossa concepção de tempo é dada graças à nossa memória, ou seja, à nossa capacidade de registrar os acontecimentos. Isso nos faz considerar o tempo como algo contínuo que flui em uma única direção, para o futuro, e que a forma como interpretamos o mundo está intimamente relacionada com a noção de continuidade temporal.

Portanto, temos sempre em mente esse tempo "passado $\rightarrow$ futuro" ao falarmos de tempo, porque a nossa linguagem também está articulada temporalmente com ele. "Nosso senso subjetivo de direção do tempo, a seta psicológica do tempo, é, portanto, determinado dentro de nosso cérebro pela seta termodinâmica do tempo.” (HAWKING, [1989], p.147).

Alguns físicos acreditam que o Universo esteja se expandindo mais do que se contraindo. Usando o mesmo princípio da entropia, pode-se criar outra seta com mesma 
direção da seta subjetiva, a cosmológica. Com esta, existem, pelo menos, três setas do tempo, para Hawking:

1- o tempo da termodinâmica, que aumenta da ordem para a desordem;

2- o tempo da psique, que passa do passado para o futuro (pois nos lembramos do passado e não do futuro);

3- o tempo do cosmo, que aumenta da contração para a expansão.

Hawking explica que o Universo do qual fazemos parte, isto é, o Universo dos seres inteligentes, tem essas três setas apontando para a mesma direção. Ou seja, considerar a entropia como ordenação do Universo, no nosso caso, parece ser o melhor a fazer porque o que nos interessa é estudar o tempo da linguagem humana, e o homem a ser estudado por nós precisa ser dotado de inteligência.

Quando tentamos pensar outra forma de ver o tempo que não seja a forma subjetiva, temos que fazer um grande esforço para abstrair primeiramente o nosso senso subjetivo de direção do tempo, uma vez que estamos condicionados a pensar o tempo como indo do passado para o futuro.

Para a construção de uma ilustração do tempo objetivo, voltemos a fazer algumas considerações. Quando nós pensamos sobre um movimento, estamos passando rapidamente de um futuro para um passado. O agora seria um "ligador" do tempo, o que faz o posterior ser anterior, mas esse tempo que é "ligado" não é nem a posterioridade nem a anterioridade, é um tempo percebido pela alma e, como a alma está unida ao corpo e o corpo flui com o tempo, a alma também está submetida ao fluxo temporal. Em outras palavras, em um mundo objetivo, sabemos que temos um futuro e um passado, mas só podemos estar no instante presente, presenciando o futuro se tornando passado a cada instante. Como isto se dá de forma instantânea, temos apenas os segmentos de futuro e passado. Se o movimento de atualização das possibilidades é desse futuro para o passado, temos uma seta, ou vetor ${ }^{14}$, cuja direção é do futuro para o passado:

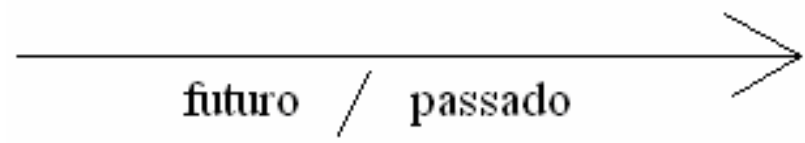

Figura 5 - Tempo objetivo orientado para a direita

E, ainda, se quisermos manter a ordem linear dos vocábulos "passado", "presente" e "futuro" que utilizamos na figura 4, só precisamos inverter a figura 5, de forma espelhada:

\footnotetext{
${ }^{14}$ Uma seta pode ser entendida como um vetor, ou seja, um segmento de reta orientado.
} 


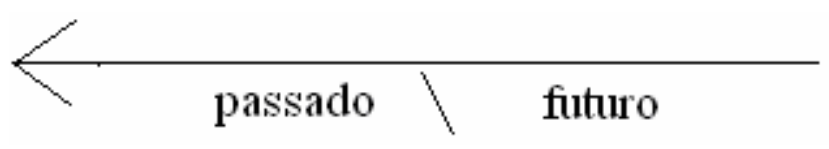

Figura 6 - Tempo objetivo orientado para a esquerda

O tempo, enquanto realidade objetiva observável no mundo, estaria se movimentando do futuro para o passado, isto é, o fato de os seres humanos acumularem ao longo da vida muitos passados se deve ao fato de que muitos futuros vieram até nós, passaram por nós e se transformaram em passado. Ou seja, somamos experiências passadas, e, consequentemente, envelhecemos, porque o futuro se move em nossa direção, e não para fora de nós.

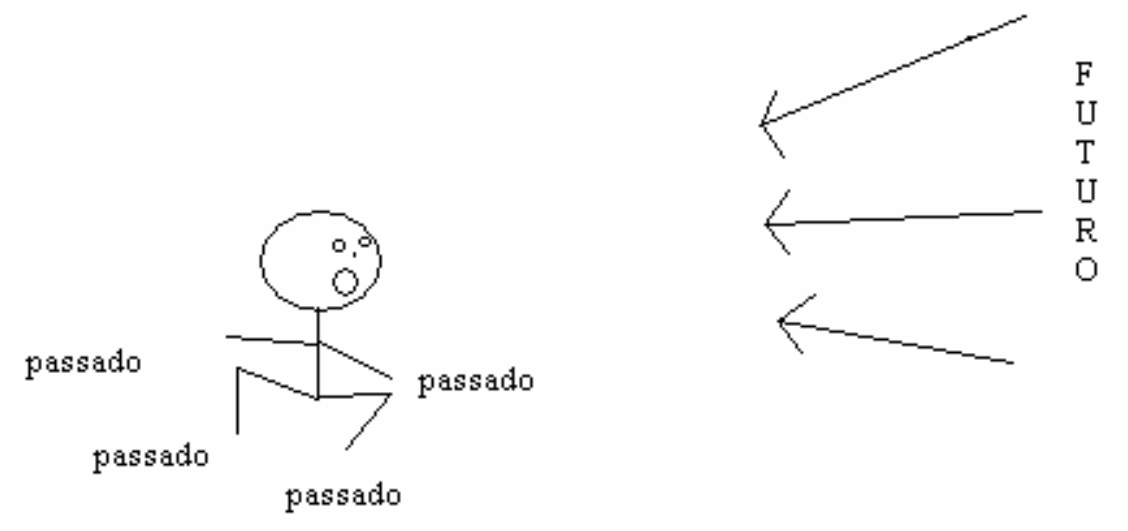

Figura 7 - O acúmulo de "passados"

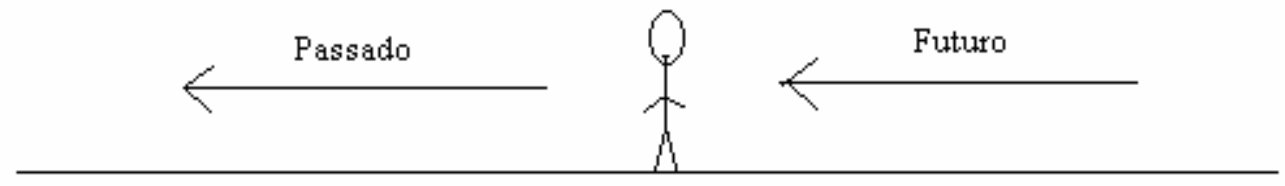

Figura 8 - A passagem do tempo pelo homem

Nessas ilustrações 7 e 8, o futuro se move em nossa direção; do contrário, se o tempo partisse de nós, saísse para fora de nós, rejuvenesceríamos cada dia um pouco mais. Nesse sentido, podemos construir uma seta objetiva do tempo, em que ele flua do futuro para o passado, à semelhança da figura 6. O tempo objetivo, como vimos em Pavlov, não depende apenas do ser humano para existir, pois os animais conceberiam uma movimentação das coisas indo de um futuro para um passado.

Uma grande diferença que podemos perceber, logo ao construir uma imagem desses dois conceitos de tempo, está na contrariedade das suas direções: enquanto a seta do tempo 
subjetivo flui do passado para o futuro (figura 4), a seta do tempo objetivo flui do futuro para o passado (figura 6).

Dissemos que é difícil entender o tempo objetivo porque é difícil desconsiderar o nosso senso subjetivo do tempo, mas há um teste simples que podemos fazer para sentir a diferença entre eles, ou ao menos acreditamos que este teste possa trazer uma intuição da diferença no modo como "experimentamos" esses dois tempos. O teste consiste, em uma primeira etapa, em nos sentarmos, em silêncio, por três minutos; ao fazermos isso, repararemos que a nossa sensação quanto a esses três minutos que passaram será de eles terem sido longos e entediantes. Provavelmente, enquanto esses minutos passam, nos preocupamos com questões do tipo: o que eu vou almoçar hoje? Por que eu tenho que ficar parado aqui por três minutos? O que eu estava fazendo mesmo, antes de vir para cá? Essas relações de passado, presente e futuro feitas com o tempo só existiriam porque estaríamos, durante esses três minutos, imersos num tempo contínuo, ou seja, com uma sequência de passado, presente e futuro.

Numa segunda e última etapa, o teste consiste em nos sentarmos novamente por mais três minutos, mas, ao contrário do silêncio anterior, ficarmos ouvindo uma música muito prazerosa, de que gostamos muito, a ponto de esquecermos tudo ao nosso redor, e nos mergulharmos profundamente na sua harmonia. Certamente sentiremos os três minutos passarem bem mais rápidos do que sentiremos passar na primeira etapa, porque, na verdade, praticamente não sentiremos os três minutos passarem, não estaremos preocupados com ele, mas mergulhados em um outro tempo. Esse outro tempo é "mais descontínuo", pois está quase que abstraído da instância da enunciação, que nos fincaria no momento presente.

Um teste muito parecido com esse foi aplicado pelo Prof. Lino de Macedo em sua palestra "Piaget, Einstein e a noção de tempo na criança" (2008).

O tempo descontínuo sentido na segunda etapa do nosso teste é associado por Macedo (2008) ao "tempo do jogo", pois quando estamos jogando uma partida de xadrez, por exemplo, quando estamos realmente concentrados nela, sem estarmos pensando Será que o almoço estará pronto assim que essa partida acabar?, ou seja, quando apenas estamos numa situação onde é preciso mexer uma peça, tomar uma decisão, fazer alguma coisa, disse Macedo (2008) que é nesse tempo ocupado, denso, pleno e descontínuo, não mais refém de um passado e de um futuro, que o jogador está vivendo.

Consideramos que o tempo experimentado na primeira etapa, o tempo contínuo, seja uma aproximação do que seria o tempo subjetivo do homem, e que o tempo sentido de forma 
mais descontínua na segunda etapa seja uma aproximação do tempo do mundo real, o tempo objetivo, em que não usamos nossa inteligibilidade sobre ele.

Vivenciamos a experiência de tempo descontínuo, à semelhança da segunda etapa, quando temos uma relação de ocupação mágica com o tempo, e Lino Macedo ainda afirmou que essa ocupação mágica acontece não só no jogo, mas quando se brinca, quando se pinta um quadro, quando se faz uso de uma droga, etc., ou seja, quando não se consegue mais pensar nem em passado nem em presente, nem em futuro.

Temos, por um lado, a abstração do presente, uma vez que "Abstrair o aqui-e-agora significa habitar em pensamento o que não é: interiorizar-se" (GIANNETTI, 2005, p.83), criando, por meio de uma distenção da alma (distentio animi), um universo de interioridade subjetiva. E temos, por outro lado, a quebra (colapso) dessa sensação de descontinuidade, quando nos fincamos em um aqui-e-agora:

A realidade e a força de nossa capacidade de abstrair o presente podem ser claramente evidenciadas pelo seu colapso. Sensações intensas de dor e de prazer, como é fácil notar, absolutizam o momento e obliteram a percepção de passado e futuro: a tirania do aqui-e-agora volta a reinar soberana. A vivacidade da sensação suga e seqüestra o foco de nossa atenção consciente, eliminando qualquer vestígio de perspectiva na percepção temporal. A voragem do êxtase e a irritação da dor restauram no animal humano o desejo uno e o primado de um presente quase absoluto. "Uma pequena ardência sentida", afirma Locke, "nos impulsiona com mais forma do que grandes prazeres prospectivos nos atraem ou cativam.”. (GIANNETTI, 2005, p.83$84)$.

A subjetivação requer abstração do momento presente (mundo das sensações vs mundo da linguagem), pois “[...] quanto mais próximo um ser humano está da [sua] natureza, menos passado e futuro figuram em sua mente [...]" (VALÉRY, 1932, p.97 apud GIANNETTI, 2005, p.88).

Com essas considerações, podemos entender que o ato da enunciação é sempre uma abstração do presente (distentio animi de Santo Agostinho). Mas, dependendo do que se enuncia e com qual intenção enunciamos, essa abstração de um tempo presente pode ser entendida com mais ou menos desprendimento de um aqui-e-agora. Quando enunciamos um discurso $^{15}$ mais desprendido de um aqui-e-agora, podemos entender que ele se torna um "simulacro" do tempo físico descontinuo, e quando enunciamos um discurso menos desprendido de um aqui-e-agora, ele pode se tornar um "simulacro" do tempo físico contínuo.

\footnotetext{
${ }^{15}$ Tratamos discurso como equivalente a texto, ou seja, não estamos considerando as questões de Análise do Discurso, que considera o discurso um termo maior que texto. Dentro dessa unidade do sentido - o texto -, analisaremos o(s) enunciado(s) que a forma.
} 
Em outras palavras, a sensação mágica do tempo pode ser assemelhada, na forma de simulacro, à nossa sensação de quando estamos diante de discursos construídos com tempos narrativos. Um discurso narrativo pode ser uma obra que tem o poder mágico de não chamar a atenção para o real, porque nos fala sobre um mundo narrado, caracterizado por uma distensão ${ }^{16}$ (Weinrich); isso resultaria em um momento de entrega, abandono e plenitude na correnteza do tempo, um momento em que perdemos a "noção da hora". Por outro lado, sobre o tempo contínuo, há situações discursivas em que utilizamos a linguagem para falar de um mundo comentado (Weinrich), caracterizado por uma tensão, como quando os romancistas, principalmente os modernos, por exemplo, nos interrompem do momento mágico de imersão no tempo do narrado, para simular uma conversa com o leitor, nos interrogando e nos "fincando" num outro tempo: naquele tempo em que acabamos por nos lembrar a que horas começamos a ler o livro, onde estamos e o que vamos fazer depois de findar o capítulo. Não podemos deixar de acentuar aqui que essa comparação entre mundo narrado e tempo ontológico é apenas simulacro, pois não poderíamos raciocinar sobre os fatos narrados sem operarmos linguisticamente sobre eles.

Se, como dissemos, o tempo objetivo não necessita de inteligência para ser experimentado, ocorre-nos que, para a criança, antes de seu processo de aquisição de linguagem, a experiência do tempo deveria apresentar algumas pistas sobre essa noção do que seja o tempo ontológico.

Com uma investigação nos estudos de Jean Piaget (1969, 1973, 1975), feitos sobre a noção de tempo na criança ${ }^{17}$, descobrimos que a construção da ideia de tempo na criança não é dada logo quando ela nasce, mas é apreendida ao longo dos seus dois anos de idade.

Isso nos faz pensar que a criança até os seus dois anos de idade está imersa apenas em um tempo objetivo (tempo do mundo) porque ela não tem as noções de tempo contínuo, ou seja, de um tempo cuja linearidade comporta uma sequência de passado, presente e futuro. Ela apenas perceberia o tempo objetivo, caracterizado como uma ordem linear em que os eventos passam de um futuro para um passado.

O fato de que até os dois anos a criança vive num tempo objetivo, somado ao fato de que, depois dos dois anos de idade, a criança passa a ter o tempo dos adultos (o tempo

\footnotetext{
${ }^{16}$ Esse termo "distensão" não está - e não poderia estar - sendo empregado no mesmo sentido que empregou Santo Agostinho em sua distentio animi.

${ }^{17}$ De acordo com Macedo (2008), Albert Einstein, em 1928, quando presidia cursos de filosofia e psicologia em Davos, na Suíça, propôs uma questão "Como os conceitos de tempo, distância e velocidade desenvolvem-se em nível psicológico?" Essa questão inspirou estudos de Piaget sobre as crianças, e 15 anos depois, virou uma das obras mais conhecidas de Piaget, A noção de tempo na criança, em que o pesquisador explora os significados do tempo e como as crianças os compreendem.
} 
subjetivo), nos fez pensar que o estudo da formação da noção do tempo na criança poderia ser uma importante chave de investigação para o nosso modelo descritivo do tempo.

Em um primeiro momento, o que podemos entender sobre os estudos de Piaget sobre o tempo é que quando éramos crianças, não sabíamos muito bem como raciocinar de forma a coordenar os acontecimentos simultâneos ou sucessivos que aconteciam à nossa volta. Isso significa que o modo como concebemos o tempo hoje - um tempo com passado, presente e futuro - é um modo particular de concepção do homem, depois dos seus dois anos de idade. O tempo constrói-se pouco a pouco e é de forma paralela à construção da noção de espaço, de objeto e de causalidade. Segundo Piaget (1975), primeiramente, a consciência da criança é um egocentrismo inconsciente; o $e u$ inconsciente, à medida que se constrói como uma realidade subjetiva, faz com que o mundo exterior vá-se objetivando. O bebê só constrói o mundo objetivo e elabora o seu raciocínio lógico quando passa a ter, com o tempo, a capacidade de considerar a realidade externa e os objetos ao seu redor como diferentes de si mesmo e de um ponto de vista diferente do seu. Enquanto a criança reduz de forma gradual o egocentrismo, ela conquista uma socialização progressiva do pensamento, pois somente com essa descentralização das noções, a criança pode chegar ao estágio da lógica operacional.

Pudemos entender, das afirmações de Piaget, que o bebê sabe ordenar suas ações no tempo - como, por exemplo, sabe abrir a boca antes de introduzir o dedo entre os lábios para depois chupá-lo -, mas isso não significa que ele tenha uma consciência da ordenação das ações, ou seja, não significa que ele pensa sobre o que faz porque ele ainda não tem linguagem.

Existe uma inteligência antes da linguagem, mas não existe pensamento antes da linguagem. Distingamos a esse respeito a inteligência e o pensamento. A inteligência é a solução de um problema novo para o indivíduo, é a coordenação dos meios para atingir um certo fim, que não é acessível de uma maneira imediata, enquanto o pensamento, é a inteligência interiorizada e se apoiando não mais sobre a ação direta, mas sobre um simbolismo, sobre a evocação simbólica pela linguagem, pelas imagens mentais, etc. que permitem representar o que a inteligência sensório-motora, pelo contrário, vai apreender diretamente. (PIAGET, 1973, p.15-16).

Seria, então, apenas com aquele tempo descontínuo de que tratamos (tempo objetivo) que "operaria" a criança até os seus dois anos de idade, porque ela ainda não tem uma linguagem que possa atuar sobre esse tempo descontínuo, fazendo com que ele sirva de apoio para um tempo operativo - o nosso tempo subjetivo. Depois dos dois anos de idade, ela tem adquirido o tempo operacional, que é o tempo que nós adultos utilizamos no nosso dia a dia. $\mathrm{O}$ tempo é adquirido porque ela adquire a língua; e porque a língua possui o tempo nessa 
configuração, a criança aprende o tempo assim. Esse tempo operacional é o tempo contínuo em que sentimos noções de passado, presente e futuro; é o tempo sentido na primeira etapa do nosso teste. A criança, uma vez adquirido o tempo operacional, só sairá dele e só voltará ao tempo descontínuo quando, por exemplo, pintar um quadro, ouvir uma música relaxante, fazer uso de uma droga ${ }^{18}$, ou qualquer coisa que a faça não saber que "o relógio da vida" está funcionando. Essas experiências, a do jogo, a da arte, a do relaxamento, a da droga, provavelmente sejam apenas aproximações do que seja realmente esse "tempo inicial nãoconstruído" da criança. Mas, sem dúvida, essas experiências mostram o quanto o tempo pode ser experimentado e sentido de duas formas distintas.

Podemos entender dessas coisas que tudo para a criança até os dois anos de idade nasceria e renasceria a cada momento. O futuro, ou a experiência nova, vem até ela e lhe traz algo novo, mas como ela não tem linguagem e não tem memória ela não conseguiria carregar consigo essas experiências passadas.

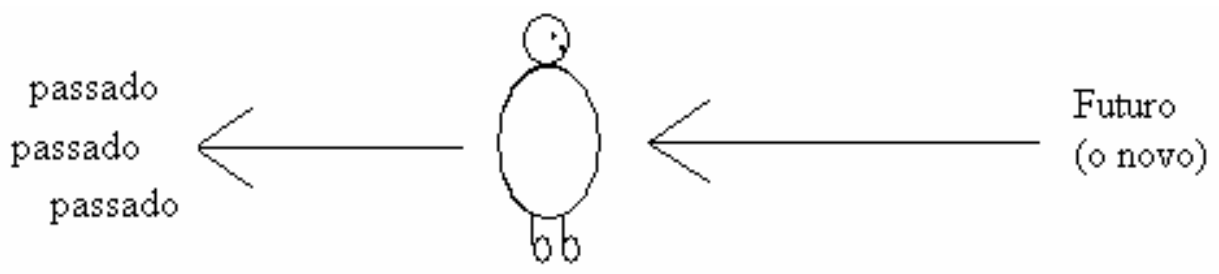

Figura 9 - A passagem do tempo através da criança

Nessa ilustração 9, as experiências passadas não permanecem com a criança, mas se afastam para trás dela. É claro que a criança tem uma historicidade e uma memória antes de adquirir a língua, porque ela existe, e tudo que tem existência tem uma história; ninguém mama por ela, ela é a protagonista dessa atuação. Mas do ponto de vista dela, ela ainda não tem sua própria narratividade.

Sendo assim, se a uma criança que ainda não tem o tempo operativo, fosse perguntado quem nasceu primeiro? você ou sua mãe?, a criança não saberia responder, porque ainda não faz relações temporais. Uma outra criança poderá responder que ela nasceu primeiro que a mãe, porque ela se coloca sempre como ponto de partida nas suas relações.

\footnotetext{
Antes de nós vieram as crianças. Quem nasceu antes? As crianças nasceram antes e portanto são mais velhas do que nós, se se pensa como referência o ponto de partida. Agora, se a gente pensa como ponto de chegada, ou se a gente pensa a referência adulta, de fato somos mais velhos do que as crianças. Nós morremos, as crianças são eternas, nesse sentido de que sempre algo recomeça com uma criança. (MACEDO, 2008, p.3)
}

\footnotetext{
${ }^{18}$ Não estamos querendo fazer apologia ao uso das drogas.
} 
Se considerarmos que a criança vive sobre uma linha do tempo direcionada da direita para a esquerda, porque se direcionaria do futuro para o passado, à semelhança do que vimos na figura 6,7 e 8 , teremos a relação antes/depois, do ponto de vista da criança, da seguinte forma: é antes o que está indo contra a direção do tempo (para o futuro) e depois o que segue a direção do tempo (para o passado).

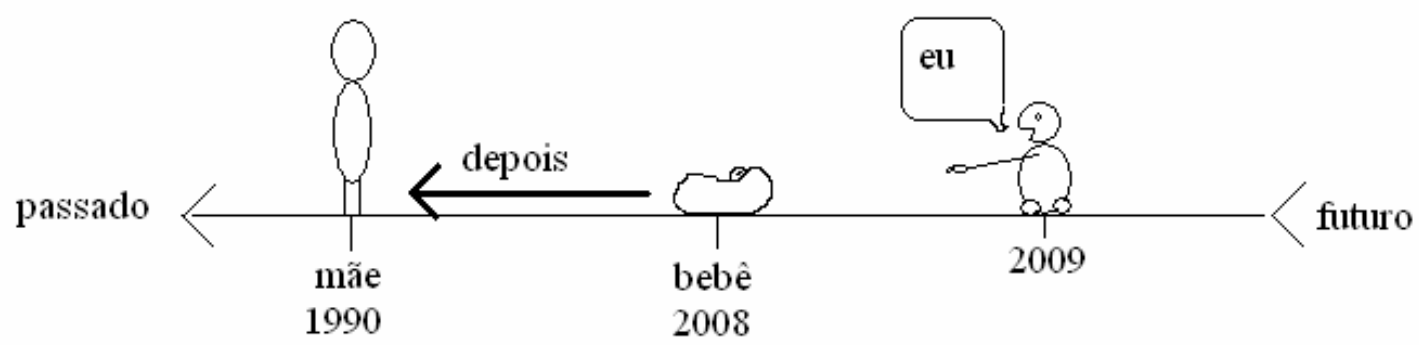

Figura 10 - Interpretação temporal da criança sobre a linha do tempo

Nessa figura 10, a criança entenderia que sua mãe nasceu depois dela porque ela faz a relação antes/depois partindo do seu ponto sobre a linha do tempo; a inteligência da criança nesse momento estaria apoiada sobre a ação direta.

Decorrido alguns meses, tendo a criança já apreendido o tempo operacional, se lhe perguntassem quem nasceu primeiro, a resposta seria diferente:

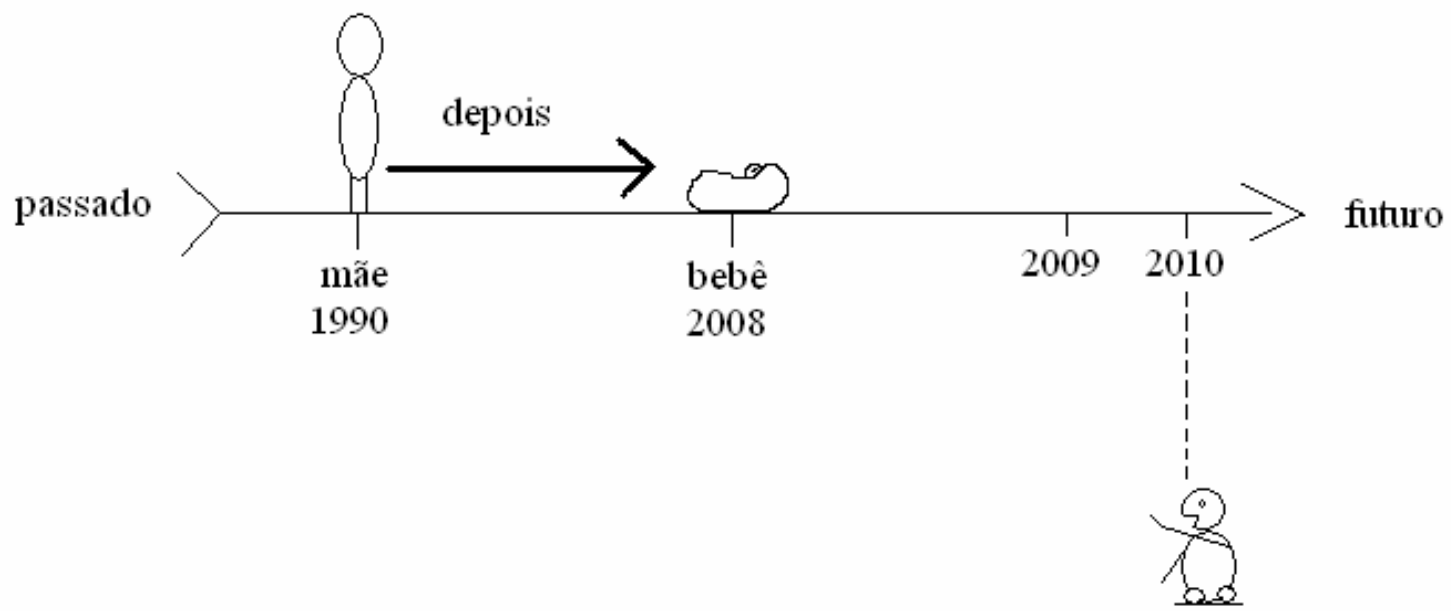

Figura 11 - Interpretação temporal da criança fora da linha do tempo

Nessa outra figura 11, a criança não estaria mais num ponto sobre o tempo, mas estaria vendo o tempo "de fora", de forma operatória. Por isso, ela poderia estabelecer uma relação 
de anterioridade e posterioridade, a partir da direção convencionada por nós como do passado para o futuro. Esta relação que a criança adquire com o tempo acontece quando

[...] o tempo é promovido à categoria de estrutura objetiva do universo como tal: a sucessão consumada, na série de acontecimentos recordados, constituindo a história do meio ambiente, em vez dessa história permanecer incoerente e fragmentada, como anteriormente, e seus fragmentos continuarem agarrados à ação presente, concebida esta como realidade única.

Vê-se que, a partir da inteligência sensório-motora, o tempo supera necessariamente a "duração pura" e que, embora essa duração esteja nas origens do tempo, jamais se tornaria sem uma espacialização e uma objetivação inseparáveis de toda a atividade intelectual [...] (PIAGET, 1975, p.299-300).

Quando nessa passagem Piaget explica que a "duração pura” está na origem do tempo, ele está dizendo, a nosso ver, que o tempo original (entendido nos termos que estamos utilizando como o tempo objetivo) é aquele mesmo tempo entendido como o único que a criança entende antes de aprender a linguagem. ${ }^{19}$

Entretanto, particularmente não acreditamos que a criança participe até os dois anos de idade de um mundo sem memória. A memória é uma atividade cognitiva extremamente importante, pois ela forma a base para a aprendizagem. Se a figura 9 fosse verdadeira, a criança nunca aprenderia a linguagem, porque ela nunca teria lembranças. Não é possível aprender uma língua sem uma memória, e talvez isso aconteça antes do que afirma Piaget. De qualquer forma, os estudos sobre o tempo na criança, como pudemos ver, também distinguem dois tempos, confirmando a forma resumida com que tratamos a intratemporalidade heideggeriana ou o tempo do mundo sensível de Platão. Isto porque Piaget diz que há o tempo da "duração pura" (nosso tempo objetivo) e o tempo operacional que é quando a linguagem inteligibiliza o tempo do mundo (nosso tempo subjetivo).

A aquisição da noção de tempo na criança é muito complexa e necessitaria de um estudo voltado apenas a ela. No entanto, pensamos em discutir alguns conceitos para ilustrar alguns limites possíveis do nosso objeto de estudo.

Como vimos, o tempo objetivo pode ser entendido como uma seta que vai do futuro ao passado, e o tempo da nossa atividade intelectual (o tempo operacional, subjetivo) pode ser entendido como uma seta que vai do passado para o futuro. Este tempo pode ser inserido dentro daquele, ou seja, o tempo subjetivo está dentro do tempo objetivo, uma vez que nós somos seres inseridos no mundo. Essa inserção será representada, a seguir (figura 12), por um

\footnotetext{
${ }^{19}$ Piaget considera o tempo como algo do mundo, ou seja, como uma propriedade objetiva, empírica das coisas, completamente independente da natureza de quem conhece.
} 
vértice de um ângulo agudo que projeta, por duas retas, uma extensão do ponto (instante) que é tocado na linha do tempo objetivo. Em outras palavras, a linha do tempo objetivo representa o mundo, o vértice representa um ser humano inserido nesse mundo e a projeção representa o que ocorre em seu cérebro - a linha do tempo subjetivo. Finalmente, podemos chegar a um modelo geral do tempo concebido pelo homem sugerido por essa Dissertação:

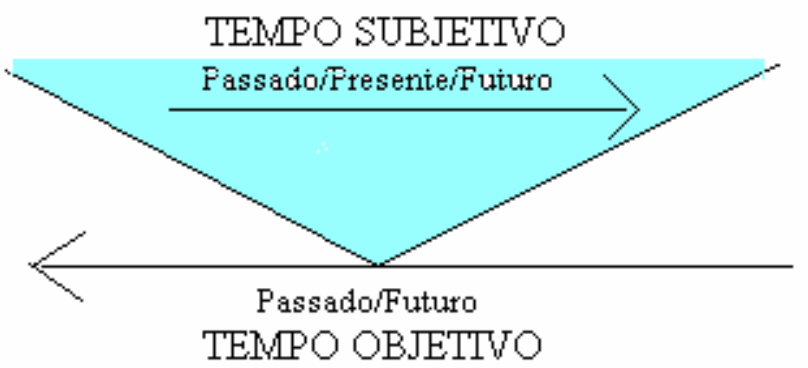

Figura 12 - Esquema geral do tempo físico e psicológico

Este esquema (figura 12), portanto, é um esquema geral do tempo do mundo concebível pela psique humana e se assemelha ao mesmo esquema usado para descrever a distentio animi de Santo Agostinho, na figura 2 e 3. Como vimos, Pavlov provou que não só os seres dotados de inteligência, mas também os animais possuem um reflexo da seta do tempo objetivo do mundo (futuro ao passado) na nossa psique. Entretanto, como vimos em Piaget $(1969,1973,1975)$ e Hawking, é porque somos seres dotados de inteligência e memória que possuímos uma outra seta do tempo: a seta subjetiva do tempo e, como nosso cérebro funcionaria de forma a temporalmente se mover do passado para o futuro, a nossa psique (somente a dos seres humanos) também possui um reflexo dessa seta do tempo subjetivo.

Assim como o homem se insere no mundo real, o tempo subjetivo se insere no tempo objetivo, e, com isso, não podemos esquecer que o tempo subjetivo é também objetivo, tanto porque o tempo subjetivo perpassa pelo objetivo, quanto porque o tempo objetivo promove o sentido ao tempo subjetivo, por ser sua referência.

O modelo geral do tempo descrito na figura 12 está sendo entendido como uma descrição de um tempo concebível pelo homem, isto porque a referência ao mundo é uma "semântica linguística". Sabemos que não estamos fazendo referência ao mundo físico, mas ao mundo de sentido construído pelo homem. Estudamos o modo como concebemos o tempo, e não como ele deve ser. 
A linguagem - a fala humana - é uma inesgotável riqueza de múltiplos valores. A linguagem é inseparável do homem e segue-o em todos os seus atos. A linguagem é o instrumento graças ao qual o homem modela o seu pensamento, seus sentimentos, suas emoções, seus esforços, sua vontade e seus atos, o instrumento graças ao qual ele influencia e é influenciado, a base última e mais profunda da sociedade humana. (HJELMSLEV, 1975, p.1)

Por isso, descrever o tempo como na figura 12 é descrever o modo como nós construímos a ideia de tempo, mesmo que se tente criar uma descrição objetiva.

\section{4 - A referência semântica do tempo}

Um texto sempre apresentará algum elemento temporal. Se quisermos buscar no mundo real uma referência para o tempo que aparece nesse texto, encontraremos apenas o instante, porque o instante é o único tempo real que pode ser referenciado. Por outro lado, a significação é a relação recíproca e reversível entre o nome e o sentido que o falante dá as coisas (Ullmann, 1977), e, portanto, nossa pergunta deveria ser outra: qual é o sentido que damos ao tempo?

Como os semanticistas possuem diferentes visões a respeito do que seja o significado e a significação, há várias teorias semânticas: textual, cognitiva, lexical, argumentativa, discursiva, etc. Cada uma estuda o significado a sua maneira e "[...] todas elas vão encontrar limites em seu alcance. Nenhuma teoria científica escapa a essa limitação, na medida em que todas elas precisam, necessariamente, recortar seu objeto de estudo." (MÜLLER; VIOTTI, 2003, p.138).

Pela enunciação, empregamos a noção de tempo cujo sentido será dado dependendo de cada enunciação enunciada. A referenciação semiótica - e não mais uma referenciação do mundo - descreve os vários tempos criados pelo discurso.

Os estudos do discurso literário se preocupam muitas vezes em definir a referência do tempo pela ausência de referente ou pela correspondência com um referente fictício ou imaginário. Por outro lado, a impossibilidade de também definir o referente "real" de um discurso oral, por exemplo, faz este tipo se igualar ao tipo de texto de ficção e, portanto, eles não podem ser caracterizados a não ser por critérios de verdade, mas critérios analisados no

próprio referente interno que esses discursos criam: o mundo possível. Portanto, a referenciação semiótica do tempo só pode ser feita sobre os espaços mentais criados pelo 
texto, mesmo que esse discurso fale de um mundo real. Estes espaços mentais são construídos pela linguagem por meio das coordenadas enunciativas de pessoa, espaço e tempo. Entretanto, essa linguagem em forma de texto, quando estudada pelo linguista, deve, além da referência semiótica da enunciação enunciada, entender também o momento em que o texto foi escrito, por meio de uma semântica formal, ou seja, a referenciação semiótica depende de uma referenciação semântica ao mundo real.

Benveniste utiliza o tempo semiótico em oposição a semântico, para traçar uma divisão entre dois domínios da língua. O campo do semiótico corresponde à língua na acepção saussureana, sendo o signo sua unidade. Embora esse linguista assim delimite o sistema semiótico, este não é independente do semântico, e vice-versa, pois ambos se superpõem, constituindo a língua tal como é utilizada. (FLORES, et alli, 2009, p.206).

Isto porque devemos entender que, enquanto um determinado tempo é falado por meio de um texto, um texto é falado por meio de um tempo, e este ultimo é o tempo real de produção-recepção; embora o tempo real seja apenas um instante, esse instante não é único, ele percorre o tempo, uma vez que o tempo é uma das dimensões que permite criar um mundo possível. "O que pertence ao tempo, como as palavras de um texto, obedece à lei da sucessão: uma após a outra, a concomitância produziria apenas um absurdo e impenetrável borrão." (GIANNETTI, 2005, p.68).

Essa mesma dimensão do tempo impõe condições à referência ao texto, fazendo com que uma análise da enunciação enunciada não seja suficiente na descrição total do tempo linguístico. É preciso também uma referência lógica ao mundo, e extralinguística.

Uma semântica formal concentra-se no estudo da relação que existe entre as expressões linguísticas e o mundo.

[...] na Semântica Formal, o significado é entendido como uma relação entre a linguagem por um lado, e, por outro, aquilo sobre o qual a linguagem fala. Esse 'mundo' sobre o qual falamos quando usamos a linguagem pode ser tomado como o mundo real, parte dele ou mesmo outros mundos ficcionais ou hipotéticos.

Conhecer o significado de uma sentença, dentro desse paradigma, é, em parte, conhecer suas condições de verdade. Conhecer as condições de verdade de uma sentença significa saber em que circunstâncias, no mundo, aquela sentença pode ser considerada verdadeira ou falsa. (MÜLLER; VIOTTI, 2003, p.139).

É por isso que compreendemos o enunciado (3) Quebrou, pagou! quando empregado em sentido contextual igual a (4) Se você quebrar, você terá que pagar!. Porque saberemos, dentro de um contexto real, que ninguém quebrou nada, e ninguém pagou nada. 
Por que consideramos que é importante conhecer a Semântica Formal? Por vários motivos. Primeiramente, porque só ela se propõe analisar algumas questões relacionadas ao significado das línguas naturais. Segundo, porque ela é, explícita ou implicitamente, em maior ou menor grau, utilizada nas análises de outras semânticas, como a Semântica Cognitiva e a Semântica Argumentativa, e também na Pragmática e na Sintaxe, tanto a funcional quanto a gerativa. (MÜLLER; VIOTTI, 2003, p.156)

Uma semântica formal se preocupa com uma semântica referencial, com o cálculo semântico adequado entre a linguagem e os critérios de verdade baseados num mundo real.

Quando o homem opera a linguagem, ele cria um mundo possível. Seja qual for a tipologia do discurso. Este, por sua vez, pode falar de um mundo real ou imaginário. Nesses dois casos, os termos linguísticos farão referência à situação comunicativa descrita pela linguagem, mas a interpretação total do discurso, como veremos, necessitará da intenção da pessoa que enunciou e do seu espaço-tempo.

Mateus (1983) afirma que a significação deve levar em conta dados da realidade e objetivos comunicativos para um tratamento de aspectos semânticos no plano da competência comunicativa dos falantes. Um desses fatores, dentre os seis que Mateus destaca, é "Estruturar, nomeando e pondo em relação, objetos e propriedades do mundo real; essas relações se estabelecem quer por apreensão direta dos fatos, quer por atividades classificatórias e mentais que envolvem mecanismos cognitivos abstratos e complexos" (MATEUS, 1983, p.41 apud MARQUES, 1995, p.56).

O contexto que se depreende de um discurso, quando se refere ao tempo, algumas vezes necessita claramente de um contexto real de produção-recepção. O texto ou discurso precisa ser tratado no seu contexto pragmático $^{20}$ do mundo real, ou seja, conjunto de condições externas ao texto - produção, recepção e interpretação; o uso da pragmática fornece uma melhor base linguística para a elaboração de modelos cognitivos de desenvolvimento, produção e compreensão da linguagem.

A identificação da referência de um verbo envolve, dentro da nossa competência linguística, um conhecimento lexical, sintático, semântico e pragmático. Saber o significado da sentença é saber que tipo de mundo ela pretende descrever. Precisamos saber o que permite que construamos as condições de verdade de um enunciado a partir do significado de suas partes, para podermos ser capazes de explicar onde um evento se situa em um tempo recriado pela linguagem, e quais são as grandes formas de tempo recriadas.

\footnotetext{
${ }^{20}$ Estamos nos referindo a uma pragmática norte-americana.
} 
Quanto ao tempo gramatical, é significativo o fato de que ninguém conseguiu ainda descrever satisfatoriamente o significado dos tempos gramaticais (identificados tradicionalmente por termos como 'passado', 'presente', 'futuro') em inglês nem em qualquer língua bastante estudada. E o tempo é, de todas as categorias gramaticais, a que parece, a primeira vista, a mais facilmente definível do ponto de vista semântico. (LYONS, 1987, p.153). 


\section{Capítulo 3 - O TEMPO DA LINGUAGEM}

\section{1 - NÍVEL A) O tempo real da linguagem}

Um homem que dorme, mantém em círculo em torno de si o fio das horas, a ordem dos anos e dos mundos. Ao acordar consulta-os instintivamente e neles verifica num segundo o ponto da terra em que se acha, o tempo que decorreu até despertar; (PROUST, 1979, p.8)

O que o tempo lingüístico tem de singular é o fato de estar organicamente ligado ao exercício da fala, o fato de se definir e de se organizar como função do discurso.

(BENVENISTE, 2006, p.74)

Depois da revisão de literatura sobre o tempo na Física, na Filosofia e em Piaget (1969, 1973, 1975), pudemos chegar a duas importantes concepções de tempo: a subjetiva “passado-presente-futuro" e a objetiva "futuro-passado". Como vimos na figura 12, o modelo ilustra a localização do homem no tempo do mundo, uma vez que o tempo subjetivo pertence à concepção operacional humana sobre o tempo, e o homem está inserido dentro do tempo do mundo (tempo objetivo).

Neste capítulo 3, tratamos da linguagem humana e, para continuarmos nossas ilustrações do tempo, precisamos fazer uma "ponte" capaz de ligar o tempo do mundo ao tempo da linguagem: essa ponte será a enunciação (Benveniste, 2006), pois, se há um tempo linguístico a ser analisado, é porque alguém mobilizou a linguagem, ou seja, enunciou.

A linguagem humana, por ser uma atividade temporal por natureza, e por depender da capacidade intelectual humana, pode ser representada pela linha do tempo subjetivo do nosso modelo geral do tempo:

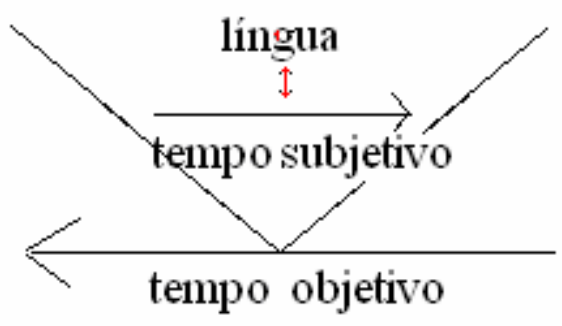

Figura 13 - Localização do tempo da linguagem 
$\mathrm{O}$ ato da linguagem, assim como todos os atos, ocorre de forma a crescer com a medida do tempo, se dirigindo, nesse sentido crescente, do passado para o futuro. Por outro ponto de vista, não podemos esquecer que a linguagem, sendo um ato, "passa" com o tempo, ou seja, se move pela linha do tempo objetivo, se movimentando do futuro para o passado, porque, como dissemos, o tempo subjetivo está inserido no tempo objetivo.

O tempo da linguagem pode corresponder ao tempo subjetivo no nosso modelo pelo argumento de que a língua é um ato que só tem sentido quando operada subjetivamente. A compreensão discursiva também é um ato; compreender temporalmente um discurso representa uma linearidade construída no tempo.

Tendo sido identificado, no esquema geral do tempo do mundo, qual o local do tempo linguístico (figura 13), iremos discutir algumas outras teorias sobre como pode ser descrito o tempo linguístico. Veremos que um modelo básico do tempo linguístico torna-se muito parecido com o modelo do tempo geral (figura 12), como se fosse um simulacro dele. Isso acontece porque o tempo da linguagem parece comportar duas setas de sentidos distintos.

A conhecida afirmação de que uma narrativa é um simulacro de ações do mundo pode, em relação ao tempo, ser entendida da seguinte forma: o tempo das ações do mundo é verdadeiro e real; os indivíduos no planeta Terra ${ }^{21}$ agem sobre uma mesma linha temporal. Mas quando a ação de que falamos é a ação da narrativa (discurso), essa ação gera um tempo que é um simulacro do tempo verdadeiro, assim como essas ações linguísticas descritas com palavras são simulacros de ações do mundo.

Por isso, o tempo das ações linguísticas (tempo do discurso) não tem a ver com o tempo verdadeiro. De acordo com a natureza real da linguagem, “[...] o único tempo inerente à língua é o presente axial do discurso, e [...] este presente é implícito.” (BENVENISTE, 2006, 76). Neste momento, Benveniste não se refere a um tempo do discurso, mas a um tempo determinado pelo presente axial. Este determina duas outras referências temporais;

[...] estas são necessariamente explicitadas em um significante e em retorno fazem aparecer o presente como uma linha de separação entre o que não é mais presente e o que vai sê-lo. Estas duas referências não se relacionam ao tempo, mas as visões sobre o tempo, projetadas para trás e para frente a partir do ponto presente. Esta parece ser a experiência fundamental do tempo, de que todas as línguas dão testemunho à sua maneira. Ela informa os sistemas temporais concretos e notadamente a organização formal dos diferentes sistemas verbais. (BENVENISTE, 2006, p.76).

\footnotetext{
${ }^{21}$ O sistema de referência da linguagem do dia a dia é a Terra: sua gravidade, sua velocidade, sua distância em anos luz dos astros, etc.
} 
Essas temporalidades são da ordem da linguagem e não do discurso. Cada uma delas reflete uma atitude ou visão do falante, que chamaremos de mundo comentado e mundo narrado, inspirados na distinção feita por Harold Weinrich (1968), quando dividiu as formas plenas do modo indicativo em dois grandes grupos: récit e commentaire. Weinrich se inspirou na distinção de Benveniste quando este afirma que o discurso pode apresentar dois tipos de tempo, afirmando que o presente axial "determina duas outras referências temporais" (BENVENISTE, 2006, 74): o tempo da história e o tempo do discurso.

Com a figura 14 a seguir, ilustramos uma linha do tempo projetada pelo falante por meio da linguagem. A partir do seu momento presente real, o falante pode se projetar atrás ou à frente no tempo em que se encontra, para dentro de algum outro mundo, de onde os eventos aparecerão para ele como sendo do passado (mundo narrado) ou do futuro (mundo comentado).

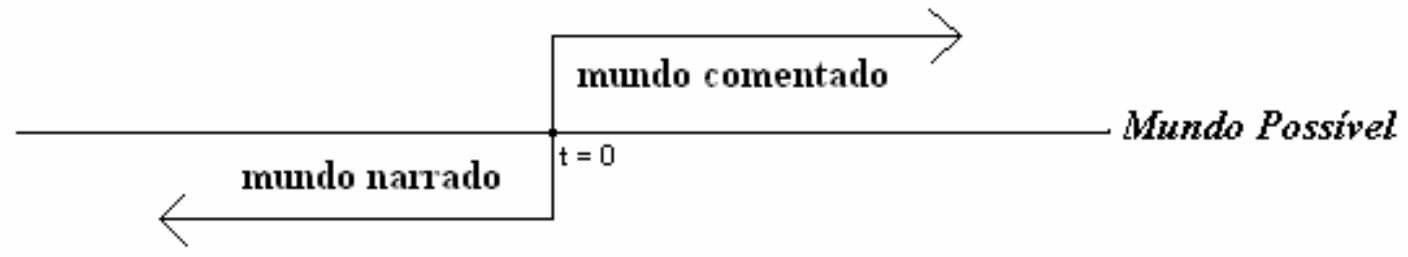

Figura 14 - Mundo narrado e mundo comentado localizados a partir de um ponto temporal zero

Com essa ilustração, perceberemos a relação entre os dois sistemas e o tempo zero:

Enquanto a narração, como comportamento característico do homem, é mais descompromissada, pois o passado já foi transformado e talvez nada informe sobre a veracidade ou ficção do relato, a atitude comunicativa comentada é mais tensa. Nela o falante está comprometido com o seu discurso, porque fala sobre coisas que não só o afetam como também ao ouvinte [...]. (SILVA, 2002, p.33).

Pretendemos demonstrar que os dois grandes mundos possíveis podem ser esquematizados com duas setas do tempo de movimentações contrárias: uma do futuro ao passado (à semelhança do tempo objetivo), ilustrando o mundo narrado; outra do passado ao futuro (à semelhança do tempo subjetivo), ilustrando o mundo comentado. 


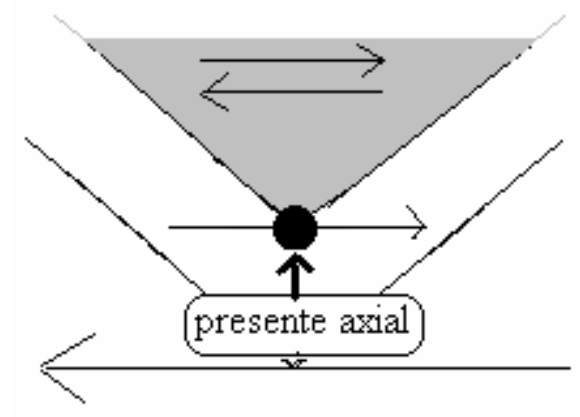

Figura 15 - O presente axial da linguagem e a sua projeção para o mundo possível

Entendemos que o presente axial divide-se em dois sistemas: o plano do discurso e o plano da narração. Esses dois planos são determinados por um momento zero da enunciação chamado de presente axial do discurso. Este é sempre presente, e é o único tempo real empregado no discurso, pois, como vimos, "A língua deve, por necessidade, ordenar o tempo a partir de um eixo, e este é sempre e somente a instância do discurso." (BENVENISTE, 2006, p.75). Este presente axial determinará momentos da fala que serão as referências ao texto; são pontos zeros, assim como o momento do ato de enunciar, mas os momentos da fala não são mais entendidos como ligados ao tempo real da linguagem, pois são da ordem do discurso, ou seja, de um tempo possível dentro de um mundo possível criado pela linguagem.

Com essas afirmações, podemos defender na nossa ilustração (figura 15) que o tempo criado pela linguagem, gerado pelo presente axial, está "desancorado" do tempo subjetivo; assim é que podemos falar de um futuro hoje que será passado amanhã, pois o tempo do mundo possível (criado pela linguagem) não depende do mundo real. Por isso, o amanhã de hoje será o hoje de amanhã. A falta de uma ancoragem, no entanto, é apenas semântica, pois de um ponto de vista discursivo, o presente axial é quem comanda a inteligibilidade do tempo que a linguagem cria, ou seja, o tempo do discurso, através de um presente axial do discurso que é sempre pressuposto. Portanto, o presente axial tanto faz parte do tempo real quanto faz parte do tempo linguístico, porque ele é quem gera o discurso. 


\subsection{1 - As duas direções do tempo}

Gustave Guillaume (1968 apud BECHARA, 1984) possui uma teoria fundamentada na ideia de que o tempo verbal - que é um tempo operativo - se instaura por meio de uma temporalidade dupla:

[...] ao mesmo tempo que toma como causa a duração histórica dos fatos, toma também o conteúdo mental de cada instante nos quais essa duração se decompõe. Isto é, essa temporalidade é considerada não só enquanto sucessividade de momentos históricos, mas também como sucessividade de momentos mentais, cuja seqüência ordenada constitui a própria organização do pensamento em operação no tempo, i.e., sua programação. (BECHARA, 1984, f.2).

Ao estudar a questão do tempo na linguagem (localizado dentro do nosso modelo geral no tempo subjetivo - figura 13), Guillaume percebe que há uma dupla série temporal: a de momentos históricos e a de momentos mentais.

O linguista Mauricio Molho (1975), estudioso e seguidor das teorias de Gustave Guillaume, afirma que há dois modos de percepção do tempo descritos como dois cinetismos: o descendente e o ascendente. Esses dois modos de perceber o tempo se articulam da seguinte forma: o cinetismo ascendente é aplicado sobre o cinetismo descendente fundamental, ou seja, depois que se tem em mente a imagem do tempo fundamental, concebe-se outra imagem, um cinetismo essencialmente operativo no qual o pensamento vai poder inscrever sua atividade; o tempo ascendente é ativado pelo sujeito, enquanto o tempo descendente fundamental, concebido pela mente na imediata proximidade da experiência, é objetivo (MOLHO, 1975, p.63).

Bechara (1984), que trabalhou com a teoria de Molho, dentre outras, estudou o modo como se opera o tempo na linguagem na língua portuguesa.

[...] em português, a mente cria dois cinetismos antagônicos e paralelos: cinetismo prospectivo [descendente] e cinetismo retrospectivo [ascendente].

O primeiro representa o "movimento que a mente faz no tempo", do pretérito ao futuro, criando o tempo subjetivo. $\mathrm{O}$ segundo representa o "movimento que o tempo faz na mente" do futuro ao pretérito, criando o tempo objetivo. Neste particular, a análise dos tempos verbais do português guarda certas semelhanças com a dos tempos verbais do espanhol, feita por Mauricio Molho (1975). (BECHARA, 1984, p.50).

Essas movimentações são representadas com "setas" do tempo de orientações, pois a mente vendo-se pensar a ordenação descendente, quando o tempo subjetivo é aplicado sobre o 
tempo objetivo, toma por objeto a mesma ordenação, resultando em "setas" do tempo de orientações contrárias.

Herbert Clark (1973) também possui uma teoria de como interpretamos o tempo, muito semelhante às teorias de Guillaume (1968) e de seu seguidor Molho (1965). Preferimos adotar os seus termos para as duas temporalidades em questão porque sua explicação tem mais poder ilustrativo.

O tempo pode ser visto como uma estrada contendo uma sucessão de eventos distintos. Nós, humanos, somos vistos de duas maneiras em relação à estrada: ou (1) nós nos movemos ao longo da estrada, com o tempo real futuro a nossa frente e o passado atrás de nós; ou (2) a estrada se move passando por nós, de frente para trás. Essas são as duas metáforas que podem se chamar metáforas do ego movente e do tempo movente, respectivamente $^{22}$. (CLARK, 1973, p.50).

Em outras palavras, Clark afirma que o tempo pode ser visto como uma estrada que contém eventos distintos em sucessão. A língua portuguesa possui diversas categorias linguísticas para possibilitar marcações temporais nessa estrada (que é uma metáfora do tempo contínuo da língua), como os advérbios, os numerais, os verbos, frases inteiras, etc. Essas formas são dispostas na linha do tempo de forma crescente, do passado ao futuro, que está representado na figura 16 da esquerda para a direita, uma vez que a língua portuguesa é compreendida numa linearidade que segue a direção da esquerda para a direita. Exemplo:

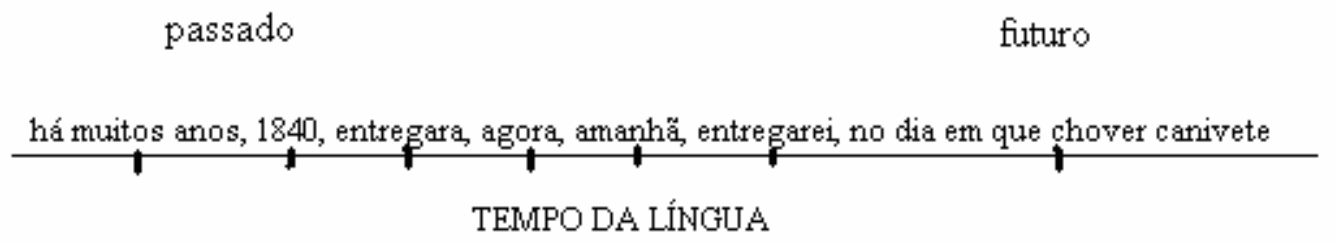

Figura 16 - Linha do tempo crônico

Nesta linha do tempo, os acontecimentos nunca ${ }^{23}$ podem ser dispostos de forma diferente da lógica da causalidade, determinada pela cultura da língua em questão.

\footnotetext{
${ }^{22}$ No original: Time can be viewed as a highway consisting of a sucession of discrete events. We humans are seen in one of two ways with respect to this highway: either (1) we are moving along it, with future time ahead of us and the past behind us; or (2) the highway is moving past us from front to back. These two metaphors might be called the moving ego and moving time metaphors, respectively.

${ }^{23}$ Entretanto, como vimos, não sabemos até onde vão as possibilidades do tempo. Nos estudos mais modernos de Física, principalmente os de Física Quântica, há muitas questões sobre a reversibilidade do tempo, por exemplo.
} 


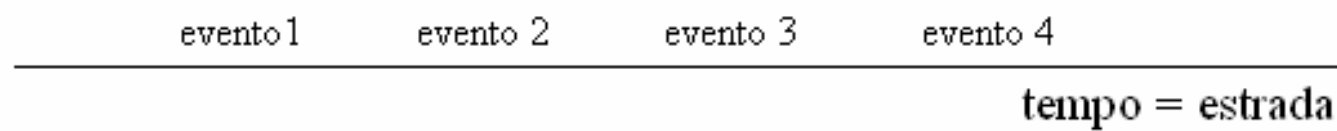

Figura 17 - Metáfora da estrada contendo eventos discretos

Podemos identificar essa metáfora da estrada com o conceito de tempo crônico de Benveniste: "No tempo crônico, o que denominamos 'tempo' é a continuidade em que se dispõem em série estes blocos distintos que são os acontecimentos" (BENVENISTE, 2006, p.71). Este autor defende que o tempo da nossa percepção não pode ser o tempo físico, entendido na sua forma pura, pois concebemos o tempo juntamente com a ordem das mudanças, mas os acontecimentos não são o tempo, apenas estão no tempo. Aliás, "Em nossa visão do mundo, assim como em nossa existência pessoal, não há senão um tempo, que é este.” (BENVENISTE, 2006, p.71).

O tempo, segundo Clark, é concebido ora como uma estrada fixa onde os eventos se dão e o ego se move em direção ao futuro, ora como uma estrada em movimento trazendo do futuro para o passado todos os eventos e "estados de coisas" que passam diante do ego (imóvel) que apenas os observa, voltado com a frente para o futuro, e as costas para o passado. Resumidamente, há dois movimentos: ora somos nós que nos movimentamos pelo tempo (figura 18), ora é o tempo que se movimenta por nós (figura 19).

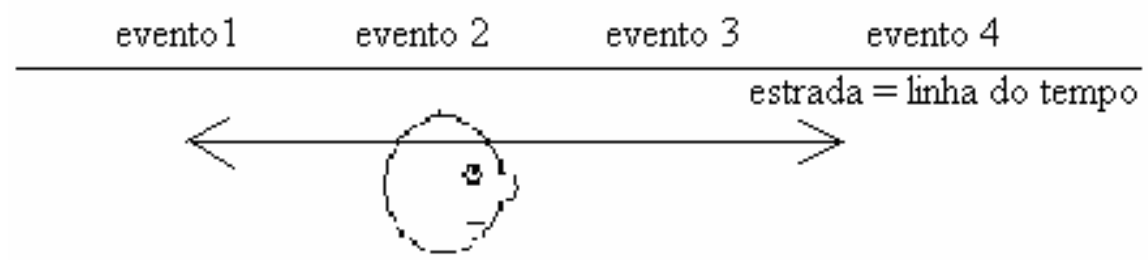

Figura 18 - Metáfora do ego movente

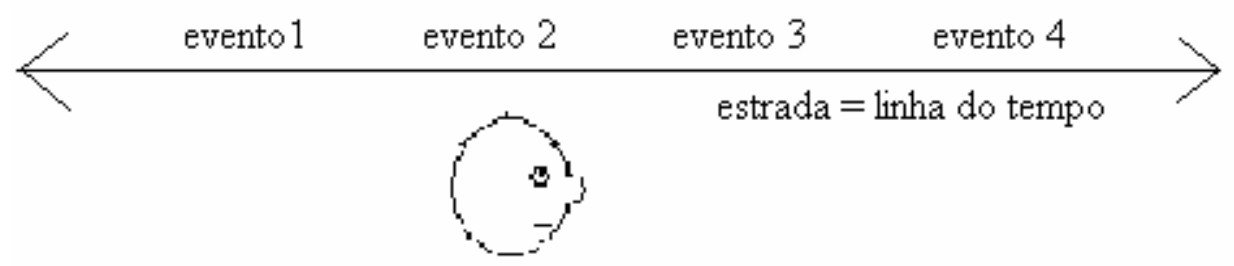

Figura 19 - Metáfora do tempo movente

Dissemos que as metáforas de Clark se assemelham à teoria de Molho. Isto porque, se as duas "palavras-chaves" na compreensão da teoria de Molho "pensamento" e "tempo" forem 
consideradas respectivamente como "ego" e "estrada" (termos da teoria de Clark), poderemos fazer a seguinte correspondência: o cinetismo ascendente, que é o movimento do pensamento no tempo, corresponde ao movimento do ego no tempo, ou na estrada fixa; e o cinetismo descendente que é o "movimento do tempo no pensamento" pode corresponder ao tempo movente, uma vez que o tempo movente de Clark é uma estrada em movimento, pois o tempo passa pelo homem (ego), ou seja, passa pelo pensamento e, portanto, é um movimento do tempo no pensamento.

Clark (1973) apresenta vários exemplos em língua inglesa, mostrando-nos como, de fato, a língua pode apresentar essas duas formas de direcionarmos nossa visão sobre a linha do tempo. Por exemplo, será que devemos dizer que o futuro é o que está vindo ou é o que virá? A diferença para as duas respostas possíveis está no foco dado para o evento. Se se responde que o futuro é o que está vindo, foca-se apenas o evento; se se responde que o futuro é o que virá, o ego é quem vê o tempo.

Ao analisarmos, por exemplo, a frase

(5) A primavera precede o verão.

poderemos entender melhor as duas metáforas de Clark:

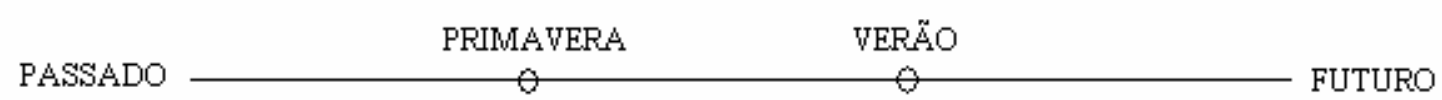

Figura 20 - Disposição do exemplo (5) em uma linha do tempo

Em um primeiro momento, podemos dizer que as duas estações foram dispostas em uma linha do tempo (passado-futuro) de forma que o termo Primavera ficasse "atrás" do termo Verão. Entretanto, se analisarmos o significado do verbo preceder, deveríamos dizer que a Primavera está "na frente do" Verão, pois preceder significa "ir ou vir na frente de".

Essa contradição também aparece com outros termos da língua portuguesa, por exemplo:

- $\quad$ Seguir = ir/vir atrás de;

- Pré- = prefixo: na frente de, em direção ao passado de;

- Pós- = prefixo: atrás de, em direção ao futuro de. 
Essas expressões poderiam ser classificadas como atemporais, porque não se colocam num tempo dêitico da língua, mas num tempo extralinguístico, de orientação lógica (cronológica). Isso mostra, dentre outras coisas, que há uma movimentação não dêitica (não estabelecida pelo ego) na linha do tempo. Esse pode ser um indício de que podemos usufruir de uma metalinguagem em que o tempo tenha duas movimentações, como as duas metáforas descritas.

As expressões antes de e depois de também geram interpretações contraditórias. Clark afirma que talvez os termos mais interessantes para ver toda essa questão em inglês são before (antes de ou na frente de) e after (depois de ou atrás de). Vamos tentar entender o porquê, analisando duas frases em português. Na primeira (6), usaremos a tradução antes e depois para os termos before e after. Na segunda frase (7), usaremos a tradução na frente e atrás.

(6) Maria chegou antes de João e João chegou depois de Maria.

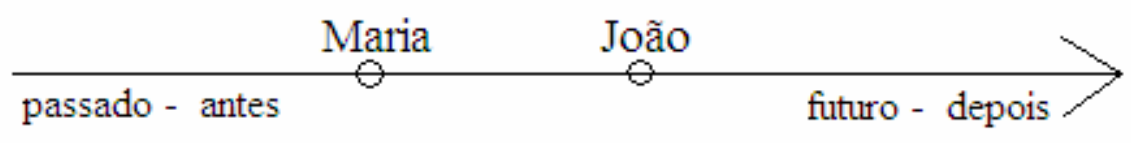

Figura 21 - Disposição do exemplo (6) em uma linha do tempo

(7) Maria chegou na frente de João e João chegou atrás de Maria.

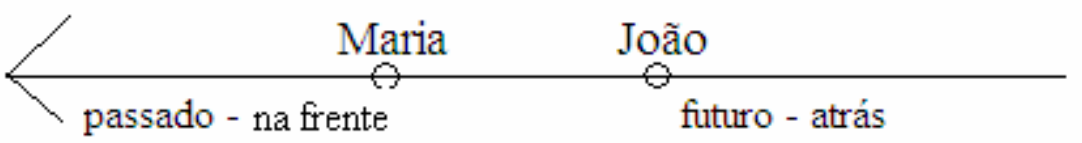

Figura 22 - Disposição do exemplo (7) em uma linha do tempo

A direção da linha do tempo da frase (6) se deu da esquerda para a direita. Entretanto, a direção da linha do tempo da frase (7) se deu da direita para a esquerda, pois, para que Maria continue chegando primeiro que João, mas usando os significados na frente e atrás, seria necessária uma linha do tempo que se toma como direção um futuro que vai para um passado.

A frase (6) utilizou a metáfora do ego movente para ser entendida, e a frase (7) utilizou a metáfora do tempo movente, pois se consideraram as seguintes informações para a construção das linhas do tempo: 
Quadro 1. As equações contrárias das metáforas do tempo

\begin{tabular}{|l|l|l|l|}
\hline Ego movente & para frente $=$ futuro & Tempo movente & para frente = passado \\
\cline { 2 - 2 } & para trás = passado & & para trás $=$ futuro \\
\hline
\end{tabular}

Como as duas metáforas do tempo são contraditórias, porque o ego movente se orienta da esquerda para a direita e tempo movente se orienta da direita para a esquerda, elas implicam equações contrárias.

Quanto às escolhas terminológicas para essas direções, Clark (1973) nos explica que a relação assimétrica - frente/trás - define um plano vertical no homem (bípede, ereto), indicado pela posição dos órgãos dos sentidos da visão, audição e olfato, que se projetam para frente e não para trás. Esse fator de percepção também sugere como o homem atribuiu valores à assimetria: já que o que está à frente é visto, e o que está atrás não pode ser visto (porque o homem caminha para a direção que ele encara, e não para o lado, ou para trás), "para frente", terá valor positivo, e "para trás", valor negativo.

Isto tudo significa que alguns termos da língua como antes e depois são projeções metafóricas feitas a partir do nosso próprio corpo. Mas esse tipo de reflexão sobre a linguagem, utilizando considerações corporais, é moderna. Antigamente, numa época orientada pelo Objetivismo, não se acreditava que aspectos corpóreos pudessem influenciar o nosso comportamento subjetivo. Entretanto, "Contrariamente à tradição cartesiana, a teoria de divisão entre mente e corpo não se sustenta dentro dos modernos estudos da neurociência." (ABREU, 2010, p.25). A teoria linguística cognitiva também leva em conta essas descobertas, entendendo a linguagem como "corporificada", a final, a faculdade da linguagem é vista hoje como integrante de outras faculdades humanas.

Nossa percepção da realidade é construída pelo formato do nosso corpo, pela maneira como ele se movimenta, pelo jeito como nossos sentidos percebem a realidade à nossa volta, pela forma como interagimos com o mundo, seus seres e objetos. [...]

É a partir do nosso corpo que criamos conceitos como frente, trás, esquerda, direita, alto e baixo. (ABREU, 2010, p.25-26) .

Vejamos mais duas frases ${ }^{24}$ para esclarecermos essas questões:

\footnotetext{
${ }^{24}$ Esses exemplos são inspirados nos exemplos de Clark: We will be in Paris in the days ahead (of now) e We will be in Paris in the days ahead of Christmas (1973, p.51), que poderemos traduzir, "ao pé da letra", por: Nós estaremos em Paris nos dias "à frente" (do agora) e Nós estaremos em Paris nos dias "à frente" do Natal.
} 
(8) O jogo acontecerá nos próximos dias.

(9) O jogo acontecerá nos dias seguintes ao carnaval.

Enquanto os "próximos dias" da frase (8) se estabelecem nos dias seguintes aos dias de hoje em que o ego está, os "dias seguintes" da frase (9) se estabelecem nos dias seguintes após o carnaval. Na sentença (8), o ponto de referência para refletirmos sobre quando o jogo acontecerá é o tempo em que o ego se encontra, ou seja, o tempo em que a frase foi enunciada. Então, a indicação "nos próximos dias" é feita na linha do ego movente, em direção ao futuro, a partir do ponto em que o ego está.

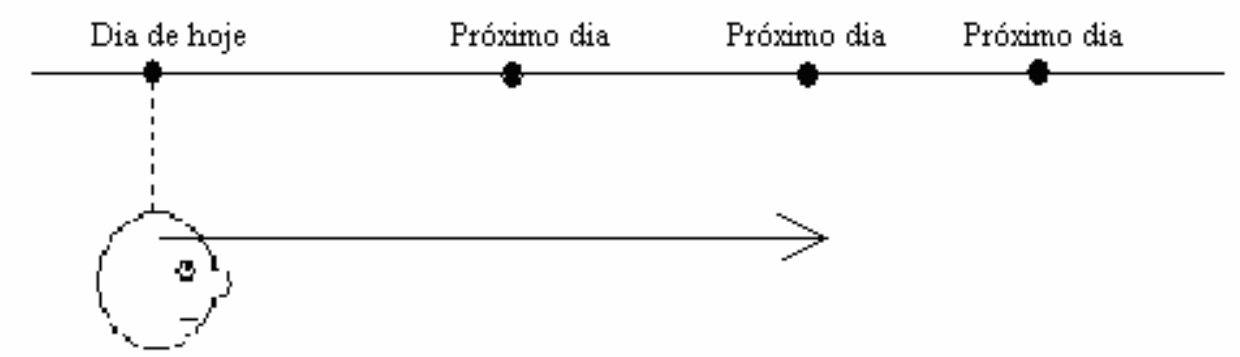

Figura 23 - O ego movente para "próximos dias"

Na sentença (9), a indicação ao carnaval não é feita na orientação do ego movente, mas na do tempo movente, porque a data do carnaval independe da marcação que o ego possa fazer. O carnaval é um ponto de referência, um dado cronológico, relativamente não-dêitico, e, por causa disso, é como se o falante "mandasse trazer", ao invés de "ir buscar" deiticamente, esse ponto de referência para perto de si, para poder fazer as outras relações e descobrir quando o jogo acontecerá. Ao fazer o tempo movente trazer a referência do carnaval para perto de si, o falante faz uma movimentação da sua atenção sobre o suporte temporal, que é a "estrada dos eventos discretos".

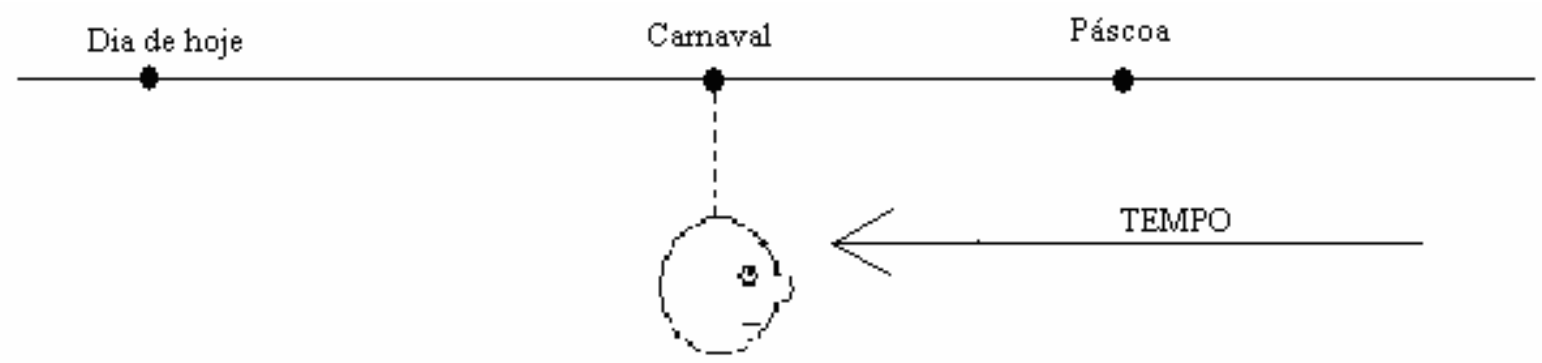

Figura 24 - O tempo movente para "carnaval"

Após trazer para si o tempo que se fez referência, o ego retoma a direção para o futuro: 


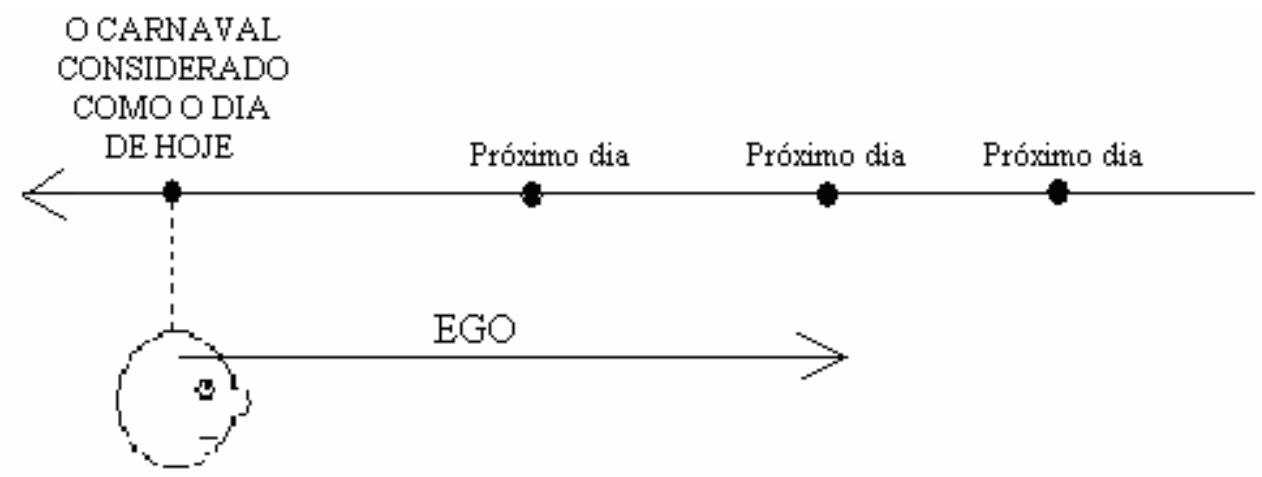

Figura 25 - O ego movente para "nos dias seguintes"

Assim, a sentença (9) era mais complexa que a sentença (8) porque precisou das duas visões do tempo: ego movente e tempo movente.

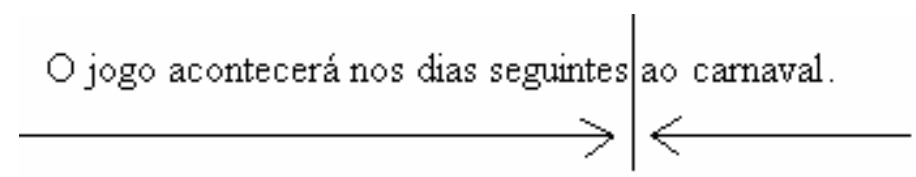

Figura 26 - Ilustração do enunciado (9) com setas indicadoras das metáforas de tempo

A diferença linguística que notamos nessas duas frases é que a primeira (8) é dêitica e a segunda (9) é não-dêitica (ou pelo menos não totalmente), porque toma como referência um marco cronológico - carnaval.

Concordamos com essa consideração de existirem dois pontos de vista sobre a localização: em um ponto de vista (o ponto de vista do ego), a localização temporal é feita com demarcações temporais estabelecidas pela movimentação do pensamento no tempo; no outro (o ponto de vista da estrada em movimento), a localização temporal é feita com demarcações temporais estabelecidas pela movimentação do tempo no pensamento. Quando a referência recai sobre o ego, a equação é a da metáfora do ego movente, quando a referência recai sobre os eventos em si, a equação utilizada é a metáfora do tempo movente. Com isso, podemos afirmar que sempre que temos uma frase dêitica, a referência recairá sobre o ego e quando não for dêitica, a referência recairá sobre algum evento narrativamente descrito. Dessa forma, a escolha da equação a ser usada não deverá ser tratada apenas como uma questão de ponto de vista porque dependeria sistematicamente do texto ser classificado como subjetivo ou objetivo.

Bechara (1984) diz que o ego, que ocupa o "centro ideal" do crivo espaciotemporalizador da língua, é o agente da enunciação, isto é, ele é quem dirige de forma adequada e precisa as expressões temporais das mensagens. 
$\mathrm{O}$ ponto EGO tem à sua frente o futuro, e às suas costas o pretérito: se o falante, nesse ponto, dirigir sua mente para o futuro, descreverá um movimento prospectivo (cinetismo prospectivo); se não, considera que apenas a linha do tempo exerce o movimento retrospectivo (cinetismo retrospectivo), vindo do futuro em direção ao passado. (BECHARA, 1984, p.65).

Poderíamos acrescentar a essa ideia mais algumas interpretações: o ponto ego localiza o ponto zero da enunciação; o futuro fica à direita e o passado à esquerda. Se o falante utiliza o momento da enunciação de forma dêitica, sua mente (o ego) estará orientada dirigindo-se para o futuro e deixando o passado. Se a mente (o ego) apenas quer testemunhar a enunciação, tornando-se o momento zero enunciativo apenas pressuposto, ela considerará apenas a linha do tempo que vem do futuro e vai em direção ao passado. Além disso, Bechara (1984) afirma que o movimento prospectivo (ego movente) gera um discurso subjetivo e o movimento retrospectivo (tempo movente) gera um discurso objetivo. Veremos que essas considerações serão adotadas para a descrição ilustrativa de dois grandes sistemas temporais do discurso: o enunciativo entendido como enunciação enunciada (discurso subjetivo) e o enuncivo entendido como enunciado enunciado (discurso objetivo).

A língua, portanto, consegue refletir em linguagem, como um simulacro, o tempo objetivo e o tempo subjetivo (figura 12). Ou seja, embora o tempo que opera na mente do homem seja o subjetivo porque deve seguir a entropia para que ele possua inteligência, passando por um trajeto do passado para o futuro, à medida que se lembra do passado, mas não se lembra do futuro, o homem consegue, com a linguagem, falar de um tempo que vai do futuro ao passado, ou seja, consegue falar de um tempo objetivo, que é o tempo por onde ontologicamente ele se insere no mundo, e consegue falar também de um tempo que vai do passado ao futuro e que não se confunde com o tempo subjetivo do esquema do tempo do mundo. Por esse motivo dissemos que o tempo da linguagem pode ser um simulacro do tempo geral, porque o homem opera discursivamente tanto com um tempo que pode ir do passado para o futuro, quanto com um tempo que pode ir do futuro para o passado. 


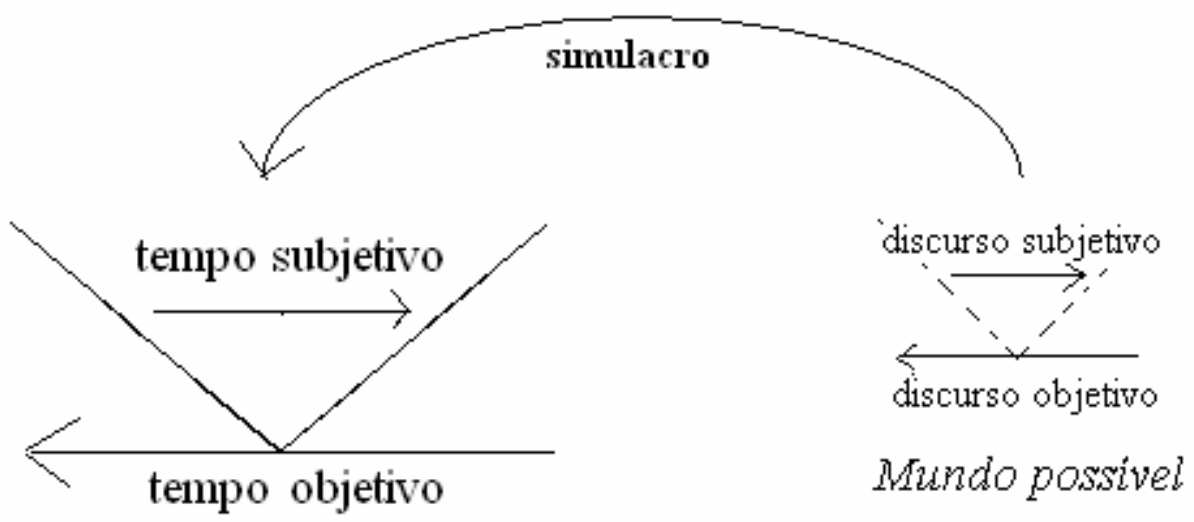

Mundo real

Figura 27 - A relação simétrica entre o modelo de tempo geral e o modelo de tempo linguístico

A simetria encontrada na ilustração descritiva do tempo criado pela linguagem otimiza as teorias analisadas e motiva a manutenção da figura 12 como ilustradora de um tempo geral do mundo.

Todas essas ideias vetoriais sobre o tempo podem ser úteis na nossa metalinguagem sobre o resgate mental da referência sobre a linha cronológica do tempo. Por exemplo:

(10) Nós estamos em Portugal no ano que vem.

(11) Colombo descobre a América em 1492.

Em cada um dos dois exemplos, notamos que há duas noções de tempo que não podem ser ligadas apenas por uma soma dos seus valores temporais. O agente enunciativo em (10) não pode estar no presente (estamos) e estar no futuro (no ano que vem) ao mesmo tempo, e o agente da enunciação em (11) não pode estar no presente (descobre) e estar no passado (em 1492) ao mesmo tempo, simplesmente porque não temos o poder na "onipresença enunciativa" do discurso. Mas o próprio tempo da língua é um suporte temporal que pode se deslocar mais para lá (futuro) ou mais para cá (passado) na linha do tempo, uma vez que ele é apenas reflexo do tempo real, e não representação direta deste. Como o sistema da língua permite uma movimentação do suporte temporal (tempo movente), pensamos em considerar esse mesmo tipo de movimentação nas construções linguísticas em que ocorre o uso de um tempo verbal não "esperado". 
Sobre a movimentação do suporte temporal, King (1983, p.107 apud Bechara, 1984), diria sobre o exemplo (10) que o falante "está trazendo o que é planejado para o futuro para dentro do presente", assim como "uma situação pertencente ao passado no tempo real também pode ser trazida ou 'puxada' para dentro da perspectiva presente do falante”. Elas são futuro e pretérito no tempo real, mas são “[...] simultâneas (incluídas na) perspectiva do presente do falante [...]". De maneira um pouco diferente, Castilho (1968) diria que é o sujeito quem se desloca em pensamento para o futuro, fazendo oscilar todo o sistema (1968, p.15-16). Concordamos com Castilho e diferimos de King, pois diremos, quanto a exemplos do tipo (10), que o falante estabelece como referência um momento futuro para a construção de sua "linha do tempo" gramatical, e não apenas o estabelecimento de um momento presente com características de futuro. Por outro lado, se assim quiséssemos, poderíamos tratar essa questão apenas como uma diferença de perspectiva, pois, de fato, após a movimentação do suporte temporal para o momento do ego, este, ao final, se encontra deslocado.

Nesse movimento de demarcação, vimos que o estabelecimento de pontos no tempo é demarcado ou com o ego ou com o próprio suporte temporal do ego (a estrada em movimento). As metáforas de Clark (1973), além de explicarem a situação etimológica de algumas expressões (como preceder, pósvocálico, etc.), ajudam a confirmar nossas intuições sobre o tempo objetivo e o tempo subjetivo, por serem muito parecidas visualmente com o nosso modelo do tempo geral da figura 12. Também esses dois movimentos podem explicar a questão do foco da referência temporal nas frases. Além disso, como veremos ao longo desse trabalho, as metáforas ilustram muito bem a fruição do discurso que sentimos ao lidarmos com um discurso temporalmente objetivo - mundo narrado - e com um discurso temporalmente subjetivo - mundo comentado.

\section{$3.2-$ A debreagem temporal}

A distinção entre dois tipos de tempo, que acabamos de ver, também pode ser observada em uma análise da temporalidade do discurso, na teoria da Semiótica Francesa, que também pensa nessa dupla distinção do tempo: a debreagem da enunciação e a debreagem do enunciado. 
As categorias do tempo (e também da pessoa e do espaço) passam do ato da enunciação para o texto pelo mecanismo da debreagem:

Debreagem é a operação em que a instância de enunciação disjunge de si e projeta para fora de si, no momento da discursivização, certos termos ligados à sua estrutura de base, com vistas à constituição dos elementos fundadores do enunciado, isto é, pessoa, espaço e tempo. (GREIMAS; COURTES, 1979, p.79).

Um referente extralinguístico projeta-se em um referente linguístico através de um shifting out, termo que veio de shifter, palavra inglesa introduzida por Jakobson, traduzida em francês por embrayeur. O termo shifting out e shifting in foram traduzidos para o francês, respectivamente, por débrayage e embrayage. Em português, diz-se debreagem e embreagem, respectivamente. "Debrear" é criar enunciados; é projetar o eu-aqui-agora da enunciação no enunciado. Essa projeção resulta em um não-eu, um não-aqui e um não-agora, porque "eu”, "aqui" e "agora" de um texto não são realmente a pessoa, o espaço e o tempo do ato de enunciar, mas a projeção destes numa enunciação que será sempre enunciada.

A debreagem temporal é a projeção, para fora da instância da enunciação, de tempos que servem para constituir o enunciado. Para Greimas e Courtès, a debreagem temporal é a transformação do tempo do sistema estrutural em discurso. Nela podemos construir ou um enunciado que é um simulacro da enunciação, em que se tem a ilusão de estar diante da temporalização do ato de dizer, ou um enunciado que não simula uma enunciação, em que se tem a ilusão de estar diante da temporalização dos eventos em si.

Podemos ter, portanto, em uma teoria do texto, duas temporalizações: uma da enunciação enunciada e outra do enunciado enunciado. Trata-se, no primeiro caso, da debreagem da enunciação, e, no segundo caso, da debreagem do enunciado (FIORIN, 2008, p.229-238).

O caráter subjetivo que um texto ganha ao nos contar os acontecimentos pode se dar em textos cujos acontecimentos se deram anterior, posterior ou concomitante ao presente da enunciação. O caráter objetivo causado pela forma de apresentar os acontecimentos, como se eles próprios ocorressem por si, só pode se dar em textos cujos acontecimentos se deram anterior, posterior ou concomitante ao presente da enunciação.

É necessário saber que a enunciação pode ser considerada num sentido mais "lato" (FIORIN, 2008). Assim sendo, poderíamos dizer que embora um enunciado enunciado seja considerado objetivo, ele pode apresentar marcas enunciativas mais "sutis", como os adjetivos e os advérbios apreciativos, a escolha lexical dos verbos, etc. São elementos que denunciam a 
"[...] presença do locutor no seio de seu enunciado, mostrando o que Benveniste chamava a subjetividade na linguagem (BENVENISTE, 1966, p.258-65).” (FIORIN, 2008, p.38).

Vamos, entretanto, trabalhar com a enunciação entendida no seu sentido "estrito", isso significa que será considerado enunciativo o que tiver manifestação expressa de projeção formal de tempo da enunciação enunciada.

Portanto, a teoria semiótica da debreagem se assemelha às visões subjetivas e objetivas do tempo, pois a debreagem da enunciação simula a temporalidade do ato de dizer (tempo subjetivo) e a debreagem do enunciado nos causa a "ilusão" de estarmos diante da temporalização dos eventos em si (tempo objetivo).

A debreagem enunciativa e a enunciva criam, em princípio, dois grandes efeitos de sentido: de subjetividade e de objetividade. Com efeito, a instalação dos simulacros do ego-hic-nunc enunciativos, com suas apreciações dos fatos, constrói um efeito de subjetividade. Já a eliminação das marcas de enunciação do texto, ou seja, da enunciação enunciada, produz efeitos de sentido de objetividade. (...) Lembramos que não existem textos objetivos, pois eles são sempre fruto da subjetividade e da visão de mundo de um enunciador. O que há são textos que produzem um efeito de objetividade. (FIORIN, 2003, p.178-179).

\section{3 - Mundo narrado vs mundo comentado}

A dicotomia mundo narrado vs mundo comentado pertence a Harald Weinrich (1968), e é inspirada na dicotomia discurso vs história de Benveniste (1995, p.260-276; 2006, p.76). Além de analisarmos essa dicotomia, também veremos a distinção entre sistema temporal enunciativo (tempos do agora) e sistema temporal enuncivo (tempos do então) de Greimas e Courtès (2008) e a análise sobre essa dicotomia feita por Fiorin (2008). Apenas para mencionar outras teorias que dividem o sistema temporal da linguagem em dois, temos a distinção feita por Culioli (1973), entre situação de enunciação e situação de enunciado; ainda a de Danon-Boileau (1982, p.95-8), entre referência por anáfora e referência por dêixis; em Fonseca (1992) encontramos referência dêitica primária e referência dêitica secundária (grosso modo, anafórica); e também a de $\operatorname{Imbs}(1968, \text { p.176-7 })^{25}$, entre sistema do agora e sistema do então.

\footnotetext{
${ }^{25}$ As referências às obras desses autores podem ser vistas em Fonseca (1992).
} 
Entendendo-se o construto MR (Momento de Referência) de Reichenbach como um construto que possui duas naturezas referenciais distintas, assim como as mencionadas acima - uma dêitica e outra não-dêitica -, acreditamos que poderemos explicar melhor o tempo linguístico por meio da teoria reichenbachiana.

Benveniste fala em dois tipos de enunciação caracterizados por um diferente tipo de relação entre a enunciação e o enunciado. Fonseca (1992) entende que Benveniste reconheceu que a categoria do tempo remete a dois diferentes planos de enunciação (história $v s$ discurso), e não apenas a diferentes grupos de tempos verbais. Diz, ainda, que na enunciação histórica, os acontecimentos parecem narrar-se a si mesmos. Weinrich retoma Benveniste na hipótese de dois planos de enunciação, reformulando a oposição histoire/discourse sob a forma de récit/commentaire.

Weinrich propõe que a função dos tempos verbais é indicar a atitude de elocução do falante que é ora uma atitude de tensão (comprometendo-se enunciador e enunciatário com a narrativa) ora uma atitude de relaxamento entre o enunciador e o enunciatário. Assim, divide em dois grandes grupos verbais as formas simples do indicativo: os tempos comentativos e narrativos.

Empregando os tempos comentativos, eu faço saber, ao meu interlocutor, que o texto merece de sua parte uma atenção vigilante [Gespanntheit]. Pelos tempos do narrativo, ao contrário, eu advirto que uma outra espécie de atenção, mais despreendida [Entspannheit], é possível. É esta a oposição entre o grupo dos tempos do mundo narrado e aquele dos tempos do mundo comentado que eu caracterizarei, globalmente, como atitude de locução ${ }^{26}$. (WEINRICH, 1973, p.30 apud PINTO, 2008, p.410).

Essa atitude é sentida por cada pessoa que faz uso da linguagem, ou seja, quem é "levado" pelo tempo objetivo da leitura ou quem é "trazido" pelo tempo subjetivo da leitura são os sujeitos particulares de uma comunicação, antes mesmo de serem considerados enunciador e enunciatário do discurso.

A distinção entre os dois sistemas temporais é caracterizada, em um primeiro plano, pelo diferente comportamento dos dêiticos. A relação desses dois tipos de enunciação com a dêixis temporal está marcada no âmbito dos advérbios e locuções temporais da seguinte forma:

\footnotetext{
${ }^{26}$ No original: En enployant les temps commentatifs, je fais savoir à mon interlocuteur que le texte mérite de sa part une attention vigilante [Gespanntheit]. Par les temps du récit, au contraire, je l'avertis qu'une autre écoute, plus détachée [Entspannheit], est possible. C'est cette opposition entre le groupe des temps du monde raconté et celui des temps du monde commenté que je caractériserai globalement comme attitude de locution.
} 
Quadro 2. Advérbios e locuções adverbiais dêiticos e anafóricos

\begin{tabular}{|l|l|}
\hline Dêitico & Anafórico \\
\hline Agora & Então \\
Hoje & Nesse dia \\
Ontem & Na véspera \\
Amanhã & No dia seguinte \\
No próximo ano & No ano seguinte \\
No ano passado & No ano anterior \\
Futuramente & Sucessivamente \\
Vinte anos atrás & Vinte anos antes \\
$(\ldots)$ & $(\ldots)$ \\
\hline
\end{tabular}

O ponto de referência das expressões dêiticas está interado na situação de enunciação. O ponto de referência das expressões anafóricas é interior ao próprio enunciado. Poderíamos dizer que é um tempo absoluto (dêitico) e um tempo relativo (anafórico), mas devemos ter cuidado, porque todo tempo é relativo ao momento da enunciação, mesmo o tempo dêitico.

É comum encontrarmos uma divisão dos advérbios de tempo e explicações como as que acabamos de trazer. Mas talvez uma classificação desse tipo possa ser ruim, pois os advérbios, quando utilizados junto com os verbos e com outras expressões de tempo, podem formar vários sentidos de tempo, e, portanto, limitar os advérbios - e também os verbos - a uma lista de dêiticos e não-dêiticos pode ser prejudicial em uma tentativa de descrição dos dois grandes planos temporais.

Fiorin (2008), baseando-se na teoria greimasiana, explica que existem dois sistemas temporais: um relacionado diretamente ao momento da enunciação e outro ordenado em função de momentos de referência instalados no enunciado. Temos um sistema enunciativo no primeiro caso e um enuncivo no segundo caso.

Os advérbios de tempo organizam-se em dois sistemas: um enunciativo e outro, enuncivo. Este serve para indicar as relações de concomitância, anterioridade e posterioridade organizadas tanto a partir de um marco temporal pretérito quanto de um momento de referência futuro. Por exemplo, os advérbios hoje, ontem e amanhã indicam o dia concomitante, o anterior e o posterior, respectivamente, em relação ao momento da enunciação. No entanto, se se for indicar a concomitância, a anterioridade e a posterioridade a um marco temporal pretérito ou futuro, empregam-se, respectivamente, no mesmo dia, na véspera ou no dia anterior e no dia seguinte. Os adjuntos adverbiais construídos com o adjetivo próximo são 
enunciativos e os elaborados com o adjetivo seguinte são enuncivos. (FIORIN, 2007, p.8).

Observemos melhor a distinção entre mundo comentado e mundo narrado. Weinrich (1968) diz que podemos ter duas situações comunicativas:

- Mundo comentado: estabelece-se uma atitude tensa, tornando o discurso dramático. É o falante comprometido. Nas palavras de Weinrich, comentar é falar comprometidamente. O comentário afeta o ouvinte exigindo dele uma reação. Nessa situação comunicativa, Weinrich analisou que, em língua francesa, são empregados verbos do presente do indicativo, pretérito perfeito composto e futuro do presente composto. Estes são tempos verbais que formam um grupo dos verbos do mundo comentado e que, se encontrássemos equivalentes em língua portuguesa, chegaríamos muito próximos dos tempos verbais que Fiorin (2008) diz comporem as formas modotemporais do sistema enunciativo;

- Mundo narrado: estabelece-se entre os interlocutores uma atitude mais relaxada. O destinatário é simples ouvinte. Weinrich mostrou que, em língua francesa, são empregados verbos do pretérito perfeito simples do indicativo, pretérito imperfeito, pretérito mais-que-perfeito e futuro do pretérito. Estes tempos verbais formam o grupo dos verbos do mundo narrado, e se encontrássemos equivalentes em língua portuguesa, chegaríamos muito próximos dos tempos verbais que Fiorin (2008) diz comporem as formas modo-temporais do sistema enuncivo.

Fonseca (1992) também vê a comunicação com essas duas sensações, e diz que o locutor “[...] vive num estado de tensão que lhe augura uma vida curta, se não for reconhecido que fazem parte da sua competência de falante dimensões que the permitem incluir, na actividade linguística, momentos de distensão."27 (FONSECA, 1992, p.29). Quando ocorre a distensão, é porque houve uma suspensão do dispositivo de comunicação dêitico. Existem "[...] formas de uso da linguagem em que se suspende, em grau maior ou menor, a referência directa a um contexto presente [...]" (FONSECA, 1992, p.31).

Quanto aos outros modos temporais, Weinrich considera subjuntivo, imperativo, infinitivo, gerúndio e particípio como semitempos porque, como eles não aparecem isolados,

\footnotetext{
${ }^{27}$ Fonseca (2002) fundamenta sua distensão sobre a mesma distensão de Weinrich, para o mundo narrado.
} 
dependem do apoio de formas completas de tempo. É da relação daquelas outras formas de tempo verbal na língua com formas completas que inferimos na linguagem qual a situação comunicativa se expressa: se de mundo comentado ou mundo narrado. Por isso essa abordagem é interessante, porque ela vai além do estrutural, ela toma como referência os tipos de organização do discurso.

\subsubsection{A metáfora temporal}

Quando se usa um verbo do mundo narrado para comunicar uma situação de mundo comentado, ou, ao contrário, quando se usa um verbo do mundo comentado para comunicar uma situação de mundo narrado, ocorre o que tradicionalmente se chama de metáfora temporal, que consiste em comentar como se estivesse narrando ou narrar como se estivesse comentando (PONTES-RIBEIRO, 2007, p.27). Por exemplo:

(12 a) - Mãe, hoje eu sonhei que o papai morreu!

b) - Mãe, eu também sonhei que o Dr. Sebastião também morr... tinha morrido!

O sujeito de (12) sonhava com as duas situações, a morte de seu pai e do doutor. Ele estava presenciando uma situação de comentário dentro do sonho, em que as duas pessoas do nosso exemplo eram falecidas. Ao acordar, o sonho pode ser interpretado como uma situação narrativa, uma vez que o sonho foi um acontecimento não-real e passado. Entretanto, ao proferir (12 a), o interlocutor presentifica a situação passada de seu sonho, comprometendo sua mãe, interlocutária dessa comunicação, a participar de uma falsa realidade de que a morte do pai seria algo de um mundo comentado (morreu, pretérito perfeito) assim como o foi durante o seu sono. Na frase (12 b), o interlocutor não quer se comprometer em continuar dizendo que o que foi um fato no sonho (a morte do doutor) pode, mesmo de brincadeira, continuar valendo temporalmente para o mundo real. Ele passa, então, a narrar (e não a comentar) o sonho em (12 b).

Em (12 a), poderíamos dizer que ocorreu uma metáfora temporal: usou-se um tempo do mundo comentado para expressão de uma situação de mundo narrado.

Não é muito difícil ouvirmos o seguinte tipo de frase: 
(13) -Vamos, agora, homenagear o nosso querido Mussum que há dez anos nos deixava.

Em (13), o fato de Mussum ter morrido é narrado e não comentado, porque se usou um tempo do mundo narrado, o pretérito imperfeito. Normalmente, comentamos a morte de alguém, e, então, usamos os tempos do mundo comentado:

(14) O nosso querido Mussum que nos deixou há dez anos.

Podemos dizer, então, que houve uma metáfora temporal em (13): usou-se um tempo do mundo narrado para expressão de uma situação que normalmente é relatada por um mundo comentado.

As metáforas temporais são provas de que o uso de um enunciado dêitico ou nãodêitico não é determinado pelo seu conteúdo, mas pela perspectiva enunciativa que se deseja transmitir, adotando uma atitude tensa ou distensa.

A diferença entre mundo narrado e mundo comentado também pode ser vista nos seguintes exemplos, da modalidade oral:

(15) Paulo disse que virá amanhã.

(16) Paulo disse que viria amanhã.

Em (15) comenta-se o fato da vinda de Paulo; em (16), narra-se o que Paulo disse. Exemplos desse tipo são normalmente explicados por meio da noção de modalização. Por exemplo:

Há uma diferença de modalidade, isto é, há duas atitudes: um distanciamento e um envolvimento.

No primeiro exemplo (virá), eu me engajo com esse fato, assumo-o como um compromisso, com a realização disso. É uma ancoragem no presente. $E u$ (produtor dessa enunciação) estou no presente e ele, no passado. $\mathrm{O}$ personagem da enunciação sou eu. $E u$ me coloco como fiador dessa promessa: ele prometeu e eu afianço o que ele falou. Muda-se aí o ponto de referência, a ancoragem.

No segundo caso (viria), é só a palavra dele, só um ponto de referência dele; eu, como enunciador não tenho nada com isso. Inclusive a ancoragem é só no passado. Há um distanciamento, uma neutralidade do locutor na realização desse fato. (PONTES-RIBEIRO, 2007, p.29-30). 
Essa relação dicotômica entre distanciamento e envolvimento pode ser a mesma entendida por Weinrich entre tensão e "relaxamento".

O que permite uma classificação por comentado ou narrado depende da intenção do falante.

- $\quad$ optar por uma construção de um mundo narrado é querer exprimir, por exemplo, e dependendo do contexto, matiz de validez limitada, falta de comprometimento com o que é dito, compromisso menor entre os atores da comunicação, falta de engajamento, distanciamento entre os atores da comunicação, irrealidade ou cortesia;

- $\quad$ optar por uma construção de um mundo comentado é querer exprimir maior comprometimento com o narrado, falta de cortesia, caráter de verdade naquilo que é dito, aproximação entre a atenção de quem recebe o enunciado.

Por exemplo, se temos que dar uma notícia ruim a alguém, como:

(17) Hoje acordei descontente e resolvi que minha infelicidade está relacionada a você. Eu vim aqui para terminar nosso namoro, e espero que me compreenda!

podemos, por querermos atenuar o teor da mensagem, por cortesia, escolher contar ao nosso destinatário o conteúdo dessa notícia em forma de uma pequena história. Por exemplo:

(18) Um belo dia, eu acordei descontente e resolvi que minha infelicidade estava relacionada ao meu namorado. Decidi que na noite daquele dia eu iria até a sua casa e terminaria o namoro! E estou rezando para que ele me compreenda!

Esse exemplo pode, em um primeiro momento, parecer estranho em uma conversa face a face, entre o namorado e a namorada, mas é muito comum encontrarmos esse tipo de construção retórica.

Podemos perceber, então, que embora um determinado texto pertença ao presente da enunciação, de acordo com a sua referência semântica, o texto está escrito de forma a fazer uma referência a uma realidade discursiva que não corresponde a um presente da enunciação, mas a um passado no enunciado. Essa aparente contradição é uma prova de que a forma como expomos nossas ideias sobre o tempo dependem - em grande parte, mas não totalmente, como veremos - da nossa intenção. 
Vamos fazer mais algumas considerações sobre o mundo narrado. Fonseca (1992) afirma que a atividade de narrar é, quando ao se falar, num "aqui-agora", de um "outro aquiagora", refere-se a um "lá-então". Essa atividade de narrar é feita usando-se o sistema enuncivo da língua. O sistema enuncivo está mais distanciado da instância da enunciação porque provoca uma ilusão de independência deste. Está indiretamente ancorado na situação de enunciação e se apresenta, assim, como fictivamente autônomo em relação ao contexto em que é produzido, ou seja, está fictivamente desinserido da instância enunciativa. Essa autonomia é que acaba trazendo ao sistema enuncivo um caráter objetivo.

É uma ilusão porque, de fato, o falante não pode separar-se de um "aqui" e de um "agora" que se movem consigo e que, a cada vez que diz "eu", institui como coordenadas geradoras da configuração de um mundo - o mundo "atual" ou mundo zero do agora ${ }^{28}$. Isto significa que o tempo do então está subordinado ao tempo do agora. Mas

O homem pode, ao usar a linguagem e só porque a usa, desenraizar-se fictivamente da sua situação de enunciação, "deslocando-se" a si próprio e ao seu interlocutor no tempo e no espaço: "Era uma vez...", a fórmula do conto maravilhoso, é uma das manifestações mais evidentes desta forma de utilização da linguagem verbal. (FONSECA, 1992, p.35).

Essa subordinação também pode ser encontrada nessa passagem: “[...] preso a um 'aqui-agora' que transporta consigo, o sujeito falante tem, no entanto, a possibilidade de (re)criar um 'outro aqui-agora', isto é, um 'lá-então'." (FONSECA, 1992, p.36). Ou seja, mesmo quando se tem criado um texto enuncivo, está transportado com ele um tempo enunciativo. Prova disso é que sempre poderemos encontrar marcas da enunciação enunciada, como os adjetivos apreciativos nos discursos, mesmo que sejam discursos temporalmente enuncivos.

A concepção de tempo movente de Clark (1973), como vimos, é também objetiva e, grosso modo, independe do "ego-pensante". Ela, por isso mesmo, simula o tempo das coisas como elas se dão perceptivelmente ao homem: como algo que está vindo do futuro, algo que é presente no momento, e algo que acabou de ser passado. Por esse motivo, quando usamos a metáfora do tempo movente dizemos que o foco está nos eventos e não no agente da enunciação (o ego).

Vamos fazer mais algumas considerações sobre o mundo comentado. Podemos dizer que, no mundo comentado, 'É a partir de uma 'origo' constituída pelas coordenadas enunciativas (eu-aqui-agora) que se desenha, na mostração 'ad oculos', um campo mostrativo

\footnotetext{
${ }^{28}$ Há um mundo zero do então (GREIMAS; COURTÈS, 2008, p.266).
} 
em que é possível 'apontar' para objetos e circunstâncias." (FONSECA, 1992, p.91). Portanto, isso pode se assemelhar à outra forma de concepção do tempo, a metáfora do ego movente de Clark (1973). Nesta metáfora, como vimos, há um ego explícito e que está ancorado num "campo mostrativo", pois se diz que o cinetismo ascendente é aplicado sobre o cinetismo descendente fundamental (espécie de campo mostrativo):

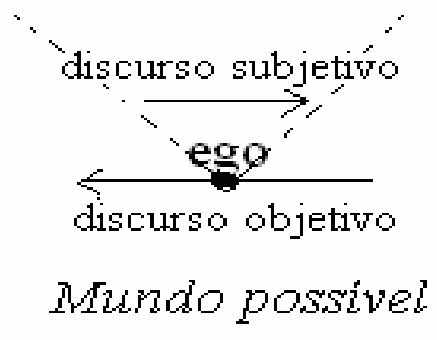

Figura 28 - O modelo do mundo possível

Nessa figura, percebemos que o ego, instalado no tempo do discurso objetivo, projeta o tempo do discurso subjetivo. Como vimos, embora o tempo do então esteja "ligado" ao tempo do agora, o discurso temporalmente objetivo provoca um distanciamento da instância da enunciação por meio de uma ilusão de independência deste. A ancoragem se dá "sutilmente" e por isso o ego pode parecer autônomo em relação à instância enunciativa. Por isso, na nossa ilustração 28 optamos por deixar os indicadores de projeção do discurso subjetivo menos perceptíveis (linhas pontilhadas), pois nossas ilustrações, neste momento, buscam uma representação da temporalidade da linguagem e não da temporalidade do discurso (que sempre irá pressupor um enunciador). Para nós, o tempo pode ser apresentado ora objetivo ora subjetivo, sem indicação de subordinação, respeitando a intencionalidade do locutor que vai decidir ou por um discurso objetivo ou por um discurso subjetivo.

O tempo criado pelo mecanismo do mundo narrado possui uma objetividade sentida como um fluxo distenso no tempo, como um fluxo de informações que vão passando por nós do futuro ao passado. O tempo criado pelo mecanismo do mundo comentado possui uma subjetividade sentida pela nossa consciência de que estamos fincados em uma linha do tempo, e, portanto, tem a nossa visão para frente, numa orientação que segue do passado para o futuro. Comparando-se esses dois mundos com os dois cinetismos de Molho (1975), conseguiremos mais comprovações dessas aproximações que estamos fazendo. De acordo com Bechara (1984), o cinetismo prospectivo (ascendente - Molho) caracteriza o tempo subjetivo, enquanto o cinetismo retrospectivo (descendente - Molho) caracteriza o tempo objetivo. Por esse motivo assemelhamos esses dois movimentos aos dois sistemas do tempo 
porque estes podem ser um simulacro do tempo do mundo, demonstrado na figura 27 . $\mathrm{O}$ tempo do mundo narrado "passa por nós" como o tempo da vida (tempo objetivo) e o tempo do mundo comentado, localizado deiticamente em algum ponto do tempo objetivo, transcorre como o tempo subjetivo.

Se analisarmos os exemplos:

(19) O jogo acontecerá nos próximos dias.

(20) O jogo acontecerá nos dias seguintes ao carnaval ${ }^{29}$.

vamos lembrar que as metáforas do ego movente e do tempo movente podem ilustrar o sistema enunciativo e o sistema enuncivo: "próximos dias", que é uma expressão dos tempos enunciativos, por ser de caráter dêitico, como vimos, faz o nosso pensamento andar pelo tempo (metáfora do ego movente); e carnaval, que é uma marcação cronológica, não-dêitica, enunciva, faz com que seja o tempo quem caminhe em nosso pensamento (metáfora do tempo movente).

\section{4 - O tempo "distendido": a enunciação}

Devemos reconhecer que o chamado tempo da morfologia de uma língua não entra em uma relação simples e direta com o que chamamos tempo no plano existencial. Uma das provas disso é que, em várias línguas, há termos distintos para o tempo linguístico e para o tempo enquanto fenômeno da natureza. Por exemplo, no inglês tense e time, e no alemão tempus e zeit ${ }^{30}$, significam, respectivamente, tempo linguístico, e tempo real.

Os estudos gramaticais do tempo, em geral, não deixam explícito que o tempo linguístico é apenas um simulacro do tempo verdadeiro. Por não deixar explícito, o efeito que se tem é do tempo linguístico ser igual ao tempo do mundo. Para que tenhamos explícito que o tempo da língua é sempre um simulacro do tempo do mundo, precisamos sempre fazer a ponte entre mundo real e mundo possível criado pela linguagem. Essa ponte se chama enunciação,

\footnotetext{
${ }^{29}$ Esses exemplos são os mesmos exemplos (8) e (9) vistos anteriormente.

${ }^{30} \mathrm{Na}$ verdade, além do termo zeit (tempo cronológico), existem outros termos em alemão para designar o tempo enquanto fenômeno da natureza, como o termo wetter que significa tempo atmosférico.
} 
que "[...] é este colocar em funcionamento a língua por um ato individual de utilização." (BENVENISTE, 2006, p.82).

Essa questão prova que a natureza do tempo é dêitica. Para Lyons, "a tradicional discussão sobre a categoria gramatical do tempo não apresenta ênfase suficiente para o fato de que ela é uma categoria dêitica, e costuma ser misturada com outras questões."31 (LYONS, 1977, p.677).

Como pudemos perceber na figura 15, o tempo da língua (tempus ou tense) não está sobreposto ao tempo subjetivo (zeit ou time), ele está localizado apenas em um ponto na linha do tempo subjetivo, e a partir deste ponto, o tempo linguístico se projeta para algo contínuo (como a metáfora da estrada contendo eventos discretos de Clark). Entretanto, não podemos esquecer que, por trás desse ponto, está um falante que, operando com o sistema linguístico, está também fazendo com que sua seta subjetiva do tempo perpasse pelo seu cérebro, tornando tudo que vai sendo enunciado anterior em relação ao discurso, e este só poderá ser resgatado pela memória; e tudo que ainda vai ser enunciado, posterior em relação ao discurso, sendo entendido como uma expectativa. Ou seja, não podemos esquecer que há uma orientação do passado para o futuro que é a do ato linguístico. Temos a produção enunciativa e, a partir dela, o discurso.

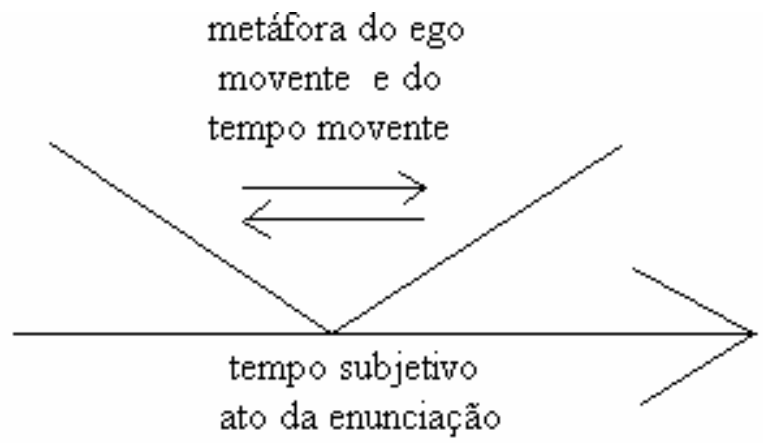

Figura 29 - A localização das metáforas do tempo no tempo subjetivo

Esta distinção se parece com a distinção feita por Santo Agostinho entre Temporalização e Aspectualização. Vamos resgatar a figura utilizada:

\footnotetext{
${ }^{31}$ No original: Traditional discussions of the grammatical category of tense do not give sufficient emphasis to the fact that it is a deictic category; and they tend to be misleading in other respects also.
} 


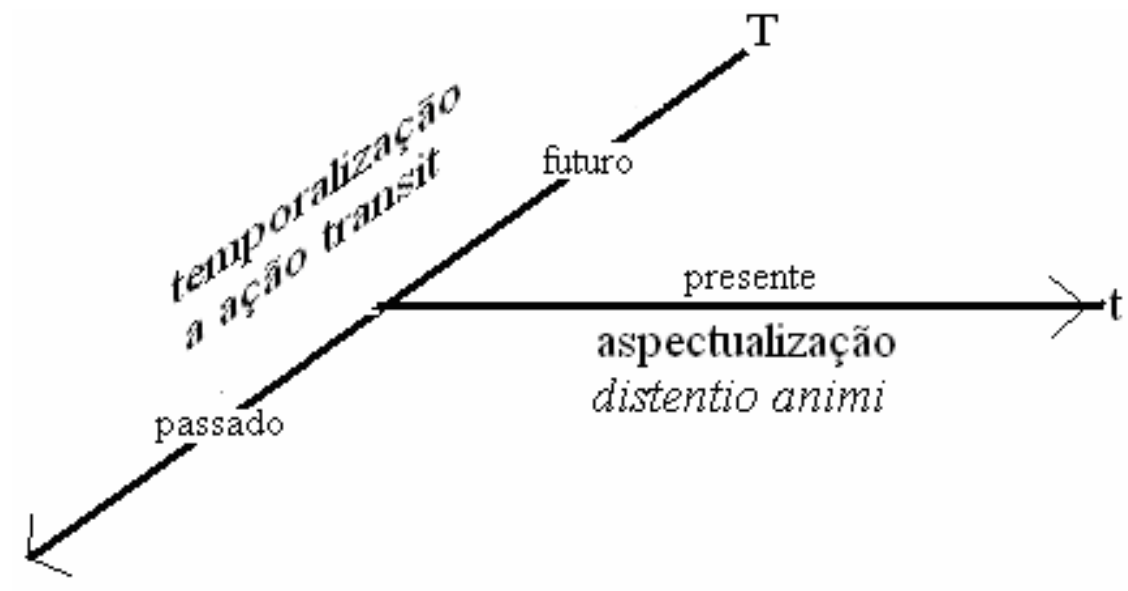

Figura 30 - Temporalização e Aspectualização de Santo Agostinho ${ }^{32}$

A diferença entre a figura 29 e a figura 30 é que a nossa 29 não demonstra mais a seta do tempo objetivo, na qual o homem está inserido, e na demonstração feita sobre as ideias de Santo Agostinho, na figura 30, apresentamos o tempo objetivo através da seta (T) de onde surge a seta da aspectualização (a da alma do homem). Como dissemos, o conceito de aspectualização de Santo Agostinho parece estar fundamentado nos conceitos modernos de enunciação. Nesse sentido, enunciar é produzir um discurso cuja compreensão leva a um caminho de entropia no tempo, correspondendo esquematicamente à linha do tempo da aspectualização agostiniana, que aumenta do passado para o futuro. Entretanto, o produto dessa enunciação ou nos "trará" semanticamente para um mundo em que se aproximam enunciador e enunciatário (textos temporalmente enunciativos) ou nos "levará" semanticamente para um mundo que segue a linha do tempo como um simulacro de ações humanas, por não pretender que o enunciatário se prenda ao enunciador. E, completando essa questão com nossa proposta esquemática, o discurso entendido temporalmente como enunciativo terá uma direção do passado ao futuro, enquanto o discurso entendido temporalmente como enuncivo, terá uma direção do futuro ao passado.

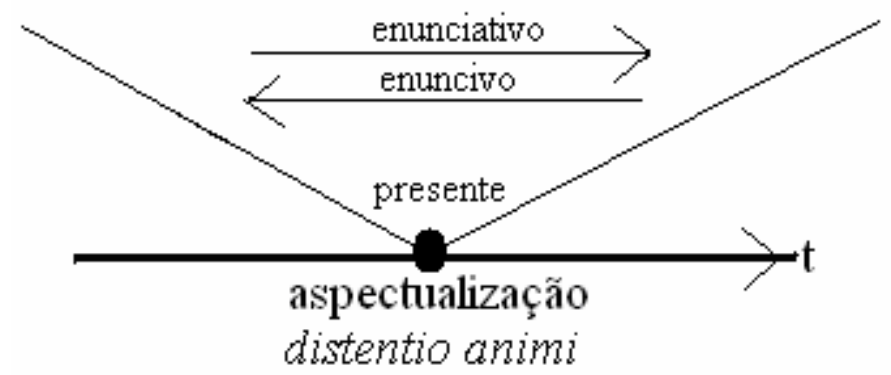

Figura 31 - Os tempos enunciativo e enuncivo como formas de distentio animi

\footnotetext{
${ }^{32}$ A figura 30 é a mesma figura 3 vista anteriormente.
} 
Lembramos que do ponto de vista discursivo, as duas setas estão subordinadas uma a outra, como se constatou na figura 28.

Com essa figura da aspectualização, que funcionaria, segundo Santo Agostinho, como uma "distenção", de um presente na alma, ampliamos - por meio da mesma ideia da projeção de um vértice angular - o que acontece dentro de cada momento "distendido", para mostrar, esquematicamente, que falamos temporalmente ora de um texto enunciativo, ora de um texto enuncivo.

Ainda hoje, no Brasil, os estudos linguísticos que cobrem o campo do fenômeno da enunciação não foram sistematizados. Flores e Teixeira (2005), que se preocuparam em esclarecer a confusão teórico-metodológica “[...] nesse terreno minado que é o campo da enunciação [...]" (FLORES; TEIXEIRA, 2005, p.11), gostariam de ver esse campo sistematizado de forma que tivéssemos uma única Linguística da Enunciação, e esta compreendesse mais de uma - coexistindo várias - teoria da enunciação. Nosso trabalho utilizou as ideias de enunciação que recobrem a "situação de comunicação", para analisarmos o tempo referencial não-linguístico, e a teoria greimasiana sobre a enunciação enunciada, para estudar o tempo do discurso.

Neste capítulo sobre o tempo da linguagem, precisamos recorrer à teoria da enunciação de Benveniste, porque precisamos de uma teoria que explique como o tempo do mundo real passa para um tempo da linguagem e, como ainda se fala em um mundo real, porque é deste que se parte para uma concepção do discurso, poderemos discutir o contexto referencial nãolinguístico da situação de comunicação. Em outras palavras, a enunciação pressuposta, que é aquela representada por um eu sempre presente e que perpassa por todo o discurso, deve ser analisada também nesse capitulo sobre o tempo da linguagem porque ela faz parte de uma entidade real (aquele que enuncia pressupostamente) e uma entidade discursiva (o discurso que o presente pressuposto reproduz).

Émile Benveniste é considerado o linguista da enunciação e o principal representante do que se convencionou chamar de teoria da enunciação. Para Benveniste, enunciar é colocar em funcionamento a língua por um ato individual de utilização. Enunciar é transformar individualmente a língua - mera virtualidade - em discurso. A semantização da língua se dá nessa passagem. A enunciação, vista desse prisma, é produto de um ato de apropriação da língua pelo locutor. Quando o locutor mobiliza a língua, ele estabelece uma relação com o mundo por meio do discurso, enquanto, do outro lado, o alocutário co-refere.

$\mathrm{O}$ ato de referenciar é que cria "um mundo" a ser referenciado, porque ao enunciar entram em jogo basicamente três categorias enunciativas: pessoa, espaço e tempo, elementos 
capazes de recriar um mundo a partir da instância do ego, hic, nunc ${ }^{33}$, e o tempo se ordenaria, na língua, a partir de coordenadas criadas na instância do discurso. Portanto, a referenciação de Benveniste deve ser estudada dentro dos estudos estruturais de uso da língua, porque é só com o uso que há enunciação e é só na enunciação que há essa referência.

A natureza do tempo da linguagem é enunciativa porque é uma extensão, ou "distensão", da alma (distentio animi) necessária para a sua realização. O ato de fala gera um agora (do enunciador e do enunciatário), que se organiza num eixo ordenador de tempo que é sempre igual a zero. A organização linguística fica por conta de um eu sempre subentendido, e que se identifica com o que chamamos neste trabalho de tempo subjetivo, porque é deste que se projeta o discurso. Este eu subjetivo, por sua vez, pode manifestar-se através de um tempo concomitante ou não-concomitante.

Fiorin (2007, p.3), a partir das ideias de Benveniste, ao explicar como se dá a relação entre tempo linguístico e tempo físico (cronológico), diz que:

A radical originalidade do tempo lingüístico é que ele se constitui no ato de tomar a palavra, na enunciação. O momento em que o eu enuncia é o agora e, a partir desse momento, constitui-se o tempo lingüístico (BENVENISTE, 1974, p.73). O agora é recriado a cada momento em que o enunciador toma a palavra. Por isso, o momento da enunciação não pode ser localizado em nenhuma divisão particular do tempo cronológico, uma vez que ele as admite todas e não exige nenhuma (BENVENISTE, 1974, p.74). A temporalidade do enunciador é aceita pelo enunciatário. Por conseguinte, o agora do enunciador é o agora do enunciatário. É isso que garante a inteligibilidade da localização temporal dos acontecimentos.

O nível da imanência passa para a língua por meio da enunciação. Trata-se da mesma passagem que vimos anteriormente, aquela em que o tempo da linguagem se fixa em um ponto do tempo do mundo.

A enunciação é então vista, como aliás já o tinha feito Benveniste, como instância de mediação, que assegura a discursivização da língua, que permite a passagem da competência à performance, das estruturas semióticas virtuais às estruturas realizadas sob a forma de discurso. (Greimas e Courtès, 1979, p.126). (FIORIN, 2008, p.36).

No próximo capítulo, trataremos do tempo do discurso. O tempo gramatical se refere a uma realidade discursiva porque não pode ser previsto ou fixado, pois é definido na própria instância do discurso, referindo a uma realidade distinta a cada vez que é enunciado. Entra nessa questão do tempo do discurso uma outra teoria enunciativa - a de Greimas - que não se atém às informações não-linguísticas (contexto referencial), ou seja, a uma "situação de

\footnotetext{
${ }^{33}$ Expressão latina que significa eu, aqui e agora.
} 
comunicação", de contexto "pisicossociológico" da produção dos enunciados (GREIMAIS; COURTÈS, 2008, p.166).

\section{5 - A Teoria Cognitiva dos Espaços Mentais}

No primeiro capítulo, dissemos que para fazer referência a um dos lugares temporais da linha do tempo, precisamos estabelecer pequenos espaços de tempo, à semelhança de um filme, que é composto por várias cenas. Esses espaços de tempo podem ser entendidos como espaços mentais, em uma teoria cognitiva. A teoria dos Espaços Mentais (Mental Spaces) foi proposta por Gilles Fauconnier (1984) em sua Teoria Cognitiva. Abreu (2010, p.81) em seu livro Linguística Cognitiva: uma Visão Geral e Aplicada, explica-nos, de forma clara, o que são os espaços mentais:

No momento em que entramos em contato com um texto falado ou escrito, abrimos, imediatamente dentro de nossas cabeças, pequenos "programas online" vinculados ao nosso conhecimento de mundo, para atribuir sentido a ele. Espaços mentais são, portanto, pequenas parcelas de tempo de curta duração que abrimos em nossas mentes, para atribuir sentido ao que ouvimos ou lemos. Embora esses espaços trabalhem com nossa memória operacional ou de curto prazo, buscam, a todo o momento, informações em nossa memória de longo prazo, em nosso conhecimento enciclopédico de mundo assimilado durante nossa existência.

A teoria dos espaços mentais está relacionada à concepção do linguísta Turner (1996) sobre o processo de significação. De acordo com Turner, as palavras por si mesmas não representam sentidos; somos nós que damos suporte para que as palavras signifiquem, pelo sentido que atribuímos dentro das nossas mentes.

Um espaço mental é um "pacote conceitual" (conceptual packet) que se constrói online no curso da comunicação. Os acessos aos espaços mentais são extremamente rápidos. Nós vamos buscar no nosso conhecimento enciclopédico de mundo a localização desses espaços de forma on-line, ou seja, nós participamos da construção de sentido do discurso, pois "Os significados não estão nas palavras ou nos enunciados; os significados são criativamente construídos pelos falantes e ouvintes.” 34 (KÖVECSES, 2006, p.268).

\footnotetext{
${ }^{34}$ No original: Meanings are not in the words or sentences; meanings are creatively constructed by speakers and hearers.
} 
Tanto essa ideia quanto a ideia da enunciação, que acabamos de tratar, podem ser vistas em Santo Agostinho. Se nos lembrarmos do que vimos sobre o seu conceito a respeito das divisões de tempo, veremos que o filósofo disse que o futuro (espera), o passado (memória) e o presente (atenção) só existem enquanto existem na alma, de onde podemos entender que só existem enquanto os acessamos mentalmente.

Para compreender temporalmente um texto de uma notícia de jornal, revista ou obra literária, precisamos saber acompanhar vários espaços mentais criados. Precisamos tratar a ideia dos espaços mentais como um pacote conceitual mais amplo que englobe outros espaços não tão amplos; depois, como em um mapa, o trabalho cognitivo é acompanhar esses mundos cognitivos, que são um outro uso da teoria dos Espaços Mentais (KÖVECSES, 2006, p.266267). Vejamos, como exemplo, a seguinte reportagem de revista:

Poucos meses após dar à luz os gêmeos Knox Leon e Vivienne Marcheline, na França, Angelina Jolie está de volta ao corpo magro e anguloso de antes. Como fez isso? "Tenho seis filhos e amamento!", diz ela, 33 anos que parecem 20, sorrisão, Ralph Lauren da cabeça aos pés - calça e malha bege-clarinha e sapatos de salto de 7 centímetros. No luxuoso hotel Waldorf Astoria, em Nova York, a atriz está recebendo jornalistas do mundo todo, que vieram saber um pouco mais sobre seu novo filme, $A$ TROCA, dirigido por Clint Estwood, e que estréia no Brasil em 2 de fevereiro.

No drama, baseado em fatos reais, Angelina interpreta Christine Collins, telefonista e mãe solteira em Los Angeles, nos anos 20, que um dia volta do trabalho e não encontra o filho. Walter Collins tinha 7 anos quando desapareceu de casa. A história piora: meses depois, a polícia anuncia que encontrou o menino e chama a imprensa para registrar o encontro, mas a mãe não o reconhece. Na época, a polícia de Los Angeles era tão corrupta que fazia qualquer negócio para que ninguém investigasse suas falcatruas. Só que essa mãe quer a verdade, custe o que custar. Contar mais é estragar a história. Basta dizer que os críticos prevêem uma segunda indicação ao Oscar para Angelina, que levou o prêmio de coadjuvante em 2000 por GAROTA, INTERROMPIDA. A atriz conta que fazer $A$ TROCA teve para ela uma "função terapêutica", pois ajudou-a a superar a dor da perda de sua mãe, Marcheline, que morreu em janeiro de 2007. "Posso dizer que mais ou menos representei minha mãe nesse filme. É ela que vejo quando assisto ao filme, e Brad a vê também." (CLAUDIA, No1, Ano 48, Janeiro 2009, p.42)

Para entendermos este texto temporalmente, precisamos ir organizando alguns espaços mentais: primeiro precisamos saber a data da revista:

$$
\text { - } \quad \text { Mês de Janeiro de } 2009
$$

Depois, precisamos saber quando ocorreu a entrevista. Como não há especificação, podemos imaginar que as afirmações dêiticas da reportagem valem para a data da revista:

- Mês de Janeiro de 2009

Depois existem os espaços mentais responsáveis pelo texto em si. 
- $\quad$ Espaços Mentais referentes ao texto ${ }^{35}$

É importante saber quais são os espaços mentais, além daqueles que compõem estritamente o texto. Se analisamos a oração "os críticos prevêem uma segunda indicação ao Oscar para Angelina” sem nos lembrarmos que a reportagem é de Janeiro de 2009, a oração dita hoje será temporalmente incoerente, pois uma previsão à segunda indicação ao Oscar para Angelina Jolie não pode mais ser dita como futura, mas, sim, como passada, se o leitor desta reportagem a ler hoje, uma vez que a escolha do Oscar de 2009 é passada em relação à data de publicação desta Dissertação.

Os espaços mentais ficariam assim:

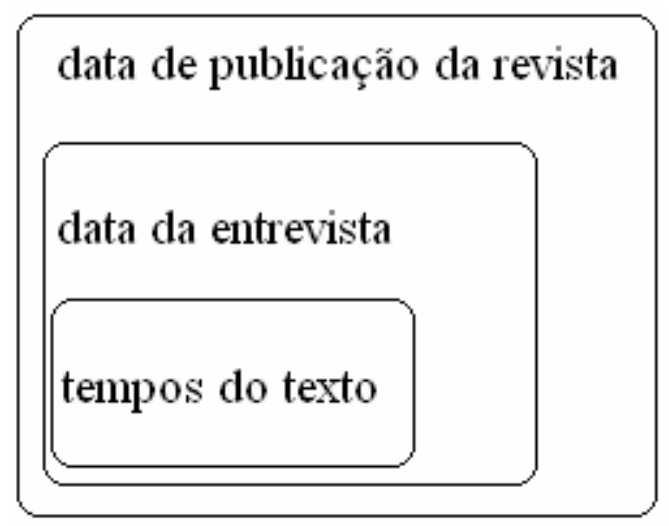

Figura 32 - A composição dos espaços mentais do mais abrangente ao mais específico

Essa teoria ajuda a agrupar os tempos até que cheguemos ao tempo de referência extralinguística, "visualizando" melhor os diferentes cálculos temporais que um discurso necessita para que possamos compreendê-lo.

O homem é um ser dotado de linguagem. Ao agir na e pela língua, ele age num tempo e num espaço que não podem ser desconsiderados. O discurso é um ato e o ato implica tempo. O tempo do mundo, portanto, está pressuposto no tempo da língua. O problema é que a maioria dos estudos do tempo toma para si, durante a interpretação, o momento da enunciação do acontecimento discursivo, e, com isso, não precisamos saber a que hora exata foi proferido o enunciado-ocorrência ${ }^{36}$.

De fato, normalmente não precisamos saber a hora exata em que um enunciado foi proferido. Os romances, por exemplo, podem ser lidos e relidos justamente porque não são

\footnotetext{
${ }^{35}$ Em outra parte deste trabalho, voltaremos a analisar este texto. Então, os Espaços Mentais referentes ao texto serão explicitados.

${ }^{36}$ Enunciado-tipo e enunciado-ocorrência (MAINGUENEAU, 1981 apud FIORIN, 2008) são termos que serão retomados mais adiante.
} 
escravizados pelo momento em que foram escritos. $\mathrm{O}$ tempo da língua não toma para si o tempo do mundo, este será necessário dependendo da referência que o falante quer obter de um texto.

Um estudo como o nosso não deixou de explicitar essa pressuposição entre tempo do mundo e tempo da língua, pois acreditamos que a organização conceitual do tempo parte de um tempo extralinguístico.

\section{6 - A produção e recepção de um enunciado}

Para entendermos que o presente pressuposto da enunciação não está isento das questões do tempo real pelos produtores reais de discursos, imaginemos a situação: um moço gostaria de escrever uma carta para sua namorada, mas sabe que, devido à distância entre eles, esta carta chegará com um dia de atraso, ou seja, não chegará no mesmo dia em que a postar. O remetente (o namorado) terá duas opções para marcar o momento em que escreve a carta:

Quadro 3. Duas opções de carta

\begin{tabular}{|l|l|}
\hline Opção de carta número 1 (não-dêitica) & Opção de carta número 2 (dêitica) \\
\hline $\begin{array}{l}\text { No dia em que escrevia esta carta estava } \\
\text { com muitas saudades suas. }\end{array}$ & Hoje estou com muitas saudades \\
suas.
\end{tabular}

O remetente poderá encontrar formas diferentes de justificar a escolha de uma das duas opções acima:

a) Escolheria a opção 2, pois escreve para dar caráter de verdade no dia em que escreveu e aproveita o fato de que quando sua namorada ler a carta, também estará recebendo mais um dia do conhecimento dessa saudade, pois a carta deverá "valer" para aquele dia também;

b) Escolheria a opção 1, pois, percebendo que sua carta não chegará "hoje”, não quer que a namorada interprete que ele esteja mentindo, reforçando a veracidade da mensagem;

c) Escolheria a opção 2 simplesmente porque escreve no dia do hoje e seu hoje é um hoje; 
d) Escolheria a opção 1, porque não tem certeza se estará sentindo saudades no dia em que a carta chegar.

Há um cálculo temporal a se fazer nesses casos em que se leva em conta como se quer a relação entre o tempo presente da enunciação pressuposta no ato da produção e o tempo da enunciação enunciada: se se deseja que aquela seja coincidente ou não com o tempo da enunciação enunciada. Quando se redige um jornal diário, não se escreve no dia da confecção do jornal (o dia anterior ao seu lançamento) o termo amanhã em uma reportagem que será lançada no dia seguinte, mas escreve-se hoje. Este cálculo terá como efeito - neste caso particular de um jornal - concordar temporalmente o presente pressuposto pelo eu que lerá o jornal com o presente denotado pela enunciação enunciada.

Outras questões pragmáticas de situação comunicativa podem ser resolvidas com marcações de tempo do relógio como, por exemplo, o meio de comunicação em rede Messenger (MSN), que, embora seja considerado simultâneo, pode, às vezes, a "recepção" não ser simultânea à "produção". Neste caso, as precisões de data e hora oferecidas por esse meio podem desfazer equívocos:

Quadro 4. Conversa pelo MSN

\begin{tabular}{|l|}
\hline \multicolumn{1}{|c|}{ MSN } \\
\hline (3h30) João online diz: Vou sair daqui 3 minutos. \\
(3h34) Paula online diz: Então, tá. Nos vemos amanhã? \\
(3h35) Paula online diz: Alô.... você não vai me responder? \\
(3h35) Paula online diz: ? \\
(3h35) Paula online diz: Ah, desculpa, não vi que vc tinha escrito faz tempo. \\
\hline
\end{tabular}

Consideramos importante que um esquema temporal demonstre essas questões do tempo da produção, para podermos ver concatenados, em uma relação lógica com o tempo real, as várias atualizações do tempo linguístico. Não são muito comuns estudos sobre o tempo que se preocupam com as "datas" do momento em que o discurso é enunciado.

Vejamos outro exemplo em que é necessário saber o momento em que foi proferido um enunciado. Imaginemos a seguinte situação. Um consumidor recebe um telefonema dizendo:

(21) Aqui é das Lojas Casa Grande...(interferência na ligação) ...o senhor comprou um item, levou outro igual! 
Sem pedir ao telefonista que repita toda a conversa, recuperando o contexto, o consumidor precisa saber se o enunciado o senhor comprou um item, levou outro igual! tem uma enunciação pressuposta de um presente implícito ou se esse enunciado possui um sistema de enunciação enunciada projetado em um futuro. No primeiro caso, a Loja constata ao cliente que ele fez duas ações: comprou um item e levou outro igual. No segundo caso, a Loja apenas está informando ao cliente sobre uma promoção: "se você comprar um item, ganhará outro igual”.

Vamos tentar esquematizar esse tipo de situação utilizando duas linhas do tempo:

- O passado, o presente e o futuro, enquanto noções do mundo (Time), podem ficar dispostos linearmente e necessariamente nessa ordem. A representação seria:

(1)

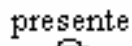

fitiluta

passado

presente.

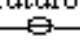

Figura 33 - Linha do tempo cronológica

- O passado, o presente e o futuro, enquanto noções da língua, podem também ficar dispostos linearmente nessa ordem:

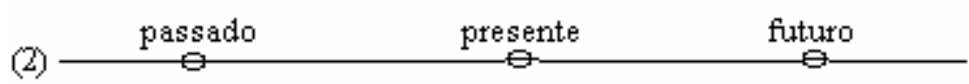

Figura 34 - Linha do tempo gramatical

Vamos analisar o enunciado (3) Quebrou, pagou! visto anteriormente. Esse tipo de enunciado é comum, como podemos perceber em uma "tirinha" do O Estado de São Paulo ${ }^{37}$ :

\footnotetext{
${ }^{37}$ A charge é de 6 de setembro de 2004, e pode ser vista, também, em KOCH; ELIAS, 2006, p.22.
} 


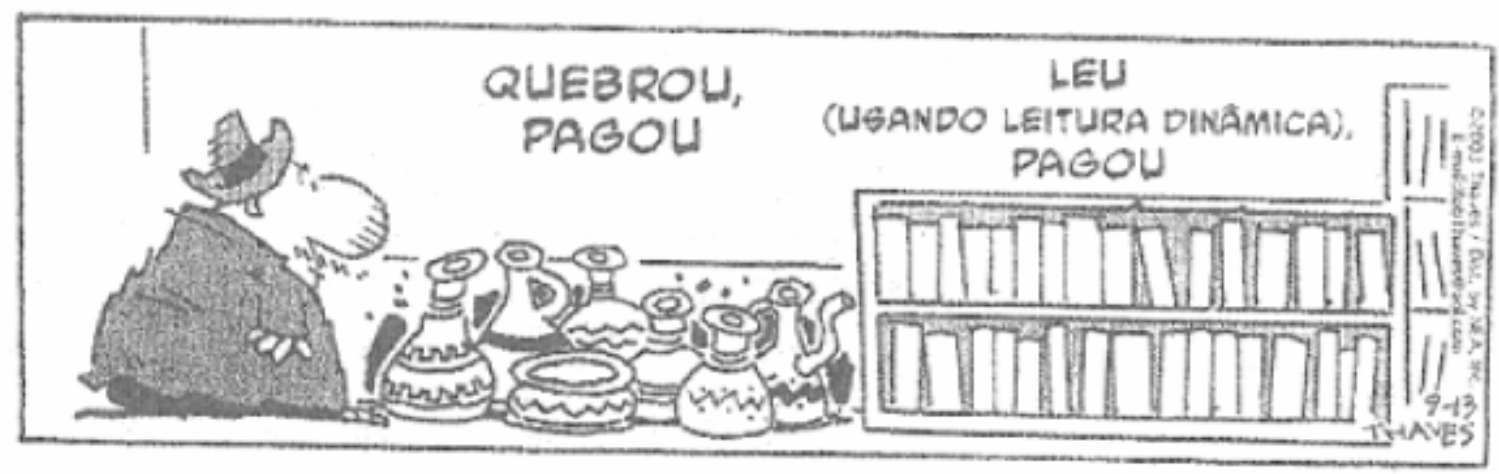

Figura 35 - Charge “Quebrou, pagou”.

(22) Quebrou, pagou!

O enunciado (22), em um primeiro momento, sem a explicitação de um contexto, pode ser proferido em duas situações:

Situação (A), quando se profere o enunciado (22) depois que algo foi quebrado:

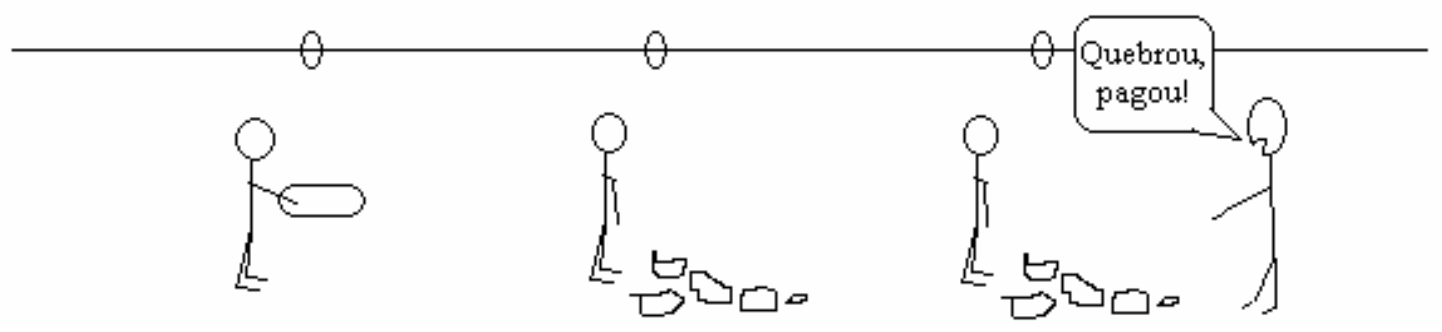

Figura 36 - Imagem cronológica (A)

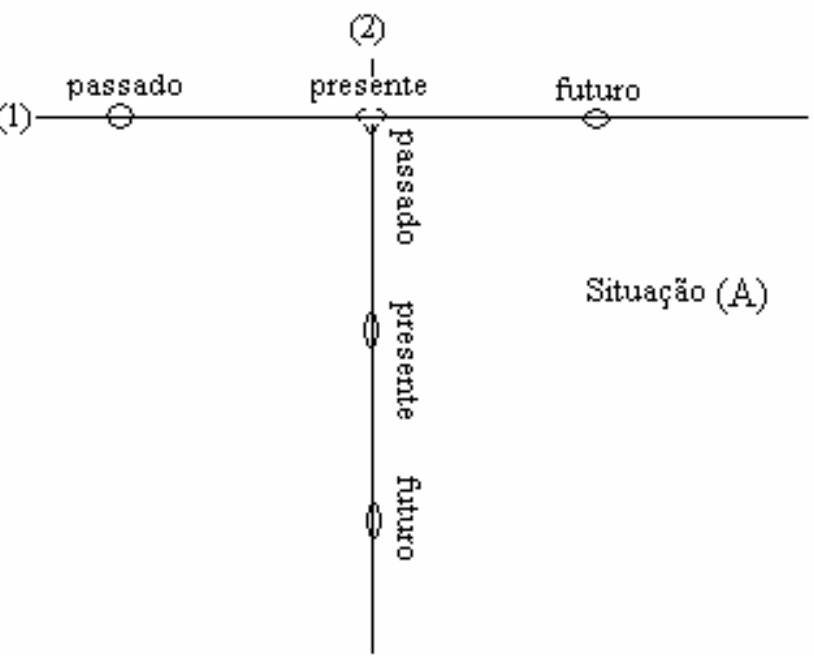

Figura 37 - Intersecção do tempo gramatical e cronológico (A) 
Situação (B), quando se profere o enunciado (3) antes de algo ser quebrado:

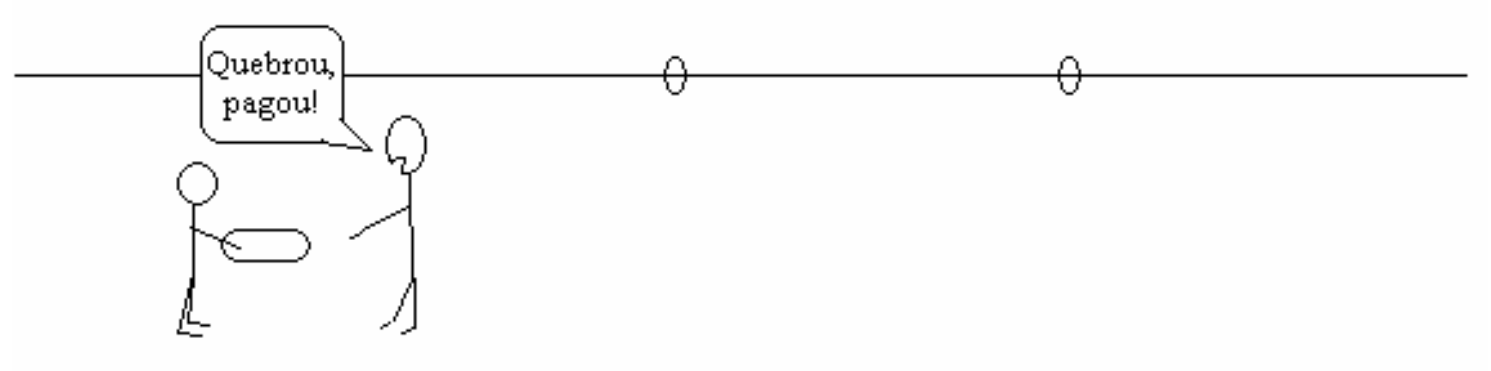

Figura 38 - Imagem cronológica (B)

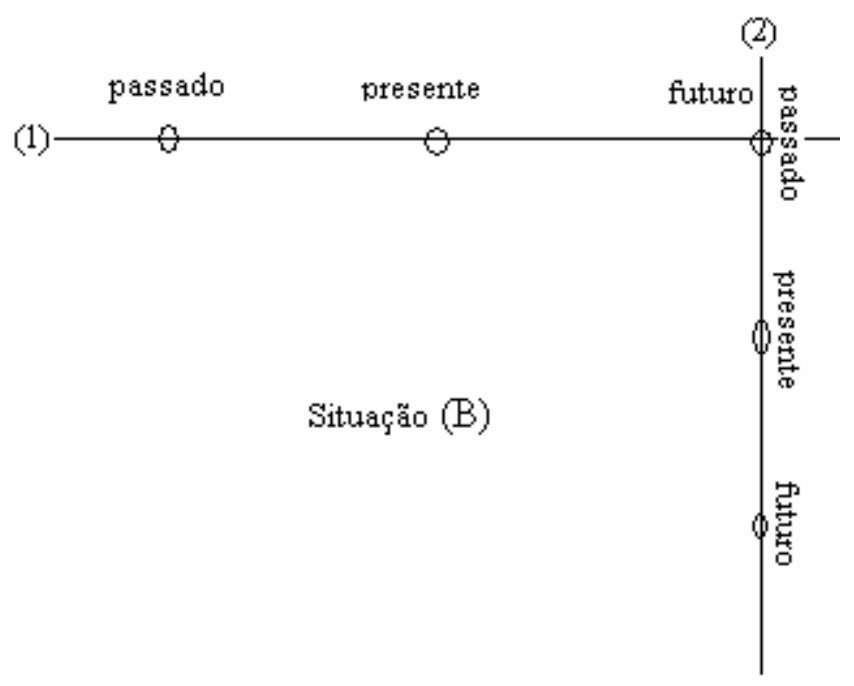

Figura 39 - Intersecção do tempo gramatical e cronológico (B)

Poderíamos também pensar em uma situação (C), em que se diz Quebrou, pagou num momento mais posterior ainda ao contexto descrito em (A). Por exemplo, o cliente quebra um item da loja, paga pelo item e, antes de sair da loja, o dono explica: Na minha loja é assim: quebrou, pagou!. Identificamos o enunciado "quebrou, pagou" neste caso, como sendo equivalente à situação (B), uma vez que o dono da loja não estaria mais se referindo ao item quebrado, mas a uma "regra" geral do seu estabelecimento comercial.

A intersecção entre as linhas do tempo (1) e (2) é onde se encontra o enunciado (22), ou seja, entre a cronologia e a gramática.

É preciso fazer esquemas mais complexos do tempo da língua que levem em conta, de alguma forma, a linha cronológica do tempo. No exemplo da situação (B), podemos interpretar que o enunciador de (22) avisa que a loja não se responsabiliza por objetos 
quebrados pelo consumidor; isso significa que há algum item que pode quebrar, e que quando o consumidor entra na loja, deve saber que há regras, se a pessoa quebrar ela vai pagar.

O enunciado Quebrou, pagou! pode significar Se você quebrar, você pagará! (Situação B), e pode significar Já que quebrou, pague! (Situação A). O sentido será marcado pelo contexto. Mas estamos esquecendo que o verbo pagar do enunciado em questão aparece na forma de pretérito perfeito. Isso significa, quanto à situação (A), que se diz quebrou para algo já quebrado, mas pagou para algo ainda não pago. Um enunciado que não traria essas questões novas de interpretação seria Quebrou, pague!, porque o imperativo do verbo pagar não supõe uma certeza quanto ao ato de pagar. Tudo depende de um contexto pragmático.

Como pudemos perceber, para que a enunciação pressuposta não apresente problemas na compreensão da enunciação enunciada, que se faz com um presente sempre implícito, é necessário saber, num primeiro momento, alguma informação sobre o enunciado-ocorrência, pois podemos precisar fazer alguns cálculos temporais, dependendo da necessidade temporal de se construir ou compreender um enunciado.

Há uma diferença entre momento da fala e o momento em que o discurso é enunciado. O seguinte enunciado, de modalidade escrita:

(23) A próxima Olimpíada será em Londres.

possui o momento da fala dêitico (pode corresponder ao agora de quem lê), mas o momento em que esse discurso foi enunciado, de um ponto de vista de uma enunciação relativa à situação comunicativa, corresponde à data de publicação desta Dissertação, uma vez que não disponibilizamos outra marca cronológica no exemplo (23).

O enunciado escrito:

(24) A Seleção Brasileira de Futebol é campeã mundial na Suécia.

não possui uma marcação cronológica do mundo, portanto, o que nos resta é interpretá-lo como temporalmente dêitico. Isso significa que o referencial natural dessa frase deve coincidir com o momento da fala (o hoje de quem lê). Mas sabemos, pelo nosso conhecimento de mundo, que se essa frase, lida hoje, não for contextualizada, não poderá ser enunciada desse modo hoje, pois sabemos que ultimamente não está acontecendo nenhum campeonato mundial de futebol e muito menos na Suécia. Um leitor descontextualizado se sente imediatamente desconfortável ao ler esse enunciado porque ele percebe que o sistema de referência temporal 
criado pelo enunciado sem um contexto não corresponde a uma verdade temporal interpretável. A contextualização poderia se dar, por exemplo, pelas seguistes formas:

1) informa-se, por exemplo, que esse enunciado pertence a uma pessoa que o escreveu no ano de 1958, como se relêssemos uma manchete de jornal daquela data; ou

2) informa-se que esse enunciado é precedido por um outro do tipo:

(25) Vamos hoje nos lembrar do que ocorreu em 1958. Nessa época, a Seleção Brasileira de Futebol é campeã mundial na Suécia.

Assim o leitor entenderá onde deve formar um sistema referencial: no ano de 1958 e não no ano em que ele se encontra lendo estes enunciados. A segunda forma de contextualizar o enunciado (20) transforma-o no que a tradição gramatical chama de presente histórico, porque a sua forma gramatical de presente só consegue uma interpretação verdadeira se houver uma referência cronológica anterior para instalar mentalmente a referência temporal em que o enunciado deve ser entendido. 


\section{Capítulo 4 - O TEMPO DO DISCURSO}

\section{1 - A teoria de Reichenbach}

Embora não sejam os verbos as únicas formas linguísticas que manifestam a noção de tempo - pois os advérbios, as conjunções, os numerais, os adjetivos, os substantivos, as preposições, por exemplo, também podem trazer informações temporais ${ }^{38}$ - eles são considerados, tradicionalmente, como os elementos que mais de imediato situam o falante no tempo. Os verbos não possuem apenas o 'tempo verbal' como expressão morfológica da temporalidade, pois, além deste, há o modo e o aspecto como elementos do campo verbal que expressam a temporalidade. Eles permitem esclarecer, entre outras coisas, o ponto de vista e a atitude comunicativa assumida pelo enunciador com relação à forma que ele elege para representar o conteúdo do seu discurso. Entretanto, nossa investigação se ateve à noção de tempo nos verbos e à noção de localização temporal que trazem alguns advérbios e marcações cronológicas.

Os verbos conjugados são capazes de possibilitar que o falante localize a ação expressa pelo radical no tempo cronológico, ou seja, no tempo real, por meio dos seus morfemas temporais. Mas a relação entre tempo gramatical e tempo cronológico não é direta, pois precisa passar por uma outra ideia, a de Momento de Referência - inspirada no construto MR (Momento de Referência) de Reichenbach (1966) - que representaremos como uma linha do tempo particular, construída cognitivamente de acordo com a intenção do falante. A construção de MRs seria uma forma de se explicar a criação de uma rede de referenciação em que operamos o tempo todo, através de um processo de recursividade, característico do órgão da linguagem.

De modo geral, as gramáticas apresentam, na forma de interpretar e explicar essas noções, uma relação direta entre os tempos verbais e o tempo real (cronológico). Para Cunha, “[...] verbo é a palavra que exprime um fato (ação, estado ou fenômeno) representado no tempo [...]" (CUNHA, 1970, p.253), mas o gramático não especifica que esse tempo é o tempo da língua, ou, que é um tempo de natureza enunciativa.

Vejamos se essa representação poderia ser direta. Imaginemos o seguinte enunciado:

\section{(26) Ana caiu da escada.}

\footnotetext{
${ }^{38}$ Como podemos ver nos trabalhos de Ilari (2001), Silva (2002), entre outros.
} 
De acordo com as gramáticas tradicionais, o tempo verbal encontrado na frase acima é o pretérito perfeito. Se quisermos defender a ideia das gramáticas de que o tempo verbal reflete diretamente o tempo real, a ação real também terá que ser um "pretérito perfeito", ou seja, um fato ocorrido anteriormente ao momento em que o enunciado foi dito. A compatibilidade é confirmada neste caso (26), pois podemos afirmar que, em algum momento anterior ao "agora" real, Ana caiu da escada.

Se pensarmos em uma linha do tempo, que se dirige da esquerda para a direita no sentido do passado para o futuro, podemos entender o tempo gramatical operando com dois mecanismos: o momento da fala e o momento expressado gramaticalmente. Quando o momento gramatical é passado, ele se encontra anterior ao momento da fala. Quando é concomitante, ele se encontra no mesmo ponto da linha do tempo, juntamente com o momento da fala. Quando o momento gramatical é futuro, ele se encontra posterior ao momento em que se fala.

O exemplo (26) ficaria ilustrado dessa forma:

\section{$\begin{array}{lcc}\text { Tempo cronológico } & \text { passado } & \text { presente futuro } \\ \text { Tempo gramatical } & \text { Ana caiu } & \text { Agora eu digo que }\end{array}$}

Figura 40 - Linha do tempo cronológica e gramatical

Entretanto, se utilizarmos nosso exemplo (26) dentro de um enunciado maior e mais complexo, como o exemplo (27) a seguir, as questões relativas ao tempo também começarão a ganhar mais complexidade:

(27) Vamos fingir que amanhã a Aninha sofrerá um acidente. Diremos à professora que Ana caiu da escada.

A análise do exemplo (27) será, num primeiro momento, propositalmente "linear", justamente para mostramos que uma análise linguística nesse sentido não é possível.

O tempo linguístico expressado pelo verbo cair ainda está, neste exemplo (27), na forma de pretérito perfeito. Entretanto, o tempo real de cair, nesse contexto ficcional, não é um passado, mas um futuro, pois ao lermos o exemplo, interpretamos que no momento em que se lê o enunciado, ou seja, em um momento agora, a menina Ana não caiu da escada, mas cairá amanhã - mesmo em se tratando de um enunciado que é uma suposição (trata-se de uma 
mentira) -, ou seja, a ação de cair para nós se situa num tempo cronológico posterior ao agora e não anterior.

Temos, então, uma ação de tempo passado na língua, mas não temos uma ação de tempo passado no mundo real. Embora a noção de tempo gramatical não seja sempre diretamente representada no tempo real, conseguimos interpretar facilmente o enunciado. Por causa dessa contradição, poderíamos pensar que as gramáticas não dão conta de classificar o tempo verbal de forma a haver sempre um reflexo direto de todas as possibilidades de interpretação do tempo expressado pelo verbo em relação à ação no mundo real.

Isto acontece porque o tempo gramatical (tense) não se liga diretamente ao tempo do mundo cronológico (time). "Weinrich (1971) declara que a 'sinalização verbal' não tem nada a ver com o tempo, mas com a dependência do verbo para com o sujeito falante" (CORÔA, 1985, p.18). Devemos fazer a distinção, portanto, de duas linhas do tempo, a cronológica e a gramatical:

\begin{tabular}{lccc} 
Tempo cronológico & passado & presente & futuro \\
\hline Tempo gramatical & passado & presente & futuro \\
\hline
\end{tabular}

Figura 41 - Linha do tempo cronológica e linha do tempo gramatical

A linha cronológica do tempo não pode ser medida, e não pode ser diretamente relacionada com a estrutura sintática da língua, porque essa linha representa o tempo real unidimensional. Neste momento, percebemos que há a necessidade de um momento que possa relacionar o tempo cronológico com o tempo gramatical, uma vez que agora eles não estão mais sendo entendidos de forma direta, pois estão separados em duas linhas (figura 41).

Reichenbach $^{39}$ (1966), em seu livro Elements of Simbolic Logic, de 1947, consegue explicar como o tempo cronológico se relaciona ao tempo gramatical, apresentando um modelo lógico-descritivo que opera com três construtos fundamentais: $\mathrm{E}$ (event time), $\mathrm{R}$ (reference time) e S (speech time) que, no Brasil, os estudos de linha reichenbachiana traduziram por, respectivamente, ME (momento do evento), MR (momento de referência) e MF (momento da fala).

A tradição brasileira dos estudos reichenbachianos traduziu os construtos de Reichenbach por momentos, mas momento é um termo que pode, por um lado, trazer uma

\footnotetext{
${ }^{39}$ Hans Reichenbach foi um estudioso de línguas estrangeiras, filósofo e lógico, amigo de Einstein e admirador de sua Teoria da Relatividade.
} 
ideia de duração, de intervalo de tempo, de períodos concretos de tempo. Não podemos pensar em "momentos" nesse sentido. Pensamos speech, reference e event em momentos como o lugar (momento) temporal que responde a pergunta quando? ou em que momento?, ou ainda antes, durante ou depois?, uma vez que trabalhar em uma linha cronológica e gramatical do tempo requer sempre, primeiramente, o momento de se verificar quando.

O trabalho pioneiro de Reichenbach (1966) foi usado por vários linguístas e suas ideias aparecem através dos trabalhos deles. Redescobrem e começam a trabalhar com a proposta de Reichenbach na década de 70 do século passado.

Sobre as representações formais do seu modelo, sabemos que:

a) quando um fato ocorre linguisticamente no mesmo momento em que é enunciado um tempo verbal no presente -, temos o ME e MF ocorrendo simultaneamente. Essa simultaneidade em Reichenbach é marcada por vírgulas (,), exemplo: ME, MF;

b) quando o tempo verbal representa uma relação de anterioridade ou precedência ao MF, é marcado com traços (-) de acordo com a linearidade da fala; um caso típico é a ocorrência do pretérito mais-que-perfeito, que precede o pretérito perfeito (que funciona como referência ao verbo que está no pretérito mais-que-perfeito, ou seja, é o seu MR), que, por sua vez, precede o momento da fala, ex.: Eu já tinha lavado a louça quando Pedro chegou: ME $\mathrm{MR}-\mathrm{MF}$;

c) quando a sentença verbal expressa um momento extended, ou seja, um momento progressivo - aspecto contínuo - ou durativo, Reichenbach usou um sistema de retas paralelas sobre uma linha que representa o tempo. Por exemplo:

(28) Eu estou vendo João. (I'm seeing John.)

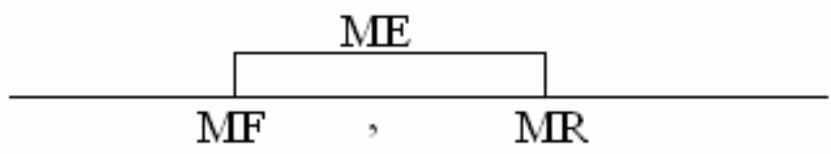

Figura 42 - Aspecto contínuo em Reichenbach

Nesta figura, percebe-se que MF e MR não estão separados no tempo, mas estão ligados por uma vírgula.

A seguir, descrevemos como os tempos verbais de forma simples do indicativo são comumente analisados, utilizando os três construtos de Reichenbach aplicados para o português (CORÔA, 1985, 1998, p.49): 
Quadro 5. As fórmulas de Reichenbach

\begin{tabular}{|c|c|c|}
\hline Base & 13 Possibilidades & Português Brasileiro \\
\hline \multirow{5}{*}{$\begin{array}{l}\text { Passado } \\
\text { ME - MF }\end{array}$} & $\mathrm{ME}-\mathrm{MR}-\mathrm{MF}$ & Pretérito mais-que-perfeito \\
\hline & $\mathrm{MR}-\mathrm{ME}-\mathrm{MF}$ & \\
\hline & ME, MR - MF & Pretérito imperfeito \\
\hline & $\mathrm{ME}-\mathrm{MR}, \mathrm{MF}$ & Pretérito perfeito \\
\hline & $\mathrm{ME}-\mathrm{MF}-\mathrm{MR}$ & \\
\hline \multirow{3}{*}{$\begin{array}{l}\text { Presente } \\
\text { ME, MF }\end{array}$} & ME, MF, MR & Presente \\
\hline & $\mathrm{MR}-\mathrm{ME}, \mathrm{MF}$ & \\
\hline & $\mathrm{ME}, \mathrm{MF}-\mathrm{MR}$ & \\
\hline \multirow{5}{*}{$\begin{array}{c}\text { Futuro } \\
\mathrm{MF}-\mathrm{ME}\end{array}$} & $\mathrm{MF}-\mathrm{MR}-\mathrm{ME}$ & \\
\hline & $\mathrm{MR}-\mathrm{MF}-\mathrm{ME}$ & Futuro do pretérito \\
\hline & $\mathrm{MR}, \mathrm{MF}-\mathrm{ME}$ & Futuro do presente \\
\hline & $\mathrm{MF}-\mathrm{ME}, \mathrm{MR}$ & \\
\hline & $\mathrm{MF}-\mathrm{ME}-\mathrm{MR}$ & \\
\hline
\end{tabular}

Reichenbach prevê, com os três construtos, treze possibilidades formais. Entretanto, as línguas tomarão apenas algumas dessas possibilidades como realizáveis. Afirma Corôa que

[...] a ocorrência da totalidade de combinações matematicamente possíveis entre eles [os três construtos] nunca foi constatada em uma língua natural. Talvez porque nenhum sistema lingüístico dela necessite... De todas as possibilidades, uma língua natural "escolhe" aquele conjunto de relações que considera pertinentes. (CORÔA, 1998, p.38).

A linguista nos demonstra que, em língua portuguesa, utilizamos seis dos treze construtos para descrever os tempos simples do indicativo.

Se representarmos o exemplo (26) Ana caiu da escada, que utilizamos anteriormente, em uma linha do tempo, e utilizarmos a abordagem de Reichenbach, teremos:

caiu $=$ pretérito perfeito $=\mathrm{ME}-\mathrm{MF}, \mathrm{MR}$

$\mathrm{M}$
cail

Figura 43 - Pretérito perfeito em Reichenbach 
Agora, em um exemplo mais complexo, passaremos a traçar esquemas mais complexos:

(29) Vamos fingir que amanhã a Aninha sofrerá um acidente. Diremos à professora que Ana caiu da escada ${ }^{40}$.

Esquematizaremos os quatro verbos que aparecem em (29). Entretanto, devemos perceber que os verbos fingir e dizer, por serem transitivos diretos, pedem um complemento nominal, e por isso, os seus complementos que amanhã a Aninha sofrerá um acidente e Ana caiu da escada, embora sejam sintaticamente considerados sintagmas nominais, de um ponto de vista semântico esses complementos nominais representam ações, "sofrerá" e "caiu", que devem, neste nosso trabalho, trazer sua sistematização na linha do tempo. Esses complementos trazem um conteúdo temporal forte o suficiente para não serem interpretados por um "isto" (que complementaria a regência dos verbos em questão). Os sintagmas nominais são frases simples "Amanhã a Aninha sofrerá um acidente" e "Ana caiu da escada" que, observadas temporalmente como duas pequenas "cenas", nos direcionam a imaginar seus atos (pessoa), palco (espaço), e tempo (ação). Portanto, teremos quatro Momentos de Evento (ME) dispostos em relação a um Momento de Fala (MF):

ME 1- Vamos fingir

ME 2- Sofrerá

ME 3- Diremos

ME 4- Caiu

\begin{tabular}{cccc}
$?$ & & & \\
\hline ME-4 & MF & ME-1,2 & ME-3
\end{tabular}

Figura 44 - Localização de MEs em um único MF

Onde colocaríamos a frase caiu da escada na linha do tempo? Apesar de o verbo cair apresentar o morfema do pretérito perfeito, ele está situado no tempo futuro com relação à cronologia dos fatos, e, portanto, posterior a MF que se relaciona ao momento inicial da enunciação. Não poderíamos colocar caiu (ME-4) na posição indicada por um sinal de interrogação (?) descrito na figura 44 a cima, antes de MF, porque o acidente que Ana sofrerá de mentira não será no momento agora, nem no passado do agora, mas no amanhã, que é

\footnotetext{
${ }^{40} \mathrm{O}$ exemplo 29 é o mesmo exemplo 27.
} 
posterior a MF. O ME-4 será dito em outro momento da fala (MF) em que haverá um novo MF, e, portanto, não ficará mais localizado antes do MF inicial do enunciado, mas terá que migrar e aparecer após ME-2 e antes de ME-3. O fato de haver um novo MF se relaciona com o fato de a língua possuir um centro gerador e axial que se desloca, como veremos mais adiante, assim como veremos também qual a relação entre o construto MF e o momento da enunciação.

Para entender corretamente o enunciado (29), será preciso dividi-lo em duas partes distintas, pois o ME-4 pertence a uma segunda parte, na qual a cronologia temporal foi restabelecida. Nesse sentido, o verbo diremos (ME-3) irá estabelecer um novo referencial temporal para um outro ato de fala (act of speaking), que será um MF-2, e o ME-4 ocupará uma localização anterior, típica de um verbo no tempo pretérito perfeito. Há um transporte de uma linha temporal para outra em que levamos todos nossos conhecimentos anteriores, um transporte indicado por Momentos de Fala - MFs. Deste modo, no nosso exemplo (29), além da linha do Tempo (LT1) da enunciação de MF-1, teremos MF2 e sua linha LT2:

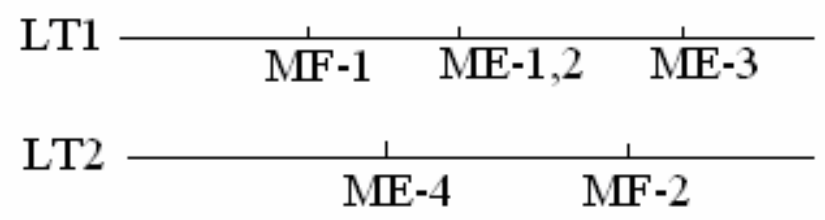

Figura 45 - Localização dos MEs em dois MFs

Agora, o ME-4 pode ficar anterior ao MF-2 porque este está situado no futuro (amanhã) e, com a localização de MF-2, o verbo caiu foi transportado para o futuro, porém localizado antes do MF-2 (verbo dizer).

Exemplos do tipo (29) mostram que é preciso estabelecer corretamente os MFs dos enunciados para, em seguida, localizar os MEs. E, como veremos, quem determina os tipos de coordenadas envolvidas em um MF é o Momento de Referência (MR). Por exemplo, no caso do presente histórico, há normalmente uma locução adverbial de tempo explícita. Esta locução será o MR para o MF. Em uma frase do tipo

(30) Em 1940 eclode a guerra e o soldado vai ao fronte.

o MR está no passado (1940) e por isso o ME eclode passa a se localizar no mesmo sistema inercial do MR. Se o enunciado não tivesse a referência do MR ao passado, 
(31) Eclode a guerra e o soldado vai ao fronte.

haveria coincidência temporal de $\mathrm{MF}, \mathrm{MR}$ e $\mathrm{ME}$, e não se poderia interpretar um presente histórico neste caso.

\section{2 - NÍVEL B) A enunciação}

Ao enunciarmos, podemos deixar marcas, explícitas ou não, da nossa produção no discurso. Por exemplo:

(32) Eu afirmo que a água ferve a $100^{\circ} \mathrm{C}$.

(33) A água ferve a $100^{\circ} \mathrm{C}$.

Em (32), há a explicitação da produção, e devemos perceber que Eu afirmo não é o ato, mas o simulacro do ato de enunciar. Outra possibilidade é produzir um discurso apagando as marcas de produção como em (33). Entretanto, neste caso, mesmo quando os elementos da enunciação não aparecem no enunciado, devemos inferir alguém que o enunciou, uma vez que nenhuma frase se enuncia sozinha. Temos então:

(34) Eu afirmo que a água ferve a $100^{\circ} \mathrm{C}$.

(35) (Alguém afirma que) a água ferve a $100^{\circ} \mathrm{C}$.

Vamos voltar a falar da instância necessária para a comunicação (FIORIN, 1997, p.39), onde devemos, enquanto falantes reais, sempre nos ver enunciando os discursos:

(36) [Eu digo que (Eu afirmo que a água ferve a $100^{\circ} \mathrm{C}$.)]

(37) [Eu digo que \{(Alguém afirma que) a água ferve a $100^{\circ}$ C.\}]

Essa instância pressuposta é sempre presente (digo), e este presente pressuposto corresponde a um presente instantâneo gerador do próprio ato da enunciação. Os exemplos (36) e (37) demonstram que todo enunciado prevê uma instância pressuposta que é sempre um 
presente e que somos sempre nós que mobilizamos a linguagem. $\mathrm{O}$ " [...] tempo tem seu centro - um centro ao mesmo tempo gerador e axial - no presente da instância da fala [...]" (Benveniste, 2006, p.74). A cada nova necessidade de dizer um determinado acontecimento, precisamos enunciar esse acontecimento para presentificá-lo. A enunciação se presentifica instaurando um agora pressuposto a cada instante, ou seja, a cada momento de enunciação; o agora é um "presente [que] é reinventado a cada vez que um homem fala porque é, literalmente, um momento novo, ainda não vivido." (Benveniste, 2006, p.75).

Como o ato de enunciação é da ordem do acontecimento, a enunciação entendida assim, como ato, é impossível de ser estudada pelo linguista. O estudo ou a descrição do ato em si violaria o princípio da imanência que é a base da constituição da Linguística como ciência autônoma. Seu estudo é possível porque o ato de enunciar gera um produto, o enunciado, e nesse enunciado há traços da enunciação.

Fica até mais fácil falar de uma impossibilidade de análise instantânea da enunciação quando se estuda o tempo, porque, dentre as três categorias básicas da enunciação (pessoa, espaço, tempo), o tempo é algo sem ser, um ato individual único feito no presente. "O presente [não tem ser] porque não permanece" (Santo Agostinho, Confissões, 1989, XIV, 17 apud FIORIN, 2008, p.129).

Testar a fugacidade do tempo seria tão impossível quanto escapar desta armadilha:

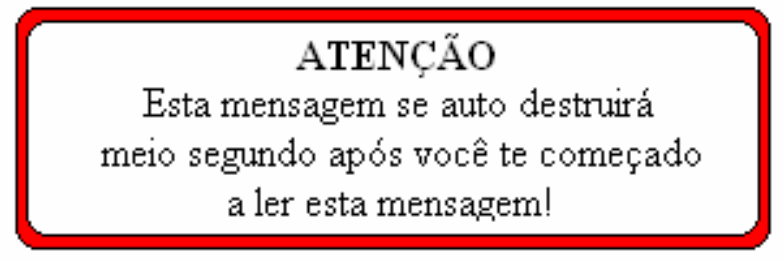

Figura 46 - A armadilha do tempo

É claro que esta figura não passa de uma brincadeira, mas pode ilustrar como o tempo da língua é limitado ao tempo natural.

O eu pressuposto que gera o discurso não é o mesmo eu do enunciador. Ao eu (ou ego) pressuposto, que engendra o discurso, cabe as considerações de uma enunciação extralinguística, enquanto ao sujeito enunciativo, cabe o momento da enunciação que é sempre uma enunciação enunciada. O presente pressuposto é o único elemento da comunicação que possui características do tempo real, porque um discurso para ser compreendido necessita da enunciação que é um fato temporal. 
Uma vez que gostaríamos de descrever uma temporalidade da linguagem e uma temporalidade do discurso, precisamos de dois conceitos de enunciação:

Conforme os pressupostos epistemológicos, implícitos ou explicitados, enunciação se definirá de duas maneiras diferentes: seja como estrutura não-linguística (referencial) que subtende à comunicação linguística, seja como uma instância linguística, logicamente pressuposta pela própria existência do enunciado (que dela contém traços e marcas).

No primeiro caso, falar-se-á de "situação de comunicação", de contexto "psicossociológico" da produção dos enunciados, que tal situação (ou contexto referencial) pode atualizar. No segundo caso, sendo o enunciado considerado o resultado alcançado pela enunciação, esta aparece como a instância de mediação, que assegura a colocação em enunciadodiscurso das virtualidades da língua. De acordo com a primeira acepção, o conceito de enunciação tenderá a aproximar-se do de ato de linguagem, considerado sempre na sua singularidade; de acordo com a segunda, a enunciação é concebida como um componente autônomo da teoria da linguagem, como uma instância que possibilita a passagem entre a competência e a performance (linguísticas); (GREIMAIS; COURTES, 2008, p.166).

A partir dessas considerações, podemos identificar, como já adiantamos, alguns níveis de compreensão do tempo linguístico:

A) o ato em si da linguagem ou o ato da enunciação: falantes reais, situação real e extralinguística de comunicação;

B) instância pressuposta que gera o ato de linguagem (o eu particular, sempre presente) e que instala um Momento zero da Fala (MF);

C) a enunciação enunciada, com seu sistema de referência do tempo (MR);

D) o conteúdo temporal do enunciado.

Para uma temporalidade da linguagem, devemos pensar nos elementos descritos na situação de comunicação, (nível A), e nas questões reais que envolvem aquele que engendra o discurso através de um eu enunciativo pressuposto, (nível B), ou seja, embora o tempo estritamente linguístico se inicie com a questão da instância pressuposta, esta ainda pertence, em termos, a um mundo real, no nível (A).

Quanto à temporalidade do discurso (níveis B, C e D), é necessária também uma abordagem pragmática porque um texto pode apresentar certos fatos linguísticos que só são entendidos analisando as condições pragmáticas que governam a utilização da linguagem. Ao enunciarmos, frequentemente deixamos ou identificamos marcas pragmáticas explicitas ou não no enunciado. Portanto, o enunciado “[...] comporta freqüentemente elementos que remetem à instância de enunciação: pronomes pessoais, demonstrativos, possessivos, adjetivos e advérbios apreciativos, advérbios espaciais e temporais, etc.” (FIORIN, 2003, p.162). No 
que se refere ao tempo, essa exigência é ainda mais compreensível, como se comprova, por exemplo, com os marcadores de tempo dêiticos (hoje, amanhã, ontem):

Um dêitico só pode ser entendido dentro da situação de comunicação e, quando aparece, num texto escrito, a situação enunciativa deve ser explicitada. Se encontrarmos um bilhete em que esteja escrito Ontem trabalhei muito aqui, não entenderemos plenamente a mensagem, pois não saberemos quem trabalhou, quando é ontem e onde é aqui. Em resumo, não se pode saber o sentido do $e u$, do ontem, e do aqui da mensagem pois falta o conhecimento da situação de comunicação. No caso dos dêiticos, não adianta só o conhecimento do sistema lingüístico, pois o que é preciso, para entendê-los, é conhecer a situação de uso. (FIORIN, 2003, p.162).

Podemos pensar que somente os elementos tradicionalmente classificados como dêiticos precisam do conhecimento da situação de uso. Mas há elementos classificados como cronológicos que precisam, dependendo de um contexto, de mais informações cronológicas, se não quiserem ser ambíguos temporalmente. Exemplo:

\section{(38) Em Outubro trabalharei muito aqui.}

Outubro, que é uma marcação cronológica tipicamente referencial por ser um marco cronológico, tradicionalmente não dêitico, se torna um elemento dêitico, se não se especifica a que ano esse mês se refere. Se o bilhete for escrito em Setembro de 2000 e encontrado e lido em Novembro de 2000, o receptor poderá pensar que, sendo um bilhete atual, o próximo Outubro é de 2001. Sua interpretação manterá a ação futura, mas na realidade, a ação é passada para quem escreveu. É por isso que devemos pensar em uma descrição da enunciação que reflita a situação de comunicação real.

Devemos, então, refletir sobre a instância enunciativa, pois todo enunciado é realizado numa situação definida pelos participantes da comunicação (eu/tu), pelo momento da enunciação (agora), e pelo lugar em que o enunciado é produzido (aqui). Normalmente não precisamos saber a data da produção de um enunciado, mas às vezes é necessário: se se encontra um bilhete hoje, no qual está escrito hoje, o nível de se interpretar esse hoje primeiramente se dá em (A), ou seja, no tempo real da produção e recepção.

Por isso, devemos nos lembrar de que, por ser organicamente ligado ao exercício da fala, o tempo é dependente do tempo real, porque o exercício da fala é efetuado no tempo real. Como o enunciado não costuma ser estudado conectado nem anexado com a descrição de seu ato, ele é sempre um enunciado-tipo. Se fosse possível anexar essa referência para efeito de estudo, poderíamos ter um enunciado-ocorrência. Enunciado-tipo é aquele que se considera 
o mesmo enunciado, independentemente das vezes que é enunciado, e o enunciado-ocorrência é o enunciado-tipo cada uma das vezes que é enunciado (FIORIN, 2008, p.54).

Se considerarmos um enunciado que seja um enunciado-tipo, teremos, para análise, sempre as mesmas referências para as categorias da enunciação eu, aqui e agora, porque elas se referem ao enunciado e não mais à situação da comunicação extralinguística. É mais fácil entender essa questão de impossibilidade de "referenciação" utilizando a categoria do tempo do que utilizando a do espaço, por exemplo, que nos parece, em algumas situações, ser sempre o mesmo, independente das vezes que é enunciado. A enunciação é um ato e o ato é uma ação presente, e o presente é uma instância fugidia. A instância da enunciação sempre decide por uma enunciação enunciada nos estudos da temporalidade do discurso.

Não podemos confundir, portando, dois níveis: o nível da enunciação pressuposta (B) e o nível da enunciação enunciada (C).

Não há enunciação enunciada em (33) A água ferve a $100^{\circ} \mathrm{C}$, pois o que há é uma enunciação enunciada implícita: Alguém afirma que.

Há uma enunciação enunciada em (34) Eu afirmo que a água ferve a $100^{\circ} \mathrm{C}$.

Há sempre uma enunciação pressuposta em (33) A água ferve a $100^{\circ} \mathrm{C}$ e (34) Eu afirmo que a água ferve a $100^{\circ} \mathrm{C}$.

Depois das considerações sobre o ato de produção do enunciado, vamos analisar a questão do momento da enunciação enunciada. Como vimos, segundo a Semiótica Francesa, as categorias de tempo (e também de pessoa e de espaço) passam do ato da enunciação para o enunciado através do mecanismo da debreagem temporal. Entretanto, falta-nos falar sobre o mecanismo da embreagem:

Os mecanismos de instalação de pessoas, espaços e tempos no enunciado são dois: a debreagem e a embreagem. Debreagem é a operação em que se projetam no enunciado a pessoa, o espaço e o tempo (Greimas e Courtès, 1979, 79). Há, pois, uma debreagem actancial (= de pessoa), uma debreagem espacial e uma debreagem temporal. (FIORIN, 2003, p.178).

Embreagem é também um mecanismo de instalação do ego, hic et nunc. Entretanto, ao contrário da debreagem que instala no discurso elementos que correspondem à situação de comunicação, a embreagem vai instalar outros elementos, denunciando que a linguagem é um “jogo” semiótico, e não a realidade em si mesma.

Todos esses mecanismos produzem efeitos de sentido no discurso. Não é indiferente o narrador projetar-se no enunciado ou alhear-se dele; simular uma concomitância dos fatos narrados com o momento da enunciação ou apresentá-los como anteriores ou posteriores a ele; presentificar o pretérito; 
enunciar um eu sob a forma de um ele, etc. Com a debreagem parece que a linguagem imita os tempos do mundo, os espaços do mundo e as pessoas do mundo. No entanto, com a embreagem, quando se apresenta uma primeira pessoa como segunda, uma terceira como primeira, um futuro do presente como presente, um futuro do pretérito como um pretérito imperfeito, um lá como aí, etc., mostra-se que pessoas, tempos e espaços são criações da linguagem e não decalque da realidade. E assim esse modo de enunciar vai criando sentidos como aproximação, distanciamento, atenuação, irrealidade, etc. (FIORIN, 2003, p.181).

\subsection{1 - A enunciação pressuposta e o Momento da Fala}

Podemos dizer que o Momento da Fala de Reichenbach (1966) corresponde à noção de Benveniste (2006) de centro gerador do discurso, que se desloca e que corresponde a cada instituição de debreagem. Entretanto, enquanto o momento do ato da enunciação é organicamente ligado ao ato da fala, o Momento da Fala (MF), apesar de se corresponder a ele de forma lógica, compartilha de uma outra natureza: a do discurso. "É evidente que este presente, na medida em que é função do discurso, não pode ser localizado em uma divisão particular do tempo crônico, porque ele admite todas as divisões e não se refere a nenhuma em particular.” (BENVENISTE, 2006, p.75).

O Momento da Fala (MF) é um centro de natureza textual e, por isso, não corresponde temporalmente com o momento do ato de enunciar, que é físico. Isto significa que o MF é apenas um ponto zero referencial ao discurso. Para Reichenbach (1966), o MF é um tempo limitado que o indivíduo possui ao enunciar e no qual estabelecerá o ato de fala. É o momento em que o indivíduo pronunciará suas sentenças verbais que irão apresentar e determinar o tempo do evento em relação às referências temporais dadas pelo MR.

O construto MF também não deve ser confundido com o momento da produção do discurso; o MF não é simplesmente o momento em que foi escrito o enunciado, não é a data do jornal em que foi publicado, nem o ano em que um livro foi lançado. Interpretar o MF como sendo algum dos eventos acima (publicação) é um modo inadequado de definir o momento zero da enunciação enunciada de um discurso ${ }^{41}$. Se essas informações fossem marcas que fizessem referência a um único MF de um dado enunciado, o tempo linguístico teria uma relação direta com o tempo real. Mas, como vimos, essa relação não pode se dar de

\footnotetext{
${ }^{41}$ Algumas vezes, como veremos, essas marcações irão coincidir com o MF, mas este não deve ser confundido com aquelas marcações.
} 
maneira direta. O tempo da linguagem é dêitico e de natureza enunciativa. Cada momento zero da enunciação enunciada (MF) pode, de alguma forma, ser pensado como o momento zero do ato da enunciação, porque aquele é concomitante à este, mas são de naturezas distintas.

Através dos construtos de Reichenbach, podemos dizer que a categoria dêitica do tempo se organiza em língua portuguesa dispondo os eventos futuros posteriormente ao $\mathrm{MF}$, os eventos presentes simultâneos ao MF, e os eventos passados anteriormente ao MF. Por esse motivo o MF não deve ser confundido com o presente axial da linguagem, pois enquanto este presente axial mobiliza um tempo verbal pretérito, por exemplo, o MF está estabelecido posteriormente a esse passado (e não se "deslocando" organicamente sobre essa noção), estabelecendo um ponto zero em relação ao presente desse tempo verbal. Além disso, o MF, diferentemente do presente axial do discurso, pode ser pensado tomando-se a forma de outros tempos verbais, além do presente. Isto porque, de acordo com a nossa interpretação, o ponto zero de referência lógica $(\mathrm{MF})$ de cada sistema referencial (MR) não se refere necessariamente a um presente gramatical.

Vejamos algumas relações possíveis entre ME e MF:

(39) Daqui a pouco fecharei a loja. MF - ME

(40) Esta última cliente está vendo um vaso. MF, ME

(41) Ontem ela comprou um abajur. ME - MF

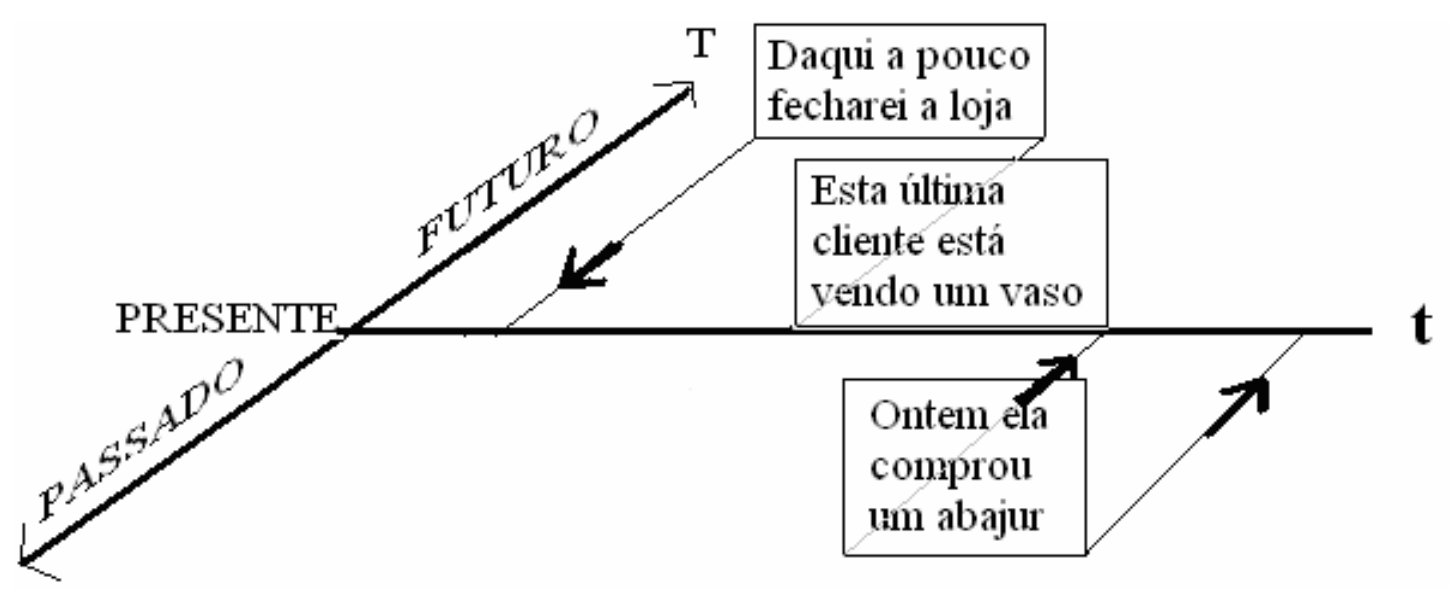

Figura 47 - Os MEs em um eixo MF "distendido"

O esquema utilizado para ilustrar os exemplos (39), (40) e (41) se parece com o esquema da figura 2 que ilustrava o pensamento de Santo Agostinho de que o tempo só 
poderia ser presente. A linha $(\mathrm{T})$ representa o tempo cronológico. $\mathrm{O}$ eixo $(\mathrm{t})$ localizado apenas tocando um ponto do eixo (T) é o ato da enunciação. Ele fica entre um passado e um futuro porque o ato é algo que foge da captação do tempo - o futuro torna-se imediatamente um passado. O eixo (t) representa, como vimos, uma extensão, ou “distensão”, da alma. É nesta "alma" que operamos o tempo linguístico. Ao passo que o enunciador se desloca num tempo real, porque o ato da linguagem é um ato temporal por natureza, a distentio animi (eixo t) permanece sempre presente devido à condição da enunciação. Entretanto, os assuntos tratados pelo conteúdo do enunciado podem refletir o presente, o passado ou o futuro. Estes são projetados pelo eixo $(\mathrm{T})$ para marcar o seu devido lugar cronológico. Como podemos ver na figura 47, os três enunciados escritos dentro de "quadros" estão projetados para trás, sobre ou para frente, mas sem se desprenderem referencialmente do eixo presente ${ }^{42}$. Com isso, devemos dizer que o enunciado (41) é teoricamente passado porque, na verdade, ele está se referindo a algo passado, mas a partir de um eixo presente e não perde ilustrativamente essa referência com o eixo do presente - um "presente do passado", diria Santo Agostinho.

Se interpretarmos a figura 47 de baixo (passado) para cima (futuro), teremos a história sendo contada em uma ordem cronológica dos fatos. Se interpretarmos da esquerda para a direita, teremos a história sendo contada em uma ordem cronológica do ato de enunciar.

Traduzindo-se a figura 47 para uma linguagem reichenbachiana, considerando-se que o ME se organiza em termos de antecedência, precedência e concomitância com o momento da fala, diríamos que os quadros contendo os enunciados seriam os MEs, e o MF sempre fica no eixo dêitico do presente, e se repete, deslocando-se a cada enunciado. Esquematicamente, temos um ME localizado ou à direita (futuro), ou ao centro (presente) ou à esquerda (passado):

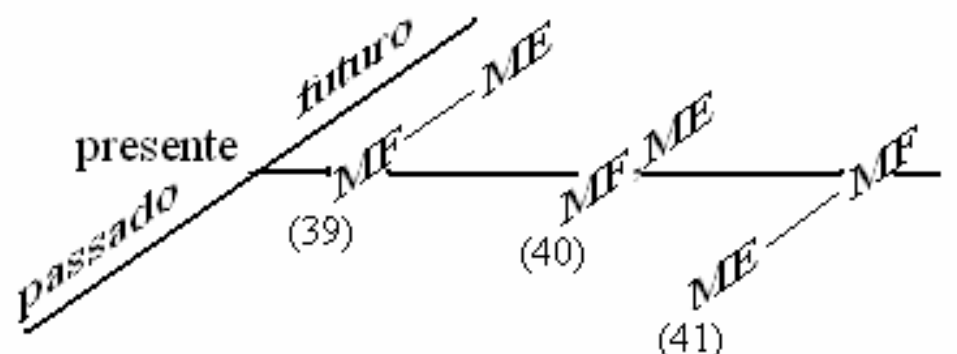

(41)

Figura 48 - Os exemplos (39), (40) e (41) dispostos, em ME e MF, no presente "distendido"

\footnotetext{
${ }^{42}$ Os quadrados que enquadram os enunciados têm suas bases ligadas ao eixo do presente e essa ligação está sinalizada por pequenas flechas (figura 47).
} 
Nesta esquematização, o MF precisou ser reescrito em cada quadro de ME, mas em uma próxima descrição (figura 49), como veremos, isso não será necessário.

A enunciação pressuposta, com o seu centro zero gerador e axial do discurso, faz surgir o enunciado. O Momento da Fala de Reichenbach para nós se orienta como um ponto zero lógico e operatório, concomitante ao presente implícito do ato da enunciação. Além disso, o MF não é mais físico, como é o presente axial do discurso, mas é uma realidade criada pelo discurso de acordo com a intencionalidade do falante. Isso quer dizer que, quando nos apropriamos de um discurso, ou seja, quando enunciamos, tomamos o discurso em sua intencionalidade e como temporalmente o discurso pode se dividir em subjetivo ou objetivo, o nosso MF será ou um ponto zero subjetivo (agora) ou um ponto zero objetivo (então). Por isso, o MF não se confunde com a enunciação pressuposta, embora eles dois elementos se organizem juntamente por se deslocarem ao longo do discurso.

\section{3 - NÍVEL C) A enunciação enunciada em seus MRs}

Entendida a relação entre ME e MF, precisamos nesse momento entender como se dá o MF em relação ao tempo cronológico. Para isso, ao invés de projetarmos os quadros da figura 47 nos seus lugares temporais (presente, passado ou futuro), lembrando que todos eles são projetados a partir de uma "linha do tempo" presente, vamos considerar os enunciados (39), (40) e (41) como sendo um texto único, para não confundirmos as direções de antecedência, precedência e concomitância que o MF também pode fazer em relação ao tempo cronológico. Assim:

(42) Daqui a pouco fecharei a loja. Esta última cliente está vendo um vaso. Ontem ela comprou um abajur. 


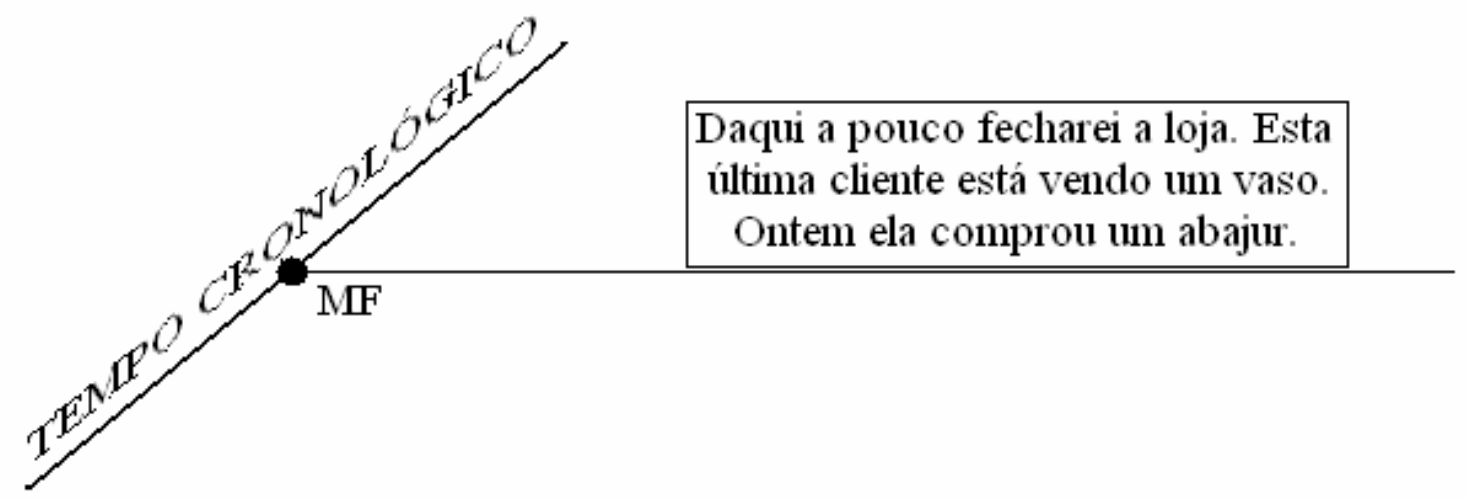

Figura 49 - Localização cronológica do enunciado (42)

$\mathrm{Na}$ figura 47, cada pequeno quadro era um ME. Na figura 49 e 50, queremos mostrar que cada quadro é um conjunto de MFs que compartilham um mesmo eixo discursivo, ou seja, um mesmo MR, afinal, os quadros eram projetados a partir de uma mesma linha ( $\mathrm{t}$ ).

Como o texto apresentado faz parte, por suas características dêiticas, do que Benveniste chama de um texto discursivo ${ }^{43}$, o eixo do MF de (42) pode se localizar num ponto dêitico presente da série cronológica, uma vez que se afirme que o enunciado (42) é da modalidade oral. Vamos imaginar que o falante que profere (42), continua seu discurso proferindo (43):

(43) Eu tinha encontrado um baleiro ontem no mercado, mas tinha esquecido de levar dinheiro e as lojas não aceitavam cartão.

Esse novo texto, por suas características temporais não-dêiticas, seria um texto narrativo, segundo Benveniste, e o eixo ordenador dos MFs de (43) fica cognitivamente projetado em um tempo cronológico anterior ao ponto dêitico do eixo do texto (42), porque se trata de um texto narrativo passado:

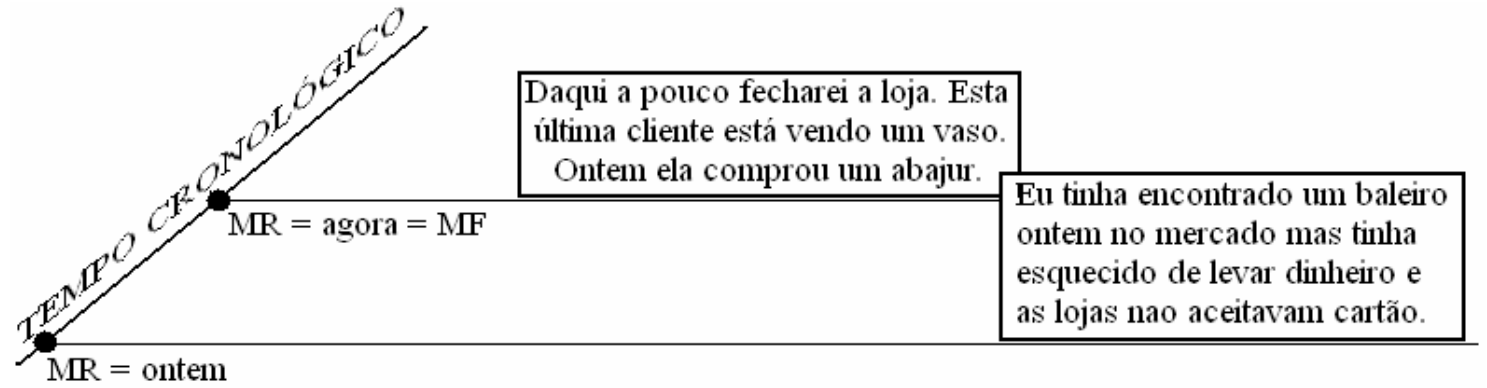

Figura 50 - Localização cronológica do momento de referência (MR)

${ }^{43}$ Veremos melhor essa questão nas próximas seções. 
A "linha" do tempo está ligada ao tempo cronológico por um momento de referência (MR) para que os textos (42) e (43) tenham seu sentido no tempo. Entretanto, os enunciados se situam sempre no presente da fala, que não necessita de uma marcação no tempo, porque é sempre presente; por isso, os enunciados analisados na figura 47 não estão ilustrativamente situados em algum lugar sobre a linha cronológica, mas sobre a linha do momento da fala, identificando-se funcionalmente com o presente da instância da comunicação.

Um texto formado pelo enunciado (42) e o enunciado (43) juntamente, $(42+43)$, é mais complexo temporalmente, pois exige dois sistemas de referência. É o MF que nos coloca o agora, mas o agora só pode ser entendido por nós como relativo - porque é de natureza enunciativa - depois que sabemos identificar onde o eixo enunciativo está projetado em uma linha cronológica. Acreditamos que essa identificação se dê com a determinação dos MRs inspirados em Reichenbach.

\subsection{1 - Sobre a natureza do construto do Momento de Referência (MR)}

Como vimos no capítulo 2, a Teoria da Relatividade Restrita (TRR) de Einstein provou que as relações temporais se dão com respeito a um sistema inerte de referência temporal. Essa questão do plano inercial trouxe não só aplicabilidade para a Física, mas para outras ciências como a Filosofia e a Lógica. Segundo Corôa (1998, p.43), Lacey (1972) e Hornstein (1977) adotaram o sistema de inércia em seus estudos. Para este nosso estudo linguístico, podemos dizer que usar uma teoria que considera um plano inercial é a nossa "licença" para a construção de Momentos de Referência, que se dão em Espaços Mentais para que ocorram os eixos de Momentos de Fala; com isso também mostraremos a importância de uma Teoria Cognitiva.

$\mathrm{Na}$ enunciação, os interlocutores ocupam o mesmo sistema de referência, pois o enunciador deve, pela linguagem, transmitir ao enunciatário quais são as diretrizes para o estabelecimento de um sistema de coordenadas temporais - sistema inercial. Com Einstein, o tempo é definido com respeito a um dado observador. Este observador na Física é o elemento que corresponderia ao MR na linguística (CORÔA, 1998). O sistema de referência inercial é o MR. A partir de um ponto de vista que utilizava os conceitos da Teoria da Relatividade de 
Einstein, Reinchenbach “[...] foi capaz de esclarecer as contradições que na época existiam na ligação entre lógica e língua natural [...]." (CORÔA, 1985, p.27).

Einstein modificou a Física Clássica porque trouxe para nós a relatividade na percepção do evento, tomando-se atenção para que relações entre percepções de eventos não fossem necessariamente iguais às relações temporais entre os eventos. Então, o tempo é mais que dependente de um observador: ele é definido com respeito a um observador. Consequentemente, só se consegue atribuir valor de verdade a uma proposição temporal com respeito a um observador. (CORÔA, 1985, p.30). Podemos perceber como o construto MR é o mais complexo dentre os três construtos de Reichenbach, ou seja, o MF, o MR e o ME:

[...] o MR [é] o mais complexo desses construtos. Sua natureza quase que estritamente teórica faz com que esteja mais afastado do ato de comunicação do que o MF e seus contornos sejam ainda menos concretamente percebidos [...] Ele é o sistema de inércia que serve de referencial fixo para uma definição de tempo [...] O 'ponto de referência' de Reichenbach incorporado aos estudos lingüísticos, é uma conseqüência direta da visão relativa de tempo que passamos a ter depois de Einstein. (CORÔA, 1985, p.40).

O MR é a perspectiva de tempo adotada pelo enunciador e pelo enunciatário sobre o seu MF. Como vimos no exemplo (3) Quebrou, pagou!, um dos usos desse enunciado pode ocorrer mesmo se nada contextualmente tiver sido quebrado. Neste caso, entretanto, o falante que profere (3) possui uma perspectiva de tempo futuro e o seu ouvinte deve compartilhar dessa perspectiva, "instalando-se" nesse mesmo plano inercial futuro.

Essa projeção de perspectiva temporal é muito comum para qualquer falante de uma língua, pois podemos dizer que ela seria o mesmo tipo de transporte psicológico que ocorre no que as gramáticas tradicionais chamam de "discurso direto"44 (DD). Em outras palavras, o sistema inercial que Reichenbach trouxe da Física para a Linguagem demonstra algo que sempre nos foi intuitivamente óbvio. Consideremos o seguinte texto:

(44 a) Era uma vez um lobo que dizia:

b) - Oi, eu sou mal.

Parece muito natural afirmar que no momento em que lemos ou ouvimos o enunciado (44 b) somos transportados para o tempo do dizer do lobo, como se estivéssemos presenciando e vivenciando o momento em que o lobo está, e não mais como se estivéssemos no passado de

\footnotetext{
${ }^{44}$ A reenunciação compõe uma futura subseção.
} 
Era uma vez..., ou seja, no tempo do narrador. Isso porque estamos sempre buscando estar no mesmo plano de referências do enunciado.

\subsection{2 - Os dois grandes sistemas temporais}

Nossa pesquisa sobre o tempo percebeu que o construto do Momento de Referência de Reichenbach precisa necessariamente receber uma interpretação à luz das teorias enunciativas que consideram que a língua possui dois grandes sistemas temporais, porque acreditamos que a enunciação é um ato de narrar acontecimentos ora de forma que estes pertençam a um mundo narrado ora a um mundo comentado. Como consideramos o tempo da linguagem bidirecional, enquanto Reichenbach o considera unidirecional, o construto MR possuirá características novas na nossa proposta.

\subsubsection{1 - A proposta greimasiana da temporalidade do discurso}

Como vimos anteriormente, a Semiótica Francesa considera que a debreagem temporal produz um tempo do agora e um tempo do então. Estes orientam dois sistemas temporais:

[...] existem na língua dois sistemas temporais: um relacionado diretamente ao momento da enunciação e outro ordenado em função de momentos de referência instalados no enunciado. Assim, temos um sistema enunciativo no primeiro caso e um enuncivo no segundo. Ocorre, no entanto, que o momento de referência está relacionado ao momento da enunciação, já que este é o eixo fundamental de ordenação temporal na língua. Por isso, ao momento da enunciação aplicamos a categoria topológica concomitância vs não-concomitância (anterioridade vs posterioridade) e obtemos três momentos de referência: concomitante, anterior e posterior ao momento da enunciação. (FIORIN, 2008, p.145-146). 
A aplicação da topologia ao momento da enunciação, segundo Fiorin, é esquematizada da seguinte forma ${ }^{45}$ :

Quadro 6. Proposta de Fiorin (2008, p.146)

\begin{tabular}{|c|c|c|c|c|c|c|c|c|c|}
\hline ME & \multicolumn{9}{|c|}{ (ME) PRESENTE MMPLÍCITO } \\
\hline \multirow[t]{2}{*}{$\begin{array}{l}\text { Categoria } \\
\text { topológica }\end{array}$} & \multirow{2}{*}{\multicolumn{3}{|c|}{$\begin{array}{l}\text { Concomitância } \\
\text { sistema enunciativo }\end{array}$}} & \multicolumn{6}{|c|}{$\begin{array}{l}\text { Não concomitância } \\
\text { sistema enurcivo }\end{array}$} \\
\hline & & & & & erior & & & osterior & \\
\hline $\begin{array}{l}\text { Momento } \\
\text { de Referência }\end{array}$ & \multicolumn{3}{|c|}{ MR presente } & \multicolumn{3}{|c|}{ MR pretérito } & \multicolumn{3}{|c|}{ MR futuro } \\
\hline \multirow{2}{*}{$\begin{array}{l}\text { Categoria } \\
\text { topológica }\end{array}$} & \multirow{2}{*}{$\begin{array}{l}\text { Concomi } \\
\text { tância }\end{array}$} & \multicolumn{2}{|c|}{ Não concomitância } & \multirow{2}{*}{$\begin{array}{l}\text { Concomi } \\
\text { tância }\end{array}$} & \multicolumn{2}{|c|}{ Não concomitância } & \multirow{2}{*}{$\begin{array}{l}\text { Concomi } \\
\text { tância }\end{array}$} & \multicolumn{2}{|c|}{ Não concomitância } \\
\hline & & anterior & posterior & & anterior & posterior & & anterior & posterior \\
\hline $\begin{array}{l}\text { Momento } \\
\text { dos Aconte } \\
\text { cimentos } \\
\text { (MA) }\end{array}$ & $\underset{\text { presente }}{\text { MA }}$ & $\underset{\text { pretérito }}{\text { MA }}$ & $\begin{array}{l}\text { MA } \\
\text { futuro }\end{array}$ & $\underset{\text { presente }}{\text { MA }}$ & $\begin{array}{c}\text { MA } \\
\text { pretérito }\end{array}$ & $\begin{array}{l}\text { MA } \\
\text { futuro }\end{array}$ & $\begin{array}{c}\text { MA } \\
\text { presente }\end{array}$ & $\begin{array}{c}\text { MA } \\
\text { pretérito }\end{array}$ & $\begin{array}{l}\text { MA } \\
\text { futuro }\end{array}$ \\
\hline
\end{tabular}

Esse quadro 6 foi formulado a partir da sistematização de Fiorin (2008, p.146).

Assim, todos os tempos estão intrinsecamente relacionados à enunciação. Com a categoria da concomitância vs não concomitância (anterioridade vs posterioridade), criam-se três momentos de referência: um presente, um passado e um futuro. O momento de referência presente é um agora, pois ele coincide com o momento da enunciação. $\mathrm{O}$ momento de referência passado indica uma anterioridade ao momento da enunciação; o futuro, uma posterioridade a esse momento. (FIORIN, 2003, p.166).

Aplicando-se a categoria topológica ao Momento da Enunciação, foram gerados três subsistemas: agora, então posterior e então anterior. Para cada subsistema, há três Momentos dos Acontecimentos (MAs), porque é aplicada a categoria topológica a cada MR. Portanto, temos nove MAs.

Nessa temporalidade do discurso, constata-se que o tempo enuncivo é subordinado ao tempo enunciativo. A anterioridade ou a posterioridade de um enunciado, embora organicamente concomitante ao momento presente do ato da enunciação, ganha caráter não concomitante em relação ao momento de enunciação porque se trata de um ponto de vista discursivo; o que é anterior ou posterior a um momento da enunciação é a referência estabelecida pelo conteúdo discursivo de uma enunciação enunciada.

\footnotetext{
${ }^{45}$ Fiorin, em As Astúcias da Enunciação (2008), deduz todas as possibilidades tipológicas de debreagens e de embreagens da enunciação, nos seus três procedimentos básicos: temporalização, espacialização e atorização. Fez, para isso, projeções da enunciação no enunciado e estudou as relações entre enunciador e enunciatário.
} 
A descrição dos dois sistemas temporais explicados pela teoria greimasiana (enunciativo e enuncivo) estão relacionados entre si, pois a categoria topológica de concomitância e não-concomitância é aplicada aos dois, juntamente. Assim, o que é concomitante é presente (tempo igual a zero), o que não é concomitante é diferente de zero (os tempos do então), sendo que o que for maior que zero é uma não concomitância posterior, e o que é menor que zero é uma não concomitância anterior.

\subsubsection{2 - Nossa proposta de descrição dos dois sistemas temporais do discurso a partir da temporalidade da linguagem}

Nessa subseção, discutiremos uma proposta de descrição semântica do tempo utilizando algumas considerações greimasianas sobre o assunto. Devemos admitir que uma discussão desse tipo necessitaria de um maior aprofundamento, porque as ideias de Greimas são bastante complexas e mereceriam um estudo só seu. Optamos por não desenvolver nosso trabalho dentro da perspectiva greimasiana, embora reconheçamos a importância de seus conceitos nos estudos da enunciação. Greimas e seus seguidores tem trazido reflexos interessantes sobre as categorias do tempo, espaço e pessoa, mas sobre uma outra abordagem, que não foi a que seguimos.

A linguagem se transforma em discurso oral ou escrito por meio da enunciação. Esta enunciação, sempre presente, pode produzir uma enunciação enunciada e um enunciado enunciado. Podemos ter, portanto, dois grandes grupos de momentos de referência temporal: o do mundo narrado e o do mundo comentado. Comparando-se esses dois mundos respectivamente com os tempos do então e do agora de Greimas, aplicamos a categoria topológica abaixo para casa um desses tempos, como dito na citação:

Considerando o tempo de então como tempo zero, e aplicando, a partir disso, a categoria topológica,

concomitância/não-concomitância

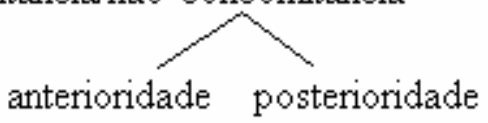

é possível construir um modelo simples do tempo enuncivo que, enquanto sistema de referência, permitirá localizar os diferentes programas narrativos do discurso. 
Na medida em que a instância da enunciação, tomada no seu conjunto, é suscetível de ser enunciada e de constituir, à maneira de um simulacro, a estrutura enunciativa do discurso, o tempo de agora, tomado separadamente, pode ser debreado e inscrito no discurso como tempo enunciativo relatado. O tempo de agora, assim enunciado, articula-se por sua vez de acordo com a mesma categoria topológica e constitui, no interior do discurso, um segundo sistema de referência temporal. (GREIMAS; COURTĖS, 2008, p.113-114).

Destas informações de Greimas e Courtès pudemos entender que a categoria topológica concomitância/não-concomitância (anterioridade $v s$ posterioridade) deveria ser aplicada a dois pontos zero: o ponto zero do sistema do então e o ponto zero do sistema do agora. Acreditamos que a marcação central "zero" da categoria topológica concomitância/não concomitância pertença, de um ponto de vista do órgão da linguagem, ao termo concomitância, pois é um caráter concomitante que adquire valor numérico igual a zero para que, só então a partir dele, haja mobilidade e transferência livre de informações temporais concomitantes a ele $(=0)$, anteriores a ele $(-0)$, ou posteriores a ele $(0+)$. Assim, aplicando a concomitância a um ponto zero do então e a um ponto zero do agora, temos:

Quadro 7. Categoria topológica aplicada ao agora e ao então, separadamente

\begin{tabular}{|c|c|c|c|c|c|c|}
\hline & \multicolumn{6}{|c|}{ presente pressuposto - centro gerador do discurso } \\
\hline INTENÇÃO & \multicolumn{3}{|c|}{$\begin{array}{l}\text { Subjetividade } \\
\text { AGORA }\end{array}$} & \multicolumn{3}{|c|}{$\begin{array}{l}\text { Objetividade } \\
\text { ENTÃ }\end{array}$} \\
\hline \multirow[b]{3}{*}{$\begin{array}{l}\text { Lugares } \\
\text { Mentais }\end{array}$} & \multirow{2}{*}{$\begin{array}{l}\text { Concomi- } \\
\text { tância }\end{array}$} & \multicolumn{2}{|c|}{ Não concomitância } & \multirow{2}{*}{$\begin{array}{l}\text { Concomi- } \\
\text { tância }\end{array}$} & \multicolumn{2}{|c|}{ Não concomitância } \\
\hline & & anterior & posterior & & anterior & posterior \\
\hline & $\begin{array}{l}\mathrm{MR} \\
\text { enunciativo } \\
\text { presente }\end{array}$ & $\begin{array}{l}\mathrm{MR} \\
\text { enunciativo } \\
\text { pretérito }\end{array}$ & $\begin{array}{c}\text { MR } \\
\text { enunciativo } \\
\text { futuro }\end{array}$ & $\begin{array}{c}\text { MR } \\
\text { enuncivo } \\
\text { presente }\end{array}$ & $\begin{array}{c}\text { MR } \\
\text { enuncivo } \\
\text { pretérito }\end{array}$ & $\begin{array}{c}\text { MR } \\
\text { enuncivo } \\
\text { futuro }\end{array}$ \\
\hline Eventos & $\begin{array}{l}\text { ME - MF } \\
\text { MF - ME } \\
\text { ME,MF }\end{array}$ & $\begin{array}{l}\text { ME - MF } \\
\text { MF - ME } \\
\text { ME,MF }\end{array}$ & $\begin{array}{l}\mathrm{ME}-\mathrm{MF} \\
\mathrm{MF}-\mathrm{ME} \\
\mathrm{ME}, \mathrm{MF}\end{array}$ & $\begin{array}{l}\text { ME - MF } \\
\text { MF - ME } \\
\text { ME,MF }\end{array}$ & $\begin{array}{l}\text { ME - MF } \\
\text { MF - ME } \\
\text { ME,MF }\end{array}$ & $\begin{array}{l}\text { ME - MF } \\
\text { MF - ME } \\
\text { ME,MF }\end{array}$ \\
\hline
\end{tabular}

Acontece que essa forma de atribuir valores à topologia é de ordem lógica.Isso significa que, por exemplo, se consideramos o presente enuncivo como um subsistema do tempo, ele se torna, de um ponto de vista dos estudos do discurso, uma armadilha, pois o que permite a construção de um programa narrativo de referência "presente enuncivo", por exemplo, será um programa narrativo pretérito subjacente a ele.

Quando se trata de temporalização do esquema narrativo (realmente simples), o tempo de então, que constitui o ponto de referência temporal, 
identifica-se com a realização do programa narrativo de base (ou prova decisiva) e pode ser considerado o "presente da narrativa": é a partir dessa posição que a narração que precede aparece como uma anterioridade [...]. (GREIMAIS; COURTES, 2008, p.297).

O tempo do então, entendido logicamente, se divide em passado, presente e futuro. Mas, o tempo do então entendido do ponto de vista do discurso, é considerado como uma anterioridade ou posterioridade, porque o tempo do então já é uma anterioridade estabelecida ao enunciador em relação às coisas que enuncia. Por exemplo:

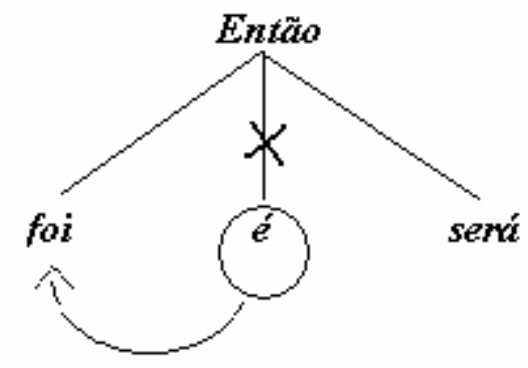

Figura 51 - A supressão da concomitãncia do tempo do então para uma anterioridade

Continuando a citação de Greimas e Courtès (2008, p.297):

Ao lado desse tipo de temporalização (em que o tempo então, enquanto presente narrativo, situa-se no "passado" do enunciador), existem evidentemente narrativas proféticas ou premonitórias que se referem ao "futuro" do enunciador. Entretanto, o futuro, longe de ser uma posição temporal, depende antes de tudo das modalidades do querer-ser ou do deverser, pelas quais o enunciador modaliza seu discurso; nesse sentido, optamos pela categoria topológica anterioridade/posterioridade, e não pela articulação passado/presente/futuro que conta com a preferência dos lógicos. As narrativas que cobririam o "presente" do enunciador evidentemente são apenas uma armadilha, já que esse presente, móvel, não pode servir de ponto de referência. São então os procedimentos de embreagem que servem para criar a ilusão de uma possível identificação do discurso com a instância da enunciação.

A localização temporal (GREIMAS; CORTÈS, 2008) consiste na inscrição dos programas narrativos no interior de unidades especiais ou temporais dadas, ou seja, na construção de um sistema de referências inscrito no discurso. De fato, pela enunciação, só podemos inscrever no discurso o que é concomitante, o que é anterior e o que é posterior a ele. O tempo do discurso é linear, e aquelas são as únicas formas possíveis de se falar do tempo. Entretanto, o mundo que resulta de uma criação da linguagem, o mundo possível, pode desenraizar-se de um enunciador, se vendo livre da exigência de um agente do discurso. A semântica do tempo comportaria uma bidirecionalidade. 
Esse modo de experimentação do tempo é bastante intuitivo. Por isso, na articulação do mundo narrado, ou de um mundo orientado por um então, há referências tanto a um passado e futuro, quanto a um presente.

A temporalidade do discurso semiótico, entretanto, ficará presa ao eu enunciativo, porque, de fato, é ele quem produz o discurso. Assim, todos os tempos ficam intrinsecamente relacionados ao Momento da Enunciação, que é o momento central de uma temporalidade do discurso.

Ao mundo possível, orientado pelos sentidos que os falantes naturalmente atribuem ao produto de uma comunicação, interessa-nos aquilo que é transmitido, e o que é transmitido pode ter referência, por exemplo, a um 'presente do passado', como é o caso do subsistema do presente enuncivo criado pela aplicação do termo concomitância ao então. De um ponto de vista lógico, a referência a um presente do passado seria mais precisa na descrição do tempo, embora seja uma "armadilha" (GREIMAS; COURTES, 2008, p.297) do discurso.

Como vimos no quadro 6, Fiorin (2008) esquematiza a temporalidade do discurso com os seus construtos ME (momento da enunciação), MR (momento de referência) e MA (momento dos acontecimentos). Nós, por outro lado, buscamos uma temporalidade semântica e lógica da linguagem utilizando os construtos de Reichenbach, os MRs e os MEs e os MFs (respectivamente, os momentos de referência, os momentos dos eventos e os momentos da fala). Este trabalho considera que possa haver seis subsistemas, ou seja, seis MRs. (agora concomitante, agora posterior, agora anterior, então concomitante, então posterior e então anterior), ou seis eixos (MRs) que servem de suporte para os tempos dos eventos (MEs). Um discurso, oral ou escrito, pode ser construído escolhendo-se um desses eixos de MRs ou mais.

Cada um desses seis subsistemas representa, como veremos mais adiante, um lugar temporal de referência, atualizado por um espaço mental, que vai servir de parâmetro para a ordenação dos eventos em relação ao momento da fala (MF). A ideia de Momentos de Referência lembra a de Fiorin (2008), pois este linguista também trata essa questão como um Momento de Referência. Entretanto, Fiorin nos alerta que sua teoria não deve se confundir com a do lógico Reichenbach ${ }^{46}$.

Os MEs (nosso Momento do Evento) podem ser concomitantes, anteriores ou posteriores a cada um dos Momentos de Referência, o que significa que, para cada um desses momentos, há um presente, um passado e um futuro. Há, portanto, uma noção de presente,

\footnotetext{
${ }^{46}$ Fiorin (2008) esclarece que sua proposta, apesar de lembrar a proposta de Reichenbach (1966), não se confunde com ela, porque este estudioso ancora seus "momentos" numa teoria lógica e não numa teoria da enunciação.
} 
passado e futuro de um presente dêitico e de um presente não-dêitico; uma de presente, passado e futuro de um passado dêitico e de um passado não-dêitico; e uma noção de presente, passado e futuro de um futuro dêitico e de um futuro não-dêitico. O tempo gramatical poderia ser definido como uma categoria que permite situar os acontecimentos como presentes, passados ou futuros, em relação a um marco referencial presente, passado ou futuro.

Cada subsistema (MR) comporta um eixo gerador de Momentos de Fala. Esse eixo, por sua vez, orienta os momentos dos eventos indicados principalmente por formas verbais, advérbios temporais e marcadores cronológicos de tempo. Por exemplo, o sistema enunciativo regido pelo MR presente, comporta as formas verbais do 'presente', do 'pretérito perfeito 1' e do 'futuro do presente" ${ }^{47}$. Vejamos um exemplo de um texto enunciativo presente:

(45) Agora irei apresentar uma comunicação sobre os últimos resultados da empresa. Vocês estão vendo este gráfico nitidamente? Hoje vocês perceberam como a tecnologia pode ajudar nas palestras!

Esse texto (45) apresenta verbos do sistema enunciativo presente. O eixo do sistema enunciativo presente possui um ponto lógico referencial zero que é o momento da fala (MF) norteador dos eventos (MEs). Ele representa cognitivamente um centro gerador e axial que se deslocaria, funcionando como um AGORA É QUE implícito, imaginado a cada tempo gramatical novo do enunciado.

(46) AGORA É QUE... Agora irei apresentar uma comunicação sobre os últimos resultados da empresa. AGORA É QUE... Vocês estão vendo este gráfico nitidamente? AGORA É QUE... Hoje vocês perceberam como a tecnologia pode ajudar nas palestras!

$\longrightarrow$ AGORA EOER

Figura 52 - O deslocamento cognitivo do Momento da Fala

\footnotetext{
${ }^{47}$ Estamos nos baseando na classificação que Fiorin (2008) fez dos tempos verbais em língua portuguesa nos três sistemas referenciais. O pretérito perfeito recebe uma classificação "1" porque também podemos encontrar essa forma temporal no subsistema enuncivo pretérito. Neste caso, o tempo verbal é classificado como pretérito perfeito 2 (FIORIN, 2008, p.148).
} 
Como o construto MF não é o momento da enunciação (que é sempre presente), ele pode se "transformar" em vários "agoras" enunciativos, graças aos mundos possíveis criados pela linguagem - no nosso caso, seis MFs (três agora e três então), uma vez que possuímos seis eixos enunciativos para que esses MFs marquem seu ponto central:

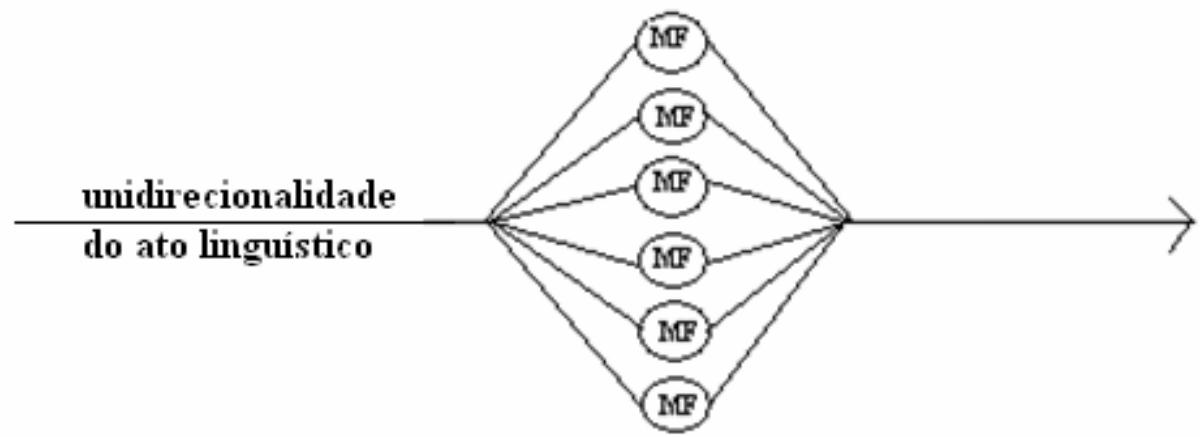

Figura 53 - Um texto pode gerar seis tipos de MF

O MF representa o centro lógico de um MR. Vejamos descritos, de outra forma, os seis eixos de MRs, três para o sistema do mundo comentado e três para o sistema do mundo narrado. Indicaremos, ao lado do nome de cada subsistema, como possivelmente poderia se comportar cognitivamente o seu centro MF.

Quadro 8. Os seis MRs

1- mundo comentado:

1.1 subsistema passado (MF = "agora foi/era que")

1.2 subsistema presente (MF = "agora é que")

1.3 subsistema futuro ( $\mathrm{MF}$ = "agora será que")

2- mundo narrado:

2.1 subsistema passado (MF = "então foi/era que")

2.2 subsistema presente ( $\mathrm{MF}$ = "então é que")

2.3 subsistema futuro (MF = "então será que")

Embora, como dissemos, um MF possa funcionar como um tempo de valor diferente do presente gramatical, ele se identifica, na atualização do discurso, com o presente pressuposto do ato da enunciação.

Cada um desses subsistemas pode ser entendido como um MR. Um discurso pode ser construído com um ou mais MRs. A intenção particular de cada falante é que decidirá qual ou quais MRs usará na sua enunciação. Estamos entendendo, portanto, um MR como uma 
parcela cognitiva de espaço-tempo, onde localizaremos as ações de um discurso. Segundo Reichenbach, o momento de referência pode ser definido como algo ocupando uma parte contínua e limitada de espaço e tempo. ${ }^{48}$

Depois de estabelecido, algumas vezes trocamos um tempo verbal que seria comum a um MR estabelecido, por um outro elemento temporal comum a um outro MR. Essa possibilidade de "troca", devida a uma neutralização, pode ser entendida como correspondendo às "[...] microembreagens (utilização de um tempo com valor de outro) [...]" (FIORIN, 2008, p.238), que serão vistas na subseção 4.3.5. Outras vezes, estabelecemos mais de um tipo de MR para a construção de um texto, o que nos faz pensar no conceito de embreagem entendida como "[...] um processo composicional que rege a relação global entre tempo da enunciação e tempo do enunciado.” (FIORIN, 2008, p.238), e no conceito de espaços mentais, que veremos na subseção 4.3.9.

A cada Momento de Fala (MF), os tempos dos eventos (ME) deslizam-se pelo eixo de referência à enunciação. O MF é a referência lógica para que os MEs se organizem. Cada eixo tem um centro de concomitância com o centro (MF) de enovelamento dos eventos. No caso do eixo do MR presente enunciativo, mais do que uma relação de concomitância, ele sempre corresponderá, de forma simulada, referencialmente com o momento da enunciação. Nestes casos, pode-se afirmar que o MF pode ser indicado pela data da produção do enunciado, por exemplo, a data de um jornal.

Os eventos - estados e transformações - dar-se-ão em relação ao MR escolhido e, mais especificadamente, em relação ao centro gerador e axial desse MR, que é o MF. Se um evento (Momento do Evento - ME) ocorre, por exemplo, anterior ao centro (MF) do momento em que se enovelam os estados e os acontecimentos, diz-se que esse evento ocorre num momento anterior: ME anterior. Portanto, os MEs são ordenados em relação aos diferentes MFs dentro de cada MR.

O exemplo (46) visto anteriormente exemplifica um dos seis eixos que aparecem descritos na figura 53 e no quadro 8: o MF de um MR presente enunciativo. É como se, a cada ponto zero deslocado, o enunciado instituísse um novo Momento da Fala.

Nos textos em que o foco está sobre os eventos em si (mundo narrado) possuímos um eixo zero de ordenação, entendido como um então. Da instância presente da enunciação podese abstrair um então. Ele se desloca ao longo do fio do discurso permanecendo sempre então $(\mathrm{MF}=0=$ então $)$ e, de um ponto de vista lógico resultante da localização temporal dos

\footnotetext{
${ }^{48}$ No original: We may define it (individual) as something occupying a continuous and limited part of space and time. (REICHENBACH, 1948, p.266 apud CORÔA, 1998, p.9).
} 
eventos, podemos ter um MR enuncivo presente, passado e futuro. Um exemplo de um texto enuncivo temporalmente seria:

(47) ENTÃO FOI QUE... eu teria apresentado uma comunicação sobre os últimos resultados da empresa aos meus colegas, mas ENTÃO FOI QUE... eles não viram os gráficos nitidamente. Certamente ENTÃO FOI QUE... eles tinham percebido como a tecnologia pode fazer falta.

O subsistema escolhido para exemplificar um sistema enuncivo em (47) foi o subsistema enuncivo passado.

\subsection{3 - MR enuncivo presente e o MR enunciativo passado e futuro}

Como vimos, Fiorin (2008) apresenta os seguintes sistemas do tempo:

Quadro 9.

A - sistema enunciativo (1)

B - sistema enuncivo:

B.1 - subsistema pretérito (2)

B.2 - subsistema futuro (3)

A partir desses três sistemas referenciais do tempo, Fiorin (2008) definiu quais os tempos verbais em língua portuguesa pertencem a cada sistema. Com base, portanto, nos tempos verbais, Fiorin passa a classificar os Momentos dos Acontecimentos como enunciativos ou enuncivos.

Entretanto, nesta Dissertação, consideramos temporalmente enunciativo qualquer texto que causar, entre os seus interlocutores, uma tensão, e consideramos temporalmente enuncivo qualquer texto que causar entre os seus interlocutores uma atitude "relaxada", mesmo que para isso um texto considerado por nós, por exemplo, como enuncivo se utilize de tempos verbais enunciativos previstos por Fiorin. Com isto, não estamos nos prendendo às 
formas verbais, mas à intenção do interlocutor em relação à atitude que quer "passar" ao locutário. Por exemplo:

(48) E naquela noite, após ela ter se deitado, abre-se a porta silenciosamente e entra, no quarto, um vulto encapuzado.

naquela noite $=$ marco temporal passado

abre-se e entra $=$ verbos no presente do indicativo

Enquanto Fiorin classifica o tempo verbal presente empregado em (48) como enunciativo, nós tomaremos outras expressões de tempo empregadas no enunciado para que, juntamente com o verbo, possamos nos referir a alguma classificação. Ao final, teremos um texto temporalmente enuncivo, porque com esse tipo de tempo verbal presente ${ }^{49}$ o texto demonstra fazer parte de um mundo narrado que, neste caso (o do presente histórico de que tratam as gramáticas), sempre vem marcado por um marco temporal passado. Consideramos que (48) seja um texto enuncivo porque percebemos que a atitude estabelecida entre os interlocutores é mais relaxada, situação em que o destinatário é um simples ouvinte (mundo narrado). O presente histórico parece-nos pertencer ao discurso dos relatos. Por isso, assim como há textos do mundo narrado, contados num eixo do passado e do futuro, há também textos do mundo narrado contados no presente, mas que por serem construídos com tempos verbais tipicamente de textos do mundo comentado, causa-nos uma certa "proximidade" enunciativa.

Deste modo, teremos que admitir que uma mesma forma verbal pode ocorrer tanto para descrever um mundo narrado (enuncivo) quanto um mundo comentado (enunciativo), e essa atitude não é muito positiva se se pretende descrever uma lista onde ocorram, de um lado, os tempos verbais enunciativos e, de outro, os tempos verbais enuncivos, ficando diferente de uma sistematização verbal mais tradicional da língua.

Fiorin (2008) prevê uma solução como essa, de duplicar os sentidos que as formas verbais podem apresentar - ora como enuncivas, ora como enunciativas -, mas não a adota e a

\footnotetext{
${ }^{49}$ Esse presente pode ser chamado de presente histórico. De acordo com as possibilidades de lugares referenciais estabelecidos nesta Dissertação, podemos dizer que há dois tipos de presente histórico: o presente do MR passado enunciativo e o presente do MR presente enuncivo. Este exemplo (48) seria um tipo de presente histórico do mundo narrado; na subseção 5.3, veremos exemplos de presente histórico do mundo comentado.
} 
julga "péssima", justificando que o sistema verbal da língua não poderia ter suas formas "repetidas" em duas listas de sistemas temporais ${ }^{50}$ :

Uma outra [solução] seria considerar que temos um presente, um pretérito perfeito 1 e um futuro do presente enunciativos e um presente, um pretérito perfeito 1 e um futuro do presente enuncivos. Os tempos que consideramos do sistema enuncivo teriam também um valor enunciativo e um enuncivo. No entanto, essa solução seria péssima, pois a teoria perderia toda a capacidade de explicar o sistema verbal da língua. O melhor é, pois, dizer que os tempos pertencem ao sistema eunciativo ou ao enuncivo e que é da ordem do discurso serem enunciativos enunciativos, enunciativos enuncivos etc. (FIORIN, 2008, p.237-238, grifo nosso).

De fato, uma sistematização quanto ao sistema verbal da língua fica prejudicada ao se dizer que uma mesma forma verbal aparece em dois sistemas, mas o que estamos tentando descrever é uma sistematização quanto ao sistema lógico temporal da língua que não se utiliza apenas da morfologia verbal para alcançar os sentidos de tempo desejados e possíveis.

Como podemos observar na citação acima, há uma outra classificação necessária em Fiorin (2008): enunciativo enunciativo, enunciativo enuncivo, enuncivo enunciativo e enuncivo enuncivo. Cada uma das quatro classificações é descrita por um sintagma formado de dois termos: o primeiro termo classifica a forma modotemporal do verbo; se é enunciativo, são os tempos do sistema do presente, se é enuncivo, são os tempos do sistema do passado e do futuro; o segundo termo do sintagma nomeia o valor discursivo que o enunciado em questão pode apresentar, ou seja, se apresentar valor de enunciação enunciada, é enunciativo, se apresentar valor de enunciado enunciado é enuncivo. Por exemplo, um verbo enunciativo que compõe um enunciado enunciado seria classificado como "enunciativo enuncivo".

Esta preocupação com uma debreagem do enunciado e uma debreagem da enunciação combina-se com a nossa preocupação de se pensar em discurso antes de se pensar em listas: em mundo narrado e mundo comentado (enuncividade e enunciatividade); em níveis de objetividade e de subjetividade em relação ao narrado; distanciamento e aproximação em relação à enunciação; etc. Gostaríamos, então, de classificar os tempos verbais como enunciativos e enuncivos, primeiramente porque a metalinguagem fica mais simples, depois e principalmente - porque nossa visão sobre a temporalidade não é da ordem de uma teoria do discurso, mas de um ponto de vista lógico e intuitivo sobre a experiência da linguagem. Assim, podemos dizer:

\footnotetext{
${ }^{50}$ Entretanto, quanto ao pretérito perfeito, essa "aversão" à duplicidade das funções verbais foi desconsiderada; como vimos, Fiorin diz que o pretérito perfeito pode ser tanto enunciativo (pretérito perfeito 1) quanto enuncivo (pretérito perfeito 2).
} 
- MR Presente enunciativo

- MR Presente enuncivo

- MR Passado enunciativo

- MR Passado enuncivo

- MR Futuro enunciativo

- MR Futuro enuncivo

Insistimos que a teoria greimasiana sobre o tempo se refere a uma temporalidade do discurso, e a nossa, a uma temporalidade semântica da linguagem. A temporalidade do discurso irá exigir uma relação de subordinação entre a debreagem da enunciação e a debreagem do enunciado: "[...] a debreagem do enunciado é subordinada à da enunciação." (FIORIN, 2008, p.237). Nós, por outro lado, tomaremos a experiência do tempo do texto sem essa subordinação. Como a nossa temporalidade é semântica, o efeito de tempo sentido pelo produtor/receptor será ou de tensão (debreagem da enunciação) ou de distensão (debreagem do enunciado), porque essas duas formas de experimentação da relação entre enunciador e enunciatário são lineares, pois ao se conscientizar numa dada apropriação de um texto enuncivo de que este é subordinado a uma enunciação, o enunciador não está mais "distenso" no tempo, mas sob tensão. Há, portanto, uma fronteira feita entre situações comunicativas (Weinrich, 1968).

Por exemplo:

(49) Naquele dia - já lá vão dez anos! -, o Dr. Félix levantou-se tarde, abriu a janela e cumprimentou o sol $^{51}$.

O tempo é semanticamente ora enuncivo:

(49 a) Naquele dia...

Ora enunciativo:

(49 b) Já lá vão dez anos!

E ora enuncivo novamente:

(49 c) ...o Dr. Felix levantou-se tarde, abriu a janela e cumprimentou o sol.

Em (49 b) há um retorno a uma situação de tensão que não se estabelecia antes deste enunciado. É por isso que se pode considerar uma "embreagem composicional"

\footnotetext{
${ }^{51}$ Machado de Assis. Ressurreição. In.; Obra completa em quatro volumes. Rio de Janeiro: Nova Aguilar, 2008, v.1, p.236.

${ }^{52} \mathrm{O}$ mesmo exemplo aparece em Fiorin, 2008, p.238.
} 
Uma das características dos textos enunciativos é deixar sempre implícito uma relação de tensão entre os interlocutores. No caso dos textos construídos com o subsistema enuncivo do presente, há uma intenção de não "comprometer" o destinatário na comunicação. Vejamos o seguinte exemplo de modalidade escrita:

(50) Eu pego a sacola e procuro as chaves. São 10h quando viro a esquina procurando me desviar de um pedestre. Chego no supermercado e encontro você que está nesse exato momento na porta de entrada.

Seria estranho considerar esse texto como enunciativo temporalmente, porque o destinatário, no exato momento em que lê nesse exato momento, não está na porta de entrada do supermercado, mas está simplesmente decodificando um interlocutor que está relatando alguma coisa. O exemplo acima não é um exemplo de uma comunicação enunciativa estabelecida temporalmente. $\mathrm{O}$ destinatário não se reconhece como parte atuante em um plano temporal atual em relação ao enunciatário, mas ele está anterior (mundo narrado) a ele; o destinatário apenas se vê como enunciatário. Quem lê o exemplo (50) interpreta uma segunda pessoa, mas não se compromete em se "vestir" desse "você" instalado pelo "eu", porque o modo como o exemplo foi escrito não pede que a relação entre os interlocutores seja de comprometimento. Não há um enunciador que convida o destinatário a estabelecer um jogo temporal de tensão sobre o enunciado. Para que houvesse uma enunciação, o exemplo não seria constituído num subsistema enuncivo de presente, mas, sim, num sistema enunciativo de presente, com textos do tipo: Eu sei que é difícil, leitor, mas continue lendo! Neste caso, o leitor mantém uma relação de tensão e de comprometimento com seu interlocutor.

Vejamos, agora, mais alguns exemplos de textos enuncivos no presente:

Não sei o que me leva a pular a janela e ir atrás das crianças. Quando me vejo de cuecas no pátio, já não posso recuar com naturalidade. Tenho pelo menos de apertar a mão do velho, mas ele me evita, me desconhece e sai de lado, olhando para o fundo do copo vazio. As crianças dispersam-se, e as duas motos vigiam-me do platô. Miram na minha direção, e vou me retirando sem olhar para trás. Ouço o ronco dos motores, e tenho pressa em alcançar a varanda. Quando pulo para dentro do quarto, vejo que elas vêm descendo em ponto morto, serpenteando no talude. Embicam na varanda, de frente para a minha janela, enquanto acabo de me vestir. (HOLLANDA, 1991, p 31).

Quanto ao sistema enunciativo passado e futuro, nos baseamos na noção bühleriana de dêixis 'am Phantasma'. 
Segundo Fonseca (1992, p.58), K. Bühler, na década de 30 do século passado, em sua obra Sprachtheorie, 1934, foi o primeiro teorizador da linguagem a desenvolver de forma consistente uma concepção enunciativa do sujeito, adotando a noção de eu-origem. O conceito de sujeito em Bühler começa a ser tratado como uma noção operatória necessária para a explicação do funcionamento da língua. Fonseca afirma que o conceito de subjetividade bühleriano já era entendido num sentido que anunciaria mais tarde Benveniste. "Bühler é o mais significativo dos precursores modernos da teoria da enunciação, facto que não tem sido suficientemente posto em relevo." (FONSECA, 1992, p.59).

Vejamos o exemplo:

(51) Depois de amanhã começo meu regime.

A forma verbal "começo" é um acontecimento posterior ao momento da enunciação enunciada. Em um exemplo parecido com o nosso, Fiorin (2008, p.197) explica:

No entanto, essa posterioridade é manifestada pelo presente. Nesse caso, o presente é prolongado até o futuro, para denotar a certeza da ação futura. O futuro é sempre uma expectativa. Por isso, quando é expresso pelo presente, cria-se o efeito de sentido de certeza, afastando-se a nuança semântica de hipótese. Por esse motivo, o futuro próximo, sentido como de realização inevitável, é mais suscetível de ser manifestado pelo presente.

Não podemos considerar o tempo do enunciado (51) levando-se em conta somente a informação temporal do verbo; entendemos que devemos levar em conta a locução adverbial temporal depois de amanhã. Nesse primeiro momento, parece fácil entender que há uma somatória de fatores deste enunciado resultando num valor de "futuro certeiro":

Quadro 10. Depois de amanhã começo meu regime

\begin{tabular}{|l|l|}
\hline Locução adverbial empregada no enunciado: & futuro + \\
\hline Valor temporal morfológico do verbo: & "presentificação da ação" = \\
\hline Sentido temporal total do enunciado: & "futuro certeiro" \\
\hline
\end{tabular}

Para que se entenda o valor do presente do verbo começo no seu lugar enunciativo de MR futuro, é preciso que o falante possua um campo mostrativo dêitico criado pela linguagem que não é o seu aqui-agora, mas um aqui-agora futuro. Bühler apresenta uma teoria em que podemos encontrar essa dêixis criada pela linguagem: a dêixis "am Phantasma". Ele distingue, "[...] na linguagem verbal, três campos mostrativos correspondentes a três modos de 
mostração: dêixis 'ad oculos', anáfora e dêixis 'am Phantasma' [...]." (FONSECA, 1992, p.87- 91):

- Dêixis 'ad oculos': é a mostração verbal e consequente localização dos objetos presentes no campo mostrativo situacional;

- Anáfora: é uma forma de mostração linguística derivada, resultante da transposição do modo de funcionamento da dêixis 'ad oculos' para o espaço textual;

- Dêixis 'am Phantasma': é a possibilidade de apontar, usando os dêiticos, para seres, objetos ou acontecimentos situados num campo mostrativo imaginário, feito por meio da linguagem.

A diferença entre a dêixis fantasma e a dêixis 'ad oculos' é que esta não precisa de um campo de linguagem contextual anteriormente criado, pois a situação de comunicação real forma as coordenadas para o campo contextual da dêixis 'ad oculos'. A dêixis fantasma forma a dêixis a partir de marcas no texto (mas que não se confunde com a anáfora). Ninguém faz criações sem "avisar”. "Como é possível apontar para o que está ausente?” (FONSECA, 1992, p.143). E este aviso é um aviso "(con)textual”; a referência fantasma não se cria sozinha, precisa de um contexto; esse contexto é geralmente textual. Por exemplo, em Amanhã eu estudo Matemática ${ }^{53}$, o contexto estaria sendo marcado pelo advérbio amanhã.

No exemplo Quebrou, pagou! $!^{54}$ - com valor de "Se você quebrar, terá que pagar como entender o campo mostrativo desse comentário (portanto, mundo cometado)? Acreditamos que para a contextualização do campo mostrativo "fantasma", além de fatores textuais, existem fatores culturais entre os falantes de uma língua. Por exemplo, a forma Quebrou, pagou! pode representar uma forma já cristalizada que a nossa língua portuguesa possui para se referir a questões "hipotéticas", uma vez que não são poucas as expressões desse tipo. Por exemplo, "Pegue e pague", "Comprou, ganhou”, “Tomou, passou”, "Caiu, bateu, doeu, passa Gelol que passa", etc. O contexto, nesses casos, seria cultural.

[..] a dêixis 'ad oculos' e a anáfora têm como traço comum o facto de serem ambas mostração 'in praesentia' (o campo mostrativo é acessível pela sua proximidade sensorial ou por ainda estar presente na memória imediata). Este traço distingue-as da deixis 'am Phantasma', que é a mostração 'in absentia', isto é, num campo mostrativo só acessível mentalmente (re)construído a partir de dados fornecidos pela memória mediata (memória a longo prazo). (FONSECA, 1992, p.150).

\footnotetext{
${ }^{53}$ Trata-se do exemplo (1) analisado anteriormente.

${ }^{54}$ Trata-se do exemplo (3) analisado anteriormente.
} 
Vejamos agora uma outra questão:

(52) Agora eu era herói.

Sobre esse novo exemplo, extraído de um conhecido verso da música de Chico Buarque, poderemos encontrar nos estudos linguísticos explicações do tipo:

Quadro 11. Agora eu era herói

\begin{tabular}{|l|l|}
\hline Advérbio de tempo empregado no enunciado: & presente + \\
\hline Valor temporal morfológico do verbo: & pretérito imperfeito = \\
\hline Sentido temporal total do enunciado: & Presente de "faz de conta" \\
\hline
\end{tabular}

Com uma explicação um pouco diferente, Fonseca (1994) diz, sobre esse verso, que não se trata da "junção" de um presente (agora) e um pretérito (era), mas, antes, da junção de dois presentes: da fusão entre um presente real e um presente fictício. Ou seja, o tempo verbal era, no pretérito imperfeito, não funciona apenas como operador de uma localização temporal ou referenciação temporal relativamente ao agora da enunciação, mas como operador de uma criação transposta à enunciação. Esse verbo teria o seu marco de referência temporal fictivo ${ }^{55}$. Demonstraremos essas ideias de Fonseca em um novo quadro:

Quadro 12. Agora eu era herói segundo Fonseca (1992)

\begin{tabular}{|l|l|}
\hline Advérbio de tempo empregado no enunciado: & presente + \\
\hline Valor temporal morfológico do verbo: & $\begin{array}{l}\text { pretérito imperfeito }+ \\
\text { algum dispositivo }= \\
\text { presente fictício }\end{array}$ \\
\hline Sentido temporal total do enunciado: & Presente de "faz de conta" \\
\hline
\end{tabular}

A linguista começa a pensar se existem operações enunciativas específicas de um determinado modo de referência: “[...] haverá, na estrutura das línguas, um dispositivo formal da ficção?" (FONSECA, 1994, p.90).

\footnotetext{
${ }^{55}$ Essa referência fictiva, Fonseca (1992) explica que remonta a K. Bühler, que já em 1934 fala de uma dêixis "Phantasma".
} 
Podemos pensar em outro exemplo um pouco mais "estranho" temporalmente que o exemplo (52), e que se parece com o exemplo (3) Quebrou, pagou! (cujo contexto seja de algo ainda não quebrado, ou seja, com uma enunciação que diz, por exemplo, "Se quebrar, vai pagar"). O seguinte exemplo poderia nos causar essa suspeita que Fonseca tem a respeito de existir ou não uma referência especifica para alguns tipos de texto:

(53) Só amanhã: comprou um refrigerador, levou uma batedeira.

Neste exemplo (53), encontrado em um anúncio publicitário brasileiro, cujo sentido pode ser entendido como "Se você comprar um refrigerador, nós te daremos, de graça, uma batedeira", fica ainda mais difícil imaginar uma tabela com a soma de todos os valores temporais para se descobrir o sentido temporal total do enunciado.

Quadro 13. Só amanhã: comprou um refrigerador, levou uma batedeira.

\begin{tabular}{|l|l|}
\hline Advérbio de tempo empregado no enunciado: & futuro + \\
\hline Valor temporal morfológico dos verbos: & $\begin{array}{l}\text { Pretérito perfeito }+ \\
\text { Dispositivo fictício } ?=\end{array}$ \\
\hline Sentido temporal total do enunciado: & Passado de "faz de conta" \\
\hline
\end{tabular}

Podemos entender esse passado de comprou e levou como um passado fictivo, assim como foi fictivo o futuro em (51) Depois de amanhã começo meu regime.

Esses exemplos nos provam que os enunciados pertencentes a um mundo comentadoporque estabelecem entre os interlocutores uma situação de tensão e comprometimento - não se estabelecem apenas em um momento enunciativo presente, mas em um momento enunciativo futuro e, em alguns casos de presente histórico, em um momento enunciativo passado.

\subsection{4 - Tempo do Relato - Reenunciação}

Devemos nos lembrar do tempo implicado nos discursos construídos pelos narradores. Os reenunciados são os diálogos, os "conhecidos" discurso direto, discurso indireto e discurso 
indireto livre. Podemos usar o termo reenunciação (ou mesmo diálogo) ao invés do termo discurso para não confundirmos o termo discurso com aquele termo entendido como um modo de enunciação responsável pelo surgimento desse tipo de enunciado. A reenunciação é a possibilidade de um ato de enunciação produzir outro ato de enunciação, seja por meio da conversação ou da escrita:

No livro As marcas lingüisticas da enunciação histórica, de Milton José Pinto (1994), por exemplo, aparecem três sistemas: experiencial (da experiência, enunciativo, do tempo presente), narrativo (tempo da história, passado, do mundo narrado) e do relato (é o que envolve as três espécies de discurso: direto, indireto e indireto livre, mais especificamente o indireto). Este último sistema provém de quando eu relato, eu trago o discurso de outra pessoa para o meu. Dou a conhecer ao meu interlocutor o discurso de outra pessoa através do meu. (PONTES-RIBEIRO, 2007, p.29).

Nós já vimos - no exemplo (44) - que quando um narrador relata, ele traz um discurso e, consequentemente, o tempo da pessoa que discursa, e isso é algo bastante intuitivo para o falante. Há, então, sistemas próprios para o relato. Precisamos da categoria de pessoa da enunciação nesse caso para mostrar que há uma subordinação de tempos, devida a uma subordinação de pessoas, e esta subordinação de pessoas leva a uma subordinação de tempos.

Para que isso fique mais claro, pensemos em uma obra literária. Quando temos uma obra em primeira pessoa, o autor é entendido como o enunciador; o "eu" do livro é entendido como narrador, e se este delegar voz $^{56}$ a algum personagem, este personagem passa a ser o narrador em um novo plano, o chamado interlocutor. Em semiótica, se diz que essa delegação de vozes é um processo que se dá instituindo graus de debreagem:

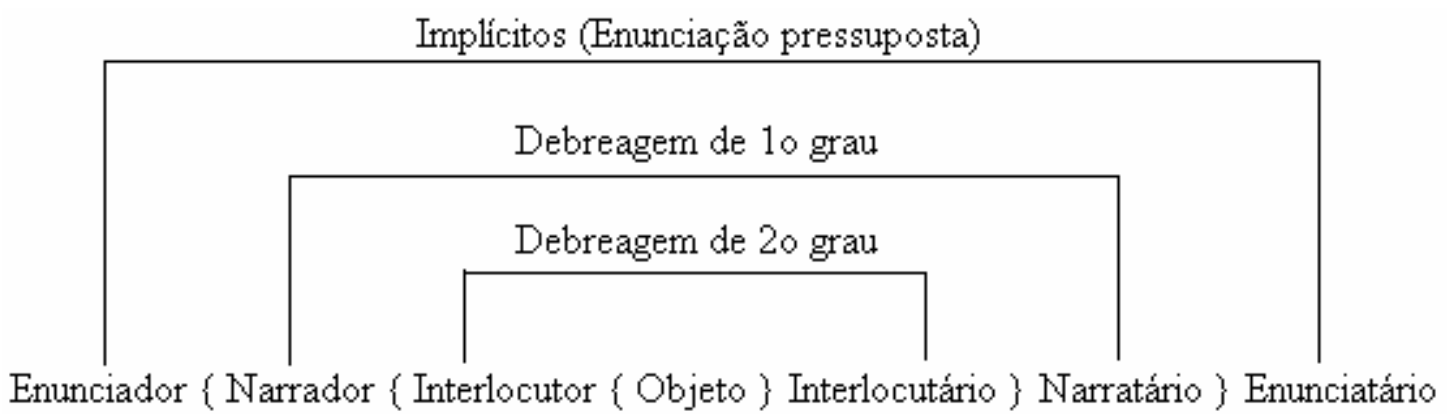

Figura 54 - Os graus de debreagem (FIORIN, 2008, p.69)

\footnotetext{
${ }^{56}$ A delegação de vozes também se dá, e é muito natural, na conversação ordinária, quando reproduzimos (imitamos) a fala de alguém.
} 
Podemos ter vários graus de debreagem, como podemos ver nos exemplos abaixo:

(54) Paulo disse a Pedro: o Cláudio disse "O Miguel disse 'Eu sou feio!'”,

(55) Paulo disse a Pedro que Cláudio disse que o Miguel disse que ele mesmo era feio.

A noção de reenunciação é muito importante no desenvolvimento de um esquema modelar da concatenação do tempo porque ela nos esclarece que não devemos misturar, por exemplo, os tempos narrados pela enunciação do narrador com os tempos narrados pela enunciação do personagem.

Um discurso direto e um discurso indireto são mutuamente conversíveis segundo um jogo de transformações de modos, tempos e pessoas verbais, e de formas pronominais e adverbiais. E essa reversibilidade deve ser observada com cuidado. Por exemplo:

(56) Pedro diz: - Eu estou morrendo de vontade de dormir agora.

(57) Pedro diz que está morrendo de vontade de dormir agora.

(58) Pedro diz que quer dormir.

Nem sempre a oração subordinada substantiva objetiva direta como em (58) quer dormir corresponde necessariamente a um enunciado original (56) - Estou morrendo de vontade de dormir agora. Em (57), temos uma reenunciação indireta em relação a (56); em (58) não.

Às vezes, um enunciado pode parecer ser um discurso indireto, mas não ser. A reenunciação só é tal porque consegue que o reenunciado atribua claramente um enunciado original a outro ser ou ao próprio reenunciante que o pensou (enunciados mentais) ou o proferiu. O reenunciado pressupõe um enunciado anterior. Em (58) não há reenunciação porque não há anteriormente um enunciado do tipo:

(59) Pedro diz: - Eu quero dormir.

Acreditamos que não há produção de reenunciados indiretos feitos com enunciados do mundo comentado. Quando se reproduz o diálogo de alguém indiretamente, se está narrando este diálogo. Isto significa que os verbos dicendi, empregados nesse uso, introduzem uma oração sempre do mundo narrado, ou enunciva. A reenunciação retoma (narra) e não produz (comenta) um enunciado original. O reenunciado em (57), ou seja, a oração que está 
morrendo de vontade de dormir agora seria uma narração de (56). O enunciado (58), por não constituir uma reenunciação, seria apenas um comentário de (56).

Este modo de entender uma reenunciação pode ser utilizado para explicar outras questões. É que as conversões de tempos dos reenunciados indiretos para enunciados originais podem ser realizáveis ou não. Nesta questão, diremos que esta questão vai depender da intenção do falante: narrar ou comentar.

(60) - Irei depressa.

(61) Ele disse que iria depressa.

(62) Ele disse que irá depressa.

O falante poderá reenunciar o enunciado (60) conforme queira narrar ou comentar, escolhendo qual o relevo vai atribuir para seu enunciado. Para nós, o exemplo (61) possui uma "verdadeira" reenunciação (que iria depressa) porque ele faz as conversões de tempos, tornando-se um relato exato de (60). Já no exemplo (62), não há, ao nosso ver, um reenunciado, mas apenas um comentário de um enunciado como (60). Entretanto, a Gramática analisa os exemplos (61) e (62) como discursos indiretos de $(60)^{57}$.

\subsection{5 - Quando um ME é utilizado em um MR ao qual não pertencia}

Embora os acontecimentos futuros sejam normalmente narrados com tempos do futuro, eles podem, por exemplo, ser descritos com tempos do passado. A situação presente pode ser narrada como se já tivesse acontecido, usando termos do passado. O mesmo acontece quando acontecimentos passados - e que normalmente são descritos com tempos do passado são descritos com tempos do presente - tradicionalmente chamado pelas gramáticas de presente histórico. Quando isso acontece, significa que o falante quis trazer um sentido diferente do sentido trazido com um texto escrito com tempos empregados segundo uma "orientação natural".

\footnotetext{
${ }^{57}$ Sobre essa questão, $c f$. Chociay (1979).
} 
Esta forma de construir um texto é, em um primeiro momento, estranha, por ser menos natural do ponto de vista da referência: termos passados deveriam narrar acontecimentos passados, termos presentes deveriam narrar acontecimentos presentes, e termos futuros deveriam narrar fatos vindouros.

Depois de estabelecida a forma com que se vai narrar os acontecimentos, pode acontecer de o uso de um determinado tempo verbal, ou advérbio temporal, ser usado por um outro termo (ME), comum a um outro sistema de referência (MR).

De acordo com uma teoria cognitiva, podemos tratar os casos do uso de um tempo verbal por outro por meio do processo de integração. A integração é um processo cognitivo muito importante e muito comum nas nossas vidas. Trata-se de integrar um fenômeno a outro.

Ao longo do nosso processo evolutivo, sempre foi uma grande vantagem ser capaz de integrar eventos, principalmente os de causa e efeito. Integrar o rugido de um leão à presença dessa fera poderia salvar uma vida. [...] Esse processo de integração ocorre por blending (em português mesclagem) dentro de nossa mente, criando insights globais. Esses insights permitem tanto prever acidentes quanto pensar criativamente. (ABREU, 2010, p.40).

No caso do presente histórico, integramos um momento passado a um momento presente por um processo de compressão do tempo. Para estabelecer o sentido de um enunciado que, por exemplo, contém um presente histórico, precisamos abrir um espaço mental para estabelecermos a referência temporal, transpondo o momento presente para o momento da referência do passado, integrando por compressão o tempo e o espaço desses dois momentos. Abrimos, então, um outro espaço mental que é resultado dessa composição, em que se imagina que é presente aquele momento passado.

Para entender como um tempo verbal, que pertence a um dado MR, passa a fazer parte de um outro MR, discutiremos também o conceito de embreagem da teoria semiótica. Para isso, vejamos o seguinte exemplo:

(63 a) Em 22 de abril de 1500, Cabral tinha descoberto o Brasil.

b) Quatro dias depois celebra-se a primeira missa em terras brasileiras.

Neste exemplo (63), usaríamos o termo embreagem para nomear o mecanismo de passagem de um centro referencial no primeiro enunciado (que, para nós, se classifica em sistema enuncivo do passado) para outro centro referencial no nosso segundo enunciado (sistema enuncivo do presente). 
Greimas e Courtès (2008) afirmam que a embreagem causa uma "ilusão referencial" ou "ilusão enunciativa", porque ela acaba "denunciando" que a referencialidade linguística é uma ilusão. Acontece que, quando não se encontra embreagem em um texto, é mais sensível perceber que um discurso possui esses mecanismos de projeção para fora da instância da enunciação dos tempos verbais. Em outras palavras, quando não há embreagens, há debreagens, que é a teoria semiótica para o modo como a linguagem cria sua referencialidade, e por isso encontramos a afirmação de que quando temos textos "debreados", sem sofrerem embreagens, temos “[...] a impressão de estar sempre em presença de uma temporalidade nãolingüística [...]" (FIORIN, 2008, p.191), porque é como se esquecêssemos que é a língua quem cria o tempo.

Contar para alguém algo que aconteceu no dia anterior, se referindo a um "ontem" (tempos do "dizer"), é natural, assim como contar para alguém algo que aconteceu a mil anos atrás, se expressando com "era uma vez", é natural. Natural no sentido de que parece que a língua está refletindo o mundo do jeito que ele é cronologicamente. É claro que não precisaríamos de muito esforço para ver que a língua não reflete realmente o mundo. Por exemplo:

- sabemos que o amanhã de hoje será um hoje amanhã;

- percebemos que as "previsões proféticas" sobre o fim do mundo em 2001 ficaram estranhas lidas nos anos seguintes a 2001 - isto se essas profecias foram narradas com verbos do subsistema enuncivo do futuro (MR enuncivo futuro);

- o romance de ficção científica "2001: Uma Odisséia espacial”, de Arthur C. Clarke, por ser narrado com verbos do subsistema do passado (MR passado), causava um "estranhamento temporal" ao leitor que a leu entre a data em que foi escrita (1968) e a data de sua referência narrativa (2001), mas, se lermos a obra hoje, ela não nos causará uma quebra de perspectiva temporal ${ }^{58}$, porque se narra uma história passada do ponto de vista de hoje, por meio de uma construção textual do passado.

Poderíamos dizer que essas ideias pertencem a um mesmo princípio que define as embreagens.

Sabemos que ocorre uma embreagem quando o homem opera com a linguagem de forma a não fazer condizer os termos reais da sua enunciação com a sua situação discursiva,

\footnotetext{
${ }^{58}$ A não ser, é claro, o estranhamento do conteúdo ficcional da obra, pois, por exemplo, até hoje o homem não conseguiu chegar em Júpter.
} 
ou textual, criada na comunicação. Para ficar um pouco mais claro, vejamos um exemplo de embreagem actancial. Quando um prefeito enuncia aos seus eleitores:

(64) - O prefeito dessa cidade é amigo de vocês.

o prefeito deveria ter dito "eu" e não um "ele", para condizer com os termos reais do ato de comunicação. Devemos observar que ele poderia ter dito que "é amigo dos eleitores" ao invés de "amigo de vocês". Essa marca enunciativa da comunicação, a segunda pessoa do plural, reforça o fato de ter ocorrido uma embreagem em "prefeito". Outro fato que denuncia a embreagem é, obviamente, a pessoa do prefeito que é quem diz "ele" numa situação de enunciação em que se refere a ele mesmo.

Esse enunciado (64) apresenta uma debreagem enunciva, porque uma forma enunciva da categoria de pessoa foi usada no lugar de uma enunciativa, não permitindo uma debreagem enunciativa ("Eu sou amigo de vocês"). Esse "usar no lugar" pela neutralização é o mecanismo da embreagem; neste exemplo, trata-se de uma embreagem actancial, porque a categoria que se neutraliza é a de pessoa.

Vejamos um exemplo de embreagem temporal:

(65) - O Coringão voltou! O Coringão voltou! (Grito ensaiado pela torcida corinthiana, no jogo Corinthians vs Ceará, dia 25 de outubro de 2008, no estádio do Pacaembu $-\mathrm{SP})$.

Muitos torcedores presentes naquele referido jogo do Corinthians, ao perceberem que o seu time já tinha alcançado a pontuação necessária para uma vaga na série A, fizeram uma "embreagem coletiva", entoando que seu time voltou para a série A. Trata-se de uma embreagem porque os torcedores deveriam ter cantado "O Conringão voltará", uma vez que eles ainda estavam num campeonato da série $\mathrm{B}$, com mais quatro jogos pela frente, e, por isso, não poderiam estar, ao mesmo tempo, na série $\mathrm{A}$.

Outro exemplo de linguagem oral:

(66 a) - Luiz, você quer assistir à peça do Wagner Moura em Santa Catarina? b) - Opa, já "tô" lá. 
Em 66 (b) há uma embreagem, cuja debreagem pressuposta é aquela em que uma pessoa responderia nesse ato de discurso que, no futuro, "estará lá", ao invés de dizer que “agora está lá". Um falante que profere "já 'tô' lá" resolve fazer uso da embreagem pelo desejo de alcançar um MR que não é o seu MR "real”. Nesse caso, o ME é posterior ao seu momento real por causa do advérbio lá. Como o falante não pode estar lá nesse espaço-tempo da peça em Santa Catarina e, ao mesmo tempo, estar aqui-agora (verbo ser - "tô" interpretado "ao pé da letra") falando com seu interlocutor, porque o ser humano não é onipresente (nem mesmo enunciativamente), podemos dizer que ele se finca em um contexto enunciativo futuro, enunciativamente fictivo ${ }^{59}$, em que o sujeito se vê em um tempo presente. A prova de que ele não pode estar lá em Santa Catarina é a sobra de uma marca da enunciação do eu-aqui-agora: o "lá". Se Luiz tivesse dito - Opa, já estou aqui!, o enunciado não seria compreensível. Luiz comete uma embreagem porque está inserido num contexto em que ocorrem debreagens enunciativas reais, e ele faz outro tipo de debreagem, uma debreagem fictiva. A embreagem sempre pressupõe uma debreagem anterior, e, como vimos, deve deixar alguma marca discursiva da debreagem anterior.

O seguinte exemplo:

(67) Amanhã ele vai ao cinema.

Apresenta uma embreagem, e a marca contextual que denuncia esse mecanismo é amanhã. Esse tipo de passagem só é possível porque há a neutralização de uma forma por outra, princípio básico da embreagem temporal.

Quando temos, em um texto narrado com tempos enuncivos passados, um narrador em terceira pessoa, e este narrador institui uma debreagem de segundo grau a um personagem que enuncia um texto formado com tempos enunciativos, passamos de um MR enuncivo passado para um MR enunciativo presente. Essa passagem poderia ser considerada uma embreagem, pois seria uma quebra de ilusão narrativa (função primeira da embreagem) o fato de estarmos mergulhados num mundo narrado onde, "de repente", há personagens que parecem estar conversando aqui-agora. "o diálogo, inserido num dado discurso narrativo, referencializa este último, enquanto a narrativa 'fictícia', debreada a partir desse diálogo, torna 'real' a situação do diálogo.” (GREIMAS e COURTÈS, 2008, p.531).

Vejamos outros exemplos:

\footnotetext{
${ }^{59}$ Como vimos, o termo "fictivo" foi inspirado na definição de "tempo fictivo" de Fernanda Irene Fonseca (1992) que, por sua vez, foi inspirada na noção de dêixis "am Phantasma" de Bühler.
} 
Um texto escrito no eixo de um MR enuncivo passado com uma embreagem de reposicionamento no eixo de um MR presente:

(68) Corria o ano de 1944, e a culpa do colonialismo mal começara a despontar. Vien se tornaria o responsável pelas relações culturais do governo de Saigon com o exterior e publicará uma História do Vietnã ${ }^{60}$

Um texto escrito no eixo de um MR enunciativo presente com uma embreagem de reposicionamento no eixo de um MR enuncivo passado:

(69) A julgar pelo comportamento do ministro e de seus assessores é nisso que estão pensando: numa forma de dolarização crescente, processo que no seu final seria capaz de dar um alivio à moeda brasileira e aplacar o foguete dos preços. ${ }^{61}$

Outro:

(70) - Ele não quer que eu fique solteira toda a vida, não?

- Não tem poder para isso. Mas bem que queria, acho. Ou não sabes, maninha? ${ }^{62}$

Um texto escrito no eixo de um MR enuncivo passado com uma embreagem de reposicionamento no eixo de um MR enuncivo presente:

(71) Estava toda linda, porque tinha ido ao cabeleireiro à tarde, era a mais arrumada da festa quando, você não acredita, me jogam um copo de cerveja na cabeça! E, o pior, entro no banheiro para me lavar e quem eu encontro? Ela, rindo de mim! (simulação de uma conversa)

Em (71), começa-se o narrado com tempos do passado, depois com tempos do presente.

Exemplo de um texto escrito no eixo de um MR enuncivo passado com uma embreagem de reposicionamento no eixo do MR enunciativo presente:

\footnotetext{
${ }^{60}$ CALVET, J. L. 1993, p.74 apud FIORIN, 2008, p.211.

${ }^{61}$ Revista Veja, 22/9/1993 apud FIORIN, 2008, p.212

${ }^{62}$ VIEIRA, J. G. 1970, p.136 apud FIORIN, 2008, p.228.
} 
(72) - Agora... Era uma vez o bicho papão. O Bicho papão era muito guloso. (vira-se a página) - Agora... Numa bela noite, o bicho papão saiu para assustar uma criancinha. (vira-se a página) - Agora... Ele estava muito faminto e... (Simulação de uma mãe lendo um livrinho para uma criança)

Se ao lermos um livrinho pequeno - desses breves e especiais para criança, e que são escritos no tempo enuncivo do passado - formos, a cada página virada, introduzindo à criança uma apresentação dessa página com um "Agora...", quebramos o mundo narrado em que a criança é mergulhada, para lembrá-la que há um mundo comentado que a subordina. Mas é só no começo de cada página, e logo a criança é envolvida em uma situação de relaxamento entre quem conta a história e ela.

Um texto escrito no eixo de um MR enuncivo passado com uma embreagem de reposicionamento no eixo de um MR enuncivo presente:

(73) E naquela noite, após ela ter se deitado, abre-se a porta silenciosamente e entra, no quarto, um vulto encapuzado ${ }^{63}$.

A seguinte tabela é uma tentativa de mostrar os eixos que compõe (73) em unidades em sequência. São dois eixos de referência (MR) e quatro instalações de MF.

Quadro 14. Unidades em sequência, do exemplo (73)

\begin{tabular}{|c|c|c|c|}
\hline $\begin{array}{l}\text { E naquela noite, } \\
\mathrm{ME}-\mathrm{MF}\end{array}$ & $\begin{array}{l}\text { após ela ter se deitado, } \\
\text { ME - MF }\end{array}$ & $\begin{array}{l}\text { abre-se a porta silenciosamente } \\
\text { MF,ME }\end{array}$ & $\begin{array}{l}\text { e entra, no quarto, um } \\
\text { vulto encapuzado } \\
\text { MF,ME }\end{array}$ \\
\hline \multicolumn{2}{|c|}{--------------então foi que----------------- } & \multicolumn{2}{|c|}{----------------------------então é que------------------------ } \\
\hline
\end{tabular}

Um texto escrito no eixo de um MR enuncivo presente com uma embreagem no eixo de um MR enunciativo presente:

(74) Então vou ao supermercado, pego o caderno - Eita caderno barato e imundo! -, $e$ vou ao caixa rápido.

\footnotetext{
${ }^{63}$ Trata-se do mesmo exemplo (48), visto anteriormente.
} 
Quadro 15. Unidades em sequência, do exemplo (74)

\begin{tabular}{|c|c|c|}
\hline Estou no supermercado, pego o caderno & - Eita caderno barato e imundo! - & E vou ao caixa rápido. \\
\hline -----------. & ------------Agora é que --------- & ---------Então é que - \\
\hline
\end{tabular}

\subsection{6 - O tempo cronológico na enunciação enunciada}

$\mathrm{Na}$ enunciação enunciada, as coordenadas temporais são dadas pelo discurso. Mas o que permite a lógica temporal de cada posicionamento temporal do discurso é o fato de a linguagem tratar também do posicionamento do tempo real: o tempo cronológico. Há, portanto, expressões linguísticas que são pontos de referência temporal fixos culturalmente como o tempo do calendário. Aliás, o falante está sempre pressuposto em um tempo histórico. Portanto, a natureza linguística do tempo, embora seja dêitica (tempo subjetivo), reflete uma outra natureza objetiva, que é o tempo semântico-referencial (tempo cronológico).

Há bons exemplos na comunicação oral e na literatura para mostrar que estamos presos a um referencial cronológico. Na obra de Richard Matheson, Bid Time Return (1987), ou Em algum lugar do passado, o narrador Richard Collier quer contar ao leitor os fatos que estão acontecendo na sua vida a partir do seu ponto de vista dêitico na data cronológica em que se encontra, ou seja, 1971. Há um momento em que Collier viaja no tempo, indo para o passado de 1896. Neste passado, Collier continua narrando os fatos que vão acontecendo na sua vida de um ponto de vista dêitico em relação à data em que se encontra: 1896. Nessa atitude, ele encontra alguns problemas linguísticos para descrever sua situação atual:

O balcão de recepção também mudara de lugar, situando-se agora à direita do elevador onde, anteriormente (deveria dizer eventualmente?), eu via o saguão aberto e a janela-guchê da tabacaria." (MATHESON, 1987, p.109).

Neste trecho, o narrador repensa no uso que fez da palavra anteriormente. Como a ação que narra nesse exemplo acontece em sua vida num momento agora, fazendo com que todas as outras ações da sua vida sejam "tempos passados", o narrador se confunde, porque o assunto que narra não acontece num tempo cronológico esperável, mas num tempo cronológico de 1896, ou seja, anterior cronologicamente a 1971. O tempo subjetivo de Collier 
tratado neste exemplo seria representado pelo termo anteriormente, mas quando ele pensa em usar uma relação com o tempo objetivo (cronológico), surge a dúvida, e ele questiona usar o termo eventualmente ou posteriormente ${ }^{64}$.

O mesmo acontece com esse outro trecho da obra:

Déjà $v u$, pensei, quando cheguei ao balcão e olhei através do Átrio Aberto. Embora sua aparência fosse muito diferente - ainda não havia a exuberância das plantas tropicais: figueiras, limoeiros, laranjeiras, goiabeiras, romãzeiras e semelhantes -, a impressão que tive foi semelhante à da primeira manhã em que me vira no hotel. Exceto pela lógica, naturalmente, aquilo não podia ser descrito como déjà $v u$, uma vez que isto significa "estive aqui antes" e, de fato, não estaria lá, por um período de 75 anos." (MATHESON, 1987, p.159).

O termo déjà $v u$ só seria adequado à situação vivida por Collier se o tempo passado em que viveu (quando pela primeira vez observou o Átrio Aberto) fosse também passado na cronologia do tempo real comum. Como não é, não se poderia dizer que sua visão anterior é um passado, de um ponto de vista cronológico, e não seu.

Mesmo entendendo o mundo do discurso como um "mundo possível”, e, por tanto, diferente de um mundo real, os exemplos acima nos mostram que há alguns limites na construção linguística do tempo.

Segundo Benveniste (2006, p.73), "O sistema obedece a necessidades internas que são coersivas. O eixo de referência não pode ser mudado, uma vez que é marcado por algo que realmente aconteceu no mundo, e não por uma conversão revogável.”. O tempo crônico é fixo e imutável. "Se ele não fosse fixo, estaríamos perdidos em um tempo errático e todo nosso universo mental não teria como se orientar [...]" e “[...] nenhum discurso sensato poderia mais ser mantido sobre nada e a história inteira falaria a linguagem da loucura.”.

Na obra Em algum lugar do passado utilizada como exemplo percebemos que não só a linguagem utilizada por Collier sofre uma coerção - para usarmos o termo de Benveniste do sistema, como sua própria relação amorosa é coersiva, pois o tempo crônico (ou cronológico) o impede de viver ao lado da sua amada, "punindo-o" por tentar voltar ao passado dele, para estar no presente dela.

\footnotetext{
${ }^{64} \mathrm{O}$ termo original para eventualmente é eventually.
} 


\subsection{7 - A natureza psicológica do MR}

O MR pode ser considerado um sistema identificável psicologicamente. Mesmo os estudos gramaticais tradicionais dão explicações do tipo psicológicas para a natureza do que estamos identificando como MR, ou seja, o que estamos identificando como o MR de Reichenbach é, geralmente, associado a um tempo psicológico nos estudos gramaticais. Por exemplo, sobre o pretérito imperfeito, encontramos em Cintra e Cunha (1985, p.439): “[...] pelo pensamento nos transportamos a uma época passada e descrevemos o que então era presente $[\ldots] "$.

Essa questão é antiga dentro dos estudos gramaticais. Como aponta Ilari (2001) em seu livro A expressão do Tempo em Português, Jerônimo Soares Barbosa, um importante gramático do século XVIII, já tinha descoberto a necessidade de correlacionar cronologicamente três momentos distintos, como podemos ver em sua Grammatica Philosophica (1822, p.150 apud ILARI 2001, p.14) quando trata do pretérito mais-queperfeito:

Este pretérito nota uma existência não só passada, como o pretérito imperfeito, e não só passada e acabada indeterminadamente, como o pretérito absoluto, e não só passada e acabada relativamente à época atual, como o presente perfeito; mas passada e acabada relativamente a outra época também passada, mas há mais tempo, e marcada ou por um tempo determinado, ou por um fato, quer expresso, quer subentendido, como quando digo: ontem, ao meio dia, tinha eu acabado esta obra; onde meiodia é a época a respeito da qual, e antes dela era já passada e acabada a obra. E quando digo: eu tinha saído quando ele entrou; a entrada é também uma época pretérita a respeito da presente em que estou falando. Mas, minha saída não só é anterior e passada, mas ainda concluída e acabada a respeito da dita entrada.

Vejamos, agora, algumas formas verbais simples do indicativo, acompanhadas da sistematização de Reichenbach, tentando entender a formalização proposta por este lógico, ao mesmo tempo em que expomos nossa interpretação dos seus três construtos:

- $\quad$ O pretérito imperfeito possui um MR interessante. Como ele é um verbo usado normalmente para a construção de discursos do mundo narrado, seu centro lógico MF não poderá se identificar com o ponto zero dêitico da enunciação de forma lógico-referencial, mas apenas organicamente na ativação do discurso. O MR do pretérito imperfeito é anterior ao 
momento da enunciação porque o plano do discurso faz com que nos fixemos em um mundo narrado anterior.

À semelhança do pretérito perfeito usado no mundo narrado (aquele do tipo 2), o pretérito imperfeito é um tempo simultâneo ao momento temporal zero (MF) do sistema de referência MR. Por meio do quadro 8, vimos que o centro gerador de um enunciado do mundo narrado de um sistema passado, é um "então era/foi que". Isso significa que embora o pretérito imperfeito seja anterior ao momento da enunciação, o eixo central do sistema temporal enuncivo passado é o pretérito imperfeito (ou, em alguns casos, o pretérito perfeito 2), e a correspondência se dá no funcionamento discursivo entre momento da enunciação e MF. O esquema de Reichenbach não mostra essa correspondência: em ME,MR - MF, o momento da fala (MF) não demonstra a relação de tensão com o ME. Como veremos, nas nossas fórmulas, também não apresentaremos essa correspondência, porém a correspondência será uma condição prevista e estabelecida por nós. O MF, além de representar um presente, um passado ou um futuro de acordo com o tempo de seu MR, também irá funcionar sempre como um presente $(\mathrm{t}=0)$ concomitantemente ao centro gerador e axial do discurso.

- $\quad$ No pretérito mais-que-perfeito, o MR aparece, em Reichenbach, entre ME e MF, ou seja, ME - MR - MF. Por exemplo:

(75) Eu tinha entregado o relatório quando ele me pediu para dar uma olhada.

Isso significa que para se ter um pretérito do tipo pretérito mais-que-perfeito é necessário ter em mente um foco temporal passado, porém, mais futuro que um outro tempo passado. O foco num tempo passado nada mais é do que a sensação de estarmos compartilhando um enunciado do mundo narrado, neste caso, um enunciado enuncivo passado.

Se observarmos a seguir o que acontece com o pretérito perfeito, ficará mais claro para nós a classificação do discurso quando de mundo narrado ou de mundo comentado:

- O pretérito perfeito nos estudos de linha reichenbachiana é classificado como ME - MR,MF. Ou seja, com o sistema de referências identificado com o momento da fala. Exemplo:

(76) Ontem a Júlia foi à casa dos seus pais. 
Nesse exemplo, se não tivéssemos o nosso sistema de referência orientado no momento da fala, não compreenderíamos a expressão dêitica ontem. Porém, essa forma verbal (pretérito perfeito) pode ser usada tanto em discursos do mundo narrado quanto do mundo comentado.

(77) No dia anterior, muitas coisas aconteceram: a Julia foi para a casa dos seus pais, entrou assustada e revelou a noticia que deixaria todo mundo perplexo.

Os termos aconteceu, foi, entrou, revelou indicam concomitância em relação a um momento de referência passado, que é indicado por no dia anterior. Esses eventos, assim como o momento de referência "no dia anterior", são anteriores ao momento da fala, uma vez que se trata de um texto do mundo narrado, e, por isso, devemos ficar situados no sistema do plano da história, que, neste caso, é pretérito também: portanto ME,MR - MF (de acordo com Reichenbach). Esta opção de interpretação do pretérito perfeito pode ser comparada com a interpretação de Fiorin (2008), que distingue um pretérito perfeito do sistema enuncivo e um pretérito perfeito do sistema enunciativo, quando pensou nas formas em francês passé composé e passé simple. O primeiro expressa a anterioridade em relação a um momento presente (Reichenbach: ME - MR,MF), o segundo expressa concomitância em relação a um momento passado (Reichenbach: ME,MR - MF).

\subsection{8 - Como os MEs e os MFs se dispõem em uma esquematização}

A maneira como o leitor toma conhecimento dos acontecimentos é estabelecida pela escolha da ordem de disposição dos Momentos de Eventos (ME de Reichenbach) em relação ao MF, e pela escolha do(s) MR(s). Cada MF tem o seu próprio eixo onde se ordenam os tempos dos eventos (MEs). Ou seja, depois de feita a escolha do MR, é feita a escolha dos tempos dos eventos, escolhendo-se quais expressões gramaticais de tempo serão utilizados dentro dele. Por exemplo, em uma mesma escolha de MR, pode-se escolher enunciar como no exemplo (78) ou como no exemplo (79): 
(78) Coloco o ovo depois que despejei o óleo; em seguida, adicionarei o açúcar. $O$ bolo está pronto.

(79) Despejo o óleo, coloco o ovo e adiciono o açúcar. O bolo está pronto.

Há, portanto, um quarto nível da temporalidade da linguagem (nível D); depois do nível estabelecido pela escolha do MR, há o nível do tempo em que os acontecimentos ocorrem nesse eixo pelos ME.

Em (79), há uma linearidade de eventos reais, correspondendo a uma linearidade de eventos linguísticos: em primeiro lugar aparece o ME do óleo; em segundo aparece o ME do ovo; em terceiro aparece o ME do açúcar. Em (78), não há essa linearidade: primeiro aparece o ovo, depois o óleo e depois o açúcar. Para entender (78) cronologicamente é necessário um cálculo lógico que é operado graças a termos do tipo antes, depois, entre, etc.

Vejamos mais alguns exemplos dessa linearidade $v s$ cálculo:

(80) Eu nunca mais comerei carne de porco. Esta foi uma decisão que tomei depois de comer um pedaço estragado que eu comprei quando sai de casa numa bela tarde de domingo.

(81) Numa bela tarde de domingo, eu sai de casa e comprei uma carne de porco. Depois de comer um pedaço estragado eu tomei a decisão de nunca mais comer carne de porco.

Graças aos mecanismos da linguagem e à nossa compreensão da causalidade, não precisamos contar histórias apenas na ordem cronológica como em (81), ou seja, de modo linear cronologicamente. Isso acontece porque enquanto os eventos só podem ser dispostos de forma crescente da esquerda para a direita, porque respeitam a função referencial do seu objeto que é o tempo enquanto fenômeno real - como ocorreu com a nossa exemplificação da estrada de Clarck (1975), contendo eventos discretos (figura 16) -, as formas linguísticas desses eventos podem ser "lidas", isto é, interpretadas, tanto da esquerda para a direita (do passado para o futuro), quanto da direita para a esquerda (do futuro para o passado).

Esses dois modos de narrar (cronologicamente ou anacronicamente) pedem esquematizações um pouco diferentes, porque necessitam de quantidades diferentes de reposicionamento do MF. Exemplos: 
(82) Coloco o ovo depois que despejei o óleo; em seguida, adicionarei o açúcar. $O$ bolo está pronto ${ }^{65}$.

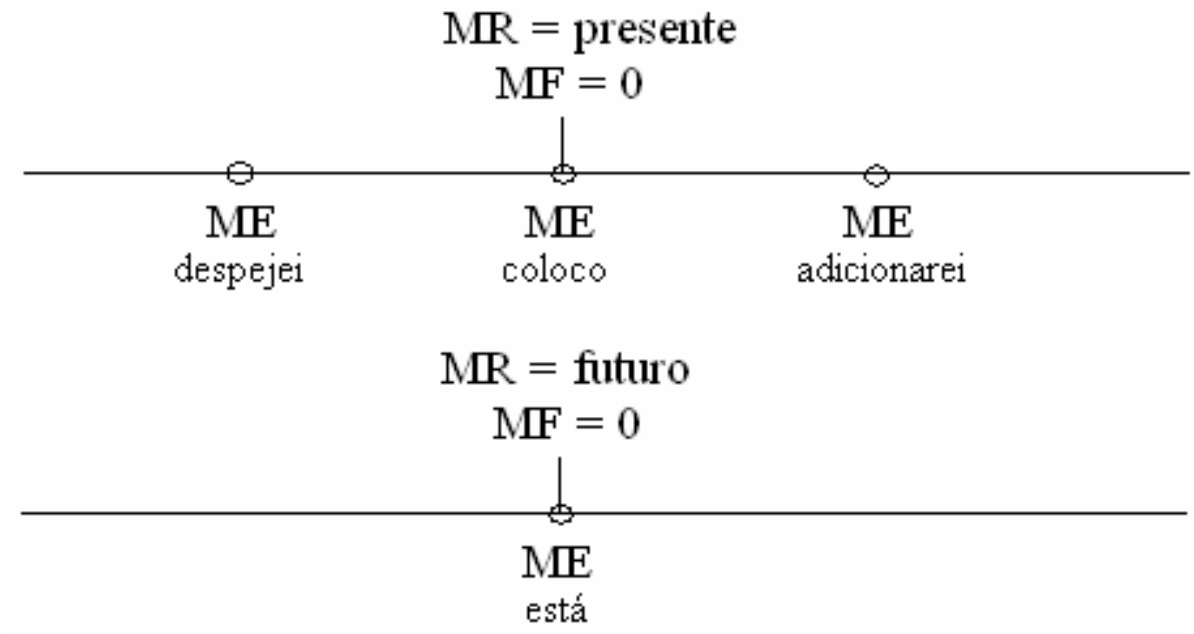

Figura 55 - Esquema do exemplo (82)

Há, nessa esquematização, duas linhas do tempo porque há dois Momentos de Referência: um (MR = presente) faz referência ao "colocar", "despejar" e "adicionar" no preparo do bolo; o outro $(\mathrm{MR}=$ futuro) faz referência a um presente fictício: tem-se um momento de referência estabelecido no futuro, no qual o bolo que está sendo preparado estará pronto, de fato. Isto acontece porque é difícil imaginar que, logo após a descrição do preparo do bolo, este realmente esteja pronto. Melhor seria se encontrássemos a seguinte afirmação:

(83) Coloco o ovo depois que despejei o óleo; após isso, adicionarei o açúcar. O bolo estará pronto em 30 minutos.

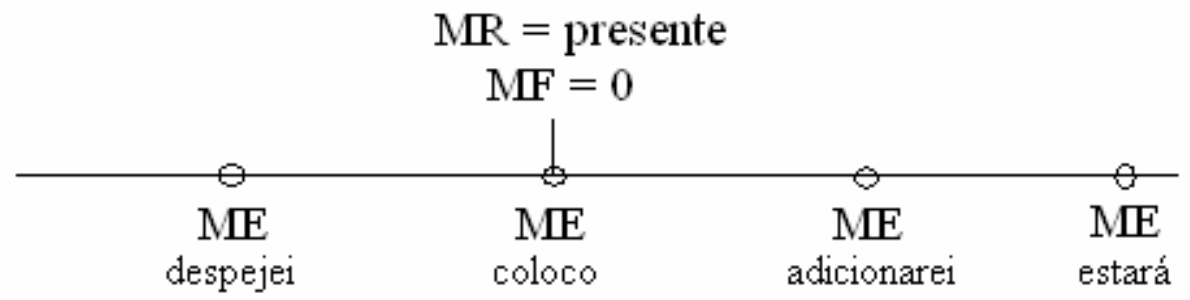

Figura 56 - Esquema do exemplo (83)

ou

\footnotetext{
${ }^{65}$ Retoma-se em 82 o exemplo 78.
} 
(84) Coloco o ovo depois que despejei o óleo; após isso, adicionarei o açúcar. Agora, tendo-se passado 30 minutos, o bolo está pronto.

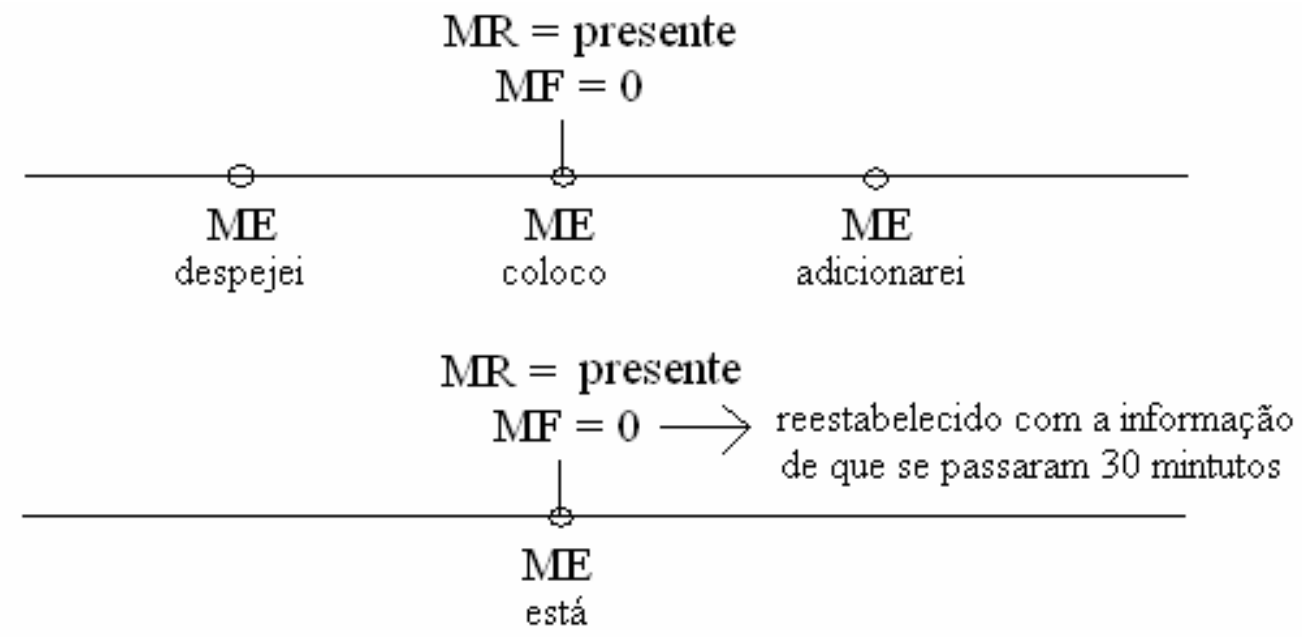

Figura 57 - Esquema do exemplo (84)

Vejamos a esquematização de um outro exemplo:

(85) Despejo o óleo, coloco o ovo e adiciono o açúcar. O bolo está pronto ${ }^{66}$.

\begin{tabular}{c}
$\mathrm{MR}=$ presente \\
$\mathrm{MF}=0$ \\
\hline $\mathrm{ME}$ \\
despeio \\
$\mathrm{MF}=0 \rightarrow$ reestabelecido \\
\hline $\mathrm{ME}$ \\
coloco \\
$\mathrm{MF}=0 \rightarrow$ reestabelecido \\
\hline $\mathrm{ME}$ \\
adiciono \\
$\mathrm{MF}=0 \rightarrow$ reestabelecido \\
\hline $\mathrm{ME}$ \\
$\mathrm{está}$
\end{tabular}

Figura 58 - Esquema do exemplo (85)

${ }^{66}$ Retoma-se em 85 o exemplo 79. 
O MR do enunciado $O$ bolo está pronto em (85) foi interpretado como o esquema (57), ou seja, como um MR presente, mas poderia ser considerado um MR futuro, com uma enunciação num presente fictício, como em (55).

Como se percebe na esquematização do exemplo 85 , podemos ter uma sequência de eventos no tempo, marcada por uma sequência linguística desses eventos, que requererão uma referência temporal, um MF, para cada evento, uma vez que os enunciados, que acompanham uma linearidade na linguagem, também acompanham uma linearidade no tempo. Quando isso ocorre, os MEs podem ser marcados com várias linhas de tempo de MRs.

Outras vezes, podemos ter eventos descritos de forma não linear, e por isso, por meio de mecanismos da linguagem como tempos verbais, advérbios, etc, podemos enunciar ações utilizando uma mesma linha do tempo (como o exemplo 83).

Vejamos mais uma esquematização:

(86) No dia anterior, muitas coisas aconteceram: a Julia foi para a casa dos seus pais, entrou assustada e revelou a notícia que deixaria todo mundo perplexo ${ }^{67}$.

$\mathrm{MR}=$ passado (A)
$\mathrm{MF}=0$
$\mathrm{ME}$
aconteceram

\begin{tabular}{c}
$\mathrm{MR}=$ passado $(\mathrm{B})$ \\
$\mathrm{MF}=0 \rightarrow$ reestabelecido \\
\hline $\mathrm{ME}$ \\
foi
\end{tabular}

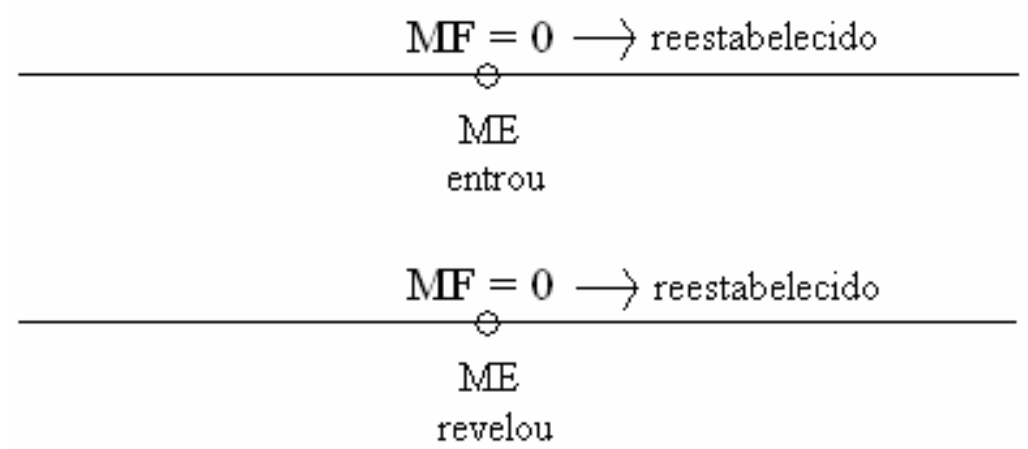

Figura 59 - Esquema do exemplo (86)

\footnotetext{
${ }^{67}$ Retoma-se em 86 o exemplo 77.
} 
Neste esquema, o MR é passado por causa, principalmente, da informação "no dia anterior" do enunciado. É nesse plano passado de referência que se instala um ponto zero: o Momento da Fala. Os eventos (MEs) ficam localizados concomitantemente ao centro MF. Neste caso, o pretérito perfeito é o centro lógico temporal do sistema de MR passado.

Como podemos perceber, a figura 59 ilustra dois MRs: o MR (B) é cronologicamente anterior ao MR (A), mas, de acordo com a linearidade da linguagem, o MR (A) se realiza como ato discursivo anterior ao MR (B).

Essa esquematização necessitou de várias linhas do tempo, porque ela opera com vários espaços mentais. Os trabalhos de Reichenbach e de seus seguidores só contemplaram o nível da frase. Essa ilustração que repõe várias linhas do tempo ganha um poder explicativo um pouco maior.

$\mathrm{Na}$ introdução deste trabalho, dissemos que há uma aparente simplificação, por exemplo, entre o pretérito perfeito e o pretérito mais-que-perfeito, em alguns contextos, por estarem sendo utilizados apenas pelo pretérito perfeito. Este fato pode ser observado nas reportagens de jornal. Nesse caso, o que parece ocorrer, para nós, é uma diferença no modo de compor MFs, e não uma mera simplificação de uso dos tempos verbais. A diferença de composição de MFs é que deve ser o mecanismo diferenciador na geração de sentidos; é diferente contar uma história que utiliza um "jogo" de composição entre as formas de pretérito perfeito e pretérito mais-que-perfeito, do que aquela história que se utiliza apenas de pretérito perfeito.

Inicia-se, neste ponto, uma outra grande questão: como a linguagem determina que a compreensão do tempo do discurso siga uma sucessão, de acordo com o que se pretende dizer, sem misturar o passado, presente e futuro dos verbos, com o passado presente e futuro do discurso? Cagliari (1988) discutiu essa questão afirmando que há alguns elementos que funcionam como "portas do tempo" que fazem com que o MF seguinte de um enunciado seja presente e faça com que o MF posterior a ele seja um passado, mesmo que tenhamos, nos dois casos, dois presentes.

Assim, uma sucessão de tempos verbais presentes, por exemplo, pode atravessar uma dessas portas e, do outro lado, passar a significar algo passado, com relação ao que sucede nesse novo espaço (ou nível) temporal. Essas portas do tempo conectam dois níveis temporais, correlacionando-os e criando uma nova dimensão temporal, a do discurso, composta de localizações temporais de passado, presente e futuro, não mais estabelecidas pelas marcas verbais, mas por esses "níveis temporais". (CAGLIARI, 1982, p.6). 
A ideia de "portas do tempo" também serviria para aqueles Momentos da Fala pertencentes a eixos de MRs diferentes, como vimos em muitos exemplos acima:

Desse modo não é mais preciso dizer que a língua usa um tempo por outro, como o presente pelo futuro em exemplos do tipo (1)

(1)Amanhã vou ao cinema.

Em exemplos como (1), o tempo é sempre presente no nível morfológico (quanto ao significante e quanto ao significado), e é futuro no nível temporal do discurso, isto porque a palavra "amanhã", que é uma "porta do tempo", estabelece um nível temporal próprio, diferente daquele do verbo, e este último diz, nesse tempo futuro, que a ação será realizada num tempo presente. É preciso passar por essa porta, e se colocar no outro plano temporal. (CAGLIARI, 1982, p.6).

Essa proposta viabiliza os seis Momentos de Referência que defendemos. Como vimos, os seis MRs são simples sistemas de presente, passado e futuro, somado ao fato de poderem ser ora enunciativos ora enuncivos. Defender que não há a colocação de um tempo verbal no lugar de outro (como o verbo no presente utilizado com valor de futuro em Amanhã estudo Matemática) é defender que possuímos em nossa mente imagens de lugares temporais, onde qualquer tempo verbal presente, passado ou futuro possa manter seu sentido de presente, passado ou futuro, respectivamente.

Vejamos um exemplo de um enunciado característico de um texto jornalístico:

(87) Um homem de 35 anos entrou no apartamento da ex-namorada e atirou duas vezes para o alto. A jovem correu assustada e um vizinho chamou a polícia pelo telefone.

Este é um exemplo de um texto construído com vários verbos no tempo pretérito perfeito. Como no exemplo (86), a esquematização de (87) exigiria várias linhas temporais com seus MFs e, portanto, várias portas do tempo. "Estas portas mudam o presente da enunciação" (CAGLIARI, 1982, p.10), porque na passagem de um bloco temporal do discurso para outro, o eixo enunciativo se reposiciona em um centro de concomitância com o presente implícito da enunciação.

A conjunção "e" (seguida de vírgula - com pausa ou sem), colocada estrategicamente no início de um bloco, onde ocorrem vários níveis temporais interligados, significa, em termos de sua função temporal no discurso, o início de uma nova cronometragem, ou, como se disse, de um "bloco". Obviamente, o texto é feito de blocos, e estes se relacionam uns com os outros na estrutura maior do texto. (CAGLIARI, 1982, p.10).

E ainda: 
A conjunção "e", além do valor analisado acima, caracteriza-se, no nível do discurso, por introduzir um nível temporal presente com relação a um antecedente, do nível anterior, ao qual ela se refere. Isto acontece como se, no nível do discurso realizado, o momento da enunciação se deslocasse na estrutura temporal montada, e não fosse algo "fora" do discurso. (CAGLIARI, 1982, p.12).

Portanto, dentro das questões que viemos trabalhando, são as "portas do tempo" as responsáveis pelo reestabelecimento de Momentos da Fala (MF), seja de um evento para outro em um mesmo MR, como o exemplo (86), seja de um momento referencial para outro, como (1) Amanhã estudo Matemática - neste último caso, um MF de um MR futuro passa por uma "porta do tempo" e, do outro lado, se torna um MF de um MR presente.

\subsection{9 - Os Momentos de Referência e os Espaços Mentais}

Na subseção 3.5, discutimos algumas questões sobre a teoria dos Espaços Mentais de Fauconnier (1984). Essa teoria nos ajuda a gerenciar melhor as informações temporais que aparecem no discurso. "A teoria dos espaços mentais promove uma solução elegante e explicações para vários problemas difíceis na lógica, na semântica, e na compreensão do discurso." ${ }^{68}$ (KÖVECSES, 2006, p.261).

Os espaços mentais permitem a organização de diferentes parcelas de informação. A semelhança de uma régua (KÖVECSES, 2006, p.267) que contém várias marcações, um discurso também pode ser visto contendo vários "tamanhos" de espaços mentais. Tanto na régua quanto no discurso, podemos formar vários agrupamentos, bastando apenas saber "focar" qual será a medida desse agrupamento. Por exemplo, se comparamos uma régua de 30 centímetros com a aquela mesma reportagem de revista que utilizamos na subseção 3.5, podemos fazer várias organizações conceituais:

- 30 centímetros é uma maneira de interpretar toda a régua, assim como um tempo passado é uma maneira de interpretar toda a reportagem;

- se olhamos para a régua tendo como medida de agrupamento dez em dez centímetros, teremos uma visão tripartida da régua, assim como podemos perceber três grandes

\footnotetext{
${ }^{68}$ No original: Mental space theory provides elegant solutions to and explanations of several difficult problems in logic, semantics, and the understanding of discourse.
} 
noções de tempo da reportagem: o tempo do relato sobre Jolie - marcado com (1); o tempo da conversa de Jolie, o discurso direto - marcado com (2); e o tempo do relato do filme - (3):

(1) Poucos meses após dar à luz os gêmeos Knox Leon e Vivienne Marcheline, na França, Angelina Jolie está de volta ao corpo magro e anguloso de antes. Como fez isso? (2) "Tenho seis filhos e amamento!", (1) diz ela, 33 anos que parecem 20, sorrisão, Ralph Lauren da cabeça aos pés - calça e malha bege-clarinha e sapatos de salto de 7 centímetros. No luxuoso hotel Waldorf Astoria, em Nova York, a atriz está recebendo jornalistas do mundo todo, que vieram saber um pouco mais sobre seu novo filme, $A$ TROCA, dirigido por Clint Estwood, e que estréia no Brasil em 2 de fevereiro.

(3) No drama, baseado em fatos reais, Angelina interpreta Christine Collins, telefonista e mãe solteira em Los Angeles, nos anos 20, que um dia volta do trabalho e não encontra o filho. Walter Collins tinha 7 anos quando desapareceu de casa. A história piora: meses depois, a polícia anuncia que encontrou o menino e chama a imprensa para registrar o encontro, mas a mãe não o reconhece. Na época, a polícia de Los Angeles era tão corrupta que fazia qualquer negócio para que ninguém investigasse suas falcatruas. Só que essa mãe quer a verdade, custe o que custar.(1) Contar mais é estragar a história. Basta dizer que os críticos prevêem uma segunda indicação ao Oscar para Angelina, que levou o prêmio de coadjuvante em 2000 por GAROTA, INTERROMPIDA. A atriz conta que fazer $A$ TROCA teve para ela uma "função terapêutica", pois ajudou-a a superar a dor da perda de sua mãe, Marcheline, que morreu em janeiro de 2007. (2)"Posso dizer que mais ou menos representei minha mãe nesse filme. É ela que vejo quando assisto ao filme, e Brad a vê também.'

- De cinco em cinco centímetros que se interpreta a mesma régua, pode-se pensar nos lugares temporais, ou seja, no tempo de cada plano inercial, ou momento referencial, marcando-se:

1) - Comentários gerais da revista

(2) - Comentários observados durante o tempo da entrevista

3) - Tempo em que Angelina Jolie dialoga

(4) - Tempo do comentário do filme

(5) - Tempo da narração do filme no seu início

(6) - Tempo da narração do filme, com referência a "meses depois"

(2) Angelina Jolie está de volta ao corpo magro e anguloso de antes. Como fez isso?(3) "Tenho seis filhos e amamento!", (2) diz ela, 33 anos que parecem 20, sorrisão, Ralph Lauren da cabeça aos pés - calça e malha bege-clarinha e sapatos de salto de 7 centímetros. No luxuoso hotel Waldorf Astoria, em Nova York, a atriz está recebendo jornalistas do mundo todo, que vieram saber um pouco mais sobre seu novo filme,

(4) No drama, baseado em fatos reais, Angelina interpreta Christine Collins, telefonista e mãe solteira em Los Angeles, nos anos 20 ,(5) que um dia volta do trabalho e 


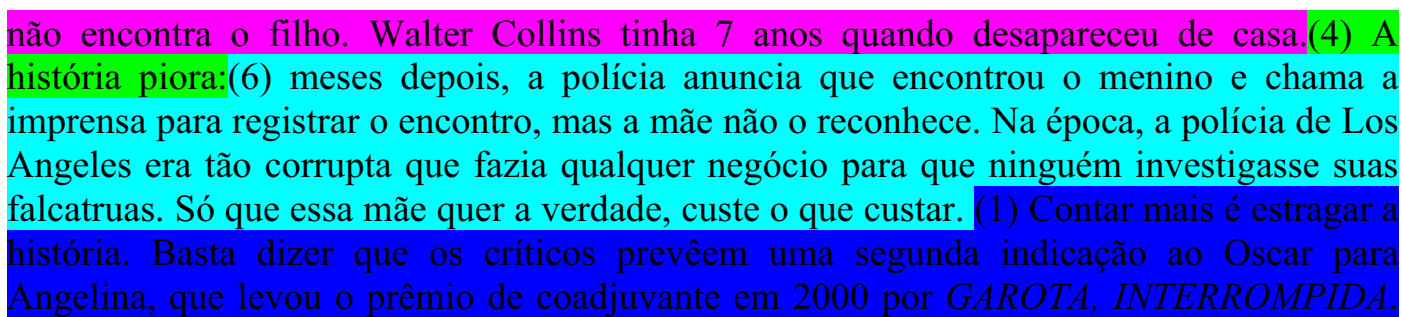

(2) A atriz conta que fazer $A$ TROCA teve para ela uma "função terapêutica", pois ajudoua a superar a dor da perda de sua mãe, Marcheline,

"Posso dizer que mais ou menos representei minha mãe nesse filme. É ela que vejo quando assisto ao filme, e Brad a vê também."

Neste caso, podemos perceber que os "planos inerciais" que compõem um dado texto não precisam ser em grande número. Como podemos ver nesta reportagem, os momentos mentais de referência vão se repetindo: (1), (2), (3), (2), (1), (4), (5), (4), (6), (1), (2), (1) e (3). Em outras palavras, os espaços mentais entendidos como Momentos de Referência num sentido mais lato se constroem um a um, e algumas vezes são retomados, ou "reacessados". No caso dessa reportagem, são utilizados apenas alguns (seis) espaços mentais, e, ao longo do texto, alguns deles são retomados. Podemos chamá-los, neste caso, de planos inerciais, porque precisamos ter a certeza de que, nessas parcelas de tempo, as pessoas estejam pressupondo as mesmas coordenadas espaço-temporais ${ }^{69}$.

- de centímetro a centímetro, podemos pensar no tempo de cada oração, formando os espaços mentais ${ }^{70}$, ou seja, as "cenas" mentais de cada evento;

- ou de milímetro a milímetro, pensando no tempo de cada expressão temporal que advérbios temporais, verbos, e alguns substantivos apresentam.

Um aspecto muito importante dessa teoria dos Espaços Mentais são os space builders (construtores de espaço). Os space builders nos ajudam a localizar espaços mentais particulares. Sua função é fazer com que um espaço mental seja aberto.

O advérbio amanhã em (1) Amanhã estudo Matemática é um space builder ( $s b)$ porque ajuda a construir um Espaço Mental: um MR enunciativo futuro. Esse espaço mental é o lugar onde cognitivamente se posiciona o sujeito no futuro, no qual, estando o sujeito

\footnotetext{
${ }^{69}$ Corôa (1998) também analisa um texto em suas partes referenciais de tempo. Divide-o, por exemplo, em tempos verbais, aplicando em textos uma interpretação simplificada de como os verbos flexionados funcionam como elementos de coesão temporal.

${ }^{70}$ Estamos explorando, a cada item, uma "forma" de espaço mental, partindo de uma forma maior para uma menor. Nesse item em que nos encontramos, identificamos aquele espaço que mais comumente se chama de "espaço mental", ou seja, uma pequena parcela de epaço-tempo capaz de formar uma "cena" que o falante passa a interiorizar.
} 
mentalmente em um "presente", conseguirá dizer com segurança qualquer enunciado. Em outras palavras, a coerência entre se usar um verbo morfologicamente indicando presente $($ estudo $=$ presente $)$, mas semanticamente indicando futuro (estudo $=$ estudarei) se baseia no fato de que "amanhã" constitui um space builder ${ }^{71}$, que faz com que o falante se projete num futuro, por meio de um mental space e, com isso, estando imaginariamente nesse espaço, utilizar um verbo no presente para "concordar" com a sua pretendida situação temporal dentro desse seu tempo futuro imaginário, ou seja, a situação de presente. Novamente integra-se por compressão o tempo presente a um tempo futuro.

Podemos dizer que esses Espaços Mentais são como Momentos de Referência: são como o palco de um teatro, ou o cenário de um filme, porque temos toda a situação temporal em que está ocorrendo o sistema inercial descrito, e é no MR que opera a atividade enunciativa por meio dos MFs. Passar de um cenário a outro é simples como atravessar uma porta, onde deixamos um cenário de um lado para entrar em um outro cenário. Essas "portas do tempo" funcionam como metáforas para o acessamento dos Espaços Mentais da Teoria Cognitiva.

Carlota Smith (1978, p.43-100 apud ILARI, 2002) constatou, em língua inglesa, que, nos períodos gramaticais em que o verbo regente é um verbo de dizer, o ME da oração regente (ou principal) coincide com o MR da oração subordinada de maneira regular e constante. E atribui a essa regularidade o nome de sharing principle, ou seja, princípio de compartilhamento. Concordamos com ela, pois achamos que o ME da oração principal, por ser um verbo de dizer, funciona como um space builder e por isso o que de fato ele irá construir são MRs.

Explorar mais detalhadamente quais são os construtores de espaços mentais da língua portuguesa seria uma tarefa muito interessante. Abreu (2010) nos explica que recentemente há uma tendência de se considerar como construtores de espaços na teoria cognitiva todo e qualquer elemento que seja responsável por ativar um espaço mental, o que pode incluir até mesmo efeitos prosódicos.

\footnotetext{
${ }^{71}$ Um dos space builders mais comumente usados, diz Fauconnier, são os advérbios de tempo.
} 


\section{4 - NÍVEL D) O conteúdo temporal do discurso no nível do enunciado}

Os estudos dos tempos verbais e de outras expressões de tempo em língua portuguesa ainda não encontraram um modelo formal que dê conta de descrever o encadeamento das noções temporais que aparecem ao longo de um texto. A linguagem precisa concatenar as diferentes manifestações de tempo, seguindo uma ordem na compreensão do discurso. À medida que o texto é maior, a complexidade na definição do tempo linguístico também

aumenta. É por esta razão que os falantes precisam sempre reestruturar o esquema temporal do discurso. A especificação do tempo na linguagem tem necessidade de vários níveis de interpretação que exigem uma sequenciação, que não é linear, no contínuo do discurso, mas que deixa marcas para que o leitor recomponha essa linearidade, não misturando, por exemplo, os tempos passados de uma narrativa.

À medida que um texto se alonga, somando vários enunciados, a noção de tempo precisa estar coerentemente encadeada. Enquanto vamos lendo um texto, vamos guardando na memória e encadeando as noções temporais mais relevantes, em uma coerência temporal. A coerência é caracterizada, entre outras coisas, como uma continuidade de sentidos perceptível no texto, resultando em uma conexão cognitiva entre os elementos de um texto $(\mathrm{KOCH}$; TRAVAGLIA, 1990).

Sabemos encadear temporalmente o tempo linguístico que está sempre em função de um tempo zero porque os domínios referenciais de tempo que temos se dão com a formação de planos inerciais (MRs,) que dependem do ponto de vista do falante real de um discurso. Pelo nosso conhecimento de mundo, sabemos ordenar os vários domínios de MRs ao mesmo tempo em que relacionamos a ordenação alcançada com o efeito criado entre o modo como os eventos foram narrados, uma vez que estes estão presos à linearidade linguística. Esse processo recursivo de concatenação ocorre o tempo todo e sem que o falante encontre problemas para o fazer, do ponto de vista da percepção. Esse processo de recursividade pode ser metaforizado pela mesma idéia das "portas do tempo" vista anteriormente, pois as "portas" funcionariam como as balizas responsáveis pela constituição de um espaço mental interlocutivo.

Nesta Dissertação, buscamos sistematizar apenas os modos como pode haver MEs em relação a MFs e estes em relação aos MRs, mas não fizemos a sistematização de como esses MEs se articulam e se concatenam por meio de outros termos da linguagem como 
principalmente os advérbios (é o caso dos termos já mencionados antes, depois, entre, etc.). Não conseguiríamos traçar um modelo esquemático para o nível do conteúdo temporal expressado pelos enunciados devido a sua complexidade. Basta imaginarmos uma grande história contada por meio de diversas possibilidades de uma programação textual (analepse, prolepse, etc. ${ }^{72}$ ). Na compreensão desse discurso, é necessário conceber a história de forma não cronológica. Após a leitura, entretanto, o que se tem é a história cronológica na memória, pois é muito difícil recontarmos a mesma história na forma como ela foi escrita. É como o montar de um quebra-cabeça: começa-se com uma grande confusão e termina-se com uma figura completada; se quisermos relembrar a ordem em que as peças foram montadas, teremos uma tarefa muito difícil.

\footnotetext{
${ }^{72} C f$. REIS; LOPES, 1988.
} 


\section{Capítulo 5 - O ESQUEMA DO TEMPO}

\section{1 - O tempo da linguagem}

Há uma grande diferença de ordem temporal entre o tempo do discurso e o tempo da linguagem: “[...] o momento da enunciação [enunciada] pode ser colocado em qualquer divisão do tempo cronológico [...]” (FIORIN, 2003, p.166), já a enunciação, enquanto ato de produção/recepção, não pode ser "localizada" em qualquer divisão do tempo cronológico, porque ela é intrínseca ao mundo real e não ao mundo criado pela linguagem (o discurso). Somente pela abstração do tempo presente real, poderemos determinar, de alguma forma (segundo, hora, dia, ano, etc.), em que momento se dá o tempo da linguagem (ato da enunciação).

Como o momento da enunciação enunciada pode ser colocado em qualquer divisão do tempo cronológico, podemos ter uma enunciação no futuro, no passado ou no presente, e cada uma delas poderá ter a intenção de estar temporalmente afastada - enuncivo - ou próxima enunciativo - do momento da enunciação. O momento da enunciação é, então, sempre presente, e este presente será sempre o presente de acordo com cada individuo que enuncia.

O falante, ao enunciar, precisa levar em consideração o seu presente cronológico para estabelecer as questões lógicas entre o discurso e a realidade. Sabemos que o discurso possui sua própria cronologia, mas para saber se essa nova cronologia linguística é anterior, posterior ou concomitante, é preciso saber em que tempo real estamos produzindo/recebendo o enunciado. Parece isso tudo um pouco óbvio, mas não podemos, por causa disso, deixar de fazer essas considerações.

Por meio de investigações sobre qual é o sistema temporal da língua portuguesa, chegamos a um esquema básico da manifestação do tempo, ou seja, de uma sistematização das possibilidades do tempo em um esquema visual. Tentaremos neste capítulo sistematizar nossas considerações feitas até agora.

Há duas grandes naturezas de tempo a serem observadas pelo linguista: o tempo da linguagem (time) e o tempo da língua (tense). Ao tempo da linguagem (time) pertencem as linhas do "tempo real" e do "tempo da enunciação pressuposta". Ao tempo da língua (tense) pertencem as linhas do "tempo enunciativo" e do "tempo enuncivo"; neste tipo de tempo (tense) as relações de presente, passado e futuro se dão por referências gramaticais e contextuais. O momento da enunciação extralinguística será sempre anterior a qualquer 
enunciação enunciada, por menor que seja o intervalo temporal entre a intenção de enunciado e a sua enunciação. A enunciação, embora seja considerada um ato presente, precisou de alguns instantes para ser realizada porque todo ato exige tempo e toda consciência perceptiva de algo que se pretende enunciar também. Por exemplo: para dizermos $A$ casa é amarela, no mesmo momento em que observamos uma casa amarela, nossa percepção sobre uma casa de cor amarela, por mais rápida que tenha sido, ocorreu antes de podermos enunciar que a casa era amarela. Por outro lado, o tempo de reação é de uma magnitude geralmente desprezível, e pode ser desconsiderada sem prejuízo.

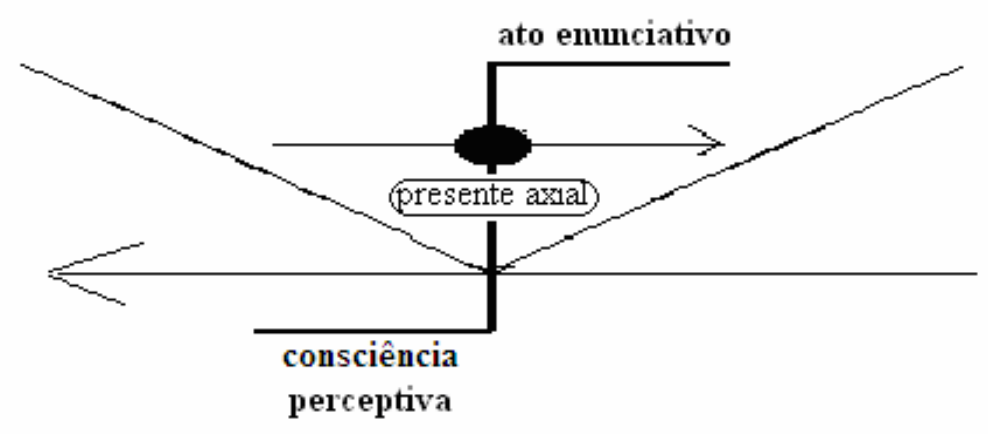

Figura 60 - A anterioridade da consciência perceptiva e a posterioridade do produto do ato enunciativo

Nessa ilustração do tempo da linguagem, o tempo real está em algum lugar imediatamente anterior ao presente enunciativo. O presente axial se encontra na seta subjetiva do tempo do homem, que se liga à seta objetiva do tempo do mundo.

\section{2 - O tempo do discurso}

Benveniste (2006) nos diz que a singularidade do tempo linguístico consiste no tempo ser ligado ao exercício da fala. Quando o falante toma a palavra, instaura um agora (momento da enunciação). Podemos dizer que esse agora físico se transforma semanticamente em um "agora agora" ou em um "agora então", porque o discurso terá uma intenção ou de aproximar ou distanciar os interlocutores. Esses novos tempos concomitantes não serão mais 
necessariamente "presentes", como é o Momento do ato da Enunciação, uma vez que poderão ser também passados e futuros. O importante não é ser um "presente", mas possuir um ponto zero lógico dentro de um sistema referencial (MR), que será relativamente concomitante ao momento da enunciação pressuposta.

Como vimos, o tempo cronológico pode ser "experimentado" de duas formas distintas: ora nos lembramos em que momento estamos, mantendo relações de presente passado e futuro no tempo, ora nos deixamos levar pelo tempo, sem que nos atentemos a sua passagem. Podemos dizer que, semanticamente, a linha cronológica do discurso pode, a semelhança do tempo real, também ser "experienciada" de duas formas distintas: ora nossa atenção se volta subjetivamente às relações de passado presente e futuro no tempo, ora somos levados "objetivamente" pelo texto, não nos comprometendo com a temporalidade do ato de comunicação.

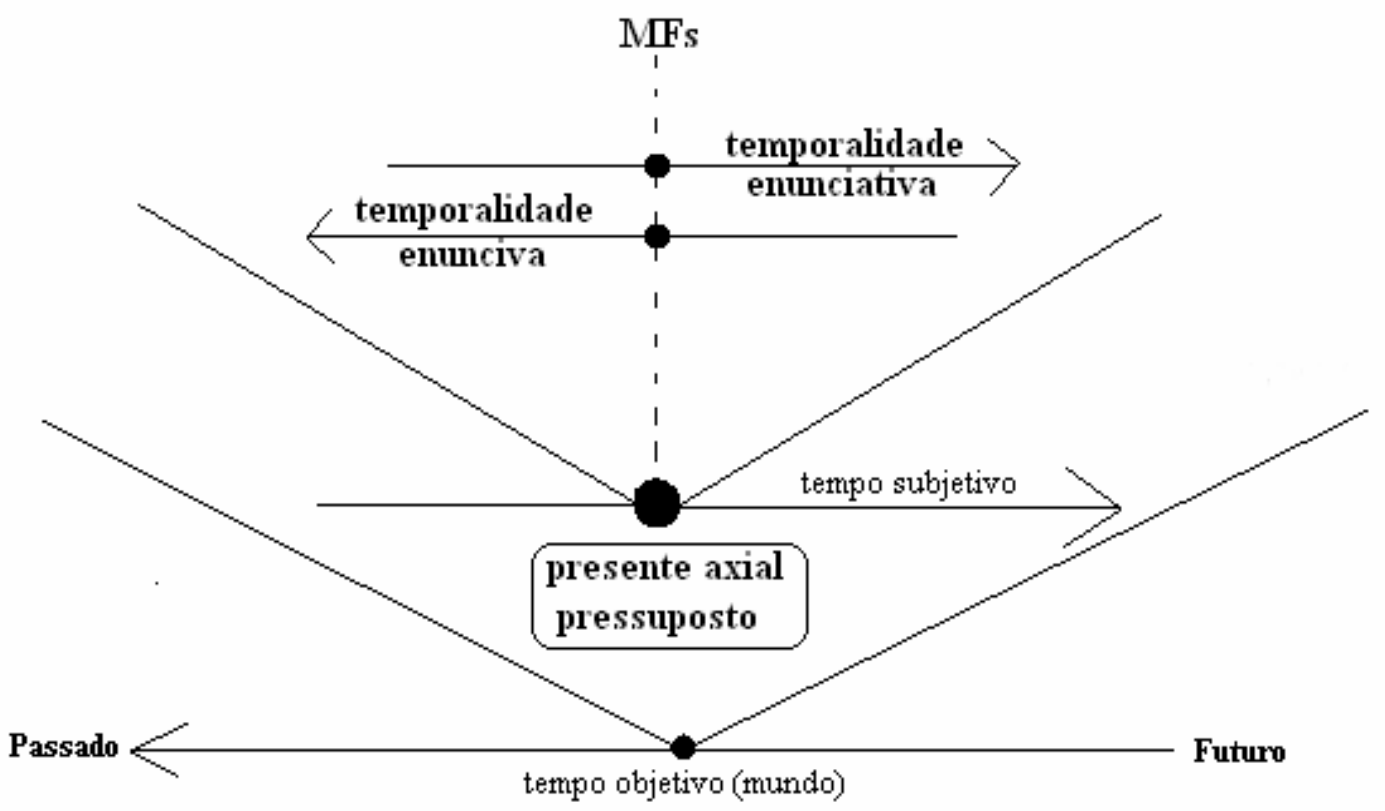

Figura 61 - O encadeamento do presente cronológico individual ao presente pressuposto, e este ao MF agora ou ao MF então.

Em cada uma das duas temporalidades (mundo comentado e mundo narrado), há três sistemas de referência (passado, presente e futuro) descritos na figura abaixo (figura 62). Como vimos na subseção 4.3.3, além das três tradicionais referências do discurso, tentamos defender três outras referências lógicas: um tempo presente do mundo narrado, e um tempo passado e um tempo futuro do mundo comentado. Estes últimos se dariam por meio de uma dêixis fictiva. 


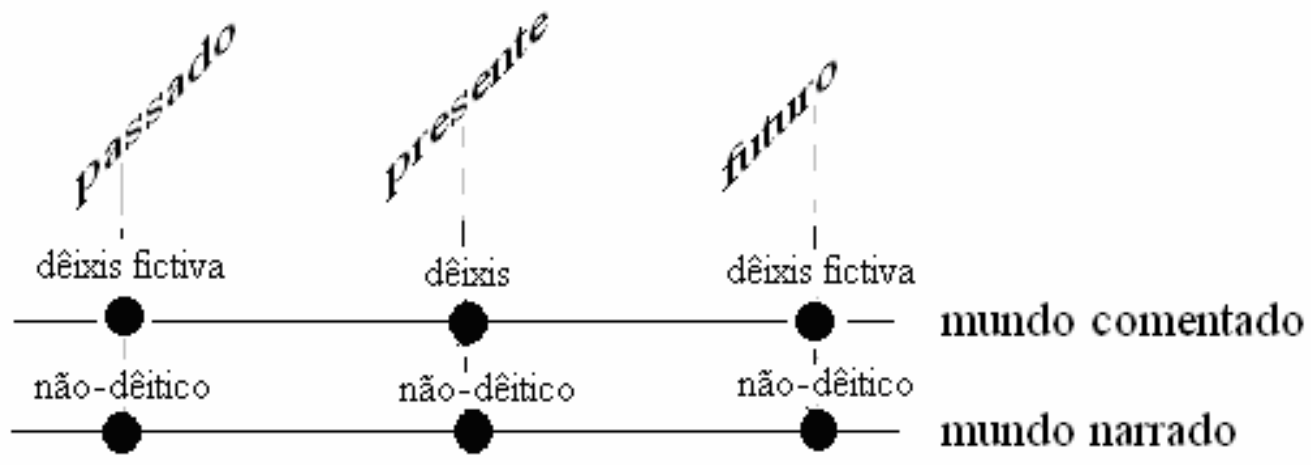

Figura 62 - Os seis Momentos de Referência (MR)

Nesta figura, cada ponto corresponde ao sistema de referências (MRs), e dentro deles há o ponto zero lógico do MF, ao qual os MEs irão se dispor.

Pela ilustração 62, podemos dispor, por exemplo, o tempo da forma verbal pegou, como exemplo de um pretérito perfeito. Essa forma modotemporal, dependendo do contexto, pode equivaler temporalmente ao passado de um MR presente (figura 63), ou ao presente de um MR passado (figura 64):

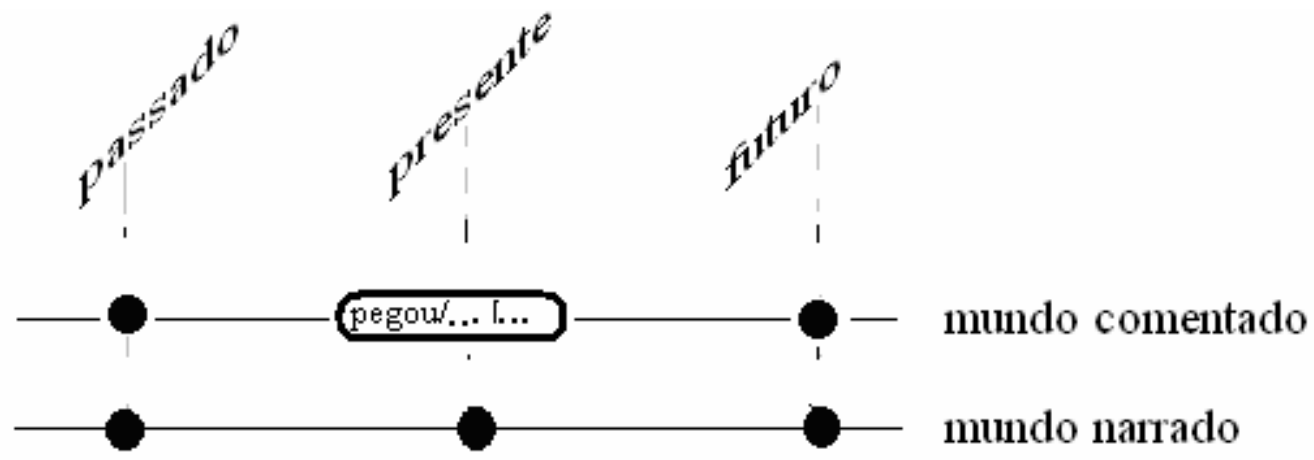

Figura 63 - Localização do pretérito perfeito 1

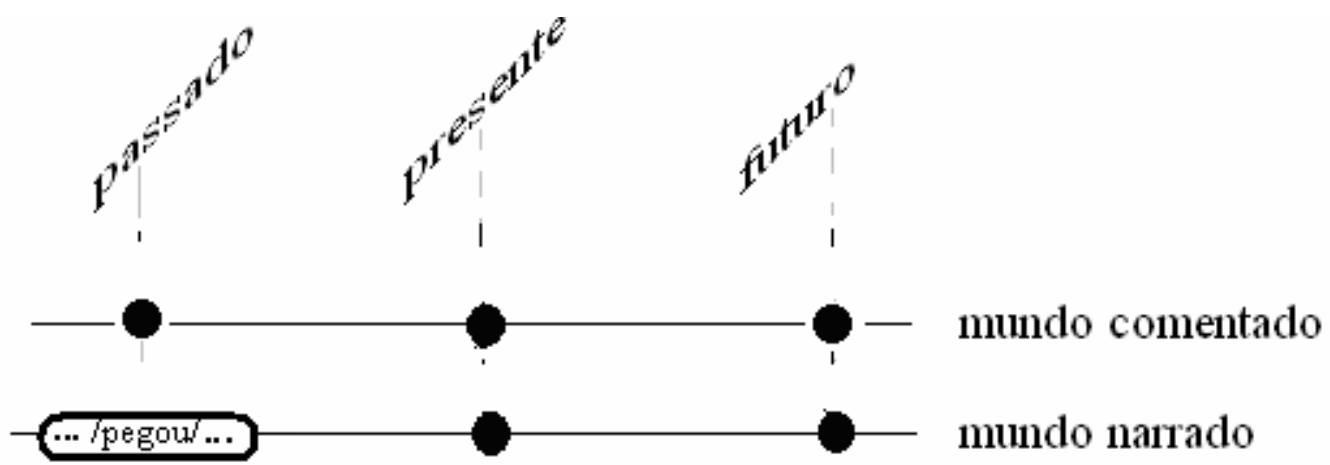

Figura 64 - Localização do pretérito perfeito 2 
Essas duas últimas figuras mostram como podemos indicar o lugar onde se estabelece um determinado pretérito perfeito: em qual sistema de referência MR e em qual lugar lógico ele pode se estabelecer pelo MF, ou seja, se concomitante (figura 63) ou anterior (figura 64).

\section{3 - Descrevendo com fórmulas lineares}

Corôa (1998) ilustra os construtos reichenbachianos com formas geométricas:

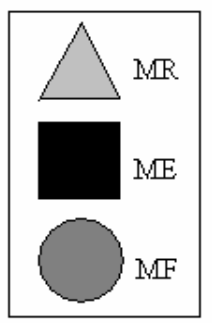

Figura 65 - Ilustração de Corôa (1998) para os construtos de Reichenbach.

De forma planificada (e, por isso, não linear), os construtos são dispostos em dois “eixos" horizontais: o MR acima e o ME e MF num eixo abaixo. O "plano" em questão é formado pela ligação entre os limites das formas geométricas abaixo, por exemplo:

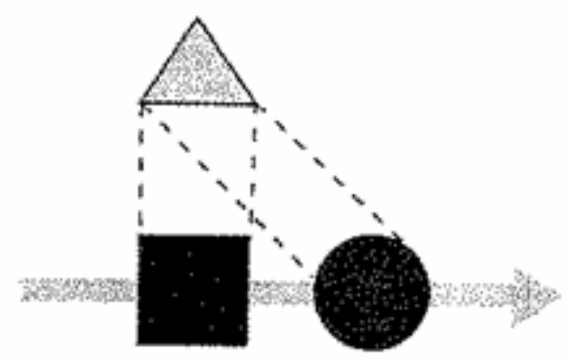

Figura 66 - Exemplo de disposição dos construtos ilustrativos (CORÔA, 1998, 111)

Como se percebe na figura 66, o eixo de MF e ME é representado por uma "flecha" unidirecional.

Segundo Corôa (1998, p.86), o MR é “[...] o tempo da referência, como o 'intervalo' de tempo relevante para a consideração do ato verbal, a perspectiva que transita entre os interlocutores no ato da comunicação." (CORÔA, 1998, p.86). A linguista vê a necessidade do alargamento desse intervalo conforme a relevância do tempo empregado. 
Acreditamos que também podemos pensar os construtos separando-se o MR da relação ME/MF. Uma vez que apenas os verbos (objeto principal da descrição de Reichenbach) não são capazes de indicar a noção de tempo total de um enunciado, o ME ganha vários sentidos pela combinação variada que ele pode fazer com o MR. Como viemos tentando encontrar "lugares" gerais para o tempo (e encontramos seis), precisamos, por meio dos construtos de Reichenbach, fazer cálculos temporais em duas etapas: na primeira, localiza-se o MR; na segunda, o ME dentro desse sistema referencial. A nova proposta contaria, assim, com uma "dupla linearidade" (e não com um único plano).

Por exemplo, enquanto no caso do pretérito imperfeito a fórmula tradicional de Reichenbach é ME,MR - MF, porque a referência indica que a perspectiva recai sobre o evento, diremos que, na verdade, essa é uma característica de todos os enunciados do mundo narrado, ou seja, a referência se liga ao que se fala (ME) e não a quem diz (MF). Mas, como vimos, o enunciado considerado como um todo (somando-se todas as informações trazidas não só pelos verbos) se dá em um espaço mental MR. Por esse motivo, a nossa fórmula mostra a relação $\mathrm{ME} / \mathrm{MF}$ formando, com o uso de parênteses, um bloco, e este bloco irá inteiramente se situar em um determinado MR. Há, portanto, duas equações a serem feitas, procurando-se identificar:

- $\quad$ se MR é passado, futuro ou presente;

- se ME é passado (anterior), futuro (posterior) ou presente (concomitante) em relação a MF.

Mas falta ainda estabelecer uma condição:

- Se o enunciado mantém uma relação tensa ou "distensa" com o MF.

Devemos ter sempre como pressuposto que o MR irá representar uma tensão (aproximação com o MF) ou distensão (aproximando-se do momento dos eventos) com relação à instância da enunciação. Neste último caso, cria-se um mundo anterior (como vimos na figura 14) ao momento em que o texto é comunicado. O interlocutor é "convidado" a se afastar da perspectiva de tempo atual e a acompanhar os acontecimentos como se eles se desenrolassem por si mesmos.

Enquanto Reichenbach fez uma descrição unidirecionada com os seus construtos, nós percebemos que, com o uso de conceitos discursivos que subdividem o sistema temporal da língua em duas grandes referências temporais (narrado vs comentado), a noção de Momento de Referência necessitava de uma descrição bidirecionada.

Como vimos, Reichenbach utiliza uma única linha do tempo e pode demonstrar formalmente os construtos linearmente, ou seja, os seus três construtos podem ser descritos de 
modo que fiquem dispostos em uma linha. Mas a natureza do MR é diferente da natureza do ME e MF. O ME e MF são de um sistema da enunciação enunciada, e o MR é do sistema cronológico atualizado cognitivamente, e depende de um referencial semântico.

Nós também faremos, agora, uma demonstração formal linear, desde que sejam feitas algumas condições para isso:

- cada um dos seis MRs possui um centro lógico que será o MF, portanto todo MF está operacionalmente concomitante ao MR; cada MF (seja enunciativo seja enuncivo) se comunica concomitantemente com o presente pressuposto da enunciação. $\mathrm{O} M F$ é o centro lógico de $\mathrm{MR}$, isso significa que os dois são concomitantes. Entretanto, essa relação de concomitância não foi marcada por defasagem do nosso suporte descritivo - a linearidade; esta é uma condição que deve ser sempre pressuposta;

- os MRs do tipo enuncivo possuem seus centros lógicos de MFs que, embora sejam concomitantes ao momento da enunciação pressuposta, estão "afastados" deste, porque querem apresentar um caráter objetivo. Os MRs do tipo enunciativo possuem seus centros lógicos de MFs que, além de concomitantes ao momento da enunciação, estão "próximos" deste, porque querem apresentar um caráter subjetivo;

- o MR na nossa seguinte forma de descrever o tempo será marcado em relação à fórmula (MF/ME), para se saber em que local temporal, numa linha cronológica imaginária, o MR se localiza. Assim, MR - (MF/ME) indica um MR pretérito, MR,(MF,ME), um MR presente, e (MF/ME) - MR, um MR futuro. 
Quadro 16. O mundo comentado descrito com três construtos

\begin{tabular}{|c|c|c|}
\hline $\begin{array}{l}\text { Lugares } \\
\text { temporais }\end{array}$ & $\begin{array}{l}\text { Fórmulas de Reichenbach } \\
\text { realizáveis em lingua portuguesa }\end{array}$ & $\begin{array}{l}\text { Nossa proposta } \\
\text { Mundo Comentado (MR enunciativo) }\end{array}$ \\
\hline Passado & $\begin{array}{l}-- \\
-- \\
--\end{array}$ & $\begin{array}{l}M R-(M E-M F) \\
M R-(M E, M F) \\
M R-(M F-M E)\end{array}$ \\
\hline Futuro & $\begin{array}{l}-- \\
-- \\
--\end{array}$ & $\begin{array}{l}(\mathrm{ME}-\mathrm{MF})-\mathrm{MR} \\
(\mathrm{ME}, \mathrm{MF})-\mathrm{MR} \\
(\mathrm{MF}-\mathrm{ME})-\mathrm{MR}\end{array}$ \\
\hline Presente & $\begin{array}{l}\mathrm{ME}-\mathrm{MR}, \mathrm{MF} \\
\mathrm{MR}, \mathrm{MF}, \mathrm{ME} \\
\mathrm{MR}, \mathrm{MF}-\mathrm{ME}\end{array}$ & $\begin{array}{l}\text { (ME - MF),MR } \\
(\mathrm{ME}, \mathrm{MF}), \mathrm{MR} \\
(\mathrm{MF}-\mathrm{ME}), \mathrm{MR}\end{array}$ \\
\hline
\end{tabular}

Quadro 17. O mundo narrado descrito com três construtos

\begin{tabular}{|c|c|c|}
\hline $\begin{array}{l}\text { Lugares } \\
\text { temporais }\end{array}$ & $\begin{array}{l}\text { Fórmulas de Reichenbach } \\
\text { realizáveis em lingua portuguesa }\end{array}$ & $\begin{array}{l}\text { Nossa proposta } \\
\text { Mundo Narrado (MR enuncivo) }\end{array}$ \\
\hline Passado & $\begin{array}{l}\mathrm{ME}-\mathrm{MR}-\mathrm{MF} \\
\mathrm{ME}, \mathrm{MR}-\mathrm{MF} \\
\mathrm{MR}-\mathrm{MF}-\mathrm{ME}\end{array}$ & $\begin{array}{l}M R-(M E-M F) \\
M R-(M E, M F) \\
M R-(M F-M E)\end{array}$ \\
\hline Futuro & MR,MF - ME & $\begin{array}{l}(\mathrm{ME}-\mathrm{MF})-\mathrm{MR} \\
(\mathrm{ME}, \mathrm{MF})-\mathrm{MR} \\
(\mathrm{MF}-\mathrm{ME})-\mathrm{MR}\end{array}$ \\
\hline Presente & $\begin{array}{l}- \\
- \\
--\end{array}$ & $\begin{array}{l}\text { (ME - MF),MR } \\
\text { (ME,MF),MR } \\
(\mathrm{MF}-\mathrm{ME}), \mathrm{MR}\end{array}$ \\
\hline
\end{tabular}

São fórmulas de anterioridade, concomitância e posterioridade aplicadas ao passado enunciativo e enuncivo, ao futuro enunciativo e enuncivo e ao presente enunciativo e enuncivo. O quadro 16 possui as fórmulas que pertencem a um mundo comentado (sistema enunciativo), e o quadro 17 possui as fórmulas que pertencem a um mundo narrado (sistema enuncivo). Formalmente, as colunas de construtos da direita são idênticas nos dois quadros. A diferença consiste em que o Momento da Fala enunciativo representa um agora e o Momento da Fala enuncivo representa um então, e este pede um "afastamento discursivo" do momento 
da enunciação quanto à atitude estabelecida entre os interlocutores, embora seja concomitante ao ato de enunciar responsável pelo funcionamento da língua.

Dentre as treze fórmulas possíveis de Reichenbach, reproduzimos, nos quadros acima, apenas as fórmulas realizáveis em língua portuguesa. Dentre as nossas fórmulas, devemos dizer que são todas as possíveis (e por isso preenchem todo o quadro), pois nos faltou oportunidade para verificar com mais cuidado quais dessas fórmulas são realizáveis em língua portuguesa.

Conforme a distinção proposta por Corôa (1998) entre temporalização e temporalidade, podemos dizer que tentamos prever uma formalização, com os construtos de Reichenbach - juntamente com a condição de interpretarmos o MR com duas atitudes -, de uma possível descrição da temporalidade da linguagem. A temporalização poderá ser objeto de um outro trabalho. Isto porque a temporalização é o conjunto de relações marcadas linguisticamente, em uma determinada língua, e que revela uma temporalidade. Em outras palavras, procurou-se fazer mais um exercício de entender a temporalidade do que identificar todas as marcas da temporalização.

O conceito de temporalidade não está apenas na informação gramatical do texto, mas também está na relação que o falante estabelece entre seu discurso e o seu tempo particular no mundo, como pudemos perceber ilustrativamente, por exemplo, nas figuras 12, 13, 15, 27, 60 e 61, em que o ponto que toca a linha do tempo objetivo representa a inserção de um falante real. "Em outras palavras, o sujeito, na sua dimensão temporal, caracteriza-se por constituir e ser constituído na temporalidade que se tece na linguagem e se 'mostra' na temporalização.” (CORÔA, 1998, p.4173).

Nos quadros acima, não fizemos um mapeamento de todas as expressões linguísticas do tempo, mas tentamos deduzir em linhas gerais quais as referências possíveis de tempo, mesmo que não saibamos, num primeiro momento, quais são as atualizáveis em língua portuguesa $^{74}$. Colocamos o que entendemos como possibilidades, mas muito provavelmente nem todas as fórmulas podem ser atualizadas.

[...] a língua 'sedimenta' histórico-culturalmente as distinções que se tornam relevantes, e nem todas as possibilidades combinatórias precisam ser realizadas; muito menos realizadas pelas mesmas categorias lingüísticas ou

\footnotetext{
${ }^{73}$ Parret propôs um conceito de temporalização, que seria a temporalidade tratada de um ponto de vista do ego, hic, nunc. (PARRET, 1988, p.191)

${ }^{74}$ Como vimos, a ocorrência da totalidade de combinações matematicamente possíveis entre os construtos de Reichenbach não foi constatada em uma língua.
} 
gramaticais. A grande diversidade das línguas nesse campo serve de comprovação. (CORÔA, 1998, p.247-248).

A seguir, escolhemos apenas alguns exemplos para ilustrar o que ocorre dentro desses lugares mentais, descritos como seis Momentos de Referência (MR), conforme os seus seis tipos de MFs.

Para a construção de um modelo de natureza linguística, utilizaremos duas séries temporais para dispor os construtos de Reichenbach: uma linha de natureza cronológica, que se refira a um mundo em que se criam os espaços mentais, e uma linha enunciativa. Sobre a linha do tempo enunciativa, devemos marcar um ponto central que corresponda ao momento da fala (que se identifica concomitantemente ao momento da enunciação enunciada). Em relação a ele é que o tempo dos verbos irá se localizar (os MEs). "Para Pontes (1972: 75), a categoria gramatical de tempo 'marca $[\ldots]$ o tempo $[. .$.$] da ocorrência do processo verbal em$ relação ao momento da fala'[...]" (CORÔA, p.34, 1985).

Corôa (1998) compara o sistema temporal do português a um conjunto de planos formados pelos construtos do MR, MF e ME, não sequencialmente alinhados. Como se trata de um plano, a proposta de Corôa não ilustra a nossa intuição de que o tempo possui uma única dimensão, ou seja, a nossa conhecida metáfora da linha do tempo. De acordo com nossa proposta, diríamos que o tempo é duplamente linear. Ou seja, a nossa intuição da unidimensionalidade ainda é valida na nossa descrição do tempo.

No caso do presente histórico, Cunha e Cintra (1985, p.438) dizem que "imaginamonos no passado, visualizando os fatos que descrevemos ou narramos". O modo com o qual conseguimos nos imaginar em um outro tempo se dá estabelecendo um Momento de Referência por meio de uma orientação de ordem cronológica. É aqui que a teoria cognitiva poderia nos ajudar a ver como a mente cria um campo referencial. Vamos esquematizar o exemplo (88) com o uso de duas linhas temporais:

(88) Em 1808, a família real foge para o Brasil.

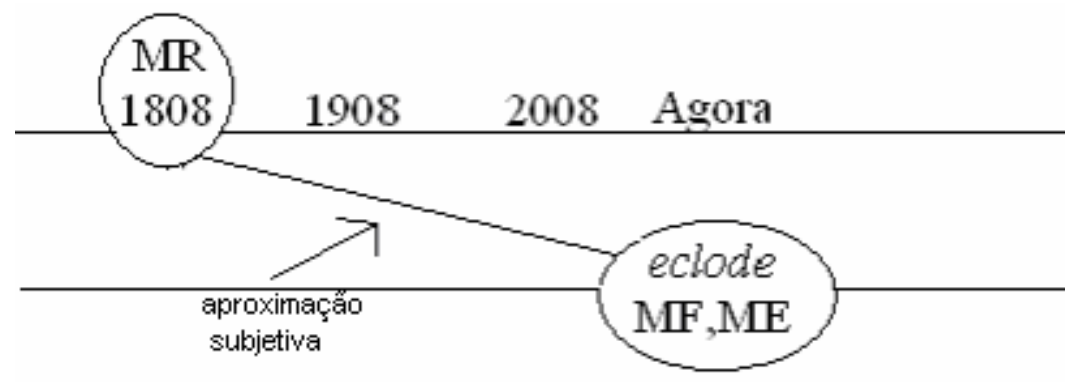

Figura 67 - O presente histórico 
Se tivermos como pressuposto que o texto não foi escrito em 1808, percebemos que o plano inercial de (88) está no passado; gramaticalmente é presente porque a fala condiz com o evento.

Ainda sobre o presente histórico, é comum encontrarmos explicações que dizem que o falante se transporta psicologicamente para o passado e "vê" o evento como seu contemporâneo. Para nós, neste caso (88) de presente histórico ${ }^{75}$, devemos construir um momento de referência no passado, além disso, a intenção subjetiva do enunciador pede para que nós mantenhamos uma relação de aproximação com o MF daquele enunciado. Estamos cognitivamente em algum lugar do passado na linha do tempo, mas estamos ligados subjetivamente a um presente real enunciativo.

O sistema de inércia (MR) é o responsável pelas variações. Ele é usado como referencial para MF.

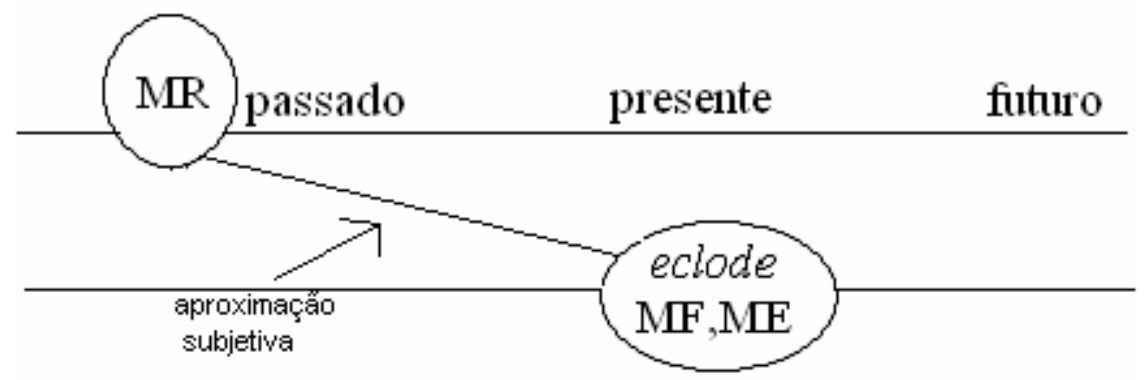

Figura 68 - O presente histórico com indicação, na linha do MR, de passado, presente e futuro.

Com essa outra ilustração do presente histórico, podemos identificar uma fórmula linear: [MR - (MF,ME)]. Esta fórmula, considerada sem os seus parênteses, é prevista como uma dentre as treze possibilidades matemáticas criadas por Reichenbach ( $c f$. quadro 5), mas não é utilizada como uma possibilidade possível da língua. $\mathrm{Na}$ verdade, a fórmula de Reichenbach [MR - MF,ME] não apresenta o elemento dos parênteses para marcar um bloco de MF e ME, como fizemos para distinguir o que é de um momento enunciativo (ME e MF) do que é de um momento cognitivo (MR).

Vejamos outro exemplo:

(89) Bateu, levou. (= Se me bater, irei bater em você também)

\footnotetext{
${ }^{75} C f$. nota 49 .
} 
Se pudermos explicar este exemplo de forma parecida com a explicação que os gramáticos fazem sobre o presente histórico, teríamos a afirmação de que o falante se transporta psicologicamente para o futuro e lá imagina a ação de bater já passada. Diremos, então, que o MR, implícito na situação toda de comunicação, estabiliza um sistema inercial no futuro: [(ME - MF) - MR]. Esta fórmula, considerada sem os parênteses, também é prevista pelas treze possibilidades em Reichenbach ( $c f$. quadro 5), na forma de [ME - MF - MR], mas esta não é reconhecida como uma possibilidade realizável.

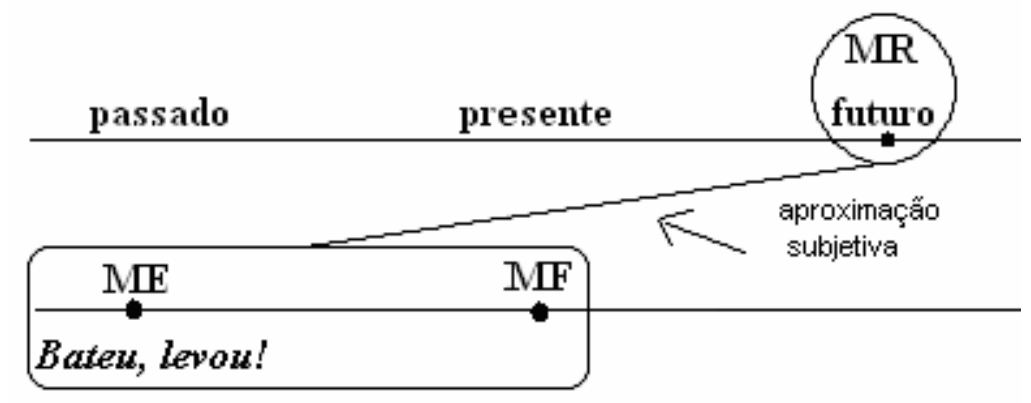

Figura 69 - O passado enunciativo no MR futuro

Ilari (2001, p.24), quando traz o exemplo Amanhã eu estudo isso, nomeia de presente futuro aquilo que chamamos de presente enunciativo com MR futuro, explicando que o fato por ocorrer passa a ser visto como certo. Vamos esquematizar um exemplo nosso:

(90) Estou viajando amanhã para São Paulo.

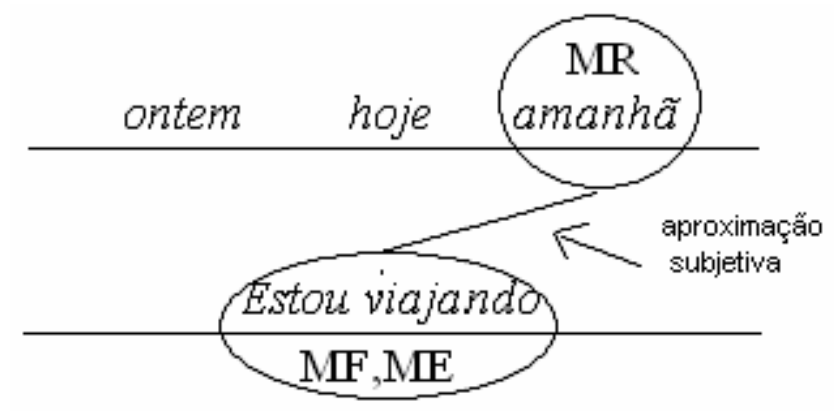

Figura $70-\mathrm{O}$ presente enunciativo no MR futuro

Sua fórmula [(MF,ME) - MR] também é prevista como uma dentre as treze possibilidades matemáticas criadas por Reichenbach ( $c f$. quadro 5), mas não é utilizada como uma possibilidade possível da língua. A fórmula ilustra que nos projetamos em algum lugar do futuro ([ - MR]). Entretanto, como o enunciado é subjetivo, há uma relação de tensão entre os interlocutores o que revela uma "aproximação" enunciativa entre MR e MF. 
Esses fatos temporais provam a natureza intersubjetiva do discurso, pois, do contrário, se o sujeito, ao fazer esses transportes de tempo, não tivesse a certeza de que o seu interlocutor os aceitaria e os adotaria como seus, o tempo linguístico não "funcionaria".

No exemplo anterior, o MF corresponde enunciativamente ao momento da enunciação enunciada. Isto acontece porque o enunciado pertence a um mundo comentado. Isto significa que a questão do mundo comentado vs mundo narrado é determinante na relação entre a "aproximação" ou o "afastamento" de MF (e consequentemente de MR) em relação ao momento da enunciação enunciada.

As fórmulas vistas em 88,89 e 90 pertencem ao primeiro quadro porque são de exemplos do mundo comentado (quadro 16). Para ilustrar a relação entre MR e MF/ME de um enunciado do mundo narrado, vejamos o seguinte exemplo:

(91) Flávio viajaria mais cedo naquele dia.

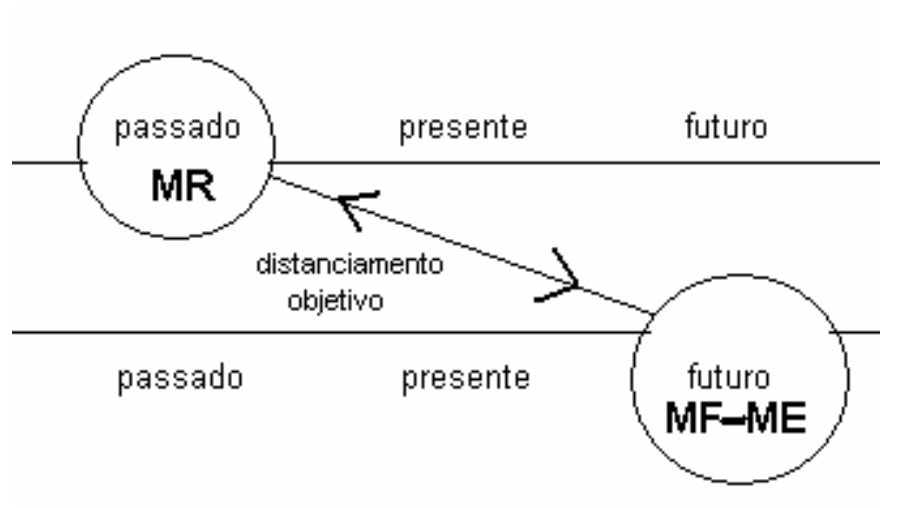

Considerando-se esse exemplo um enunciado enuncivo temporalmente, a sua fórmula seria [MR - (MF-ME)], e, além disso, deve se ter claro que a relação entre o momento da fala (MF) e a situação descrita (MR) deve ser de uma ilusão de independência da instância da enunciação, por estar numa atitude distanciada.

Vejamos mais alguns exemplos:

(92) Neste momento eu escrevo.

(93) Desde os cinco anos eu escrevo.

(94) Esta semana eu escrevo.

Nos enunciados (92), (93) e (94), os adjuntos orientam o MR. Vejamos um outro exemplo: 
(95) A terra gira em torno do Sol.

Neste exemplo (95), tradicionalmente classificado como presente "omnitemporal", ou "gnômico", com valor de enfatizar "verdades eternas", percebemos que o ME corresponde ao centro do sistema referencial, ou seja, ao $\mathrm{MF}^{76}$. Mas, o sistema fixo de referência é muito lato, quase infinito $^{77}$. É um MR que nos alerta que a informação do ME em relação ao MF foi válida tanto "para antes" quanto será "para depois" - mas ainda em um dado limite que nos permita dizer que é uma afirmação válida para o presente - uma vez que "[...] o momento de referência pode ser estendido ou diminuído segundo a situação [...]”' (CORÔA, 1985, p.47).

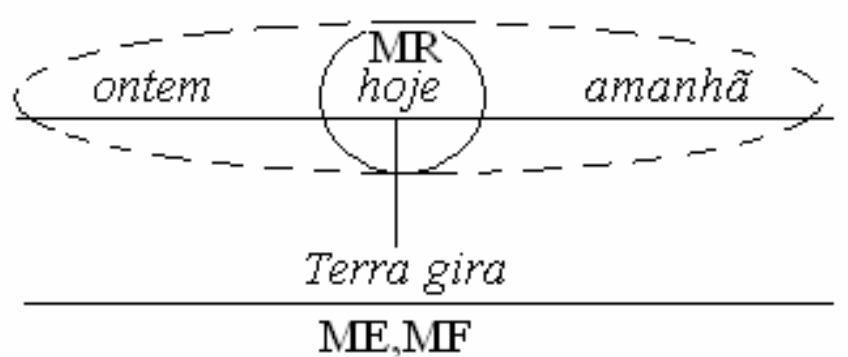

Figura 71 - Presente omnitemporal

Corôa (1998) estudou os intervalos de tempo relevantes na comunicação, demonstrando, ilustrativamente, quais os limites dos intervalos de tempo (entendidos como o comprimento de cada figura geométrica) de cada construto. Por exemplo:

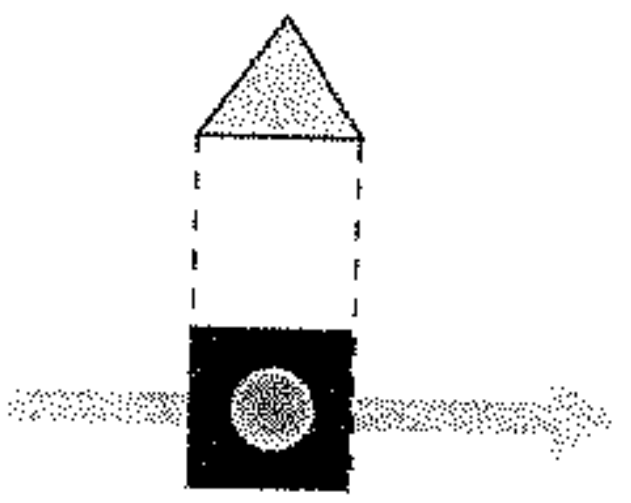

Figura 72 - Os limites de tempo nos construtos em Corôa (1998)

\footnotetext{
${ }^{76}$ A ideia de que existiriam expressões linguísticas "fora do tempo" ou de "não-tempo" nos casos de presente histórico, presente gnômico e provérbios, por exemplo, não encontrou lugar nessa Dissertação. Nós procuramos defender que o falante tem necessidade, o tempo todo, de fazer a localização temporal dos enunciados em uma linha do tempo.

${ }^{77}$ Sobre essa abrangência referencial dos construtos, $c f$. CORÔA (1998).
} 
Nesta figura, com a qual Corôa ilustra o presente habitual, os intervalos de tempo para MR e ME são mais amplos do que para MF, demonstrando-se que a abrangência da afirmação de ME se estende em um tempo maior que o momento presente da fala.

Nós, entretanto, não nos preocupamos em mostrar a abrangência (essa espécie de aspectualidade) dos intervalos de tempo. Nos preocupamos em mostrar o lugar temporal em que se localizam esses intervalos de tempo. Isto porque o limite do nosso MR não é definível em relação ao MF e ME; o nosso MR é um lugar mental de tempo.

É o nosso conhecimento de mundo e nossa cultura os primeiros responsáveis pela "montagem" desse sistema fixo de referência - o MR.

Embora a ilustração que acabamos de fazer seja formada por duas linhas do tempo, isso não significa que nossa compreensão do tempo seja assim tão complexa. Podemos dizer que nosso sistema do tempo se dá em etapas: primeiro, cognitivamente, organiza-se cronologicamente a referência ao sistema que será utilizado; depois organiza-se a linha gramatical, para se entender onde é o centro lógico, o MF, e onde o ME está localizado em relação ao MF. "Jespersen (1958) admite que somos obrigados - pela essência do tempo ou pela necessidade do nosso pensamento - a imaginar o tempo como uma dimensão: pode, portanto, ser representado por uma linha reta [...]” (CORÔA, 1985, p.25). 


\section{Capítulo 6 - CONCLUSÃO}

Na nossa revisão geral sobre a concepção do tempo real, vimos que o tempo foi objeto de incansáveis indagações pelos físicos e pelos filósofos. Dada a complexidade desse objeto, observou-se que definir o tempo é defini-lo de acordo com determinada religião, posição filosófica, ou teoria científica, embora estejamos sempre nos referindo ao mesmo objetotempo. Mesmo com as revoluções tecnológicas do mundo contemporâneo, ainda é impossível definir com certeza o que seja o tempo.

De um ponto de vista comum à maioria das pessoas, tentamos descrever o movimento do tempo por uma "linha", por esta ser a metáfora mais intuitiva desse tempo unidimensional interpretável pelo ser humano. Distinguindo-se a ação do tempo na natureza (tempo objetivo) e a ação responsável pela captação do tempo operacional da mente humana (tempo subjetivo), montamos uma ilustração (figura 12) do tempo do mundo, com basicamente duas setas do tempo de direções contrárias.

Quando investigamos o tempo da linguagem, percebemos que o ato de gerar discursos se realiza em um tempo real do mundo que não deve ser desprezado. No momento da enunciação, acontece a projeção de dois grandes mundos possíveis: o narrado e o comentado, caracterizados, respectivamente, por representarem uma temporalidade "das coisas" e uma temporalidade "do dizer". Esses mundos são inspirados nos tempos de récite e commentaire de Weinrich (1968). Vimos que essas temporalidades podem ser representadas também por direções no tempo: o tempo do mundo comentado pode ser "sentido" como uma continuidade operacional do tempo, e o tempo do mundo narrado pode ser "sentido" como se observássemos a natureza das coisas "passando" por nós.

Essas direções se mostraram simétricas às setas que encontramos para a descrição do tempo do mundo. A percepção física do tempo (continuidade, descontinuidade) se assemelha à sensação estabelecida na comunicação (tensa, distensa). A simetria encontrada na ilustração descritiva do tempo criado pela linguagem otimizou as teorias analisadas e motivou a manutenção da figura 12 como ilustradora de um tempo geral do mundo.

A racionalidade humana opera de modo muito natural a tarefa de reestruturar recursivamente informações linguísticas de tempo, à medida que aparecem com o tempo. Essa naturalidade se dá por um princípio organizacional da linguagem, pois algo superficialmente complexo deve estar em harmonia também com interpretações em níveis 
mais profundos de organização da linguagem. Não deixa de ser notável o fato de a linguagem tecer o tempo em diferentes etapas, usando apenas as noções básicas de presente, passado e futuro. Apenas com essas três noções, mantemos, de modo geral, uma perfeita e imediata compreensão do sentido temporal linguístico. Mas percebemos que se torna impossível tentar descrever o tempo sem primeiramente distinguir os vários tipos de temporalidade da linguagem. Foi possível distinguir quatro tipos de interpretação do tempo linguístico, que identificamos como quatro níveis de tempo: o presente real do ato da comunicação; o presente lógico do discurso (MF), os sistemas de referência do tempo (MRs); o encadeamento dos eventos. Depois, passamos a investigar algumas teorias que explicavam o sistema do tempo linguístico sem termos como objetivo analisar exaustivamente cada uma delas. Pretendíamos ter uma visão geral de como algumas teorias descreviam os dois grandes sistemas temporais.

Percebemos que Weinrich possuía uma classificação muito intuitiva sobre as duas temporalidades do discurso - entendido como o mundo possível criado pela linguagem. Weinrich, entretanto, pretendia fazer uma classificação dos tempos verbais. Nós, por outro lado, partindo do pressuposto que o nosso sistema verbal quando somado a outras formas linguísticas de tempo, como os advérbios e marcas cronológicas, nos mostra um sistema temporal construído com grande complexidade e, por isso, muitas vezes os verbos ganham aparentemente outro valor de tempo. Isso é muito claro em língua portuguesa. Por esse motivo, nos preocupamos em classificar na língua portuguesa dois grandes grupos de lugares mentais de tempo, e não classificar dois grupos de formas verbais de tempo, que resultaria em sugerirmos que são estes os únicos responsáveis pela construção das duas grandes temporalidades.

Com o uso dos três construtos reichenbachianos, sob a nova leitura que fizemos, é possível descrever o contexto pragmático e enunciativo de uma sentença, reforçando a defesa de que há lugares mentais adequados para uma interpretação de tempos verbais que aparentemente poderiam estar sendo "simplificados".

Portanto, a questão do tempo precisa ser vista dentro de uma compreensão de linguagem no sentido lato e estrito. Num sentido estrito, investigamos a estrutura linguística que manifesta o tempo e percebemos que podem ocorrer "transposições" morfológicas de tempo, porque, embora possamos oferecer uma explicação pragmática e discursiva para a interpretação temporal de um dado enunciado, este ainda necessitará de uma classificação morfológica. E, num sentido lato, a questão do tempo na linguagem necessita do mundo real, das questões biológicas do mecanismo da linguagem e também do repertório histórico e cultural dos falantes para a interpretação do tempo. 
O produto da soma de todos os elementos temporais de um enunciado responsável pela formação de sua temporalidade mereceria um estudo mais cuidadoso. Há, principalmente na linguagem falada, construções de tempo estranhas num primeiro momento de análise, e conhecer os valores reais dos empregos linguísticos das formas que empregam a noção de tempo abriria caminho para deduzir a organização gramatical do sistema da língua.

Para formalizarmos a explicação do valor temporal de um enunciado, optamos por usar os construtos de Reichenbach, que acabaram sofrendo uma nova leitura: O Momento da Fala não é identificado em um enunciado apenas por um advérbio ou por uma marcação cronológica - como tem feito a tradição reichenbachiana; e o MR passa a ser o espaço mental aberto por elementos indicadores de tempo e também pelo valor temporal total do enunciado. Entendido dessa forma, a linha do tempo onde Reichenbach dispunha seus construtos ganha, na nossa descrição, uma bidirecionalidade, ou seja, duas direções. Defendemos também, na nossa leitura, que o Momento da Fala não poderia ser sempre um tempo presente em relação ao momento da enunciação; o MF é um presente em relação ao momento de referência criado na interlocução. Como o momento de referência aberto se torna uma distentio animi, ele é organicamente "presente" em relação ao momento da enunciação. Deste ponto de vista funcional da linguagem, o eixo zero da enunciação se corresponde ao eixo zero do MF.

No discurso resultante, há alguns lugares discursivos de tempo que foram criados na interlocução. O tempo do discurso funciona como um fator de intersubjetividade, e essa "condição de intersubjetividade é que torna possível a comunciação lingüística." (BENVENISTE, 2006, p.78).

Pudemos identificar seis lugares mentais de tempo, ou momentos de referência (MRs), onde dispomos os tempos gramaticais de cada evento (figura 61). Há seis momentos de referência porque são três fases do tempo e duas intenções para cada uma delas. Em outras palavras, o tempo interiorizado por nós é como se fosse uma linha do tempo dividida em três partes (um passado, um presente e um futuro), e, além disso, nós falantes possuímos duas intenções comunicativas quanto ao tempo: os interlocutores mantêm uma relação ora tensa ora distensa entre si, e uma das formas dessa marcação é o tempo (enunciativo ou enuncivo). Os espaços mentais abrirão um dos seis grandes lugares mentais para localizarmos temporalmente outros espaços mentais entendidos como pequenas parcelas de tempo ou "cenas". A abertura de espaços mentais pode se dar por space builders (construtores de espaço) que nos indicam um outro espaço mental, onde os verbos, por exemplo, podem receber um novo contexto de significação. É o falante, a depender de sua intenção, quem cria o sistema inercial ou MR. Como se percebeu, os estudos de tempo sob o ponto de vista de 
uma teoria linguística cognitiva poderiam contribuir melhor na explicação de muitos fenômenos.

A instalação online de um momento de referência, indicando um lugar temporal, demonstra uma natureza intersubjetiva do discurso, sem a qual o tempo linguístico não funcionaria.

É importante enfatizar, mais uma vez, que o texto produzido por um falante é apenas uma proposta de construção de sentido, uma ponta de iceberg. O sentido pleno, a parte maior e submersa do iceberg, tem de ser sempre construído dentro de uma situação discursiva de interlocução. (ABREU, 2010, p.13)

O sentido pleno do tempo, tendo como referência o sistema MR estabelecido na situação discursiva de interlocução, mostra-nos o que está permitindo construir as condições de verdade de um enunciado, a partir do significado de suas partes, uma vez que, neste momento, se estabelece as coordenadas espaçotemporais.

Se o sujeito da comunicação não tivesse certeza de que seu interlocutor, a cada ato de fala, também passaria com ele pelas "portas do tempo" que indicarão, do outro lado, qual o sistema de referência será adotado, ele - o sujeito - talvez não se comunicasse. 


\section{REFERÊNCIAS BIBLIOGRÁFICAS}

ABBAGNANO, Nicola. Dicionário de Filosofia. Trad. Alfredo Bosi. São Paulo: Mestre Jou, 1968. p.908-912.

ABREU, Antônio Suárez. Linguística Cognitiva: uma Visão Geral e Aplicada. São Paulo, 2010. No prelo.

ARANTES, Paulo Eduardo. A Espaço-temporalidade. In: Hegel - a ordem do tempo. São Paulo: Polis, 1981. p.17-26.

ARISTÓTELES. O Tempo. In: Física. Madrid: Gredos, 1998. p.264-291.

ASKIN, I. F. O Problema do Tempo: sua interpretação filosófica. Trad. Joel Silveira, Rio de Janeiro: Paz e Terra, 1969.

BACHELARD, Gaston. A dialética da duração. São Paulo: Ática, 1988.

BARROS, Diana Luz Pessoa de Barros. Teoria Semiótica do Texto. $4^{\mathrm{a}}$ ed. São Paulo: Ática, 2005.

BECHARA, Eli Nazareth. A Espaciotemporalidade Dêitica, Paradêitica, Pragmática e Mítica no Verbo da Língua Portuguesa. 1984. 197f. Tese (Doutorado em Letras) Faculdade de Ciências e Letras de Araraquara, 1984.

BECHARA, Evanildo. Moderna Gramática Portuguesa. Rio de Janeiro: Lucerna, 2004.

BENVENISTE, Émile. Problemas de Lingüística Geral I. $4^{\text {a }}$ edição. Trad. Maria da Glória Novak e Maria Luisa Neri. Campinas: Pontes, 1995.

Problemas de Lingüística Geral II. $2^{\mathrm{a}}$ edição. Trad. Eduardo Guimarães et al. Campinas: Pontes, 2006.

BERNSTEIN, Peter L. Desafio aos Deuses. A Facinante História do Risco. 20 a Ed. Trad. Ivo Korylowski: Rio de Janeiro: Elsevier, 1997.

BRAGUE, Rémi. O Tempo em Platão e Aristóteles. Trad. Nicolas Nyimi Campanário. São Paulo: Loyola, 2006.

CAGLiARI, Luiz Carlos (Org.) As Expressões do Tempo na Linguagem. Araraquara: Edição do Autor, 2007.

As Portas do Tempo. Campinas: UNICAMP-IEL, 1982. versão datilografada e cedida pelo autor. $13 \mathrm{f}$.

CAMMAROTA, Martins. O legado de Einstein para a física médica. Palestra da exposição Einstein, organizada pela Pesquisa FAPESP no Parque do Ibirapuera em São Paulo, 22/11/08. Disponível em: < http://www.revistapesquisa.fapesp.br/pdf/einstein > acesso em 10 set 2009. 
CASTILHO, A. T. Introdução ao Estudo do Aspecto Verbal na Lingua Portuguesa. Marília: F.F.C.L. de Marília, 1968.

CHOCIAY, Rogério Elpídio. Discurso e Reenunciação: uma leitura crítica. 1979. $174 f$. Dissertação (Mestrado em Letras) - Puc-Paraná, Curitiba, 1979.

CLARK, H. Space, Time, Semantics, and the Child. In: Timethy Moore (ed). Cognitive Development and the Acquisition of Language. New York: N.Y. Academic Press, 1973. p.27-64.

CLARKE, A. C. 2001: Uma odisséia espacial. Trad. Stella Alves de Souza. São Paulo: Expressão e Cultura, 1968.

CORÔA, Maria Luiza Monteiro Sales. O Tempo nos verbos do Português: uma introdução à sua interpretação semântica. Brasília: Thesaurus, 1985. 104p.

Unicamp, 1998.

. Tempo e Temporalidade na Língua. 1998. 270f. Tese (Doutorado em Letras)

CUNHA, C.; CINTRA, L. Nova Gramática do Português Contemporâneo. Rio de Janeiro: Nova Fronteira, 1985.

CUNHA, C. Gramática do Português Contemporâneo. Belo Horizonte: Bernardo Álvares, 1970.

JAPIASSÚ, H.; MARCONDES, D. Dicionário Básico de Filosofia. $2^{\mathrm{a}}$ ed. Rio de Janeiro: Jorge Zahar, 1989. p.233-234.

MORA, J. F. Dicionário de Filosofia. Trad. Roberto Leal Ferreira e Álvaro Cabral. São Paulo: Martins Fontes, 1994. v.2. p.671-685.

DINIZ, Maria Lúcia Vissotto Paiva. Semiótica e mídia: a proposta de integração do GESCom. In: _ _ PORTELA, Jean Cristtus (Org.). Semiótica e mídia: textos, práticas, estratégias. Bauru: UNESP/FAAC, 2008. p.11-12.

ECO, Umberto. Lector in fabula. Trad. Attilio Cancian. São Paulo: Editora Perspectiva, 1986.

BARSA Enciclopédia. Rio de Janeiro: Enciclopédia britânica editoras, São Paulo, v.13. 1965. p.201-202.

FAUCCONIER, Gilles; TURNER, Mark. The way we think: conceptual blending and the mind's hidden complexities. New York: Basic Books, 2002.

FAUCONNIER, Gilles. Espaces Mentaux. Paris: Les Édition de Minuit. 1984.

FÁVERO, L.L.; KOCH, I. G. V. Linguística Textual: Introdução. 5 Ed. São Paulo: Cortez, 2000 .

FERRARI, Lílian Vieira; ALONSO, Karen Sampaio Braga. Subjetividade e Construções de Futuro no Português Brasileiro. Alfa, Araraquara, v. 1, n.53, p223-241, 2009. 
FIORIN, José Luiz. Tempo e Temporalização. In: CAGLIARI, Luiz Carlos (org.) Tempo e Linguagem. São Paulo: Cultura Acadêmica Editora, 2008. v.1. p.9-39.

As Astúcias da Enunciação - As categorias de Pessoa, Espaço e Tempo. $2^{\mathrm{a}}$ edição. São Paulo: Ática, 2008.

Elementos de análise do discurso. $6^{\mathrm{a}}$ ed. São Paulo: Contexto, 1997. (Repensando a Língua Portuguesa).

. Pragmática. In:

(org.) Introdução à Lingüística II. Princípios de Análise. São Paulo: Contexto, 2003. v.2. p.160-185.

FLORES, et al. (Org.) Dicionário de Lingüística da Enunciação. São Paulo: Contexto, 2009.

FLORES, Valdir do Nascimento; TEIXEIRA, Marlene. Introdução à Lingüística da Enunciação. São Paulo: Contexto, 2005.

FONSECA, Fernanda Irene. Deixis, Tempo e Narração. Porto: Fundação Eng. António de Almeida, 1992.

. Gramática e Pragmática: Estudos de Lingüística Geral e de Lingüística Aplicada ao Ensino de Português. Porto: Porto, 1994. (Lingüística).

FREIRE, José Celio. Criar para o tempo. Tempo para o criar. Para criar o tempo. Uma revisitação da (ex)temporalidade na Recherche proustiana. Estudos de Psicologia, v.6 n.1, Natal, jan./jun. 2001. Disponível em: <www.sciel> acesso em 11 out. 2008.

FREITAG, R. M. K. Tempo na frase e tempo no texto: as teorias de Reichenbach e de Rojo e Veiga. Linguagem em (Dis)curso, v.5, n. 2, 2005, Disponível em: $<$ www3.unisul.br/paginas/ensino/pos/linguagem/0502/07.htm> acesso em 20 mar. 2010.

GIANNETTI, Eduardo. O valor do amanhã: ensaio dobre a natureza dos juros. São Paulo: Companhia das Letras, 2005.

GOLD, Stephen Jay. Seta do Tempo, Ciclo do Tempo: Mito e Metáfora na descoberta do Tempo Geológico. Trad. Carlos Afonso Malferrari. São Paulo: Companhia das Letras, 1991.

DELTA LAROUSSE Grande Enciclopédia. Rio de Janeiro: Editora Delta S. A. v.11, 1970. p.6605.

GREIMAS, A. J.; COURTÈS, J. Dicionário de Semiótica. Vários tradutores. São Paulo: Contexto, 2008.

GRIBBIN, John. Tempo: Profundo Mistério do Universo. $2^{\text {a }}$ ed. Trad. Aldo Boccine Neto. Rio de Janeiro: Francisco Alves, 1983.

HAWKING, Stephen W. Uma Breve História do Tempo: Do Big Bang aos Buracos Negros. Trad. Maria Helena Torres. São Paulo: Rocco/Círculo do Livro, [1989].

HJELMSLEV, Louis. Prolegômenos a uma teoria da linguagem. São Paulo: Perspectiva, 1975. 
HOLLANDA, Chico Buarque de. Estorvo. São Paulo: Companhia das Letras, 1991.

ILARI, Rodolfo. A Expressão do Tempo em Português. São Paulo: Contexto, 2001. (Repensando a Língua Portuguesa).

; GERALDI, João Wanderley. Semântica. São Paulo: Ática, 1985. (Série Princípios, n.8).

INTERNATIONAL Encyclopedia of the Social Sciences. The Macmillan Company \& The Free Press David L. Sills Editor, [1972]. v.16, p.25.

KANT, Immanuel. Parte primeira. Estética transcendental. In: Crítica da Razão Pura. São Paulo: Abril Cultural, 1983. p.39-55. (Os Pensadores, v.XXV).

KOCH, I.; TRAVAGLIA, L.C. A coerência textual. São Paulo: Contexto, 1990.

KOCH, Ingedore G. Villaça. Argumentação e linguagem. 6a . Ed. São Paulo: Courtez, 2000.

KÖVECSES, Zoltán. Constructing Meaning in Discouse - Mental Space. In: Language, mind, and culture: A Pratical Introduction. Oxford: Oxford University Press, 2006, p.249269.

LACEY, Hugh M. A linguagem do espaço e do tempo. Tradução: Marcos Barbosa de Oliveira. São Paulo: Perspectiva, 1972. (Série Debates-Filosofia).

LAKOFF, George; JOHNSON, Mark. Metaphors We Live By. Chicago: The University of Chicago Press, 1980.

LONGO, Beatriz Nunes de Oliveira. A auxiliaridade e a Expressão do tempo em português. Dissertação (Mestrado em Letras). FCL Araraquara, 1990.

LYONS, J. Linguagem e lingüística: Uma introdução. Trad. Marilda Winkler Averburg e Clarisse Sieckenius de Sousa. Rio de Janeiro: Guanabara, 1987.

Semântica. Trad. Wanda Ramos. Lisboa: Presença; Martins Fontes, 1977.

MACEDO, L. Piaget, Einstein e a noção de tempo na criança. Palestra proferida em 22/11/2008, como parte da programação cultural da exposição Einstein organizada pela Pesquisa FAPESP, (p.1-18) Edição Online 01/12/2008. Disponível em: < http://www.revistapesquisa.fapesp.br/pdf/einstein/lino.pdf > acesso em 10 set 2009.

MARICONDA, Pablo. De Galileu a Einstein: do tempo da física ao tempo vivido. Palestra da exposição Einstein, organizada pela Pesquisa FAPESP no Parque do Ibirapuera em São Paulo, 01/11/08. Disponível em: $<$ http://www.revistapesquisa.fapesp.br/pdf/einstein $>$ acesso em 10 set 2009.

MARQUES, Maria Helena Duarte. Iniciação à Semântica. 2a Ed. Rio de Janeiro: Zahar Editor, 1995.

MARTINS, Roberto. Espaço, tempo e éter, na teoria da relatividade. Palestra da exposição Einstein, organizada pela Pesquisa FAPESP no Parque do Ibirapuera em São Paulo, 18/10/08. Disponível em: < http://www.revistapesquisa.fapesp.br/pdf/einstein > acesso em 10 set 2009. 
MATHESON, Richard. Em algum lugar do Passado. Trad. Luísa Ibañez. São Paulo: Nova Cultura, 1987.

MOLHO, M. Sistemática del Verbo Español. Madrid: Gredos, 1975.

MÜLLER, Ana Lúcia de Paula; VIOTTI, Evani de Carvalho. Semântica Formal. In: FIORIN, José Luiz (Org). Introdução à Lingüística II: Princípios de Análise. São Paulo: Contexto, 2003. p.137-159.

PARRET, H. Enunciação e Pragmática. Campinas: Editora da Unicamp, 1988.

PEÑA, M. Sandra. Dependency systems for image-schematic patterns in a usage-based approach to language. Journal of Pragmatics, n.40, p.1041-1066, 2008.

PERLS, Fritz. A Abordagem gestáltica e testemunha ocular da terapia. $2^{\mathrm{a}}$ ed., Rio de Janeiro: Livros Técnicos e científicos Editora S. A., 1988.

PIAGET, J. Seis Estudos de Psicologia. Trad. M.A.A. D'Amorin e P.S.L. Silveira. Rio de Janeiro: Forense, 1969.

A Construção do Real na Criança. Trad. Álvaro Cabral. $2^{\mathrm{a}}$ ed. Rio de Janeiro: Zahar, 1975. p.298-325.

Forense, 1973.

Problemas de Psicologia Genética. Trad. Célia E. A. Di Piero, Rio de Janeiro:

PIETROFORTE, Antonio Vicente Seraphim; LOPES, Ivã Carlos. A semântica lexical. In:

FIORIN, José Luiz (Org). Introdução à Lingüística II: Princípios de Análise. São Paulo: Contexto, 2003. p.111-135.

PINTO, Beatriz Virgínia Camarinha Castilho. Narratividade e Representação da Temporalidade no Interrogatório Judicial. Anais do SETA. v.2, p.409-415, 2008.

PONTES-RIBEIRO, Dulce Helena. O Tempo (cronos) e os tempos verbais. Transformar, Itaperuna, v.5, p.25-35, novembro, 2007.

PRIGOGINE, Ilya. O Fim das Certezas: Tempo, Caos e as Leis da Natureza. Trad. Roberto Leal Ferreira. São Paulo: Unesp, 1996.

O Nascimento do Tempo. Lisboa: Edições 70, 1999.

PROUST, Marcel. No caminho de Swann. Trad. Mário Quintana. São Paulo: Abril Cultural, 1979.

RAY, Chistopher. Tempo, Espaço e Filosofia. Trad. Thelma Médice Nóbrega. São Paulo: Papiros, 1993.

RÉE, Jonathan. Heidegger. São Paulo: Unesp, 2000.

REICHENBACH, Hans. Elements of symbolic logic. New York: Colier-MacMillan, 1966.

REIS, Carlos; LOPES, Ana Cristina M. Dicionário de Narratologia. $7^{\text {a }}$ Edição. Coimbra: Almedina, 2000. 
RICOEUR. P.; LARRE, C.; PANIKKAR, R. et al. As culturas e o Tempo. Trad. Gentil Titton, Orlando dos Reis e Ephraim Ferreira Alves. Petrópolis: Vozes; São Paulo: EDUSP, 1975.

SANTO AGOSTINHO. O Homem e o Tempo. In: Confissões. São Paulo: Abril, 1973. p.243255. (Os Pensadores, v.VI).

SILVA, Ademar da. A expressão da futuridade no português falado. Araraquara: UNESP, FCL, Laboratório Editorial; São Paulo: Cultura Acadêmica Editora, 2002.

THE ENCYCLOPEDIA of Philosophy. New York: The Macmillan Company \& The Free Press, [1967]. v.8. p.126.

TURNER, Mark. The Literary mind: the origins of thought and language. Oxford: Oxford University Press, 1996.

ULLMAN Stephen. Semântica: Uma Introdução à Ciência do Significado. Lisboa: Fundação Calouste Gulbenkian, 1968.

WEINRICH, H. Estructura y función de los tiempos en el lenguaje. Trad. Federico Latorre. Madrid: Editorial Gredos, 1968.

Le temps. Le récit et le commentaire. Paris: Seuil, 1989

WHITROW, G. J. O Tempo na História: Concepções do Tempo da Pré-História aos Nossos Dias. Trad. Maria Tereza X. e A. Borges. Rio de Janeiro: Jorge Zahar, 1993. (Ciência e Cultura). 